\author{
UNIVERSIDADE DE SÃO PAULO \\ FACULDADE DE EDUCAÇÃO \\ PÓS-GRADUAÇÃO EM EDUCAÇÃ̃o \\ ÁREA: ESTADO, SOCIEDADE E EDUCAÇÃO
}

\title{
A TRAJETÓRIA DO PROJETO CIEJA ENTRE AS POLÍTICAS PÚBliCAS DE EJA NA CIDADE DE SÃO PAULO
}

VANESSA ELSAS PORFÍRIO DE FARIA

São Paulo

2014 
Autorizo a reprodução e divulgação total ou parcial deste trabalho, por qualquer meio convencional ou eletrônico, para fins de estudo e pesquisa, desde que citada a fonte.

Catalogação na Publicação

Serviço de Biblioteca e Documentação

Faculdade de Educação da Universidade de São Paulo

374(81.61) Faria, Vanessa Elsas Porfirio de

F224t A trajetória do projeto CIEJA entre as políticas públicas de EJA na cidade de São Paulo / Vanessa Elsas Porfírio de Faria; orientação Maria Clara Di Pierro. São Paulo : s.n., 2014.

$157 \mathrm{p}$.

Dissertação (Mestrado - Programa de Pós-Graduação em Educação. Área de Concentração : Estado, Sociedade e Educação) - Faculdade de Educação da Universidade de São Paulo)

1. Educação de jovens e adultos - São Paulo - 2001-2009 2. Políticas públicas 3. Democratização do ensino 4. Participação I. Di Pierro, Maria Clara, orient. 
Nome: ELSAS, Vanessa Porfírio de Faria

Título: A trajetória do Projeto CIEJA entre as políticas públicas de EJA na cidade de São Paulo

Dissertação apresentada à Faculdade de Educação da Universidade de São Paulo para obtenção do Título de Mestre em Educação.

Área de concentração: Estado, Sociedade E Educação

Orientadora: Prof $^{\mathrm{a}} \mathrm{Dr}^{\mathrm{a}}$ Maria Clara Di Pierro

Aprovado em:

Banca Examinadora

Prof. Dr. Instituição:

Julgamento: Assinatura:

Prof. Dr. Instituição:

Julgamento: Assinatura:

Prof. Dr. Instituição:

Julgamento: Assinatura: 
Dedico este trabalho aos estudantes e companheiros dos CIEJAs Butantã e Campo Limpo, que me ensinaram a ensinar e a aprender coletivamente, que me animaram a prosseguir na luta pelo direito à educação e pela felicidade na vida presente. 
Agradeço aos meus pais, Maria Therezia Elsas e Mario Luis Porfírio de Faria, por me ensinarem que a educação transforma vidas, por insistirem e me apoiarem em assim transformar as nossas.

Gratidão à Profa. Dra. Maria Clara Di Pierro, por compartilhar conhecimentos enriquecedores, pelo incentivo, pela compreensão e paciência com minhas limitações. Agradeço pelo exemplo e compromisso com a educação de jovens e adultos, que me orientaram a prosseguir.

Agradeço à Profa. Dra. Marília Spósito e aos colegas da pós-graduação que realizaram leituras generosas e me auxiliaram a desenhar o projeto de pesquisa.

Gratidão aos meus avôs Antônio Porfírio de Faria e Harry Elsas e minhas avós Therezinha de Oliveira Faria e Cacilda Elsas, que me encantaram pelos saberes e sabores dos livros, da arte, da terra e da convivência com a gente ao redor. À minha irmã, Mariana, e ao meu sobrinho, Victor, por compreenderem meus isolamentos e me conectarem com a alegria do cotidiano.

Agradeço também aos amigos, especialmente, Célia Aparecida Felipe Borges, Ana Célia Carvalho, Cristina da Silva Ferreira, Roseli Aparecida Pereira, Jorge Artur dos Santos, Laura Cymbalista, Renata Lopes de Oliveira, Aline Novais de Almeida, Isabel Kimie, Alexandre Franzin e Sander Joner, pelo compromisso com a educação, pelos ombros que descansaram minhas angústias e me empurraram para frente.

Gratidão imensa a todos que contribuíram para que eu pudesse ouvir e contar um pouco da história presente e para que ela se erguesse diariamente nos CIEJAs. 


\section{Mãos Dadas}

(Carlos Drummond de Andrade)

Não serei o poeta de um mundo caduco.

Também não cantarei o mundo futuro.

Estou preso à vida e olho meus companheiros.

Estão taciturnos, mas nutrem grandes esperanças.

Entre eles, considero a enorme realidade.

O presente é tão grande, não nos afastemos.

Não nos afastemos muito, vamos de mãos dadas.

Não serei o cantor de uma mulher, de uma história,

não direi os suspiros ao anoitecer, a paisagem vista da janela,

não distribuirei entorpecentes ou cartas de suicida,

não fugirei para as ilhas nem serei raptado por serafins.

O tempo é a minha matéria, o tempo presente, os homens presentes, a vida presente. 


\section{RESUMO}

ELSAS, Vanessa Porfírio de Faria. A trajetória do Projeto CIEJA entre as políticas públicas de EJA na cidade de São Paulo. 2014. 160 f. Dissertação (Mestrado) - Faculdade de Educação, Universidade de São Paulo, São Paulo, 2014.

A pesquisa sistematizou e analisou a trajetória do Projeto Centro Integrado de Educação de Jovens e Adultos (CIEJA). O objetivo foi compreender como foi constituído o modelo de organização escolar do CIEJA entre diferentes governos municipais e políticas públicas de Educação de Jovens e Adultos (EJA) de 2001 a 2009 na cidade de São Paulo. Realizou-se a pesquisa documental e entrevistas com técnicos educacionais, gestores e professores para apreender os momentos decisivos para a elaboração e reformulação do Projeto, utilizando-se como ferramenta de análise o Modelo de Múltiplos Fluxos de John Kingdon (2003) sobre a configuração dos problemas, soluções e contexto político que marcaram o desenho dos CIEJAs. Verificou-se que o Projeto CIEJA apresenta avanços consideráveis para a democratização do acesso à educação e o favorecimento da permanência dos jovens adultos e idosos nos estudos. Concluiu-se que a participação ativa dos gestores e professores dos CIEJAs foi decisiva para defender ou bloquear diferentes concepções de EJA e propostas políticas para modalidade ao longo do tempo, sobretudo nos momentos de transição entre os governos. Foi a participação e apropriação do modelo escolar dos Centros por esses profissionais que garantiram a sobrevivência dos CIEJAs e conduziram à sua regulamentação em Lei em 2012. Aponta-se, portanto, a necessidade de fortalecer a gestão democrática da educação, possibilitando a constituição de políticas públicas de EJA participativas, a partir dos saberes e vivências dos trabalhadores da educação, estudantes e comunidade escolar.

Palavras-chaves: educação de jovens e adultos; CIEJA, políticas públicas; participação; gestão democrática. 


\begin{abstract}
ELSAS, Vanessa Porfírio de Faria. The trajectory of the Project CIEJA among the public policies for youth and adult education in the city of São Paulo. 2014. 160 f. Dissertação (Mestrado) - Faculdade de Educação, Universidade de São Paulo, São Paulo, 2014.

The research has organized and analyzed the trajectory of the Project CIEJA among the public policies for youth and adult education in the city of São Paulo. The objective was to capture which elements have favored the Project's idealization and continuity of its schooling organization model between different municipal governments, from 2001 to 2009. It was held a documental research and interviews to capture the decisive moments in the project's elaboration and reformulation, using as an analysis tool the Multiple Streams Model of John Kingdon (2003). It was verified that the Project CIEJA has presented substantial advances for the democratization of education access and to promote chances for youth and adults to keep on their studies. It concluded that the active participation of CIEJA's managers and teachers was crucial to defend or block different educational conceptions and political proposals for the youth and adults education over time, especially among government changes. It was the school professional participation that ensured the CIEJAs survival and conducted to its regulation Law in 2012. It has been observed, therefore, the need to reinforce the democratic management on the education field, enabling the constitution of participative educacional public policies, considering the knowledge and life experiences of the education workers, students and school comunity.
\end{abstract}

Key-words: Youth and Adult education, educational public policies, participation, democratic management. 


\section{LISTA DE SIGLAS}

CEDI Centro Ecumênico de Documentação e Informação

CEMES Centros Municipais de Ensino Supletivo

CEPIS Centro de Educação Popular do Instituto Sedes

CIEJA Centro Integrado de Educação de Jovens e Adultos

CIESP Centro das Indústrias do Estado de São Paulo

CMCT Centro Municipal de Capacitação e Treinamento

CME Conselho Municipal de Educação

CNE Conselho Nacional de Educação

CONFINTEA Conferência Internacional de Educação de Jovens e Adultos

CRECE Conselho Regional de Conselhos Escolares

DEM Partido Democratas

DOT Diretoria de Orientações Técnicas

EDA Programa de Educação de Adultos

EJA Educação de jovens e adultos

EMEF Escola Municipal de Ensino Fundamental

EMEFM Escola Municipal de Ensino Fundamental e Médio

EMES Escolas de Ensino Supletivo

FIESP Federação das Indústrias do Estado de São Paulo

FUNDEB Fundo de Manutenção e Desenvolvimento da Educação Básica e de Valorização dos Profissionais da Educação

FUNDEF Fundo de Manutenção e Desenvolvimento do Ensino Fundamental e de Valorização do Magistério

IBGE Instituto Brasileiro de Geografia e Estatística

JBD Jornada Básica Docente

JEIF Jornada Especial Integral de Formação

MOBRAL Movimento Brasileiro de Alfabetização

MOVA Movimento de Alfabetização

NAEs Núcleos de Ação Educativa

PDS Partido Democrático Social

PP Partido Progressista Brasileiro

ProAlfa Programa de Alfabetização de Adultos

PSDB Partido da Social Democracia Brasileira

PT Partido dos Trabalhadores

PTB Partido Trabalhista Brasileiro

SEBES Secretaria do Bem-Estar Social

SENAC Serviço nacional de aprendizagem comercial

SENAI Serviço Nacional da Aprendizagem Industrial

SESI Serviço Social da Indústria

SINPEEM Sindicato dos Profissionais da Educação do Ensino Municipal 


\section{Lista de Tabelas}

Tabela 1 - População Total e Analfabeta de 15 Anos e Mais e Taxa de Analfabetismo no de São Paulo, Subprefeituras e Distritos Municipais 2000 e 2010.

Tabela 2 - Evolução das Matrículas ${ }^{1}$ no Ensino Fundamental de Jovens e Adultos por Dependência Administrativa no Município de São Paulo (2000/2012).

Tabela 3 - Evolução do número de matrículas em CIEJAs e EMEFs (2003/2012) p.18

Tabela 4 - Evolução de Matrículas na EJA entre 1989 e 1992. p.59

Tabela 5 - Porcentagem de estudantes de EJA segundo gênero e faixa etária, 1989. .p. 100

Tabela 6 - Estudantes dos CEMES segundo gênero e faixa etária - 2002 p. 101

Tabela 7- Número de alunos por faixa etária nos CIEJAs em 2013. .p. 103

Tabela 8- Alunos dos CEMES ocupados segundo o setor de atividade. p.106

Tabela 9 - Profissão dos estudantes de Suplência I em 1989 p. 107

Tabela 10 - Matrícula de estudantes com necessidades educacionais especiais no Ensino Fundamental/ EJA Total (Inclusão). p. 108

\footnotetext{
${ }^{1} \mathrm{O}$ número de matrículas, baseado nas fontes citadas nessa tabela, divergem dos números apresentados pelo Relatório Anual de Fiscalização do Tribunal de Contas do Município em 2009, o qual aponta menos matrículas entre 2006 e 2009, baseado no Relatório de Dados Gerenciais SME-ATP/CI.
} 


\section{SUMÁRIO}

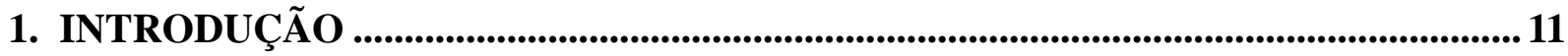

1.1 Contexto, justificativa, objetivos e hipóteses de pesquisa .........................................12

1.2_Os Centros Integrados de Educação de Jovens e Adultos .................................................21

1.3 Etapas da pesquisa e referencial teórico-metodológico.....................................................24

1.3.1 Considerações sobre as concepções de EJA ..............................................................26

1.3.2 Considerações sobre a gestão democrática do ensino público...................................32

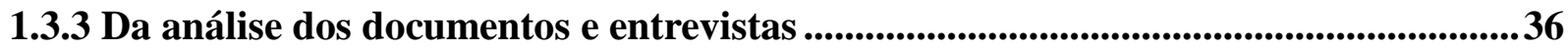

1.3.4 A análise de políticas públicas e o Modelo de Múltiplos Fluxos .....................................40

2. POLÍTICAS PÚBLICAS DE EJA EM SÃO PAULO_..........................................47

2.1 Gestão de Luíza Erundina (PT) - de 1989 a 1993 ......................................................48

2.2 Gestão de Paulo Maluf (PP) e de Celso Pitta (PP) - de 1993 a 2000..............................60

2.3 A gestão de Marta Suplicy (PT) e a idealização do CIEJA (2001-2004) .........................68

2.4 Gestão de José Serra (PSDB) e Gilberto Kassab (DEM) (2005-2008) .............................86

3. OS SUJEITOS E O MODELO DE ORGANIZAÇÃO ESCOLAR DOS CIEJAS .......99

3.1 O Perfil dos Educandos........................................................................................99

3.2 O modelo de organização escolar CIEJA: tempo, currículo e espaço .......................... 111

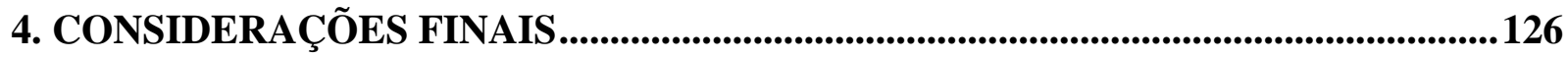

5. REFERÊNCIAS BIBLIOGRÁFICAS .....................................................................138

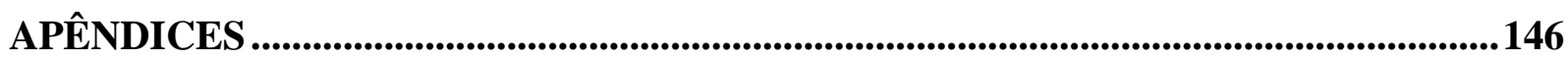

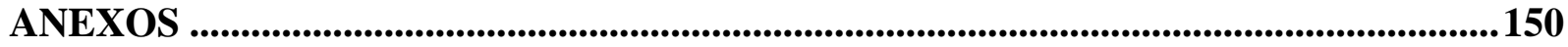




\section{INTRODUÇÃO}

A motivação para realizar essa pesquisa se deve, em grande parte, à minha vivência como professora de jovens, adultos e idosos desde a graduação em Letras. Em minhas primeiras experiências como educadora num grupo comunitário de alfabetização de adultos, pertencente à Pastoral Educação e Esperança no litoral sul de São Paulo, experimentei diferentes possibilidades em organizar o trabalho pedagógico para pequenas turmas. Convivíamos com as dificuldades de conseguir recursos básicos para desenvolvimento das atividades, como espaço fixo e materiais didáticos. Acumulei, assim, inquietações sobre como desenvolver práticas educativas significativas e sobre a carência de iniciativas mais abrangentes voltadas à população com pouca ou nenhuma escolaridade.

Mais tarde, passaria a trabalhar ao mesmo tempo em escolas públicas do Estado e em organizações do terceiro setor como professora de Português de adolescentes. Vivenciava, por um lado, o modelo escolar tradicional, que alcançava grande quantidade de estudantes em lógicas rígidas de tempo, espaço e currículo que, muitas vezes, pareciam limitar minha atuação; de outro, projetos com grupos pequenos, que buscavam soluções para o que consideravam lacunas da escolarização dos jovens e esperavam de mim respostas sobre como superá-las.

Com meu ingresso como professora no município de São Paulo em 2008, assumi o cargo de Professora de Português no período noturno do Ensino Fundamental, atuando como uma espécie de professora substituta nas salas de EJA, professora em "módulo"2. Era difícil prever as turmas para quem daria aulas a cada dia, o tempo de planejamento de atividades em parceria com meus colegas era escasso e, na maioria das vezes, inexistente. Se a iniciativa pública para educação de jovens, adultos e idosos se concretizava ali, testemunhava a precariedade nas condições de ensino e de aprendizagem, que resultava no esvaziamento das turmas ao longo do ano. O sentido de minha atuação na rede municipal, assim, aos poucos também se esvaziava. Por esse motivo, optei por me inscrever em um processo seletivo da própria rede para participar de outra proposta educativa para EJA: o Centro Integrado de

\footnotetext{
${ }^{2}$ Refiro-me ao módulo de professores sem regência de classes que ministram aulas na ausência do regente.
} 
Educação de Jovens e Adultos (CIEJA).

Meu trabalho como professora do CIEJA Butantã, de 2009 a 2013, despertou diversos olhares para esse Centro: primeiro, o misto de "estranhamento" e encantamento, depois a curiosidade e inquietação sobre como fora possível construir aquela "escola diferente", como citavam frequentemente os estudantes e como eu mesma podia constatar. Lá, as aulas tinham duração de duas horas e quinze minutos, os alunos podiam frequentá-las em seis horários diferentes durante o dia, o portão estava sempre aberto, não se fechava diante de atrasos, não havia professores em módulo e nem turmas sem professores. Era possível ter maior proximidade com os educandos, refletir sobre o currículo e planejar as atividades dialogando todas as semanas com todos os colegas. Nessa iniciativa pública de educação de jovens e adultos pude experimentar, em certa medida, aquela liberdade de organizar o trabalho pedagógico coletivamente que eu vivenciara, até então, apenas em práticas educativas desenvolvidas fora das escolas.

O questionamento sobre aquela experiência se ampliava na medida em que eu era também educada pela interação com alunos e colegas, por nossa atuação diante dos desafios e acontecimentos intra e extraescolares. Muitos deles já eram conhecidos, como as dificuldades dos educandos conciliarem os estudos com as responsabilidades familiares e o trabalho. Outros eram novos: as constantes reivindicações discentes pela oferta do Ensino Médio no CIEJA, os receios de que houvesse alguma modificação no projeto em que baseávamos o funcionamento do Centro, as comissões de professores para justificar ou apresentar nossa forma de trabalhar perante os órgãos de gestão e normatização do ensino municipal. Nesse período, eu também ia descobrindo que não estávamos isolados, mas compartilhávamos as experiências com outras unidades de CIEJA em São Paulo que, mesmo baseadas em um mesmo projeto, tinham também suas particularidades.

Assim, decidi voltar aos estudos para ampliar o olhar sobre aquela realidade e compreender que espaços na formulação das políticas e propostas educativas estariam abertos aos profissionais das escolas para criarem e manterem outra forma de fazer a EJA na cidade.

\subsection{Contexto, justificativa, objetivos e hipóteses de pesquisa}

“As leis não bastam. Os lírios não nascem da lei.”. (Carlos Drummond de Andrade, 1992)

A Educação de Jovens e Adultos (EJA) é um direito consolidado na Declaração 
Universal dos Direitos Humanos (1948) no artigo XXVI: "Toda pessoa tem direito à instrução. A instrução será gratuita, pelo menos nos graus elementares e fundamentais". Também é reconhecida pela Carta Magna de 1988, em que o artigo 208, modificado pela Emenda 59 em2009, estabelece o dever do Estado garantir: "I - educação básica obrigatória e gratuita dos 4 (quatro) aos 17 (dezessete) anos de idade, assegurada inclusive sua oferta gratuita para todos os que a ela não tiveram acesso na idade própria".

Nosso trabalho se inscreve na vertente de estudos que tratam da EJA a partir do direito à educação (BEISIEGEL, 1974; GÓES, 1980; PAIVA, 1983; BRANDÃO, 1984; DI PIERRO, 2001; FÁVERO, 2006; HADDAD, 2007; GADOTTI, 2009). A abordagem da história da EJA e sua reafirmação como direito nas pesquisas não são meras coincidências, nem se limitam ao diálogo entre elas, mas são reflexo da luta para concebê-la como campo de responsabilidade pública (ARROYO, 2005).

Se os lírios não nascem da lei, como escreveu Drummond, tampouco ela nasce sem conflitos ou desafios de uma época, nem basta a lei para concretizar a educação para todos. São necessárias ações que a concretizem, políticas que a assegurem em consonância com as necessidades dos sujeitos e seu contexto. Relegada a políticas e financiamentos inconstantes, a EJA tem sido concebida à margem das ações educativas dirigidas aos infantes e adolescentes (DI PIERRO, 2008).

Depois de quinze anos de vagarosa queda, em 2012 a taxa de 8,7\% de pessoas analfabetas com quinze anos ou mais no Brasil apresentou um aumento em relação ao ano anterior, em que chegara a 8,6\% (IBGE, 2012). Esse fato não se repetia desde 1997, logo após a promulgação da Lei de Diretrizes e Bases 9.394 de 1996 e da Emenda Constitucional no 14 , que instituiu o Fundo de Manutenção e Desenvolvimento do Ensino Fundamental e de Valorização do Magistério (Fundef, Lei $n^{\circ}$ 9424/96). O Fundo orientava a focalização de recursos para a educação das crianças de 7 a 14 anos, conforme recomendações do Banco Mundial.

Dez anos depois, com a criação do Fundo de Manutenção e Desenvolvimento da Educação Básica e de Valorização dos Profissionais da Educação (FUNDEB), progressivamente as matrículas de EJA foram incorporadas, ainda que com valor inferior ao destinado aos estudantes do Ensino Fundamental ${ }^{3}$. Esperava-se que o novo fundo induzisse o

\footnotetext{
${ }^{3}$ Cada matrícula na modalidade EJA corresponde a 80\% do custo/aluno do Ensino Fundamental.
} 
aumento de matrículas na modalidade, mas têm sido constatadas quedas consideráveis (DI PIERRO; XIMENES, 2011, p. 6).

O número de pessoas, com 15 anos ou mais, consideradas analfabetas em São Paulo também revela o paradoxo: a cidade mais rica do Brasil ainda liderava, em 2010, o ranking dos municípios com maior quantidade de jovens e adultos que não sabiam ler ou escrever.

Os dados dos Censos Demográficos de 2000 e 2010 embora indiquem uma redução das taxas de analfabetismo na cidade, menores que em outros municípios brasileiros, também apresentam uma considerável parcela da população a quem o direito à educação ainda não foi efetivado: 281.847 pessoas.

\section{Tabela 1 - População Total e Analfabeta de 15 Anos e Mais e Taxa de Analfabetismo Município de São Paulo, Subprefeituras e Distritos Municipais 2000 e 2010}

\begin{tabular}{|c|c|c|c|c|c|c|}
\hline \multirow[b]{2}{*}{ Unidades Territoriais } & \multicolumn{2}{|c|}{ Total } & \multicolumn{2}{|c|}{ Analfabetos } & \multicolumn{2}{|c|}{$\begin{array}{c}\text { Taxa de } \\
\text { Analfabetismo }(\%)\end{array}$} \\
\hline & 2000 & 2010 & 2000 & 2010 & 2000 & 2010 \\
\hline Município de São Paulo & 7.841 .865 & 8.916 .518 & 354.049 & 281.847 & 4,5 & 3,2 \\
\hline Aricanduva/Formosa/ Carrão & 210.046 & 221.115 & 6.976 & 4.179 & 3,3 & 1,9 \\
\hline Butantã & 288.901 & 345.838 & 11.643 & 9.557 & 4 & 2,8 \\
\hline Campo Limpo & 360.805 & 459.787 & 22.793 & 19.312 & 6,3 & 4,2 \\
\hline Capela do Socorro & 399.614 & 450.503 & 24.646 & 21.700 & 6,2 & 4,8 \\
\hline Casa Verde/Cachoeirinha & 234.604 & 245.113 & 10.651 & 7.165 & 4,5 & 2,9 \\
\hline Cidade Ademar & 265.656 & 314.553 & 16.624 & 14.239 & 6,3 & 4,5 \\
\hline Cidade Tiradentes & 127.577 & 152.589 & 6.593 & 6.485 & 5,2 & 4,2 \\
\hline Ermelino Matarazzo & 152.709 & 163.174 & 7.259 & 5.237 & 4,8 & 3,2 \\
\hline Freguesia/Brasilândia & 284.042 & 313.018 & 15.540 & 11.411 & 5,5 & 3,6 \\
\hline Guaianases & 173.886 & 198.971 & 12.998 & 10.008 & 7,5 & 5 \\
\hline Ipiranga & 333.270 & 377.169 & 12.696 & 8.993 & 3,8 & 2,4 \\
\hline Itaim Paulista & 247.784 & 279.578 & 15.897 & 12.925 & 6,4 & 4,6 \\
\hline Itaquera & 356.094 & 403.963 & 16.445 & 13.647 & 4,6 & 3,4 \\
\hline Jabaquara & 164.360 & 181.251 & 7.214 & 5.430 & 4,4 & 3 \\
\hline Jaçanã/Tremembé & 188.480 & 226.477 & 10.152 & 9.037 & 5,4 & 4 \\
\hline Lapa & 224.115 & 259.298 & 4.997 & 3.872 & 2,2 & 1,5 \\
\hline M'Boi Mirim & 340.817 & 420.118 & 23.263 & 20.389 & 6,8 & 4,9 \\
\hline Mooca & 253.423 & 290.418 & 5.727 & 4.086 & 2,3 & 1,4 \\
\hline Parelheiros & 73.481 & 101.004 & 6.471 & 6.215 & 8,8 & 6,2 \\
\hline Penha & 367.873 & 385.502 & 12.884 & 8.526 & 3,5 & 2,2 \\
\hline Perus & 74.931 & 108.473 & 4.873 & 5.157 & 6,5 & 4,8 \\
\hline Pinheiros & 237.144 & 257.065 & 2.166 & 1.141 & 0,9 & 0,4 \\
\hline Pirituba & 289.538 & 342.009 & 12.473 & 11.494 & 4,3 & 3,4 \\
\hline Santana/Tucuruvi & 265.393 & 274.821 & 6.566 & 3.031 & 2,5 & 1,1 \\
\hline Santo Amaro & 179.162 & 200.580 & 3.412 & 2.015 & 1,9 & 1 \\
\hline
\end{tabular}


(continuação)

Taxa de

Total Analfabetos Analfabetismo (\%)

\begin{tabular}{lcccccc}
\multicolumn{1}{c}{ Unidades Territoriais } & 2000 & 2010 & 2000 & 2010 & 2000 & 2010 \\
\hline São Mateus & 269.503 & 321.639 & 15.982 & 14.521 & 5,9 & 4,5 \\
São Miguel & 265.593 & 281.156 & 18.087 & 13.246 & 6,8 & 4,7 \\
Sé & 316.985 & 374.954 & 6.090 & 4.630 & 1,9 & 1,2 \\
Vila Maria/Vila Guilherme & 235.027 & 239.533 & 10.893 & 7.226 & 4,6 & 3 \\
Vila Mariana & 266.955 & 302.935 & 3.029 & 1.804 & 1,1 & 0,6 \\
Vila Prudente/Sapopemba & 394.097 & 423.913 & 19.009 & 15.169 & 4,8 & 3,6 \\
\hline
\end{tabular}

Fonte: Infocidade, PMSP, elaborado com base nos Censos 2000 e 2010 do IBGE.

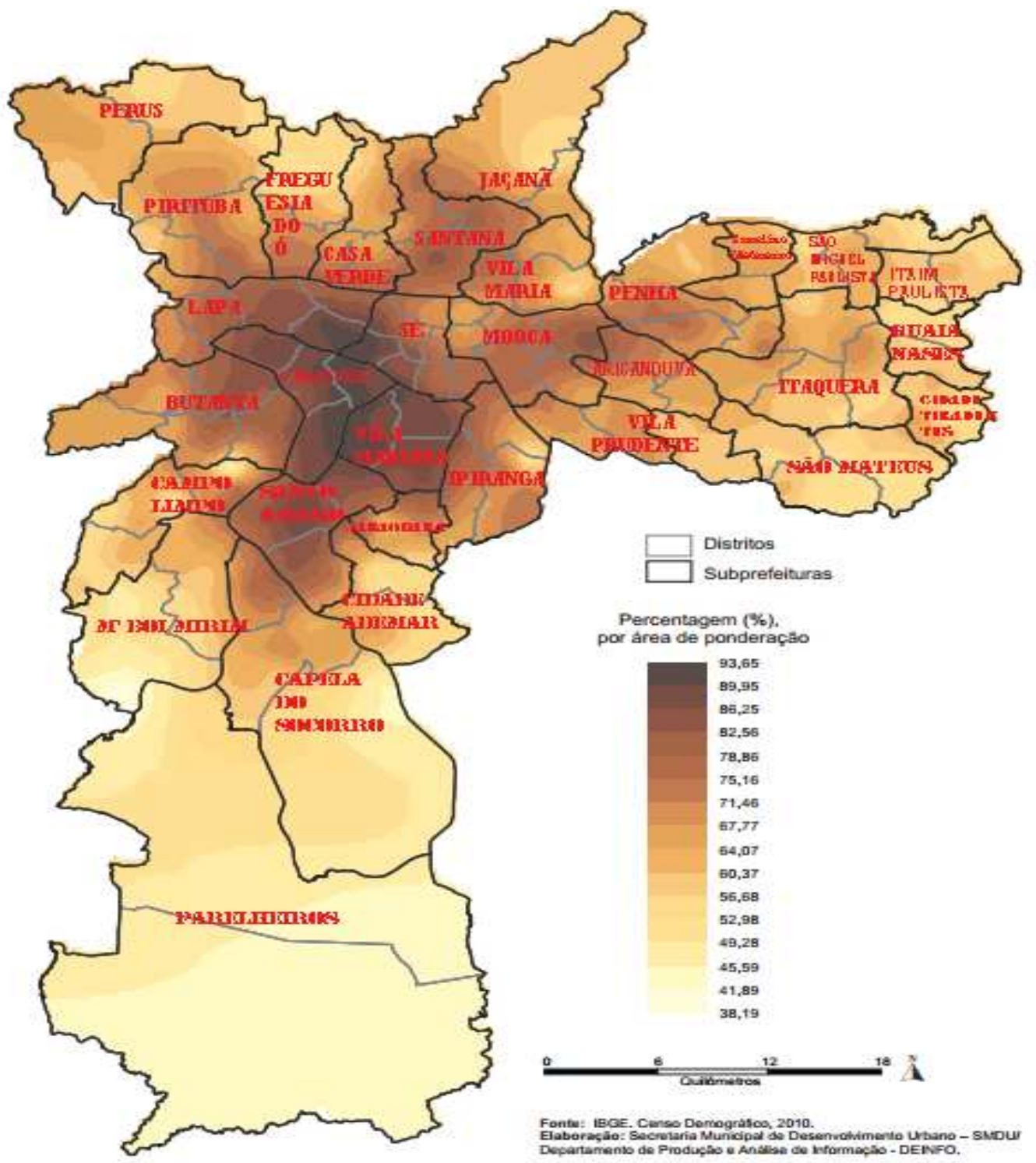

Mapa 1- São Paulo: População de 15 anos e mais com Ensino Fundamental completo 
Nota-se que as periferias concentram as maiores taxas de analfabetismo, associadas a outras formas de exclusão (Tabela 1). A maior quantidade de equipamentos culturais e de serviços públicos essenciais está nas zonas centrais, onde também encontramos maior renda per capita, taxa de empregos (GRINKRAUT et. al., 2013, p.35) e proporção de pessoas com mais de quinze anos que concluíram o Ensino Fundamental. Esses fatores marcam o mapa das desigualdades no município de São Paulo.

De acordo com Sergio Haddad (2008, p. 7), "a ausência de políticas efetivas de combate às desigualdades sociais acaba comprometendo os ideais igualitários do discurso político da educação pública”. Assim, as políticas educacionais para jovens, adultos e idosos necessitam não apenas ampliar as possibilidades desses sujeitos se tornarem estudantes, mas reconhecer e propiciar mudanças em sua (sobre)vivência como cidadãos.

Os jovens, adultos e idosos que ingressam no ensino básico ainda encontram desafios de permanecer nos cursos. Daqueles que frequentaram a EJA em 2007 no Brasil, 42,7\% não concluíram os estudos; destacamos $27,9 \%$ os abandonaram por não conciliá-los com os horários de trabalho ou de procurar trabalho e 15,6\% pela falta de interesse (IBGE, 2009).

Confirma-se, portanto, que para além da democratização do acesso à educação, é necessário verificar como as políticas públicas de EJA engendram "oportunidades educacionais apropriadas, consideradas as características do alunado, seus interesses, condições de vida e de trabalho", conforme postula a Lei Nacional de Diretrizes e Bases de 1996 (LDB 9.394/96).

A intensificação da municipalização da EJA, propiciada pelos dispositivos constitucionais de 1988 e da LDB de 1996, coloca-se de maneira ambígua no cenário nacional. Se por um lado ela pode fortalecer a participação da comunidade escolar na construção de uma escola democrática, mais aproximada às demandas dos educandos, por outro lado pode favorecer o aprofundamento das desigualdades entre as oportunidades educacionais dos municípios (DI PIERRO, 2005).

Nas últimas décadas, ao lado de propostas educativas municipais retrógradas e ainda baseadas no modelo das escolas para crianças, foram reveladas variadas experiências que apontam a emergência de novo paradigma nos modos de fazer a EJA, "olhando para os sujeitos concretos que participam dos programas, procurando construir estruturas e lógicas inovadoras que permitam incorporá-los em processos que sejam inclusivos e não repitam a 
tradição dos sistemas regulares" (HADDAD, 2007, p. 18).

Haddad (2007) organizou análises sobre programas e projetos de 125 municípios, concluindo que 'essa 'regularização' da EJA [institucionalização crescente nas redes municipais] aponta para a forte tensão entre uma concepção mais flexível de currículo, que a aproxima da tradição da educação popular e a tradição escolar dos sistemas regulares de ensino" (HADDAD, 2007, p. 208).

As ações do município de São Paulo para EJA também podem ilustrar essa tensão, elas compreendem diversas alternativas voltadas à modalidade na rede municipal de ensino. Desde 2003, a EJA é realizada nas Escolas Municipais de Ensino Fundamental (EMEFs) e Escolas Municipais de Ensino Fundamental e Médio (EMEFMs), no Movimento de Alfabetização (MOVA), no Centro Municipal de Capacitação e Treinamento (CMCT), nos Centros Integrados de Educação de Jovens e Adultos (CIEJAs) e na EJA Modular (a partir de 2011). A diversidade das propostas pouco tem refletido no número de matrículas da educação de jovens e adultos na cidade.

Entre os anos de 2004 e 2012 observamos a queda acentuada no número de matrículas na modalidade EJA do Ensino Fundamental em todas as esferas administrativas. Na rede municipal de ensino, houve um decréscimo de $59,5 \%$ no período.

A descontinuidade das propostas entre governos também é marcante na oferta e atendimento educacional aos jovens, adultos e idosos.

Tabela 2- Evolução das Matrículas ${ }^{4}$ no Ensino Fundamental de Jovens e Adultos por Dependência Administrativa no Município de São Paulo (2000/2012)

\begin{tabular}{lcccc}
\hline \multicolumn{1}{c}{ Ano } & $\mathbf{2 0 0 0}$ & $\mathbf{2 0 0 4}$ & $\mathbf{2 0 0 8}$ & $\mathbf{2 0 1 2}$ \\
\hline Total & 248.988 & 281.063 & 259.386 & 139.753 \\
\hline Estadual & 75.706 & 115.844 & 139.107 & 75.257 \\
Municipal & 133.580 & 149.662 & 113.676 & 60.586 \\
Privada & 39.702 & 15.557 & 6.603 & 3.910 \\
\hline
\end{tabular}

Fonte: Censo Escolar MEC/Inep e Centro de Informações Educacionais da Secretaria de Estado da Educação. Tabela Adaptada de Infocid@ade/SMDU/Dipro/PMSP.

A tabela 2 revela que na administração municipal houve um aumento de 12,03\% nas matrículas entre 2000 e 2004, período que coincide com a gestão de Marta Suplicy (2001-

\footnotetext{
${ }^{4} \mathrm{O}$ número de matrículas, baseado nas fontes citadas nessa tabela, divergem dos números apresentados pelo Relatório Anual de Fiscalização do Tribunal de Contas do Município em 2009, o qual aponta menos matrículas entre 2006 e 2009, baseado no Relatório de Dados Gerenciais SME-ATP/CI.
} 
2004), em que se rearticulava o Movimento de Alfabetização (MOVA). Também nesses anos foram implantados os Centros Integrados de Educação de Jovens e Adultos (CIEJAs) em substituição aos Centros Municipais de Ensino Supletivo (CEMES), pretendendo aliar a escolarização à qualificação profissional e atender às especificidades dos estudantes.

Caracterizados como proposta "inovadora" entre as demais ofertas para EJA na cidade, os CIEJAs são uma das alternativas que atravessaram diferentes governos.

Os Centros também apresentam queda no número de matrículas desde que foram implantados em 2003 até 2012. No entanto, o decréscimo de 8,6 \% é significativamente inferior à redução de matrículas nas EMEFs, que chega a alarmantes 62,9\% no mesmo período (CI/SME, 2012), conforme a tabela 3:

Tabela 3 - Evolução do número de matrículas em CIEJAs e EMEFs (2003/2012) MATRÍCULAS NOS CIEJAS E EMEFS

\begin{tabular}{ccccccc}
\hline \multicolumn{3}{c}{ MATRíCULAS NOS CIEJAs } & \multicolumn{3}{c}{ MATRíCULAS NAS EMEFs } \\
Ano & EJA Anos Iniciais* & Anos Finais* & Total & EJA Anos Iniciais* & EJA Anos Iniciais* & Total \\
\hline 2003 & 5520 & 6822 & $\mathbf{1 2 3 4 2 * * *}$ & 27892 & 103760 & $\mathbf{1 3 1 6 5 2}$ \\
2004 & 3561 & 8697 & $\mathbf{1 2 2 5 8}$ & 28306 & 108125 & $\mathbf{1 3 6 4 3 1}$ \\
2005 & 4381 & 9468 & $\mathbf{1 3 8 4 9}$ & 27377 & 104545 & $\mathbf{1 3 1 9 2 2}$ \\
2006 & 4206 & 8958 & $\mathbf{1 3 1 6 4}$ & 22622 & 87849 & $\mathbf{1 1 0 4 7 1}$ \\
2007 & 3869 & 7982 & $\mathbf{1 1 8 5 1}$ & 17996 & 70763 & $\mathbf{8 8 7 5 9}$ \\
2008 & 4306 & 9453 & $\mathbf{1 3 7 5 9}$ & 18273 & 80562 & $\mathbf{9 8 8 3 5}$ \\
2009 & 3813 & 8721 & $\mathbf{1 2 5 3 4}$ & 15590 & 60236 & $\mathbf{7 5 8 2 6}$ \\
2010 & 3612 & 8061 & $\mathbf{1 1 6 7 3}$ & 13121 & 54093 & $\mathbf{6 7 2 1 4}$ \\
2011 & 3576 & 7793 & $\mathbf{1 1 3 6 9}$ & 10907 & 45845 & $\mathbf{5 6 7 5 2}$ \\
2012 & 3195 & 8074 & $\mathbf{1 1 2 6 9}$ & 9367 & 39454 & $\mathbf{4 8 8 2 1}$ \\
\hline
\end{tabular}

Fonte: SME - Centro de Informática. Anos 2004 a 2012 - Censos MEC

* Os anos iniciais correspondem ao, então designados, Ciclo I do Ensino Fundamental, de $1^{\mathrm{a}}$ a $4^{\mathrm{a}}$ série e os anos finais ao Ciclo II, de $5^{\mathrm{a}} \mathrm{a} 8^{\mathrm{a}}$ série.

** O total de matrículas em 2003 não contabiliza 2.927 matrículas nos anos iniciais em modalidade semipresencial, durante a transição entre CEMES-CIEJAs.

Os números indicam a tendência de concentração da EJA em determinados pólos - os CIEJAs, porém sua capacidade de vagas não é suficiente para receber os jovens, adultos e idosos que ainda não concluíram o Ensino Fundamental e continuam fora da escola. São, portanto, necessárias as investigações que tangenciam as causas da intensa redução de matrículas nas EMEFs, bem como sobre os fatores que conduzem a menores quedas de

\footnotetext{
${ }^{5}$ Termo que caracteriza os CIEJAs nos pareceres do Conselho Municipal de Educação (CME) 81/06, aprovado em 24/08/06 e n ${ }^{\circ}$ 105/07, aprovado em 13/12/07. O mesmo se repete no documento de Reestruturação da EJA no Município (2008).
} 
matrícula nos CIEJAs.

Conforme Di Pierro e Ximenes (2011) existem dois eixos de investigação sobre os motivos da queda das matrículas em no Estado de São Paulo e municípios paulistas: o primeiro focaliza as políticas públicas e o segundo busca compreender as motivações dos estudantes e os desafios para prosseguir os estudos. Neste último caso, os autores destacam:

(...) para explicar a redução das matrículas na educação escolar desse grupo, é
necessário considerar também os fatores internos ao sistema educativo, como a
disponibilidade, a acessibilidade, a organização, a qualidade e a relevância da
educação escolar que tem sido oferecida para os jovens e adultos que são seus
potenciais destinatários. (DI PIERRO; XIMENES, 2011, p. 7)

São poucos os estudos que abordam o CIEJA entre as políticas municipais de São Paulo, e aqueles existentes tratam mais especificamente do currículo, das trajetórias dos educandos ou das práticas escolares de um dos 14 Centros da cidade, sem propriamente focarse no campo político (ALVES, 2012; BRITO, 2009; FELIPE, 2010; RODRIGUES, 2008; VIANA, 2011).

Em relação às políticas para EJA na cidade de São Paulo, Camargo (1996) e Abonnízio (2007) concentraram-se na análise da parceria entre a SME e o MOVA, marcadamente durante os governos de Luíza Erundina e Marta Suplicy. Moreira (2009) pesquisou o ProJovem na região metropolitana de São Paulo e Spósito et. al. (2005) trataram das políticas de EJA na mesma região, apontando descontinuidades entre elas que dificultam a articulação entre os níveis de ensino. Possani (2008) estudou a construção de currículos emancipatórios para EJA na perspectiva das políticas públicas, concentrando-se na análise do Movimento de Reorganização Curricular da EJA na cidade de São Paulo, durante o governo de Marta Suplicy (2001-2004); a autora concluiu que é necessário articular a utopia, a ética e ação pedagógica, além de "conciliar o tempo da política, dos governos e da ação pedagógica" (POSSANI, 2008, p.7).

Nesse cenário, são necessárias as pesquisas sobre como o município de São Paulo tem desenhado as propostas de ensino para EJA. Transitamos nesse campo, considerando que as políticas públicas viabilizam a constituição de espaços educativos mais adequados às condições dos estudantes da EJA, ao mesmo tempo, são os sujeitos que dão corpo às políticas.

É a própria legislação que está propondo às autoridades e aos educadores a tarefa de investigar e definir modalidades de realização do trabalho educativo adequadas às condições de vida de jovens e adultos trabalhadores. Neste sentido, talvez a questão da competência técnica na educação de jovens e adultos esteja sendo discutida em trabalhos recentes de maneira incompleta. Além do necessário domínio das técnicas 
de trabalho pedagógico e do conhecimento das características especiais de jovens e adultos, impõe-se examinar principalmente a questão dos modelos de organização das atividades educativas, de modo a adequá-las às peculiaridades e às possibilidades de sua clientela. E é sempre importante não esquecer que a principal peculiaridade dos jovens e adultos analfabetos é a sua condição de portadores de uma situação de classe. (BEISIEGEL, 1997, p. 33)

Nosso trabalho procurou, então, compreender como o modelo de organização escolar dos CIEJAs foi construído entre os diferentes governos da cidade. Partimos das seguintes questões:

1) Como as políticas públicas para EJA constituíram os CIEJAs?

2) Qual a participação da equipe técnica dos Centros (professores e gestores) na constituição do modelo escolar dos CIEJAs?

A hipótese inicial foi de que a participação de gestores e professores dos Centros nas discussões de idealização, adaptação, avaliação e regulamentação ao longo dos anos teria influenciado a constituição de seu projeto, favorecido sua continuidade entre os diferentes governos do município e conferido maior adequação às peculiaridades dos estudantes.

Registramos a história do Projeto CIEJA, compreendendo-a enquanto processo, que abarca continuidades e rupturas entre sua idealização em 2001 e a elaboração do Novo Projeto CIEJA em 2009. Analisamos esse período considerando que a trajetória das escolas é marcada, de um lado, pela ação dos sujeitos e especificidades locais e, de outro, enreda-se no contexto político, histórico e social mais amplo. A pesquisa não alcança, porém, o período mais recente de institucionalização do Projeto CIEJA, com a regulamentação da Lei 15.648/12, que estabelece diretrizes para o funcionamento dos Centros.

Nossa pesquisa é apresentada em quatro capítulos. Além deste introdutório, que apresenta seu contexto, objetivo e hipótese, abordamos também as etapas de pesquisa e os referenciais teórico-metodológicos com que trabalhamos, a fim de melhor informar o leitor sobre os pressupostos que nos orientaram.

No capítulo 2, apresentamos as políticas públicas de EJA na cidade de São Paulo, analisando sua influência na constituição do Projeto CIEJA ao longo dos anos.

No capítulo 3, detivemo-nos na análise do modelo dos Centros e o perfil dos educandos. Finalmente, no capítulo 4, encerramos nossa dissertação com a apresentação das considerações finais. Antes, porém, convém descrever os CIEJAs. 


\subsection{Os Centros Integrados de Educação de Jovens e Adultos}

A cidade de São Paulo possui 14 unidades de CIEJAs com cursos presenciais de Ensino Fundamental, organizados em quatro módulos com duração de um ano cada.

São eles: CIEJA Aluna Jéssica Nunes Herculano (Butantã); CIEJA Campo Limpo; CIEJA Ermelino Matarazzo; CIEJA Itaquera; CIEJA Parelheiros; CIEJA Santo Amaro; CIEJA Santana/Tucuruvi; CIEJA Vila Prudente/Sapopemba; CIEJA São Mateus; CIEJA Cambuci; CIEJA Vila Maria/Vila Guilherme; CIEJA Vila Clóvis Caetano Miquelazzo - Ipiranga; CIEJA Prof $^{a}$ Rosa Kazue Inakake de Souza; CIEJA Prof ${ }^{a}$. Rose Mary Frasson.

Desde a implantação dos CIEJAs até o ano de 2012, apenas um novo centro (em Parelheiros) foi implantado em 2004 através do Decreto nº4787 de 18/06/2004.

Os Centros estão distribuídos em 11 das 14 Diretorias Regionais da Educação, unidades administrativas da SME, conforme o Mapa 2.

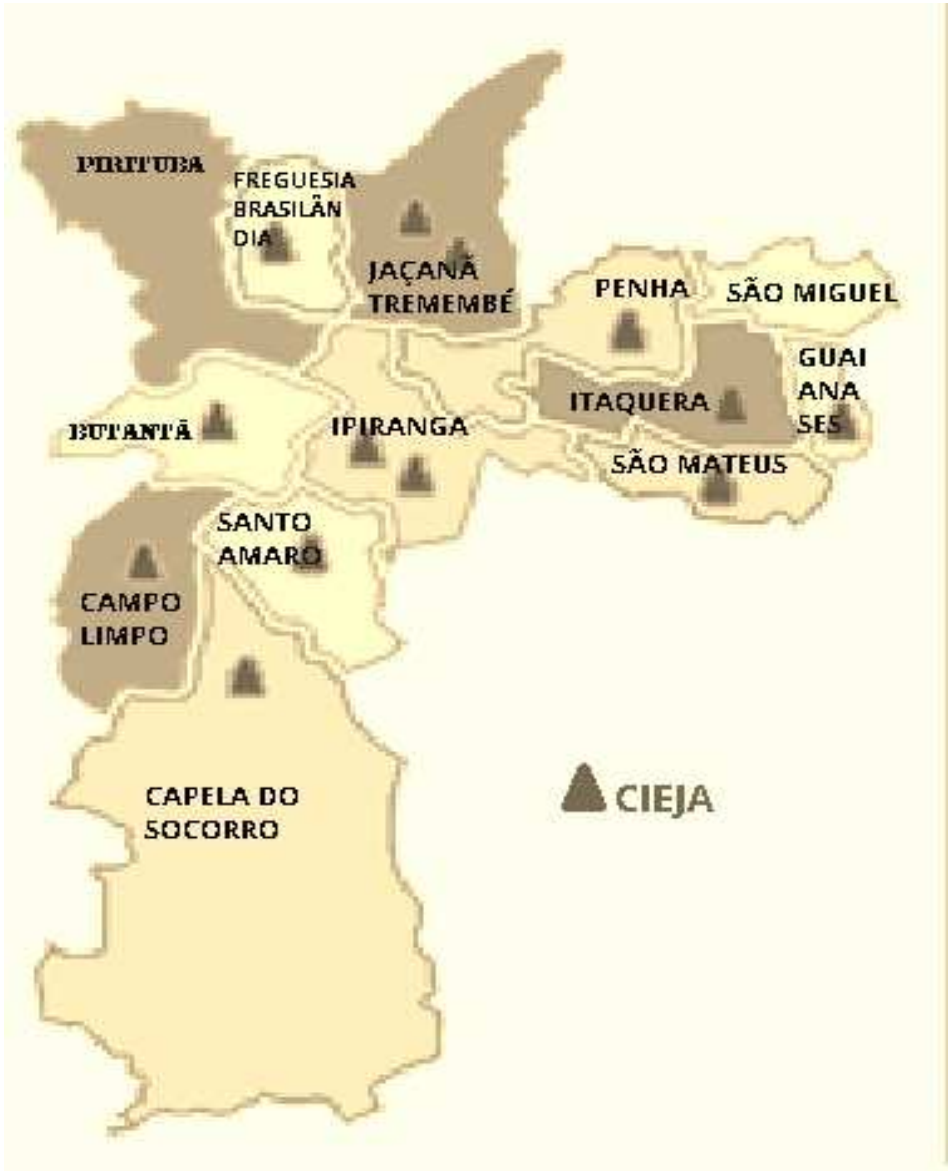

Mapa 2- Distribuição dos CIEJAs na cidade de São Paulo 
Idealizados em 2001 após avaliação dos antigos Centros de Estudos Supletivos (CEMES) e implantados em 2003 como projeto experimental, os CIEJAs tinham em vista as seguintes diretrizes da Secretaria Municipal de Ensino (SME) na administração de Marta Suplicy: democratização do acesso e permanência; qualidade social da educação e democratização da gestão, conforme o Decreto Municipal nº 43.052, de 4 de abril 2003.

Com relação às duas primeiras diretrizes, os CIEJAs buscariam superar algumas questões de gestão e prática pedagógicas também apontadas por Arroyo (2008) como campos de grande relevância para a construção da escola democrática: a flexibilização dos horários de estudo e dos currículos para o pleno desenvolvimento dos estudantes; a reordenação dos tempos e espaços escolares; a reformulação da seriação em módulos de aprendizagem e a reorganização do trabalho coletivo dos docentes.

O planejamento e a organização do trabalho educacional voltado aos jovens e adultos
pressupõe o conhecimento dos alunos e de suas necessidades, além de flexibilidade
na organização curricular para o atendimento às demandas. A contextualização e
criação de mecanismos para a obtenção, sistematização e socialização do
conhecimento será o desafio constante dos educadores dos CIEJAs em seus espaços
coletivos de discussão. (DOT-EJA/SME-SP, 2004, p. 12)

Desde que foram implantados, os CIEJAs possuem atendimento exclusivo para jovens, adultos e idosos em turnos de duas horas e quinze minutos nos períodos: matutino, vespertino e noturno. Os cursos de Ensino Fundamental são organizados em quatro módulos anuais. Além de frequentarem sua turma em período específico, os alunos podem participar de atividades em turmas e horários diversificados para repor aulas, integrar projetos e receber orientações de estudo, buscando possibilitar que conciliem suas obrigações pessoais com a vida estudantil.

Segundo a proposta de desenvolver um currículo interdisciplinar, na perspectiva de superar a hierarquia entre disciplinas e a fragmentação dos saberes, configuram-se três áreas do conhecimento: Linguagens e Códigos (Português, Inglês, Artes e Educação Física), Ciências Humanas (História e Geografia) e Ciências da Natureza e Matemática.

Os Centros também oferecem os Itinerários Formativos, que visam integrar o Ensino Fundamental à formação profissional, que tiveram diferentes configurações ao longo dos anos, tendo permanecido em todos eles o de Informática.

Observa-se, ainda, que o Projeto CIEJA busca ampliar a concepção sobre os lugares e tempos de aprendizagem tradicionais nas escolas, ao incorporar ao currículo atividades culturais em espaços diversificados da cidade, como museus, parques, teatros, centros 
comunitários etc.

Com relação à diretriz de democratização da gestão, preconiza-se a participação da sociedade na condução dos Centros: o "incentivo e o reforço à participação das diferentes instâncias, internas e externas às unidades, é condição fundamental para maior qualificação na tomada de decisões" (DOT-EJA/SME-SP, 2004, p. 12).

As equipes dos CIEJAs são constituídas de Coordenador Geral, Assistente de Coordenação Geral, Orientadores Pedagógicos Educacionais, Professores e Funcionários da rede municipal concursados, que são selecionados e designados para os cargos. A seleção e designação especial, vigentes desde 2001, visavam atrair e reter nos CIEJAs profissionais preparados e identificados com sua proposta pedagógica, podendo garantir maior fixação ao seu quadro de servidores, propiciando o fortalecimento da construção coletiva das ações em cada unidade.

O Projeto aponta que a equipe docente é também a responsável pela contextualização e criação de mecanismos para a obtenção, sistematização e socialização do conhecimento em seus espaços coletivos de discussão. (PARECER CME $n^{\circ}$ 10/2002). De fato, é assim justificado que a participação o Horário Coletivo ${ }^{6}$ seja obrigatória para todos os docentes que ingressam nos Centros, visando à organização das rotinas escolares, o diálogo com as demandas estudantis, o planejamento e avaliação das práticas de maneira mais aproximada às necessidades e expectativas dos jovens, adultos e idosos.

Admitidos em caráter experimental, os Centros eram avaliados anualmente pelo Conselho Municipal de Educação (CME), que autorizavam a sua continuidade e geravam recomendações ao seu funcionamento, até a regulamentação da Lei 15.648/12, que estabelece diretrizes para o funcionamento dos CIEJAs.

Em 2006 alunos, professores e gestores - mobilizados pela unidade do Campo Limpo manifestaram-se contra a ameaça de encerramento dos CIEJAs, saindo às ruas com estudantes e educadores de outros Centros. Eles se dirigiram ao então Secretário da Educação Alexandre Schneider. "Ele foi convidado a visitar o CIEJA Campo Limpo - e aceitou. Em sua ida à escola lançou um desafio: dona $\hat{E} d a$ escrever o projeto para as 13 unidades de CIEJAs da

\footnotetext{
${ }^{6}$ Os docentes, geralmente, submetem-se à Jornada Especial Integral de Formação (JEIF) corresponde a 40 (quarenta) horas/aula semanais, sendo 25 (vinte e cinco) horas/aula de regência; 11 (onze) a serem cumpridas obrigatoriamente na escola e 04 (quatro) em local de livre escolha. Aqueles que não aderem a essa jornada de 40horas/aula, complementam os horários de reunião como horas extras.
} 
cidade" (LUIZ, 2013, p.31-32). A educadora Êda Luiz, Coordenadora Geral, buscaria visitar cada centro para cumprir a proposta. O projeto CIEJA foi escrito coletivamente e aprovado pelo CME em 2009. Ele basearia a lei 15.648, de 14 de novembro de 2012, que estabelece as diretrizes para seu funcionamento. Esse fato ocorreu após o início de nossa pesquisa extrapolando seu escopo, mas é inegável a importância dessa lei, pela qual as equipes dos CIEJAs se mobilizaram, e que concretiza a trajetória de lutas pela garantia de funcionamento dessas unidades educacionais.

Os CIEJAs, bastante diversos entre si, foram constituídos a partir de um Projeto comum, que sofreria diversas alterações, sejam aquelas formalizadas em portarias da SME; sejam aquelas formuladas pelos coletivos docentes. O objetivo de nosso estudo foi justamente elucidar como as equipes dos Centros construíram esse projeto comum, incidindo sobre a formulação da política pública de EJA no período 2001-2009.

\subsection{Etapas da pesquisa e referencial teórico-metodológico}

Este estudo compreendeu um duplo desafio: sistematizar a trajetória do Projeto CIEJA, atravessando distintas gestões (2001 a 2009) e analisá-la como parte das políticas públicas empreendidas para a modalidade na cidade de São Paulo.

O registro da trajetória do CIEJA procurou compreendê-la não apenas como justaposição de períodos lineares, mas como história em movimento, iniciativas que sofrem continuidades e rupturas devido à ação e interação de diferentes sujeitos. Desse modo, buscamos relacionar os documentos oficiais à memória da equipe técnica de EJA em SME e nos Centros (gestores e educadores).

Para investigar os cenários e as ações que enredaram as políticas municipais para EJA nas últimas décadas e a formação dos CIEJAs, dividimos nosso estudo em quatro etapas.

$\mathrm{Na}$ primeira, realizamos a revisão de literatura, recorrendo aos estudos acadêmicos sobre o tema. Na segunda etapa de nosso trabalho, procedemos à pesquisa documental, visando recuperar e organizar o acervo de documentos oficiais que registraram o início da elaboração dos CIEJAs e que regulamentaram seu funcionamento ao longo dos anos. Dentre os documentos levantados, escolhemos aqueles considerados pertinentes para construção do 
Projeto CIEJA: os que revelam a definição dos problemas que levaram à sua criação ou as soluções que ele incorpora, os que o implantavam na rede municipal; os que revelam alguma forma de participação dos sujeitos que trabalhavam nos Centros em sua elaboração e os que provocavam ou avaliavam mudanças significativas em sua organização.

$\mathrm{Na}$ terceira etapa da pesquisa realizamos um mapeamento dos atores dos Grupos de Trabalho (GTs) que participaram da idealização e implementação dos CIEJAs ou da elaboração do Novo Projeto CIEJA. Contamos com a colaboração da Coordenadora Geral do CIEJA Butantã, Daniele Brasil, que elucidou a constituição dos GTs, contribuindo para elaborarmos as perguntas-chave das entrevistas semiestruturadas.

Os GTs eram compostos por profissionais da Equipe de Diretoria de Orientações Técnicas da EJA (DOT-EJA), da Equipe Pedagógica dos Núcleos de Ação Educativa (NAEs) ${ }^{7}$ Coordenadores e Educadores em exercício nos Centros.

Dentre esses diversos atores, foram selecionadas para entrevista as dirigentes da DOTEJA no período relativo à composição de cada GT, uma Professora, uma Orientadora Pedagógico Educacional (correspondente à Coordenadora Pedagógica nas unidades escolares) e uma Coordenadora Geral de unidade (correspondente à Diretora da unidade). Essa seleção responde à intenção de capturar a percepção dos sujeitos em diferentes instâncias hierárquicas sobre a constituição do Projeto CIEJA.

As profissionais dos CIEJAs entrevistadas permaneceram em exercício no Butantã e Campo Limpo desde sua idealização em 2001 até a realização desta pesquisa, motivo pelo qual foram selecionadas, contribuindo com uma visão longitudinal sobre a implantação dos Centros.

Entrevistamos, também a Sra. Marisa Teresa Nori, representante do SENAC, que respondeu pelos Itinerários Formativos entre 2001 e 2003. Lívia Maria Antogiovani, diretora de DOT EJA em 2012, também contribuiu com a pesquisa, contextualizando os centros na atualidade.

$\mathrm{Na}$ quarta e última etapa, entramos propriamente na análise da política pública. Utilizamos como instrumento de análise o Modelo de Múltiplos Fluxos (Multiple Streams)

\footnotetext{
${ }^{7}$ Os órgãos regionais da SME foram chamados de Núcleos de Ação Educativa entre 1989 e 1992. De 1993 a 2000, as NAES passaram a ser designadas Diretorias Regionais de Ensino Municipal (DREM). De 2001 a 2002 , os órgãos regionais voltaram a ser denominados NAEs. Em 2003, as 13 NAEs foram expandidas para 31 Coordenadorias de Educação (CE) acompanhando o número de subprefeituras. No entanto, em 2005 voltaram a existir 13 CEs, que em 2008 foram designadas de Diretorias Regionais de Educação (DREs) (POSSANI, 2008).
} 
desenvolvido por John Kingdon (2003), que abordaremos mais adiante. Pretendemos compreender como foram concebidos os problemas e desenhadas as soluções que configuraram os CIEJAs. Por fim, procedemos à síntese das análises.

Apresentamos a seguir algumas considerações sobre as concepções de EJA presentes nos documentos e políticas da cidade; sobre a gestão democrática do ensino público; o tratamento das entrevistas realizadas e a nosso método de análise sobre a formação de políticas públicas.

\title{
1.3.1 Considerações sobre as concepções de EJA
}

\begin{abstract}
Não há nem jamais houve prática educativa em espaço-tempo nenhum de tal maneira neutra, comprometida apenas com idéias preponderantemente abstratas e intocáveis. Insistir nisso e convencer ou tentar convencer os incautos de que essa é a verdade é uma prática política indiscutível com que se pretende amaciar a possível rebeldia dos injustiçados. Tão política quanto a outra, a que não esconde, pelo contrário, proclama, sua politicidade. (FREIRE, 1992, p. 35)
\end{abstract}

Como bem explicitam as palavras de Paulo Freire (1992), não existe neutralidade na ação educativa. A aparente neutralidade com que se apresentam é tanto uma opção política pela manutenção da ordem estabelecida quanto o é a prática que se pretende emancipadora e se declara politizada.

As propostas pedagógicas podem operar segundo um tipo ideal de homem e sociedade que as posiciona politicamente enquanto instrumento de legitimação e reprodução das relações sociais existentes ou enquanto reveladora das formas de dominação das camadas populares, mirando sua transformação. De acordo com a intencionalidade e o projeto de sociedade com que é engendrada a EJA, podemos encontrar propostas de ensino mergulhadas na vivência e expectativas dos jovens, adultos e idosos, ou alheias a elas, conferindo ao povo um determinado papel na história e no desenvolvimento do país. Dificilmente uma proposta educativa é, de fato, só uma ou outra coisa; existem largos terrenos entre aquilo que se propõe, aquilo que se faz e os efeitos que se obtém. Contudo, as concepções de educação marcam, em diferentes graus, as práticas e seus resultados; apoiando-se em determinado olhar sobre os sujeitos e a sociedade. 
O preconceito em relação aos sujeitos da EJA parece permanecer no imaginário social, alimentando reducionismos na definição de prioridades educacionais do país (DI PIERRO; GALVÃO, 2007) Ele se baseia em crenças, ideias e valores que merecem algumas reflexões: Há uma idade certa para aprender? Como aprendemos, em que espaços, em que tempos? Por que e o que devemos aprender? Quais são os aprendizados que valorizamos?A depender das respostas encontradas para essas questões, observamos variadas políticas públicas, concebidas segundo a concepção compensatória, o paradigma da Educação Popular ou o conceito de educação ao longo da vida (DI PIERRO; JOIA; RIBEIRO, 2001).

Estão em jogo não só os significados atribuídos aos conceitos de cidadania, alfabetização, inclusão, participação, mas aos projetos de sociedade a que servem.

Ora, os nomes são muitos e debaixo deles: educação popular, educação de base,
educação de adultos, educação fundamental, educação comunitária, educação
permanente, há coisas e intenções iguais, semelhantes e até opostas. Neste
emaranhado estão escondidas ideias iguais com rótulos diferentes e ideias diferentes
com rótulos iguais. Há projetos e, sobretudo, há propósitos, muitas vezes opostos,
que se cobrem das mesmas falas e, com palavras que pela superfície parecem apontar
para um mesmo horizonte, procuram envolver as mesmas pessoas, prometendo a elas
mudanças nas suas vidas, ou em seus mundos. (BRANDÃO, 1984, p. 15)

As diferentes propostas educativas para jovens e adultos podem ratificar o olhar discriminatório sobre os sujeitos, partindo das trajetórias escolares interrompidas, daquilo que lhes faltaria - a escolarização tal qual concebida para as crianças - ou sob o estigma do analfabeto, daquele que é descrito como um "cego" em sociedade (DI PIERRO; GALVÃO, 2007). Podem partir também de um projeto social em que esses sujeitos já possuiriam um lugar pré-determinado no futuro, respondendo à demanda de formação de consumidores e de mão de obra qualificada, antes como fator do crescimento econômico do país, do que como sujeitos de direitos.

Nesse sentido, desencadeiam-se ações, muitas vezes, assistencialistas, que atuam como "remédio" destinado àqueles que voltam aos bancos escolares como se estivessem apenas em busca de uma chance perdida.

Baseadas numa visão compensatória da EJA, as ações educativas prometem neutralizar uma pretensa falta de formação em cursos que mimetizam o currículo do ensino para as crianças de maneira acelerada, marcando a história da EJA no país.

Da queda do Estado Novo à década de 1960, as iniciativas educativas voltadas aos jovens, adultos e idosos, inspiradas nos ideais do liberalismo europeu e nos interesses 
capitalistas para manutenção de certa hierarquia social, desenvolveram-se segundo a intencionalidade de grupos dominantes, empenhados em definir um tipo ideal de homem adequado ao desenvolvimento econômico.

(...) a ideologia do desenvolvimento não é doação feita às classes populares, para que cada um absorva na medida de sua capacidade; pelo contrário, é transmutação que se opera na intimidade do homem em situação, e de que resulta a clarificação conceitual da representação que faz do seu status social e da evolução histórica. É processo imanente, mas admite aceleração por influência exterior. Isto é que constitui a noção social de educação (...). Uma teoria da educação deverá surgir cuja tarefa será a de definir o tipo de homem que se deseja formar para promover o desenvolvimento do país. Em função desse objetivo deverão ser revistos os atuais esquemas educacionais, a fim de que, sem abandonar o que seja aconselhável manter da tradição, se concentrem os esforços pedagógicos na criação de nova mentalidade. As gerações em crescimento deverão ser preparadas para a compreensão do seu papel histórico, na transição da fase porque está passando a sociedade brasileira, capacitando-se das suas responsabilidades no processo. (PINTO, 1959 apud BEISIEGEL, 1982, p. 55) Grifo nosso.

A ideologia do desenvolvimento não se impôs apenas pela situação vivenciada pelos jovens e adultos durante a intensificação da urbanização e a industrialização do país quando buscavam a escolarização para conseguir empregos, acessar a cultura letrada das cidades e ascender socialmente - mas se amparava na ação educativa para acelerar e ordenar a "transmutação" ou conscientização dos indivíduos.

Ao mesmo tempo em a escolarização dos trabalhadores era necessária para suprir os novos postos de trabalho nas indústrias, escolarizá-los possibilitaria criar entre eles hábitos necessários para criação de um mercado interno de consumidores daquele novo estilo de vida em sociedade.

Nesse contexto, a EJA também espelharia a educação compensatória, que exigia dos trabalhadores o dever de recuperar aprendizados necessários para o cumprimento de seu "papel histórico", mais do que a possibilidade de conquistarem o direito que tiveram negado na infância.

Essa modalidade de ensino vem sendo, então, sistematicamente submetida a regulamentações institucionais retrógradas, que recuperam esse sentido de educação para ratificar uma velha "nova mentalidade", segundo a qual a escolaridade passa a significar degrau para a ascensão social; as práticas se realizam segundo a reprodução do ensino regular de forma acelerada e reduzida; a história se constitui como traço verticalizado em direção à evolução e os indivíduos já possuem "responsabilidades” delimitadas. A educação, 
quando realizada segundo essa intencionalidade, pode cumprir a função de controle social em que, pensada pela elite para instrução do povo $^{8}$, oculta certo ideal de organização social em que, muitas vezes, ela pretende manter sua posição privilegiada de elite e dar continuidade às relações de desigualdade existentes.

$\mathrm{Na}$ mesma época em que se proclamavam os discursos que atrelavam a EJA às necessidades do mercado capitalista, observamos pensamentos divergentes em diferentes grupos organizados da sociedade civil, configurando o paradigma da Educação Popular. Desde a década de 1960, observamos que esses grupos passavam a desenvolver práticas pedagógicas aproximadas do pensamento e prática do Professor Paulo Freire, em que a educação ocupa um lugar de libertação e transformação. Empenhado em conceber a educação que não fosse mera estratégia de reprodução das relações sociais, ou apenas conduzisse os indivíduos como objetos, Freire apostava nos educandos não apenas como receptores ou "instrumentos" de um projeto de futuro, nem somente como "produtos" dele, mas sim como sujeitos reflexivos, atuantes nele. A educação dos jovens e adultos, então, deveria posicionar-se politicamente para revelar as formas de exploração e dominação dos sujeitos, fomentando sua atuação na sociedade. Os caminhos percorridos na Educação Popular apontavam não para o futuro enquanto dado pré-concebido, mas para uma realidade em suspenso, a ser construída com os educandos.

Desse modo, o notável educador desenvolveu reflexões importantes para a participação ativa dos homens em seu tempo quando se referia à cultura e ao diálogo enquanto pressupostos da formação da personalidade democrática.

(...) a partir destas relações do homem com a realidade e nela, criando, recriando, decidindo, que ele vai dinamizando o seu mundo. Vai dominando a realidade externa. Vai acrescentando a ela algo de que é mesmo o fazedor. Vai temporalizando os espaços geográficos. Faz cultura. E é ainda o jogo dialético de suas relações- com que marca o mundo refazendo-o e com o que é marcado que não permite a "estaticidade" das sociedades nem das culturas. (FREIRE, 1967, p.43)

A partir do diálogo, como método de alfabetização e conscientização popular, Freire refletia sobre a riqueza da comunicação, a centralidade da palavra na estruturação do pensamento e sua potencialidade formadora de ideias, e porque também (re)formadora de

\footnotetext{
${ }^{8}$ Beisiegel (1982) esclarece que a palavra "povo" foi utilizada nos discursos políticos dos anos 1950 sugerindo a homogeneização das políticas à população brasileira, ocultando as diferenças sociais e culturais. O autor esclarece que essa pretensa homogeneidade estaria presente também no início dos trabalhos de Paulo Freire (1967), posteriormente sendo criticada pelo próprio educador, que utilizaria os conceitos de oprimidos e opressores.
} 
ideias, potencialmente (re)construtora de realidades. Daí que a leitura da palavra sucedesse a leitura de mundo e que a leitura de mundo pudesse ser enriquecida pela leitura da palavra. Freire opunha-se, então, à educação reprodutora e verticalizada, à "educação bancária”. Ao conceder relevância à intersubjetividade implicada no diálogo, vislumbrara a possibilidade de que a educação partisse da intencionalidade de quem a promovia para ser também mergulhada na intencionalidade e vivência daqueles que dela participavam.

O pensamento do Professor Paulo Freire contribui fortemente para as iniciativas educativas desenvolvidas com jovens, adultos e idosos das camadas populares. A prática do diálogo e o reconhecimento dos sujeitos como produtores de cultura foram pontos centrais de diferentes propostas educacionais nos anos de 1960. Marcada a diversidade das intenções e projetos nessas propostas educacionais, verifica-se que elas buscavam a crítica à realidade experimentada pela população em vez de sua conformação. O golpe militar de 1964 impediu a continuidade de variadas experiências ${ }^{9}$, que legaram, porém, aprendizados que reverberam em diversas propostas e práticas da EJA no Brasil desde então. Tais propostas e práticas educativas implicariam o diálogo, a reflexão do homem sobre sua circunstância, seu posicionamento enquanto sujeito, a possibilidade de que os educandos participem ativamente da constituição da cultura e história.

Nessa direção, Arroyo (2005) aponta a necessidade de superar o olhar preconceituoso sobre os sujeitos e reconhecer seu protagonismo social e cultural como forma de configurar a especificidade da EJA.

A Conferência Internacional de Educação de Jovens e Adultos de Hamburgo em 1997 (CONFINTEA 1997) ratificaria a importância da EJA para o pleno exercício da cidadania, o respeito à diversidade cultural e desenvolvimento de comunidades sustentáveis. Incorporavase também o discurso da educação ao longo da vida, um conceito ainda bastante controverso, uma vez que assume sentidos distintos de acordo com os grupos que o utilizam para gerar ou justificar suas ações.

O termo "ao longo da vida", em princípio, trata da ampliação da visão sobre educação para diferentes espaços e tempos, compreendendo que qualquer indivíduo, independente de faixa etária, é cognitivamente e socialmente capaz de aprender, modificar hábitos e atitudes.

\footnotetext{
${ }^{9}$ São exemplos dessas experiências o Movimento e Educação de Base (MEB), os Centros Populares de Cultura da União Nacional dos Estudantes (UNE) e o Movimento de Cultura Popular (MCP) de Recife.
} 
Dessa maneira, a educação extrapolaria os limites da escolarização.

Parto do pressuposto que o ideal de educação ao longo da vida corresponde a um projecto político-cultural de grande amplitude, capaz de compreender modalidades de educação formal, não-formal e informal, a educação política, a formação cultural e para a cidadania democrática, tanto quanto a formação profissional e a formação contínua. (LIMA, 2007)

A concepção de educação ao longo da vida remeteria à discussão sobre a Educação Permanente de 1972, que "dava relevo à ideia de que o processo educativo é coincidente com o ciclo de vida dos indivíduos, sendo a construção da pessoa uma dimensão essencial desse processo numa visão que alguns designam de existencialista”. (ALVES, 2010, p.11). Posta no cenário da expansão da globalização, internacionalização da economia, difusão da informação e das mudanças na organização do trabalho e no mercado capitalista, a ideia de educação ao longo da vida também tem sido utilizada por outras vertentes. Segundo Alves (2010) os riscos que a difusão do termo provoca são: sua redução às ações nos sistemas formais de ensino; sua equiparação à educação de adultos; sua compreensão como ferramenta de capacitação ou profissionalização para fins econômicos, competitivos e acomodação ao mercado capitalista; ou sua utilização para fomentar políticas em que o indivíduo tende a ser o responsável pela própria formação.

Reconhecendo as desigualdades sociais, a instabilidade do futuro, determinadas iniciativas de ensino buscariam moldar o tipo de homem ideal para se adaptar às constantes transformações econômicas, sociais e culturais.

Existem críticas ao discurso que aproximam a educação ao longo da vida das necessidades mercadológicas do capital ou da adaptação dos homens e mulheres ao futuro instável, ao "mundo multirriscos" (DELORS, 1999, p.44). Elas têm ecoado em trabalhos de pesquisadores brasileiros (RUMMERT, 2010; VENTURA, 2013) e tratam, em geral, sobre as tendências dos riscos mencionados por Alves (2010) em reduzir o conceito mais amplo de educação ao longo da vida à formação de mão de obra qualificada. Essa redução coincide com o que Lima (2007) designa como "mão direita da educação ao longo da vida". O autor utiliza a metáfora da mão esquerda e direita de Miro para contrapor "uma direita mais funcional $e$ conservadora e uma esquerda mais criativa e transformadora" (LIMA, 2007, p.8). A educação ao longo da vida estaria localizada dialeticamente entre esses extremos, de acordo com os contextos políticos, econômicos e sociais específicos tenderia de um lado para a empregabilidade e performatividade competitiva, ajustando o indivíduo ao mercado de 
trabalho, de outro às práticas da educação popular, confrontando os desafios do emprego e trabalho sem fugir das responsabilidades éticas em promover a transformação de trajetórias individuais e coletivas (LIMA, 2007).

"Como se compreende, a crítica à 'mão direita' da educação ao longo da vida assenta
no seu carácter pragmatista e na tendência para a procura de soluçôs pedagogistas e
individuais para enfrentar problemas estruturais de manifesta magnitude e
complexidade" (LIMA, 2007, p. 87)

Explorar os diferentes propósitos e contextos em que se usa o termo "educação ao longo da vida" parece-nos mais profícuo para o debate de ideias do que acatar apenas um deles, ainda que para criticá-lo. Se os sentidos estão em disputa, tomar um único como verdadeiro seria o mesmo que desistir de uma batalha.

Consideramos em nosso trabalho que a perspectiva da educação ao longo da vida reanima uma visão ampliada sobre os processos educativos e seus sujeitos, recolocando a formação de jovens, adultos e idosos na agenda das políticas públicas, potencializando o respeito à diversidade e trajetórias individuais. No entanto, ela tem respaldado projetos de sociedade bastante diversos. Buscamos, então, proceder como Lima (2007):

Procuro, assim, compreender as mutações que vêm ocorrendo neste campo, as
ambiguidades e as contradições resultantes de distintas perspectivas políticas e
sociais que em torno do conceito polissêmico de educação ao longo da vida têm sido
construídas, chamando a atenção para o seu potencial democrático, mas também para
as derivas economicistas e tecnocráticas já amplamente subordinadas à
empregabilidade e à performatividade competitiva. (LIMA, 2007, p.86)

Da mesma maneira, avaliamos como as diferentes concepções de EJA permearam as decisões dos sujeitos na trajetória do CIEJA e as políticas para essa modalidade de ensino na cidade de São Paulo.

\subsubsection{Considerações sobre a gestão democrática do ensino público}

A democratização da sociedade brasileira implicou a extensão do ensino público às camadas populares, como meio de prover à população condições de se integrar ao mercado de trabalho, participar das decisões públicas e exercer a cidadania.

Ao lado da expansão das vagas nas escolas, constatava-se, desde o século XX, a inadequação de seu modelo tradicional à população que passava a ocupar o território antes 
reservado à formação das elites dirigentes do país. Daí a necessidade de que a escola fosse não apenas acessível a todos, mas desenvolvesse processos educativos inclusivos.

A redemocratização do país, a partir de 1985, teve importante atuação de diferentes grupos da sociedade civil organizada que clamavam pela equalização dos direitos e reanimavam a discussão sobre a universalização da escola básica e instituição de meios de participação popular na gestão das instituições públicas.

(...) o confronto e o antagonismo que tinham marcado profundamente a relação entre o Estado e a sociedade civil nas décadas anteriores cederam lugar a uma aposta na possibilidade da sua ação conjunta para o aprofundamento democrático. Essa aposta deve ser entendida num contexto no qual o princípio de participação da sociedade se tornou central como característica distintiva desse projeto, subjacente ao próprio esforço de criação de espaços públicos, onde o poder do Estado pudesse ser compartilhado com a sociedade (DAGNINO, 2004, p.142).

A descentralização do ensino poderia, então, favorecer "a democratização e a qualidade da educação porque potencializa a participação social nas instâncias locais de poder" (DI PIERRO, 2005, p. 1126). Não é por acaso que, ao lado dos princípios de igualdade de condições de acesso e permanência na escola na Constituição Federal de 1988, constem o princípio da gestão democrática.Tratava-se da possibilidade de que o poder pudesse ser partilhado entre os membros das comunidades escolares em vez de se concentrar nas mãos dos dirigentes políticos ou técnicos educacionais, de maneira que as práticas também remetessem a uma qualidade social da educação.

Segundo Arroyo, seria necessário pesquisar em que medida as escolas e sistemas de ensino "pautaram sua gestão 'participativa' pelo reconhecimento dos educandos, das famílias e dos educadores como sujeitos de direitos (...) ou ainda prevalece sua visão reduzida a empregáveis, a mercadoria competente para as demandas do mercado segmentado?" (ARROYO, 2008, p. 42)

O autor também aponta que a gestão democrática do ensino público tem sido tratada como se correspondesse apenas à gestão democrática das unidades escolares. Tal qual figurava entre os debates pela democratização da sociedade, ela não se restringiria à administração escolar ou à possibilidade de construção de um projeto pedagógico próprio, mas extrapolava os muros da escola, visando à construção de outro projeto de "Estado e sociedade, com a participação consciente dos cidadãos" (ARROYO, 2008, p.42).

Tem-se discutido os meios de participação dos usuários, familiares e trabalhadores na tomada de decisão nas escolas (através dos conselhos escolares, associações de pais e mestres, 
grêmios, conselho de classe), os meios de impulsionar o envolvimento de seus membros ou a escolha democrática dos seus dirigentes. "Todas essas medidas democratizantes, todavia, não conseguiram modificar a estrutura da escola pública básica, que permanece praticamente idêntica à que existia há mais de um século" (PARO, 2008, p.14).

Para Ghanem:

A aspiração a um "sistema escolar democrático" supõe que se admita a possibilidade
de democratizar organizações burocráticas. Essa possibilidade enfrenta o desafio de
contrariar as próprias características definidoras da natureza dessas organizações, o
que só seria consequente se simultaneamente se modificasse o modelo de educação
escolar ao qual aquele padrão de organização corresponde e que o põe em
funcionamento (GHANEM, 2000, p.148)

Em outras palavras, a participação dos sujeitos da comunidade escolar na construção de uma escola e sociedade democrática, ainda enfrenta os desafios da tradicional gestão burocrática no interior dessas instituições e dos sistemas educativos.

Seria preciso lançar um debate mais profundo sobre a gestão democrática do ensino e de como ela tem refletido nos sistemas escolares, o que significa recuperar o sentido da radicalidade política com que fora idealizada. A "radicalidade política da defesa da gestão democrática nasce atrelada a tensões sociais e políticas; quando delas se distancia, despolitizase e se torna gestão técnica e rotineira da máquina escolar”. (ARROYO, 2008, p.43)

De acordo com Paro (2008), compreender a escola como um grupo social, em que seu modo de operar, seus conflitos, expectativas e costumes compõem sua identidade para além do caráter institucional é assumir sua função social de formação para cidadania, no sentido de tomada de consciência crítica e participação popular.

Aos discursos participacionistas e de democratização da sociedade clamados pela sociedade civil organizada nos anos de 1980, contrapõe-se a Reforma do aparelho do Estado, redefinindo seu papel:ele deixa de ser concebido como provedor do bem-estar social para se tornar o regulador das políticas sociais.

Os termos passam a servir a projetos de sociedade distintos: aquele que mira a participação social como lugar de transformação do Estado e da sociedade e aquele que a compreende como minimização do Estado, com a transferência de responsabilidades à sociedade civil, sob a égide do neoliberalismo, em um cenário que Dagnino (2004) denomina de "confluência perversa".

A perversidade estaria colocada, desde logo, no fato de que, apontando para direções opostas e até antagônicas, ambos os projetos requerem uma sociedade 
civil ativa e propositiva. Essa identidade de propósitos, no que toca à participação da sociedade civil, é evidentemente aparente. Mas essa aparência é sólida e cuidadosamente construída através da utilização de referências comuns, que tornam seu deciframento uma tarefa difícil, especialmente para os atores da sociedade civil envolvidos, a cuja participação se apela tão veementemente e em termos tão familiares e sedutores. A disputa política entre projetos políticos distintos assume então o caráter de uma disputa de significados para referências aparentemente comuns: participação, sociedade civil, cidadania, democracia. (DAGNINO, 2004, p. 96-97). Grifos nossos

Para Arroyo (2008), os estudos que debatem a gestão democrática no interior das escolas, muitas vezes, não observam os limites para a participação num contexto de crescente fortalecimento dos seus órgãos de controle e decisão, conforme o modelo do Estado regulador. A participação dos membros da comunidade escolar na tomada de decisões e o desenvolvimento de sua autonomia passam a ser regulados, seja na delimitação de suas ações, quando as políticas educativas definem objetivos ou mesmo percursos formativos, seja quando avaliam os resultados das práticas pedagógicas desenvolvidas no interior das escolas.

Em relação aos sentidos de participação e democracia com que se engendram os sistemas de ensino e propostas pedagógicas, conferindo à escola o paradoxo da "autonomia controlada", Arroyo também questiona a necessária investigação sobre:

Quem são, a que grupos pertencem estes guardiões da democracia escolar e, sobretudo, a que projeto de sociedade, de escola, de docência serve seus controles da democracia escolar nascente. Que visão têm dos profissionais da escola básica, imaturos, incapazes de autogerir-se e gerenciar seu trabalho e instituição em que trabalham? Exatamente a visão oposta que o movimento docente pretendia afirmar: trabalhadores da educação capazes de autogestão (ARROYO, 2008, p. 44).

Há de se questionar ainda que sentidos a participação democrática tem assumido para os próprios membros da comunidade escolar, sobretudo, para os profissionais da educação. Seria ela mero discurso ou prática moralizante, "uma visão consciente de democracia e visão pacífica, não tensa, de poder?” (ARROYO, 2008, p. 45), ou tenderia à modificação das próprias práticas, tendo em vista as especificidades dos estudantes e o compromisso político com a transformação social?

Quando tratamos da educação de jovens e adultos no Brasil é necessário avaliar que nem mesmo o primeiro degrau da democratização do ensino tem se consolidado. Como apontamos, a questão do acesso às oportunidades educativas figura mais nos discursos políticos que em ações concretas, refletindo nos altos índices de analfabetismo e de pessoas que não concluíram o ensino básico.

Em relação à consideração dos sujeitos e sua participação no engendramento das 
propostas de ensino, constatamos distâncias ainda maiores entre a retórica e a prática. Dessa maneira, o sentido de qualidade social da educação fica refém de processos participativos regidos por controles burocráticos, muitas vezes reduzindo a participação à mera consulta aos educadores e educandos sobre decisões já tomadas.

São essas inquietações que permearam nossas análises, pressupondo que o princípio de gestão democrática poderia ter favorecido a constituição do Projeto CIEJA de modo mais aproximado às demandas dos educandos e educadores dos Centros através da participação dos gestores e educadores.

\subsubsection{Da análise dos documentos e entrevistas}

Observamos, até aqui, que a EJA se localiza num terreno que, embora instável, também é fértil para emergência de diferentes práticas de ensino. Os sentidos que lhe são atribuídos estão em disputa, ainda que pareçam consensuais devido à utilização de conceitos polissêmicos. Trata-se de uma crise discursiva como afirma Dagnino (2004).

É justamente através dos discursos que buscamos reconstituir a trajetória dos CIEJAs na cidade de São Paulo, considerando que eles "não são apenas (a não ser excepcionalmente) signos destinados a serem compreendidos, decifrados; são também signos de riqueza a serem avaliados, apreciados, e signos de autoridade a serem acreditados e obedecidos" (BOURDIEU, 2008, p. 53).

A riqueza dos signos estaria submetida ao mercado linguístico em que os discursos são anunciados. Para Bourdieu (2008), esse mercado é estabelecido pela relação de forças entre os locutores, remetendo à sua competência linguística e aos contextos em que os discursos são produzidos. A competência linguística diz respeito não só a uma competência técnica de manipulação da língua legítima ${ }^{10}$, como também à competência legítima, ou seja, o reconhecimento estatutário daquele que tem autoridade e crédito para emitir a palavra.

Nesse sentido, entre os discursos que engendram a implantação dos CIEJAs e possuem

\footnotetext{
10 A língua legítima, para Bourdieu (2008), é um único modo de expressão entre outros, que impõe sua legitimidade como produto da dominação política, a língua considerada oficial e reconhecida universalmente.
} 
reconhecimento geral, estão aqueles produzidos oficialmente pela SME e registrados em diversos documentos que tratam dos Centros. Aos documentos é atribuído o caráter de oficialidade e legitimidade para interpretar e implicar mudanças no mundo concreto, devido ao contexto de produção formal e autoridade dos locutores. Isso significa que os discursos oficiais não somente explicam a realidade e discorrem sobre diretrizes para as ações de SME, mas que sua própria produção cria determinada realidade e produz determinados efeitos sobre ela. Aquilo que os documentos discursam, em forma e conteúdo, é a representação que certo grupo (aquele que ocupa o poder no momento de sua realização) produz sobre um problema (qual seja a necessária adequação da EJA às condições e necessidades dos educandos) e a representação sobre quais seriam suas soluções.

Não queremos dizer com isso que se trate de algo meramente artificial, nem pretendemos cair em um relativismo que pouco nos auxiliaria a delinear nosso objeto de estudo, mas chamamos a atenção para o fato de que a produção dos discursos oficiais implica determinada leitura da realidade em detrimento de outras possíveis, ou seja, desfaz ao mesmo tempo em que emerge de possíveis conflitos entre conceitos distintos submersos nas mesmas palavras.

A ciência social lida com realidades já nomeadas e classificadas, portadoras de
nomes próprios e de nomes comuns, de títulos, de signos, siglas. Sob o risco de
retomar por sua conta, sem o saber, atos de constituição cuja lógica e cuja
necessidade ela ignora, a ciência social deve tomar como objeto as operações sociais
de nomeação e os ritos de instituição através dos quais elas se realizam. Contudo,
num nível mais profundo, a ciência social precisa examinar a parte que cabe às
palavras na construção das coisas sociais, bem como a contribuição que a luta entre
classificações, dimensão de toda luta de classes, traz à constituição das classes,
classes de idade, classes sexuais ou classes sociais, clãs, tribos, etnias ou naçôes.
(BOURDIEU, 2008, p. 81)

Assim, procuramos realizar nossa leitura dos documentos de maneira contextualizada, relacionando-os ao momento de produção e conflitos presentes. Vale observar que além das leis, decretos e portarias, com efeitos juridicamente determinados, recorremos também à leitura dos programas, projetos, orientações curriculares e planos de curso, a fim de compreender como se desenhavam as políticas e os CIEJAs entre as normas que o autorizam, regulamentam e regulam seu projeto. Aqui chamamos esse primeiro grupo de documentos legais, e o segundo de documentos pedagógicos, para facilitar nossa análise.

Notamos que grande parte dos enunciados aparece nos documentos legais após serem afirmados nos documentos pedagógicos, como a formulação dos Itinerários Formativos ou 
princípios do Projeto CIEJA, por exemplo. Porém, por vezes os enunciados presentes nos documentos legais são constituídos antes dos pedagógicos, é o caso das portarias que vêm determinar alguma especificidade decorrente do funcionamento da própria rede municipal de ensino ou pareceres do CME, entre outros.

Esse fato nos indicou que muitas das regulamentações ou regulações ${ }^{11}$ feitas provinham das ideias constantes nos documentos pedagógicos, tornando ainda mais relevante considerar o contexto em que o fizeram, seu reconhecimento e legitimidade. Como exemplo, podemos citar os pareceres do CME que geravam recomendações aos CIEJAs ou as portarias sobre o processo seletivo dos professores. Documentos que enunciam certa forma de ver e fazer proceder, legitimadas muito mais devido à sua forma legal, que propriamente por emanar de termos mais consensuais ou creditados pela comunidade que os recebia.

Buscamos, no entanto, desvelar os conflitos ao coletar e analisar os discursos daqueles que promoveram os documentos oficiais ou que tantas vezes foram seus receptores.

Optamos pela realização de entrevistas individuais e semiestruturadas ${ }^{12}$, por considerar que nos permitiriam atingir as tensões e vivências dos entrevistados naqueles momentos de elaboração e adaptação do Projeto CIEJA. As entrevistas também foram um instrumento privilegiado por considerarmos que a fala, diferentemente da escrita, que possui certo planejamento, dá margens à expressão mais espontânea sobre os acontecimentos. A entrevista semi-estruturada nos possibilitaria que se desenrolassem narrativas mais livres e se apresentassem os fatos e conflitos submersos nos documentos oficiais.

Sabe-se que o(a) entrevistador(a) realiza determinada violência simbólica ${ }^{13}$ em relação ao entrevistado, no entanto, procuramos minimizá-la com a organização de um roteiro que tocasse em questões essenciais ao nosso trabalho através da narrativa das entrevistadas. Essa escolha possibilitou que os fatos adentrassem nos discursos em determinada ordem e com determinado valor concebidos pelas entrevistadas e não devido à nossa intervenção, reduzindo os efeitos de autocensura. Limitamos nossa intervenção aos momentos de digressão alongados (em que procuramos reavivar o trajeto da memória que dava corpo à narrativa) ou a algum

\footnotetext{
11 A regulação tem o sentido de julgar como regulares ou irregulares as ações dos CIEJAs, enquanto a regulamentação define normas e diretrizes a serem seguidas.

12 Todas as entrevistadas subscreveram termos de consentimento livre e esclarecido (Anexo 2), e concordaram com a reprodução aberta e não anônima de seu depoimento.

13 Para Bourdieu (2008) a violência simbólica consiste na legitimação de uma relação de dominação pelos dominados, devido sua inscrição na história como algo natural.
} 
esclarecimento pontual sobre períodos ou pessoas envolvidas em certos contextos, de maneira que a entrevista se aproximasse de uma conversa. Seguimos, então, novamente a reflexão de Bourdieu (2008), que considera que o grau da tensão objetiva do mercado de trocas linguísticas depende do grau de oficialidade da situação da entrevista e da distância social entre entrevistador e entrevistado.

Minha posição como educadora do CIEJA Butantã favoreceu a entrevista com três das pessoas selecionadas, que por já serem conhecidas, tiveram maior disponibilidade e liberdade em expressar sua visão sobre os acontecimentos. Todas as entrevistadas foram previamente contactadas e informadas sobre o conteúdo da pesquisa, tendo sido bastante receptivas ao fato de poderem dar, de certa maneira, seu testemunho sobre os CIEJAs e sua vivência. Foi esse, então, o tom das entrevistas.

Entre as educadoras consultadas, constatamos trajetórias profissionais convergentes. Com exceção de Teresa Nori (do SENAC-SP), todas elas ingressaram na rede municipal de ensino como professoras, mesmo as que atualmente ocupam algum cargo de gestão (19891993). Notamos, ainda, que o início da atuação das entrevistadas na rede municipal de ensino coincide com a gestão de Luíza Erundina como Prefeita da Capital. Esse fator foi enfatizado quando relatavam sua trajetória, destacando a formação de professores da qual participaram, seja enquanto técnicas de DOT, seja enquanto docentes. Daí advém conceitos semelhantes em suas falas, remetendo aos discursos desse período, a que conferem uma legitimidade assentada tanto na própria experiência como no reconhecimento dos grupos.

Um ponto também comum entre seus relatos é que todas as entrevistadas já haviam trabalhado com a educação de jovens e adultos antes de integrarem os CIEJAs, cada qual desempenhando papéis e participando de propostas diferenciadas para a modalidade.

Outro fato relevante é que as posições das entrevistadas de SME na hierarquia da rede municipal são cambiantes, ora ocupam postos de chefia com mais autonomia, ora retornam ao magistério ou a posições em que respondem a "superiores" hierárquicos. Esses diferentes papéis acompanham e alimentam, no entanto, uma mesma personalidade e modos de ver as questões educacionais.

Além disso, notamos que algumas das entrevistadas trabalharam juntas na mesma unidade educacional, departamento ou ocasião e podem compartilhar, portanto, de concepções bastante similares que remontam sua experiência. 
Consideramos relevante questionar nas entrevistas e explicitar em nosso trabalho a trajetória profissional das entrevistadas como forma de obter um olhar mais contextualizado do lugar de onde falam a respeito do Projeto CIEJA. Suas experiências dialogam com as perspectivas educacionais expressas e permearam sua participação nos GTs, nos momentos de idealização e adaptações dos CIEJAs.

Coube-nos aferir, através das entrevistas os sentidos dessa participação para os diferentes profissionais, as tensões subjacentes aos consensos discursados, comparando-os com aqueles encontrados nos documentos.

\subsubsection{A análise de políticas públicas e o Modelo de Múltiplos Fluxos}

Segundo Souza (2006), a política pública pode ser definida como campo do conhecimento que busca, ao mesmo tempo, colocar o governo em ação e/ou analisar essa ação e, quando necessário, propor mudanças em seus rumos. A formulação de políticas públicas traduziria "propósitos e plataformas eleitorais em programas e ações que produzirão resultados ou mudanças no mundo real" (SOUZA, 2006, p. 26).

Entre as políticas distributivas estão aquelas que fornecem bens e serviços básicos à população, sendo frequentemente associadas ao termo "políticas públicas" as políticas sociais que:

Não são concessões de um em benefício do outro, mas uma correlação de forças divergentes que implicam negociações, e essas não se dão sem conflitos, pois estão em jogo interesses distintos, nos quais se pressupõe também um nível de conscientização que permita aos sujeitos desenvolver a cidadania em determinado momento histórico. (POSSANI, 2008, p.63)

Constituída como campo teórico nos Estados Unidos na década de 1930, a análise de políticas públicas procura compreender ou nortear a atuação do governo na tomada de decisões. Souza (2006) destaca que Hebert A. Simon fez contribuições relevantes ao campo no final da década de 1940, quando observou que os decisores públicos teriam sua atuação limitada devido a diversos fatores, como falta de informação, interesses em conflito, ou falta de tempo. Ele considerou ser possível a criação de estruturas que modelassem comportamentos a fim de atingir os resultados pretendidos (SOUZA, 2006, p. 23). Ainda na 
década de 1950, com o imperativo de melhorar a qualidade das políticas, surgiram estudos que buscariam, inclusive, o desenvolvimento de propostas e pesquisas que interferissem na tomada de decisão, divulgando aos agentes públicos informações e conhecimentos que subsidiassem as suas escolhas

Desde esse período, verifica-se que não apenas pesquisadores ligados às universidades desenvolvem trabalhos no campo de análise de políticas públicas, como também grupos de pesquisa ligados a instituições do governo buscam prescrevê-las para superar problemas de diversas ordens. Silva e Dagnino (2011) indicam que gradativamente há uma aproximação entre os dois grupos, em que analistas acadêmicos passam a influenciar decisões em âmbitos do governo e o contrário também pode ocorrer.

Segundo Barroso (2009), políticas também influenciariam a produção de pesquisas, através do controle de financiamento, de encomendas, do reconhecimento de mérito, da validação dos temas ou métodos. A crítica à visão mecanicista da "knowledge based policy" (política baseada no conhecimento) destaca que a escolha dentre a pluralidade de estudos, fontes, formas e conteúdos que geram conclusões e recomendações políticas é "pouco racional e fortemente condicionada por interesses e lógicas de poder" (BARROSO, 2009, p. 989).

Associa-se à quantidade e diversidade dos conhecimentos gerados pela pesquisa sobre políticas públicas o fato de que os "decisores" políticos nem sempre têm acesso direto a eles, mas àqueles selecionados por agentes intermediários (assessores, especialistas, entre outros). A relação entre os "conhecimentos" sobre determinado problema, suas possíveis soluções e as decisões políticas dependeriam, portanto, dos sujeitos envolvidos, suas relações de poder e contextos históricos.

Seja com o propósito de descrição e estudo das ações governamentais, seja com o objetivo de propor mudanças em seu percurso, o campo de estudo de análises de políticas públicas é multidisciplinar, propicia a visão integrada sobre os problemas e as relações entre Estado e sociedade.

A nossa opção pelo estudo da trajetória do CIEJA atende à recomendação de Barroso (2009) para adotar:

(...) uma visão mais plural e contextualizada, em que o conhecimento e a política são vistos como um processo; desenvolvem-se através das práticas e são constituídos e reconstituídos através das actividades de vários indivíduos e organizações, actuando de maneira diferente, mas em simultâneo. (BARROSO, 2009, p. 991) 
Importa-nos identificar na trajetória do Projeto CIEJA como se formulam os problemas, soluções e decisões que lhe dão corpo. Por isso, entre as diversas ferramentas existentes para análise de políticas, adotamos o Modelo de Múltiplos Fluxos (Multiple Streams), desenvolvido por John Kingdon (2003), que se ocupa de “dois processos 'prédecisionais' principais: a definição da agenda e especificação das soluções"14 (KINGDON, 2003, p.196). Este instrumento de análise permite que sejam aferidas as múltiplas relações de poder, a interação entre propostas e as estruturas administrativas e atuação de diferentes atores, internos e externos ao âmbito governamental, presentes no processo.

Para John Kingdon (2003) a política pública compreende quatro processos: a definição de agenda política; a identificação de soluções para a elaboração da política e avaliação dessas opções; a escolha dentre as soluções identificadas e avaliadas; e a implementação da política.O modelo de Fluxos Múltiplos debruça-se sobre a definição da agenda política, buscando compreender como um assunto passa a ser foco de atenção pública, como é configurado enquanto problema para que sejam selecionadas soluções.Considerando que existem inúmeras condições $^{15}$ (ou questões) a serem tratadas na sociedade, Kingdon aponta que muitas não chegam a mobilizar nenhum interesse de intervenção, enquanto outras chamam atenção do governo e são passíveis de serem focalizadas pelos formuladores de políticas, constituindo a agenda governamental.

Existe uma diferença entre uma condição e um problema. Nós deixamos de lado todos os tipos de condições todos os dias e elas não alcançam lugares de destaque nas agendas políticas. Condições são definidas como problemas e têm uma melhor chance de ascender à agenda, quando passamos a acreditar que devemos fazer algo para mudá-las (KINGDON, 2003, p.198). ${ }^{16}$

Conforme Kingdon (2003), existiriam diferentes motivos para as pessoas conceberem certas condições como problemas: primeiro, aquelas condições que violam valores sociais importantes; segundo, a comparação das condições entre diferentes países ou unidades relevantes; terceiro, sua classificação como uma categoria em detrimento de outras. Nesse último caso, podemos pensar no exemplo da educação de jovens e adultos, que pode ser

\footnotetext{
${ }^{14}$ Tradução nossa do original: "Two major pre-decision processes have occupied us: agenda setting and alternative specification".

${ }^{15}$ Traduzirmos o termo "condition" utilizado por Kingdon, como condição ou questão social.

${ }^{16}$ Tradução nossa do original "There is a difference between a condition and a problem. We put up with all kind of condition every day and conditions do not rise to prominent places on policy agendas. Conditions come to be defined as problems, and have a better chance of rising on the agenda, when we come to believe that we should to do something to change them".
} 
classificada como problema restrito à área da educação ou questão de direito.

Desse modo, dentre as condições ou questões que constituem a agenda governamental, apenas algumas seriam consideradas em situações específicas, compondo a agenda decisional, em que elas estariam preparadas para a tomada de decisão e formulação da política. Para compreender esse processo, Kingdon definiu que existem três fluxos decisórios (streams): problemas; soluções (alternatives) e políticas (policies).

O interesse dos agentes políticos em agir poderia ocorrer através da utilização de indicadores, eventos ou crises, ou por meio de "feedback" das políticas vigentes sobre determinadas condições. A forma como o problema é caracterizado e definido como integrante da agenda decisional implicaria na escolha das soluções disponíveis para sua resolução sendo, portanto, um fator fundamental para todo o processo de formulação da política.

Obviamente há agendas dentro das agendas. Elas variam de agendas altamente
gerais, como as listas de itens de que se ocupam o presidente e seu círculo imediato,
às agendas bastante especializadas, incluindo a agenda de subcomunidades, como as
de pesquisa biomédica ou transporte fluvial. Temas que não aparecem na agenda
geral podem estar bastante vivos nas agendas especializadas ${ }^{17}$. (KINGDON, 2003, p.
196)

No segundo fluxo, observam-se quais são as soluções ou soluções disponíveis para formulação da política e como são avaliadas para auxiliar a tomada de decisão sobre quais ações desenvolver. Os fluxos não são propriamente lineares, podendo desenvolver-se independentemente. São permeados por diferentes atores e interesses que influenciam os modos de ver, compreender e propor ações sobre problemas específicos.

Capella (2007) observa que para explicar como as soluções são constituídas, Kingdon aproxima-se do modelo de "Garbage can", desenvolvido na década de 1970 por Cohen, March e Olsen. Nesse modelo as decisões seriam elaboradas a partir de soluções já existentes que competem entre si, enquanto algumas são selecionadas outras seriam descartadas. Aponta-se, que muitas vezes as decisões políticas seriam construídas a partir das soluções disponibilizadas por diferentes organizações e não propriamente a partir dos problemas levantados. A sobrevivência dessas soluções, no "modelo da lata de lixo", estaria relacionada tanto a sua viabilidade de concretização, quanto da ação daqueles que as formularam.

\footnotetext{
${ }^{17}$ Nossa tradução do original "Obviously, there are agendas within agendas. They range from highly general agendas, such as the list of items occupying the president and his immediate inner circle, to rather specialized agendas, including the agendas of such sub communities as biomedical research or waterway transportation. Subjects that do not appear on a general agenda may be much alive on a specialized agenda."
} 
Kingdon (2003) observou também que as soluções e soluções seriam geradas por diferentes comunidades políticas ("policy communities"). Elas podem ser formadas por parlamentares, acadêmicos, funcionários públicos ou grupos de interesse. Embora nem sempre a comunidade compartilhe das mesmas crenças e dos mesmos valores, a partir das soluções consideradas consistentes, elas constituem ideias que são "amaciadas" ("soften up"), ou seja, buscam maior adesão em diferentes esferas. Essa difusão dependeria, no entanto, do seu acolhimento por diversas comunidades políticas e pela opinião pública, que podem restringir ou facilitar sua aceitação. Uma vez difundidas as ideias, progressivamente ganhariam força, aumentando as chances de as soluções e serem adotadas na formulação das políticas.

É importante notar que nesse processo, nem sempre as soluções são construídas em relação direta aos problemas, as comunidades podem primeiro criar soluções para depois procurar os problemas a que corresponderiam. Nesse sentido, os sujeitos que atuam no processo de formulação e difusão dessas soluções adquirem grande importância.

A mudança na agenda governamental ainda seria influenciada pelo fluxo da política. Nele, não são propriamente as ideias construídas que influenciam o processo de reconhecimento dos problemas ou escolha de soluções, mas as negociações políticas, o clima ou humor nacional ("national mood”), a força dos grupos políticos ou as mudanças de governo. O humor nacional seria transitório e formado por um grande número de pessoas que compartilham da mesma ideia em certo momento. Ao mesmo tempo em que determinada questão pode adentrar a agenda governamental devido ao "clima" ou humor nacional, ele também pode bloqueá-la.

Do mesmo modo, os grupos políticos organizados, apesar de nem sempre serem determinantes para que questões específicas atinjam a agenda governamental, podem atuar como facilitadores ou bloqueadores, cabendo aos formuladores de política avaliar os conflitos e consensos presentes, as vantagens e desvantagens em considerar determinada questão.

A mudança de governo ("turn over") teria como consequência a mudança de diversos sujeitos, não só aqueles participantes do sistema eleitoral, como também funcionários em posições estratégicas. Esse momento possibilitaria o abandono ou inserção de novas questões na agenda governamental. Além disso, com a mudança de governo, mudam também as relações entre diferentes setores, estabelecendo um novo cenário de disputa acerca das questões a serem consideradas na agenda, ficando muitas delas restritas a certos setores. 
Segundo o Modelo de Múltiplos Fluxos, as mudanças nas agendas políticas podem acontecer quando há a convergência ("coupling") dos três fluxos (de problemas, alternativas ou soluções e de política), que constituem oportunidades ("policy windows") para que questões e soluções ascendam à agenda governamental.Essas oportunidades, no entanto, são transitórias e podem ser aproveitadas ou desperdiçadas pelas comunidades políticas ou pelos chamados empreendedores de política ("policy entrepeneurs") e aqueles que advogam promovendo determinadas soluções ou problemas ("advocates").

Os empreendedores de política seriam indivíduos que representariam diferentes comunidades políticas, possuindo certo trânsito na esfera governamental capaz de difundir determinadas questões ou propostas (CAPELLA, 2007, p.31). De acordo com Kingdon:

\begin{abstract}
A janela política é uma oportunidade para os advogados das propostas impulsionarem suas soluções ou para chamarem a atenção para seus problemas específicos. (...) Os advogados ficam à espreita em torno do governo com suas soluções a mão, a espera dos problemas que flutuam em seu entorno e podem juntar-se às suas soluções, à espera do estágio do fluxo político que podem usar em sua vantagem. Às vezes, a janela abre de modo bem previsível. A renovação planejada de um programa, por exemplo, cria na oportunidade para muitos participantes impulsionarem o seu projeto ou preocupação. Outras vezes, isso é bastante imprevisível ${ }^{18}$ (KINGDON, 2003, p.165).
\end{abstract}

De fato, todos os fluxos estão também relacionados a uma série de sujeitos que contribuem para identificação dos problemas, formação e seleção de soluções. Eles podem pertencer ao âmbito interno ou externo ao governo. Kingdon (2003) aponta, ainda, que existem atores "visíveis" e "invisíveis" durante todo o processo. Entre os atores "visíveis" estariam o chefe do poder executivo e os ocupantes de altos postos da administração pública, os membros do Poder Legislativo, grupos de interesse, mídia e opinião pública, que receberiam a atenção da imprensa, podendo exercer maior ou menor influência na definição da agenda governamental, tendo maior atuação no fluxo dos problemas e de políticas. Os atores "invisíveis" - acadêmicos, funcionários públicos, analistas de grupos de interesse, assessores parlamentares, pesquisadores e consultores - teriam mais influência na geração e escolha das soluções, ou seja, na agenda de decisão. (CAPELLA, 2007, p.31).

\footnotetext{
18 The policy windows is an opportunity for advocates of proposals to push their pet solutions, or to push attention to their special problems. (...) Advocates lie in wait in and around government with their solutions at hand, waiting for problems to float by to which they can attach their solutions, waiting for a development in the political stream they can use to their advantage. Sometimes, the window opens quite predictably. The scheduled renewal of a program, for instance, creates na opportunity for many participants to push their pet project or concern. At other times, it happens quite unpredictable.
} 
Pelo exposto, o Modelo de Múltiplos Fluxos nos oferece um instrumento de análise que possibilita uma visão multidimensional da trajetória dos CIEJA enquanto umas das alternativas das políticas para EJA em São Paulo. 


\section{POLÍticas PÚBLICAS DE EJA EM SÃO PAULO}

Ao longo das duas últimas décadas foram implementadas no município de São Paulo diferentes propostas direcionadas à educação de jovens e adultos, que indicam "um permanente começar e recomeçar de programas, marcados por políticas de determinados partidos e governos, que acabam por provocar descontinuidade na oferta de um nível de estudo para outro" (SPÓSITO et. al., p. 15, 2005). O quadro a seguir poderá auxiliar na localização de diferentes modos de organizar a oferta municipal de educação de jovens a adultos nesse período.

\section{Quadro 1 - Modalidades de organização da EJA na Secretaria Municipal de Ensino de São Paulo entre 1989 e 2009}

\begin{tabular}{|c|c|c|c|}
\hline Luíza Erundina (PT) & $\begin{array}{c}\text { Paulo Maluf/ Celso } \\
\text { Pitta (PFL) }\end{array}$ & Marta Suplicy (PT) & $\begin{array}{l}\text { José Serra (PSDB) } \\
\text { Gilberto Kassab (DEM) }\end{array}$ \\
\hline 1989-1992 & $1993-2000$ & 2001-2004 & $2005-2009$ \\
\hline $\begin{array}{l}\text { > EMPSG } \\
\text { * EDA migra da } \\
\text { SEBES para SME }\end{array}$ & > EMPSG & > EMEF & > EMEF \\
\hline$>$ MOVA & $>$ Proalfa & $>$ MOVA & $>$ MOVA \\
\hline$>$ CEMES & $>$ CEMES & $>$ CIEJAs & > CIEJAs \\
\hline $\begin{array}{l}>\text { Frente do } \\
\text { Funcionalismo }\end{array}$ & $\begin{array}{l}>\text { Telecurso e } \\
\text { CMTC }\end{array}$ & > СMTC & > СMTC \\
\hline
\end{tabular}

A descontinuidade das propostas de ensino não significa a descontinuidade das ideias ao longo da história. Ao contrário, elas coexistem e estiveram em disputa em cada governo, por isso são abandonadas, transformadas, recuperadas ou mantidas.

O desafio a que nos lançamos nesse capítulo foi, justamente, de reconhecer, entre as políticas de EJA no município de São Paulo (de 1989 e 2009), as concepções educacionais e escolhas do poder público que contribuiriam para o desenho do modelo dos CIEJAs. Para tanto, trataremos, em cada período da configuração dos problemas, soluções e sua confluência em determinados contextos.

Nosso recorte histórico a partir de 1989 deve-se a dois fatores: o marco legal, em que a EJA tem oferta garantida pela Constituição Federal de 1988, e a transição do Programa de Educação de Adultos da Secretaria do Bem-Estar para a Secretaria Municipal de Educação 
em 1989. Foi também nesse período que se idealizaram os Centros Municipais de Ensino Supletivo (CEMES), que mais tarde seriam transformados em CIEJAs. Já 2009 foi o ano em que o CME aprovou o Novo Projeto CIEJA, redigido pelo coletivo de equipes técnicas dos Centros, viria a basear as diretrizes para o funcionamento dos CIEJAs postas na Lei 15.648/12.

\subsection{Gestão de Luíza Erundina (PT) - de 1989 a 1993}

A eleição de Luíza Erundina (PT) como prefeita de São Paulo em 1989 foi um marco significativo para o Partido dos Trabalhadores (PT), nascido em 1981, atuante nas campanhas pelas eleições diretas até 1984 e na elaboração da Carta Constitucional de 1988. Sua vitória sobre o candidato Paulo Maluf, do Partido Democrático Social (PDS), que estivera à frente das pesquisas durante o período eleitoral em 1988, foi permeada de expectativas de diferentes setores da sociedade que buscavam maiores espaços de participação na gestão do município e a ruptura com as prioridades das gestões anteriores.

Luíza Erundina, assistente social que teve sua trajetória política associada aos movimentos populares, enfatizava, durante a campanha eleitoral em 1988, as propostas de descentralização da administração pública, democratização da gestão e fortalecimento da participação popular. Suas propostas convergiam ao ambiente de democratização da sociedade no período posterior à promulgação da Carta Magna (1988).

As políticas de seu governo seguiram os planos anunciados na campanha eleitoral. Nesse sentido, de acordo com o artigo 77 da Lei Orgânica Municipal de 4 de abril de 1990, foi estabelecido que a Administração Municipal seria exercida, em nível local, pelas Subprefeituras.

Fomentou-se, também a criação de espaços participativos de incidência no orçamento público e nas políticas setoriais. Formaram-se os Conselhos da Saúde, da Criança e Adolescente, Educação, Habitação, Abastecimento, Cultura, Transporte, Idosos e Deficientes, através dos quais a sociedade civil poderia participar da elaboração de diretrizes, planos setoriais e avaliação das políticas (ABBONÍZZIO, 2007, p.33). 
No âmbito educacional, a nomeação do Professor Paulo Freire como Secretário Municipal de Educação (cargo que exerceu entre 1989 e 1991) reforçava as expectativas por mudanças e participação popular de diferentes comunidades políticas. A vivência do educador e sua influência nos movimentos de cultura popular na década de 60 contribuíam para inclusão da EJA na agenda das políticas públicas de educação. A carta escrita por Freire aos profissionais da educação, após tomar a posse do cargo, e a proposta político-pedagógica da "Escola Democrática" deram a tônica às ações educativas na cidade.

Entendemos que é a falta de participação nas decisões que muitas vezes leva ao
desânimo e à descrença em relação à escola. Pretendemos implantar os Conselhos de
Escola, fortalecer os Grêmios Estudantis e rever o papel das APMs - Associações de
Pais e Mestres. Pretendemos substituir gradativamente a atual função de controle
burocrático das DREMs -Delegacias Regionais de Ensino - por Núcleos de Ação
Educativa (NAEs), rompendo uma estrutura hierárquica de tomada de decisões
sustentada de cima para baixo e substituindo por instâncias de assistência,
acompanhamento e planejamento participativo da atividade pedagógica. A população
organizada - Conselhos Populares - cumpre melhor a função fiscalizadora das
DREMs. (...) A escola é também um espaço de organização política das classes
populares. A escola como um espaço de ensino-aprendizagem será então um centro
de debates de idéias, soluções, reflexões, onde a organização popular vai
sistematizando sua própria experiência. (SME, 1989, p. 6-8).

O excerto acima remete à importância da participação da sociedade civil. Ele convoca os educadores da rede municipal a integrarem a construção da escola pública popular, mirando o educando enquanto sujeito de sua formação.

Ao mesmo tempo em que se respondia ao "clima" de abertura de espaços de participação e democratização das instituições de determinados setores da sociedade, o Professor Paulo Freire e sua equipe inspiravam-se nas experiências dos movimentos de cultura popular da década de 1960 para formular alternativas aos problemas da educação municipal e democratização das escolas. Essas alternativas contrariavam a educação bancária, de transmissão verticalizada dos conhecimentos e cultura selecionados pela elite, apoiavam-se na valorização da cultura popular e na participação ativa da comunidade nos espaços educativos. A carta de Paulo Freire também apresentava o compromisso daquela gestão com um projeto político pedagógico emancipador.

Em 1989, a constatação da situação precária da rede em termos de infraestrutura e de condições de trabalho dos docentes eram indicadores que se somavam às vozes pela melhoria da escola pública. Em 1987, a greve dos funcionários da Secretaria Municipal de Educação já apontava esses fatores. No entanto, a mobilização desses profissionais sofreu um impacto negativo com a demissão dos grevistas no governo de Jânio Quadros do Partido Trabalhista 
Brasileiro (PTB). Para estruturar o diálogo com a categoria docente e demais funcionários da SME, o governo de Luíza Erundina, ao lado da reintegração dos profissionais demitidos em decorrência da greve de 1987, reconheceu o caráter burocrático e centralizador de SME, manifestando a intenção de gradativamente ampliar a autonomia local através dos Núcleos de Ação Educativa (NAEs).

A chamada de Freire aos docentes e profissionais da educação inaugurava uma proposta político-pedagógica que anunciava uma "nova qualidade" de ensino, que concebia a escola como centro de encontro, sistematização e difusão do saber. A administração de Paulo Freire na Secretaria Municipal de Educação (1989-1991), seguindo os eixos da gestão de Luíza Erundina na cidade, propôs como objetivos a participação, a descentralização e autonomia das unidades de ensino a partir de quatro prioridades: Democratização do Acesso; Democratização da Gestão; Nova Qualidade de Ensino; Alfabetização de Jovens e Adultos (SME, 1992, p.5).

O Conselho de Escola seria uma das alternativas para criação de espaços de diálogo com a comunidade e poderia orientar o trabalho das unidades educacionais. Pretendendo-se respeitar as características de cada escola e comunidade, sem que isso significasse seu isolamento ou a desarticulação entre elas, os Conselhos Regionais de Conselhos Escolares (CRECEs) favoreceriam a constituição de um espaço para troca de experiências e identificação de prioridades comuns de uma mesma região.

A Constituição de 1988, que incluía entre os direitos do cidadão, o direito ao ensino fundamental, obrigatório e gratuito, "inclusive para os que a ele não tiveram acesso na idade própria" (BRASIL, 1988), amparava e influenciava o estabelecimento da Democratização do Acesso e Alfabetização de Jovens e Adultos como duas das prioridades daquela gestão. Elas contribuíam para se incluir na agenda política uma parcela da população tantas vezes deixada à margem no passado.

Quando Paulo Freire assumiu a SME, numerosas práticas de educação de jovens e adultos vinham sendo desenvolvidas há algumas décadas por diversas organizações populares, como as Comunidades Eclesiais de Base, as Pastorais Operárias e de Direitos Humanos, Movimentos Sindicais, entre outras. Diversas dessas organizações sofreram o impacto direto do cancelamento de recursos da Fundação Educar nos anos finais de sua existência. Herdeira das ações do governo federal junto ao Movimento Brasileiro de 
Alfabetização (MOBRAL), a Fundação Educar passava a dispor de recursos limitados para as ações de alfabetização de adultos, tendo sido extinta em 1990, no governo de Fernando Collor de Mello (PONTUAL, 1996). O cenário encontrado pela SME na cidade em 1989 apresentava, então, poucas organizações sociais com cursos estruturados ou recursos para promover a alfabetização de jovens e adultos, mas com experiências acumuladas nesse campo que também iriam compor as alternativas para oferta de EJA. Além do Programa de Educação de Adultos $(E D A)^{19}$, vinculado à Secretaria do Bem-Estar Social (SEBES) que realizava alfabetização e pós alfabetização, a rede municipal mantinha o Ensino Regular Noturno e a Suplência ${ }^{20}$ II nas Escolas Municipais de Ensino Supletivo.

A SME avaliou que em grande parte das vezes esses cursos mimetizavam ou recortavam arbitrariamente o currículo do ensino diurno dirigido às crianças, e seus atendimentos eram insuficientes para suprir a demanda de 1,5 milhão de analfabetos na região metropolitana de São Paulo. Apontava-se, então, divergências em relação aos sentidos de "qualidade da educação". Para delinear o problema da EJA na cidade, apontava-se que:

Os cursos de Suplência I (antigo Programa de Educação de Adultos da Sebes) guardavam ainda o caráter de campanha, que se manifestava na precariedade dos locais de funcionamento, orçamento reduzido e escasso investimento na reposição e formação de profissionais. Por outro lado, na rede municipal, o ensino regular noturno e a Suplência II encontravam-se apartados, não havendo qualquer trânsito entre as duas modalidades. (SME, 1992, p.11)

Além do grande número de escolas da rede ociosas no período noturno $(58,25 \%)$ e altos índices de evasão e repetência, apresentava-se que os professores não "dispunham de orientação para realizar um trabalho diferenciado com esse alunado, parcela significativa dos funcionários públicos era analfabeta ou possuía reduzida escolaridade”. (SME, 1992, p.1113). De fato, as constatações iam ao encontro de uma realidade já reconhecida por diferentes grupos da sociedade civil, os indicadores negavam os sentidos de qualidade e democratização tal qual nos paradigmas da educação popular, que o próprio Paulo Freire há muito apontava. Para equacionar as problemáticas levantadas, a política para EJA na gestão de Erundina (1989-1993) definiu, então, as seguintes medidas e recomendações:

- que essas modalidades de ensino fossem encaradas como prioridade, por meio de ações sistemáticas e não apenas por campanhas de caráter transitório e emergencial; - a imediata incorporação à Secretaria Municipal de Educação (SME) do Programa

\footnotetext{
${ }^{19}$ O EDA correspondia ao primeiro segmento do ensino fundamental, teve origem no Mobral/Educar, em que adquiriu a feição compensatória, com docentes que não necessariamente tinham formação pedagógica.

${ }^{20}$ Utilizamos o mesmo termo encontrado nos documentos de SME, em que "Suplência" equivalia aos cursos de $1^{\circ}$ e $2^{\circ}$ Graus, voltados para jovens e adultos.
} 
de Educação de Adultos (equivalente à suplência I), até então subordinado à Secretaria do Bem-Estar Social (Sebes);

- extinção imediata da rede paralela de Escolas de Ensino Supletivo (EMES), criada a partir de 1976 e substancialmente ampliada na gestão de Jânio Quadros;

- incorporação das iniciativas e experiências da sociedade civil;

- organização de uma campanha de arregimentação de alfabetizandos, alfabetizadores e de salas de aula para jovens e adultos junto a sindicatos e entidades dos movimentos populares. (SME, 1992, p.7-8)

A primeira proposta relacionava-se ao caráter de campanha conferido às ações do Programa EDA e à inadequação das práticas educativas nas EMES. Ela marcava uma mudança de concepção sobre a EJA, daquela compensatória, para "educação pública popular", em que se propunha a "escola competente, aberta, flexível, criativa e crítica, que responda aos interesses das classes populares" (SME, 1992, p.11).

As medidas anunciadas respondiam também à necessidade de articular as ações de SME para jovens e adultos, que estariam apartadas. Destaca-se a transformação do Setor Supletivo em "Divisão de Orientação Técnica de Adultos", encarregada de integrar as inciativas da rede. As EMES constituiriam espécie de "rede paralela" (SME, 1992, p.8) da EJA, indicava-se, portanto, a necessária incorporação dessas unidades às Escolas Municipais de $1^{\circ} \mathrm{Grau}^{21}$.

Durante a transição do EDA da Secretaria do Bem-Estar Social para SME, havia o debate entre aqueles que temiam que a alfabetização de jovens e adultos nas escolas fosse desenvolvida segundo um modelo de reprodução do ensino voltado para crianças, e aqueles que defendiam sua incorporação nas escolas reafirmavam o direito à educação em ações mais abrangentes e não assistencialistas, articuladas a outros níveis de escolaridade no Sistema Municipal de Ensino. (ABBONNÍZIO, 2007).

O debate incorporava, de um lado, as vozes dos que acumulavam experiências junto à educação de adultos nas iniciativas da sociedade civil organizada e, de outro, a crítica ao caráter assistencialista que as mesmas poderiam assumir quando vinculadas às políticas emergenciais ou compensatórias, assumindo o caráter de campanha; apontavam a necessidade de concebê-las enquanto direito.

Em meio a esses debates, formou-se um Grupo de Trabalho Intersecretarial responsável pela transição do Programa EDA da SEBES para SME, contando com a participação de técnicos das duas secretarias, técnicos da Educação de Adultos no Sindicato

\footnotetext{
${ }^{21}$ Nomenclatura que designava o Ensino fundamental à época.
} 
do Funcionalismo Público e assessores oriundos de organizações não governamentais- Centro de Educação Popular do Instituto Sedes (Cepis), Centro Ecumênico de Documentação e Informação (Cedi) e Vereda. Destaca-se a participação de Vera Barreto na sistematização dos cadernos de EJA desse período.

Esse GT,que ficou conhecido como“GT da passagem”, foi responsável pela organização do Simpósio São Paulo - 1989: educar adultos para quê? (SME, 1992, p.9), que desencadeou uma série de discussões que difundiam as alternativas para EJA escolhidas por SME e buscavam adesão em meio aos debates, ou seja, conferir-lhe legitimidade não só pela via da autoridade de governo, mas também pelo reconhecimento de suas ideias junto aos interlocutores.

O GT também atuaria na transição do EDA. Destaca-se a instalação do Curso Especial de Habilitação para o Magistério, destinado aos monitores de educação de adultos sem formação docente. "Os técnicos da SEBES puderam optar pela secretaria em que permaneceriam e aqueles que optaram pela SME foram lotados nos Núcleos de Ação Educativa (NAEs) no cargo de assistente técnico de educação de adultos” (SME, 1992, p.10). Algumas classes de EJA isoladas, que se localizavam em Centros comunitários, ficaram vinculadas às Escolas Municipais de Primeiro Grau (EMPG) próximas; outras, sob supervisão dos técnicos lotados nos NAEs.

O MOVA foi uma das iniciativas de EJA em São Paulo que, nascida da participação e parceria com a sociedade civil organizada, inclusive com aquelas organizações, então, desamparadas financeiramente pela Fundação Educar, buscava atender às especificidades dos educandos segundo o paradigma da Educação Popular.

O objetivo do projeto MOVA é possibilitar ao educando jovem e adulto o processo construtivo de ampliação do próprio conhecimento. Isto implica no acesso a níveis cada vez mais elaborados do saber discursar, saber ler, saber escrever, teorizar, contar, resolver situações matemáticas, vivenciais, pesquisar as informações técnicocientíficas indispensáveis à compreensão do ser humano e à realidade social. É fundamental que esse saber humano seja voltado para a leitura crítica do mundo e para a apropriação e criação do conhecimento que melhor capacitem o sujeito à ação transformadora sobre a realidade social. (SME, 1990, p. 22)

A Frente do Funcionalismo era uma das prioridades da política de SME e de recursos humanos da administração municipal. Os dispositivos da Constituição Federal (1988) e a Lei Orgânica do Município demandavam que os funcionários municipais fossem concursados, no entanto, muitos deles eram analfabetos ou possuíam baixa escolaridade, assim, não possuíam 
os requisitos mínimos de escolaridade para se submeterem aos concursos.

A Frente do Funcionalismo buscaria promover a escolarização básica desses funcionários, tendo como objetivos "o resgate da cidadania dos servidores públicos, sua valorização profissional e a melhoria da qualidade de atendimento à população usuária dos serviços municipais" (SME, 1992, p.32). Os cursos eram organizados privilegiando-se o uso do próprio local de trabalho dos trabalhadores-estudantes, eram planejados pelas secretarias e órgãos aos quais eles se vinculavam e pelos NAEs, buscando-se a integração entre a escolarização básica e as especificidades do trabalho desenvolvido pelos educandos. $\mathrm{O}$ atendimento aos servidores na Frente do Funcionalismo abarcou as Secretarias das Administrações Regionais, da Cultura, do Bem Estar Social, da Saúde, a Companhia Municipal de Transportes Coletivos e o Serviço Funerário Municipal, chegando a atingir dois mil alunos por semestre (SME, 1992, p.37).

O documento "Reorientação Curricular do Ensino Noturno" (SME, 1992) traz o relato de experiência da Frente do Funcionalismo na Secretaria de Saúde, que revela a menor evasão desses núcleos que em outros cursos supletivos. Esse fator é justificado pelo perfil dos educandos, apesar das dificuldades de conciliarem trabalho e estudos, demonstravam "consciência de seu valor profissional" e estabeleciam "uma relação horizontal com o professor, pois ambos são funcionários públicos” (SME, 1992, p.36). Apontava-se que o horário de reunião coletiva semanal de professores favorecia a organização do trabalho e maior apropriação do Projeto. Além disso, as chefias dos funcionários-estudantes avaliavam positivamente seu desempenho profissional após frequentarem os cursos, revelando que passaram a ter "uma liderança natural perante os colegas", "facilidade de compreensão, de comunicação verbal e maior clareza na elaboração de relatórios", "posturas mais colaborativas e responsáveis". As experiências na Frente do Funcionalismo enriqueceram as discussões sobre currículo dos estudantes jovens e adultos trabalhadores nas EMEFS.

No Ensino Regular Noturno e Suplência I e II, após o Seminário "Repensando o Ensino Noturno" em 1990, desencadeou-se o Projeto "Repensando a Escola para o Jovem e Adulto Trabalhador", que compreendia o "Movimento de Reorientação Curricular do Ensino Noturno" e a "Formação Permanente do Educador".

O Movimento de Reorientação Curricular articulava-se segundo dois eixos: Projeto Ação Pedagógica pela Via da Interdisciplinaridade (Projeto Inter) e Projetos Alternativos 
propostos pelas escolas.

O "Projeto Inter" previa a coleta de dados sobre as comunidades escolares, o estudo sobre os dados coletados, o círculo de investigação temática com a participação dos educandos e seus responsáveis, a seleção e articulação dos temas geradores com as áreas de conhecimento, até o trabalho com os professores nas salas de aula, que remetiam à metodologia de trabalho dos Círculos de Cultura propostos por Freire nos movimentos de educação e cultura popular dos anos 60 (BARRETO, 1992).

A adesão ao Projeto Inter não era obrigatória, buscando-se respeitar a autonomia das escolas em selecionar conteúdos curriculares e a metodologia de ensino. Apostando nesta autonomia das escolas, fomentaram-se a elaboração de projetos próprios por cada unidade escolar, os Projetos Alternativos, visando-se o desenvolvimento de ações educativas mais comprometidas e adequadas a sua realidade.

Estava em pauta, então, a reflexão sobre os conteúdos curriculares selecionados pelas unidades de ensino em relação aos estudantes que elas atendiam, aos seus interesses, suas condições de aprendizagem, seu conhecimento acumulado, além da maneira de gerir a escola, enquanto espaço público e democrático, segundo as prioridades estabelecidas por aquela gestão e que citamos anteriormente.

Não acreditamos em receitas, em teorias desvinculadas de ações concretas, em "pacotes pedagógicos" elaborados longe da escola. Nossa crença é de que a partir da reflexão e do trabalho coletivo, os educadores encontrarão caminhos para a construção de um novo modelo de escola pública. Aquele que levará em conta o cansaço ou a fome desta população que chega a ela. (BARRETO apud SME, 1991, p.3)

O desafio era que se repensasse os propósitos educacionais definidos e caminhos escolhidos, que se possibilitasse aos educadores a atuação sobre seu contexto social, em vez de sua mera conformação ao mesmo. Era preciso, então, identificar e analisar as características e problemáticas da comunidade escolar, planejar ações para melhorá-las coletivamente, ou seja, era preciso propor mudanças.

As soluções para efetuar essas mudanças foram discutidas e difundidas às escolas através da formação dos educadores, permeada pelo paradigma da Educação Popular que redimensionava a concepção sobre os sujeitos do processo educativo e de construção do conhecimento, segundo as quais se pretendia "formar o homem livre e transformador" (SME, 1991, p.16). 
Preconizava-se a importância do diálogo e trabalho coletivo; de uma visão dialética sobre a construção do conhecimento, não sua fragmentação; do respeito à identidade e especificidades dos educandos.

A "Formação Permanente dos Educadores" na EJA foi sistematizada em uma série de quatro cadernos, cada qual correspondente a uma fase da implementação da política de EJA na cidade.

O Caderno de Formação "Construindo a Educação do Jovem e Adulto Trabalhador 1" (SME, 1990), condensava as reflexões do Simpósio "São Paulo 1989 - Educar Adultos para quê"? Trazia a proposta da SME para a EJA; firmava a importância da adequação dos cursos à identidade dos educandos; criticava e buscava superar a concepção compensatória da modalidade e convidava os educadores a identificarem problemáticas em seu cotidiano que dificultavam o trabalho pedagógico e que a escola favorecesse o acesso e permanência dos estudantes.

O Caderno de Formação Construindo a Educação do Jovem e Adulto Trabalhador 2" - Reorientação do Ensino Noturno - "Diretrizes para elaboração de projetos pelas escolas" (SME, 1991) trazia, então, a identificação de problemas estruturais, organizacionais e pedagógicas levantados pelas escolas e indicação de possíveis soluções. Elas foram desenvolvidas nos Projetos Alternativos para EJA.

Os apontamentos relacionados à estrutura tratavam do enriquecimento do currículo, que ofereceria pouca flexibilidade para realização dos cursos, além da reprodução do currículo do ensino diurno, que não dialogava diretamente com as necessidades dos educandos jovens e adultos. Eles reconheciam também a dificuldade dos estudantes trabalhadores frequentarem a escola assiduamente e por tantas horas diárias. Propuseram-se, então, soluções como a alteração da duração do curso com diminuição da carga horária diária e ampliação dos anos ou semestres; a organização de módulos semestrais; trabalho polivalente ou semipolivante para uma ou mais séries ou termos; substituição ou adição de matérias no currículo mais adequadas às expectativas e necessidades dos educandos.

No aspecto organizacional, houve a indicação da dificuldade dos alunos acompanharem tantas disciplinas em um mesmo dia de aula e a necessidade de diversificar os espaços educativos na escola como forma de dinamizar o processo ensino-aprendizagem. Observou-se que a organização da escola, em termos de tempos e espaços, deveria servir à 
proposta pedagógica e não o contrário. Apresentaram-se como soluções a programação de aulas mais longas, duplas ou triplas, condensando uma ou duas disciplinas por dia letivo; permitir a entrada de alunos após o horário fixado; reorganizar o horário de trabalho docente ou ainda pagar horas de trabalho excedente para estudo e participação dos professores em projetos diversificados; reorganizar o horário de merenda da escola, de modo a oferecê-la aos estudantes do período noturno.

Diante dos problemas de natureza organizacional verificava-se como solução a disponibilização de um "professor volante", com horas de aula excedentes para cobrir as eventuais faltas dos docentes ou programar projetos, a flexibilização do horário de entrada, servindo o jantar no início das aulas, oferecendo-se atividades diversificadas em turmas multisseriadas ou plantão de dúvidas nas primeiras aulas.

No aspecto pedagógico, após considerar as especificidades dos educandos e a necessidade de atrelar o ato educativo à sua realidade, sugere-se a reorganização do programa de ensino a partir do estudo do meio; integração entre áreas de conhecimento, envolvendo diferentes componentes curriculares, atividades e projetos diversificados a partir de temas geradores e rever os métodos de avaliação.

Algumas escolas implementaram a dupla docência e incorporaram atividades culturais e esportivas às horas de estudo. Constatou-se também a dificuldade de empreender o trabalho coletivo nas unidades educacionais, devido à impossibilidade de reunir os professores em um mesmo horário. Diante desse problema, algumas escolas organizaram grupos e subgrupos que semanalmente ou quinzenalmente reuniam-se para estudo e planejamento e organização das atividades dos projetos.

Esse conjunto de alternativas estruturais, organizacionais e pedagógicas nortearam as discussões nas unidades escolares para que compusessem os próprios Projetos Alternativos para a educação de jovens e adultos trabalhadores. O Caderno de Formação “Construindo a Educação do Jovem e Adulto Trabalhador 3, Construindo um novo Ensino Noturno Sistematização dos Projetos Elaborados pelas Escolas (SME, 1992), fez um balanço das ações empreendidas até 1992 e demonstra a pluralidade nas escolhas dessas possíveis soluções pelas escolas.

O documento apresenta, ainda, a recomendação de implantação de um Centro Municipal de Ensino Supletivo, cuja proposta reunia as soluções sugeridas para e pelas 
escolas:

Tivessem sido mantidos apenas os programas escolares convencionais, diversos grupos de jovens e adultos trabalhadores não teriam alcançado as oportunidades de escolarização que lhes foram asseguradas pela flexibilidade das alternativas oferecidas. Neste sentido, recomenda-se preservar a orientação de desenvolver alternativas diversificadas de atendimento às especificidades da demanda, buscando sempre maximizar os recursos materiais, humanos e os equipamentos existentes. Entre outras alternativas ainda não exploradas, seria conveniente dar seguimento à implantação do Centro Municipal de Ensino Supletivo (CEMES) (SECRETARIA MUNICIPAL DE EDUCAÇÃO, 1992, p. 45)

O projeto do CEMES foi elaborado ao final da gestão, após a saída de Paulo Freire do cargo de Secretário Municipal de Educação, substituído por Mario Sergio Cortella ${ }^{22}$.

A proposta foi aprovada pelo Conselho Estadual de Educação em 18 de novembro de 1992, pretendendo alcançar maior flexibilização dos tempos e espaços de estudo para jovens e adultos trabalhadores que não conseguiam frequentar as escolas nos moldes oferecidos na rede.

Com a integração do programa de Educação de Adultos (EDA) na Rede Municipal de
ensino verificou-se um aumento de solicitações para atendimentos especiais. Ou seja,
grupos específicos de trabalhadores que necessitam do $1^{\circ}$ grau, mas não têm
possibilidade de frequentar a escola diariamente e nem de cumprir a carga horária
que a escola exige. Foi pensando nesses trabalhadores e num atendimento adequado
que nasceu a proposta dos Centros Municipais de Ensino Supletivo (CEMES). Os
Centros vêm dar autonomia pedagógica e administrativa aos projetos especiais
ligados às escolas e criam a possibilidade real de alternativa para a educação do
trabalhador. (SME, 1992, p.2)

Os problemas e soluções apontados nas e pelas escolas convergiam, então, para o desenho de uma nova proposta para EJA na cidade: o CEMES.

Muito embora tenham sido idealizados em 1992, os CEMES foram criados na cidade de São Paulo somente na gestão posterior, do prefeito Paulo Maluf (PDS), através do Decreto 33.894, de 16 de dezembro de 1993, passando o primeiro deles a funcionar apenas em 1994 em local diferente do estabelecido originalmente. ${ }^{23}$

No final da administração petista na cidade, o cenário da educação de jovens e adultos apresentava, contudo, uma significativa modificação com as três frentes que mencionamos anteriormente.

\footnotetext{
${ }^{22}$ Mario Sergio Cortella (1954), filósofo, escritor e professor paranaense. mestre e doutor em Educação pela PUCSP com a Orientação de Moacir Gadotti e Paulo Freire, produz vários estudos que tangenciam o paradigma da Educação Popular.

${ }^{23}$ A proposta de criação e instalação do primeiro CEMES previa que se localizasse no Tendal da Lapa e, posteriormente, no Centro de Educação do Jardim Miriam. Justificando-se a inadequação dos prédios, transferiuse o primeiro CEMES para a Administração Regional de Ermelino Matarazzo. (SME, 1996, p.1)
} 
Parte das iniciativas de alfabetização de jovens e adultos junto à sociedade civil, pouco estruturadas e sem recursos, foram mobilizadas e agregadas ao MOVA; buscava-se a integração entre escolarização e trabalho na Frente do Funcionalismo e empreendiam-se mudanças estruturais, organizacionais e pedagógicas nas escolas.

Diminuiu a porcentagem de escolas municipais ociosas no período noturno de $58,25 \%$ em 1989 para 6,12\% em 1992, e aumentou o número de matrículas. Frente aos 12.821 matriculados nas EMES em 1988, extintas no ano de 1989, chegava-se a 28.514 matrículas na modalidade Suplência I e 50.218 na Suplência II nas Escolas Municipais de Primeiro Grau no final de 1992.

Tabela 4 - Evolução de Matrículas na EJA entre 1989 e 1992

\begin{tabular}{ccccccc}
\hline \multicolumn{7}{c}{ Número de Matrículas na EJA de 1988 a 1992 } \\
\hline Modalidade & $\begin{array}{c}\text { Tipo de } \\
\text { escola }\end{array}$ & $\mathbf{1 9 8 8}$ & $\mathbf{1 9 8 9}$ & $\mathbf{1 9 9 0}$ & $\mathbf{1 9 9 1}$ & $\mathbf{1 9 9 2}$ \\
\hline & EMPG & - & - & 20150 & 27745 & 28514 \\
Suplência I & Entidade & - & - & 8876 & 10196 & 14977 \\
& EMPG & 5492 & 28980 & 28222 & 34613 & 50218 \\
& EMES & 12821 & - & - & - & - \\
Suplência II & Entidade & - & - & - & 120 & 1240 \\
Total & & 18313 & 28980 & 57248 & 72674 & 94949 \\
\hline
\end{tabular}

Legenda: EMPG - Escolas Municipais de Primeiro e Segundo Grau

EMES: Escolas Municipais de Ensino Supletivo

Entidade: Classes que funcionam fora da escola

Tabela adaptada de: SME-APT, 1992 Mês Base: Março

Na tabela anterior, é importante notar a contabilização das matrículas de Suplência 1 a partir de 1990, após o Programa EDA, da SEBES, ter sido absorvido pela SME em 1989. Desde então, nota-se um crescimento significativo do número de matrículas nessa etapa de ensino. Outro dado importante é a extinção das Escolas Municipais de Ensino Supletivo (EMES), que no ano de 1988 contavam com 12.821 matriculados na Suplência II. (SME, 1992, p. 28). Elas foram incorporadas às $\mathrm{EMPSG}^{24}$, visando integrar as ações de SME.

Ainda havia grandes desafios para essa modalidade de ensino: apenas um terço das escolas aderiu ao Movimento de Reorientação do Ensino Noturno; grande parte dos projetos implantados era pontual e não abarcavam todas as turmas, professores ou modalidades; existia uma pluralidade de propostas entre as escolas que apresentavam dificuldades em se integrarem

\footnotetext{
${ }^{24}$ Nomenclatura à época das Escolas Municipais de Ensino Fundamental (EMEFs).
} 
em alternativas pedagógicas mais abrangentes e multidimensionais (SME, 1992, p. 43).

De fato, construir um novo modelo de ensino para jovens e adultos trabalhadores com a participação das escolas não era tarefa fácil, exigia diálogo constante com os NAEs e aumento de sua equipe e recursos para conseguir maior adesão das soluções propostas por SME nas escolas.

Muito embora procurasse redimensionar aspectos organizacionais, estruturais e pedagógicos nas unidades educacionais, os próprios NAEs também possuíam problemas relacionados ao número insuficiente de pessoal, qualificação profissional e de infraestrutura, que dificultavam sua aproximação das unidades de ensino para acompanhar, integrar as experiências e viabilizar sua continuidade. As ações para EJA, no entanto, lograram experiências que redesenhavam o ensino na rede.

\subsection{Gestão de Paulo Maluf (PP) e de Celso Pitta (PP) - de 1993 a 2000}

Eleito Paulo Maluf como prefeito de São Paulo, do então Partido Progressista Brasileiro (PP), seu programa de governo conferia novos contornos também às políticas públicas de educação na cidade. Paulo Maluf tinha como base eleitoral os setores conservadores do município, tendo sido indicado para diversos cargos públicos durante o período de ditadura militar (1964 -1985) e nomeado, inclusive, Governador Estadual de São Paulo (1979 - 1982). A gestão de Paulo Maluf privilegiaria a construção de grandes obras públicas e restringiria os espaços participativos como os conselhos, limitando sua função à consulta sobre aquelas políticas implementadas e negando-lhes o protagonismo para propor ou deliberar ações (COUTINHO, 1997, p.129).

Envolta no discurso da "Qualidade Total", que permeou as políticas de todas as secretarias municipais, as políticas educacionais seguiram a lógica da administração empresarial. A premissa da "Qualidade Total" embasava-se no pensamento de Edwards Deming e ficou conhecida com o modelo japonês de administração dos negócios no pósguerra (FUNARI, 2008, p. 39). Edwards Deming propunha que a qualidade total das organizações pudesse ser alcançada através do controle estatístico dos processos de 
desenvolvimento de determinado produto ou serviço. A partir da constatação de que esses processos são amplamente variados e devem obedecer às condições do mercado competitivo e necessidades dos clientes, Deming postula 14 princípios $^{25}$ que poderiam ser adotados por qualquer organização para obter maior eficiência, ou seja, diminuição de custos e melhoria dos resultados.

Transposta para as instituições públicas de ensino, a teoria da qualidade total privilegiaria a adoção de alguns dos princípios postulados por Deming no tocante ao controle dos processos, qualificação profissional, formação como meio para o indivíduo desempenhar determinado papel, entre outros.

Art. $1^{\circ}$ - Fica instituído o "Programa Gestão da Qualidade Total na Administração Pública Direta e Indireta no Município de São Paulo", com os seguintes objetivos: I Elevação da produtividade na execução dos serviços prestados à população; II Redução de custos; III - Elevação do nível de satisfação dos usuários e beneficiários dos serviços públicos prestados; IV - Instituição de mecanismos propícios à geração de idéias e soluções criativas e inovadoras, através da participação ativa de todos os servidores e empregados e, se for o caso, da comunidade atendida; V - Instalação de estruturas voltadas à melhoria contínua da qualidade das atividades e serviços realizados pela Administração do Município de São Paulo. . $4^{\circ}$ - No desenvolvimento do Programa Gestão da Qualidade Total, as Secretarias, órgãos e entidades por ele abrangidos deverão estabelecer mecanismos para a valorização e participação os servidores e empregados, motivando-os para uma ativa contribuição à melhoria contínua da qualidade dos serviços prestados. (PMSP, Decreto $\left.\mathrm{N}^{\circ} 35.134 / 995\right)$

A administração de Paulo Maluf propunha, então, um novo sentido de qualidade do ensino. Concebendo a educação como produto ou serviço prestado, a alternativa para atingir a qualidade da prestação dos serviços baseava-se na ação comprometida do funcionalismo público, sua sensibilização e capacitação para satisfação da "clientela" (como os cidadãos, sujeitos dos direitos, passaram a ser vistos).

O documento "Encontros", que reunia textos e planos de formação dos professores de EJA, procurava difundir esses pressupostos. O primeiro artigo no documento "Participação, valores e essência" conferia novo sentido às práticas participativas e à formação dos profissionais da educação.

\footnotetext{
${ }^{25}$ São eles: criar constância de propósitos (definir a "missão" das organizações); adotar a nova filosofia (cada indivíduo da organização deve responsabilizar-se pelo cumprimento da missão); acabar com a dependência da inspeção em massa (priorizar a qualidade desde o primeiro estágio de desenvolvimento do produto); minimizar o custo total; melhorar o sistema (aumentar a eficiência, diminuir gastos e otimizar produtos); instituir a formação (a partir da formação cada funcionário poderia desempenhar sua função de maneira adequada à missão da organização e atendimento das necessidades dos clientes); adotar e instituir lideranças; acabar com o medo (permitir que os funcionários expressem as dificuldades a fim de superá-las); eliminar slogans, exortações e metas; eliminar quotas de trabalho, promover orgulho pelo trabalho; auto-melhoria, não basta ter pessoal competente, é necessário que ele busque contínuo aperfeiçoamento (SARAIVA, 2009).
} 
Os que não veem alternativas a não ser esperar por respostas dos “canais competentes" transformam a questão educacional em um imenso círculo vicioso, projetando um futuro sombrio. (...) Não seria através de uma participação desinteressada, generosa, desprendida, com o único objetivo de ajudar o semelhante, transcendendo a busca de qualquer outro tipo de recompensa, admiração, glória pessoal, a forma mais legítima de dar real significado às nossas vidas? A democracia participativa tem, como sustentáculo, valores. Solidariedade, respeito humano, humildade, alta consideração pelo outro são valores a resgatar nesse processo de criação conjunta de um mundo melhor para todos. Na medida em que conseguirmos enxergar um pouco de nós mesmos em cada um de nossos semelhantes, estaremos criando soluções o tempo todo, contribuindo para a criação de uma grande sociedade que toma conta de si mesma. $\mathrm{O}$ resgate dos valores essenciais em nossa sociedade tem tudo a ver com cada um de nós. Ele começa dentro de cada indivíduo em primeiro lugar. A partir daí, o processo evolui de forma natural, sem grande esforço, gerando transformações em cadeia de proporções muitas vezes inimagináveis. (AMANA, 1992, p. 22 apud DOT, 1994, p. 6)

Relevado o excesso de generalizações do texto, observa-se que embora se refira à coletividade, as ações para "melhoria do mundo para todos" seriam submetidas ao grau de altruísmo ou mobilização do indivíduo. Cada pessoa de uma organização era responsável pelas transformações em proporções inimagináveis, a partir documento em que possuísse valores, ou os desenvolvesse. As mudanças no cenário educacional seriam promovidas através de maior comprometimento de cada um e não por ação direta dos "canais competentes".

A participação seria limitada à ação ou intenção individualizada, deixando de implicar o movimento coletivo. Dessa forma, problemas multidimensionais - traduzidos como desafios estruturais, organizacionais e pedagógicos no governo de Erundina (1989-1992) - seriam tratados a partir da gestão do trabalho individual. As DREMs seriam guiadas pelos seguintes princípios:

- igualdade, liberdade, solidariedade, dignidade e justiça social, expressos na Lei de Diretrizes e Bases da Educação Nacional;

- Valorização da educação e do educador, atendimento à demanda, escola voltada para o aluno, plena utilização dos recursos e normatização administrativa, eixos da Política educacional;

- formação do homem integral, cujas diferentes dimensões devem ser respeitadas, valorizadas e desenvolvidas;

- filosofia da Qualidade Total, adotada como pressuposto do trabalho a ser desenvolvido;

-Liberdade de aprender, ensinar, pesquisar e divulgar o pensamento a arte e o saber, respeitando o pluralismo de ideias e de concepções pedagógicas preceituadas pela Constituição Federal;

- planejamento da ação educativa consubstanciado nos princípios de coordenação, participação, integração e permanência;

- respeito a vivência e à construção da Qualidade Total pela Escola. (SME-DOT, 1994, p.1) grifos nossos.

Esses princípios buscavam amparo em dispositivos legais para inserir a filosofia da qualidade total nas ações educacionais na cidade. Embora incluíssem nos discursos o respeito 
à vivência e a participação das escolas, o pluralismo de ideias e liberdade, eles estariam submetidos à plena utilização de recursos e à normatização administrativa.

Sob o mesmo pressuposto propagado no governo anterior, de desenvolvimento do trabalho educativo a partir da realidade local, assentava-se outro projeto de rede. Ele não implicava a noção colaborativa, mas passava a concentrar esforços no cumprimento de metas pelas unidades escolares.

Embora a proposta da Qualidade Total não tenha se firmado na rede ao longo da gestão Maluf, a EJA a incorporaria na busca pelo atendimento individualizado dos educandos. Verifica-se o aumento de cursos de instrução dirigida e das modalidades semipresenciais voltadas também à qualificação profissional.

A EJA também seria marcada pela desmobilização de coletivos que buscavam espaços de participação. Destaca-se a extinção abrupta do MOVA, alegando-se irregularidades na realização de parcerias com as entidades sociais. Em seu lugar, houve o redimensionamento de duas frentes educativas presentes na gestão anterior: para a Suplência ${ }^{26}$ I, criou-se o Programa de Alfabetização de Adultos (ProAlfa) e, para a Suplência II, os Centros Municipais de Ensino Supletivo (CEMES); ambos foram instituídos pelo Decreto n. 33.894, de 16 de dezembro de 1993.

O ProAlfa oferecia curso de Suplência I para jovens e adultos a partir dos 14 anos em dois módulos, sendo o primeiro correspondente às duas séries iniciais e o segundo módulo correspondente às séries finais do Ensino Regular. Com duração de 720 horas cada, as atividades na sala de aula eram de quatro horas-aulas de segunda a quinta e duas horas-aulas na sexta-feira. Os objetivos do curso eram:

- Ampliar a possibilidade de aceso ao Ensino Fundamental àqueles que não tiveram
oportunidade na idade própria.
- Desenvolver alfabetização e demais termos da Suplência I, através de Convênios
com Entidades da Sociedade Civil.
- Assegurar aos Jovens e Adultos conteúdos mínimos de aprendizagem que atendam
necessidades elementares da vida contemporânea.
- Oferecer formas diversificadas de atendimento que se ajustem às características e a
disponibilidade de adolescentes e adultos que estão engajados na força de trabalho
(SME, 1994, p.22-23)

O trabalho era realizado em pequenos grupos, de acordo com o nível de conhecimento e ritmo de aprendizagem de cada estudante. Os educandos recebiam fascículos chamados de

\footnotetext{
${ }^{26}$ Usamos o termo Suplência para tratar do PROALFA e CEMES, buscando reproduzir a terminologia utilizada pela Secretaria Municipal de Educação nos documentos em que se apresentam essas iniciativas.
} 
"Unidades de Estudos", programadas para serem estudadas individualmente. Após o término de cada unidade, o estudante poderia passar à seguinte até concluir todas aquelas referentes ao módulo frequentado. Portanto, a duração do curso era variável de acordo com o desempenho individual.

Os cursos podiam ser desenvolvidos em classes fora das unidades escolares, em espaços cedidos por empresas ou entidades conveniadas à SME. As escolas que manifestavam interesse também poderiam realizá-lo. Os professores eram do quadro de pessoal da Rede ou contratados pelas empresas e entidades (SME, 1994). Os 13 CEMES, implementados durante a gestão de Paulo Maluf, funcionavam vinculados às DREs e tiveram seu projeto original redesenhado:

O Plano de Curso apresentado pela anterior administração e aprovado pelo Parecer CEE 1344 de 18 de dezembro de 1992 está sendo substituído pelo presente, tendo em vista as dificuldades em operacionalizá-lo e a adequação às diretrizes da Política Educacional da atual administração. (SME, 1996, p.1)

No novo Plano de Curso, os CEMES adotaram a metodologia de instrução programada e passaram a se organizar no sistema de módulos e créditos. Os Centros contavam com equipe pedagógica própria da rede municipal e funcionavam em prédios da prefeitura adaptados, espaços cedidos ou alugados. Funcionavam no período diurno e noturno, buscando como objetivos:

- desenvolver a formação de uma consciência social, crítica, responsável, solidária
e democrática, onde o educando vá, gradativamente, percebendo-se agente de sua
própria educação e de transformação da sociedade.
- oferecer o ensino fundamental, na modalidade supletiva, cuja metodologia concilie
qualidade e flexibilidade, propiciando condições para que o aluno adquira
autonomia na busca do conhecimento.
- propiciar um processo de escolarização que respeite a identidade cultural do aluno e
contribua para a reorganização do conhecimento construído ao longo de sua vida
(SME, 1996, p. 2).

Notamos que entre os objetivos dos CEMES permanecem alguns termos recorrentemente utilizados na gestão Erundina (1989-1993) e que constavam no projeto original dos CEMES. No entanto, os sentidos da "consciência social e crítica", "flexibilidade", "qualidade", bem como os demais termos negritados no excerto acima, apontavam projetos políticos distintos para a modalidade. A flexibilidade de horários coincidia com a individualização dos estudos; os educandos seriam os próprios responsáveis por sua formação; os professores eram os técnicos que tirariam dúvidas e avaliariam sua aprendizagem; os Centros, locais de transmissão e teste de conhecimentos. 
Segundo Ribeiro:

Em algumas propostas de grande penetração, a flexibilidade é traduzida na individualização do ensino, principalmente por meio de modalidades de atendimento não presenciais. Nesses casos, a tendência é diminuir a importância do papel do educador na regulação dos processos de aprendizagem dos alunos, os quais supostamente estariam aptos a controlar seus próprios tempos e procedimentos de estudo, tendo como referência principal os materiais instrucionais. (RIBEIRO, 1999, p. 196)

De fato, nos CEMES os estudantes podiam frequentar a Suplência I e II. A presença nas aulas era facultativa aos estudantes e programadas para tirarem dúvidas em atendimentos individualizados com hora agendada.

Os alunos matriculavam-se nas disciplinas e as cursavam também através do estudo individual das Unidades de Estudo, cadernos didáticos formulados pela Universidade Estadual Paulista Júlio de Mesquita Filho (UNESP), sob coordenação geral do Prof. Dr. Romualdo Dias, financiado com recursos do Fundo Nacional de Desenvolvimento da Educação (FNDE).

Todas as disciplinas contavam com um mesmo modelo de material didático, que deveria dirigir o estudo individual dos estudantes, como exemplificado na Figura 1.
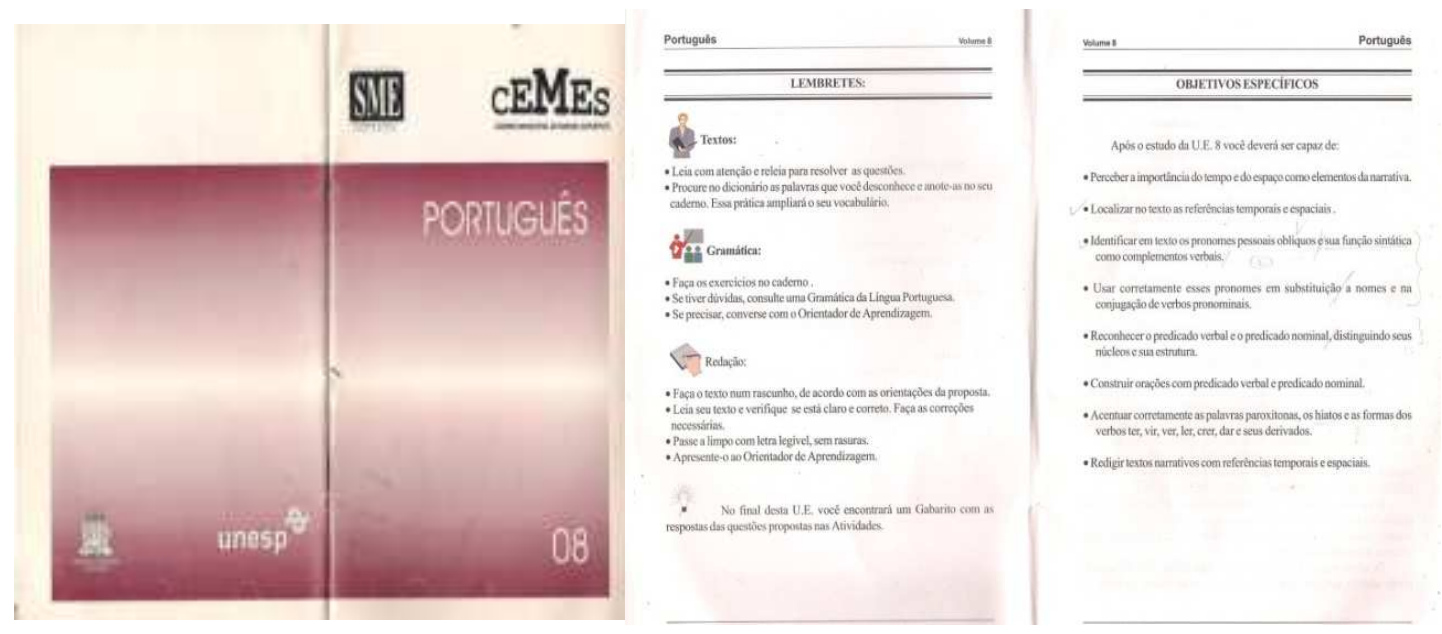

Figura 1 - Unidade de Estudos de Português ${ }^{27}$

Além disso, muitos educandos não possuíam níveis de letramento suficientes para o estudo individual. A fala das entrevistadas Êda Luiz, Coordenadora Geral do CIEJA Campo Limpo, antigo CEMES da região, ilumina os conflitos dessa proposta de ensino.

Eram125 apostilas, divididas por disciplinas, era eliminação de disciplina. (...) E aí nós começamos, fizemos muitas discussões, sobre como fazer as avaliações, de acordo com a série, para não ser só a prova, mas que os alunos pudessem aprender algo com ela também. A gente falava assim: Meu Deus do céu, eu estudei tanto, ouvi

\footnotetext{
${ }^{27}$ Imagem ampliada disponível no Anexo.
} 
tanto, eu não sei o que estou reproduzindo aqui. É memorização? Nós tivemos um caminhoneiro, e o caminhão ficou parado 20 dias quebrado, ele chegava às 08:00 da manhã, estudava, estudava, conseguia eliminar a apostila. Assim, em 20 dias ele tirou o certificado da $8^{a}$ Série, fez as 125 apostilas. Mas aí que nós conseguimos perceber, a pessoa tem boa memória, ela memorizava, a questão estava lá.(...)Tinham pessoas que diziam ter dificuldade, porque o sistema reforçava "Eu sou burro mesmo, não aprendo, não consigo". "Ah, olha, eu li essa apostila duzentas vezes e eu não entendi nada, então eu não tenho compreensão da escola”. Reforçava, né, essa coisa que ele já trazia com ele de que não era capaz, que não acrescentava nada na vida dele aquela coisa. Esse era o " $x$ " da questão. E aí começamos mudar as avaliações; assim, colocar na avaliação, um modo de aprender, um problema..." (Êda Luiz, dezembro de 2012)

Indicavam-se, entre as orientações pedagógicas, as especificidades da educação de jovens e adultos e a necessária adaptação curricular. Na prática, as Unidades de Estudos orientavam-se pelo currículo do ensino regular, fragmentando as áreas de conhecimento em disciplinas e essas em unidades. Privilegiava-se a transmissão dos conteúdos, como revela a menção da educadora entrevistada aos processos de "memorização".

Também chama a atenção o efeito da metodologia adotada naqueles que já tinham se afastado da escola por dificuldades de aprendizagem a partir de propostas distantes de sua linguagem e vivência cotidiana. Nesse sentido, o depoimento de Êda Luiz corrobora a análise de Ribeiro (1999):

Estudo sobre as condições de alfabetismo de jovens e adultos paulistanos (Ribeiro 1999) sugere que a capacidade de auto-regulação para tarefas que envolvem leitura de textos para busca de formação e instrução exige um grau considerável de experiência com a cultura letrada e escolar, experiência essa que majoritariamente corresponde à do pessoal com pelo menos o Ensino Médio completo. Assim, as modalidades de ensino a distância que não provêm o suporte regulador do educador e de um grupo de colegas não parece ser o mais adequado para o ensino fundamental, ao menos para a grande maioria dos que necessitam essa modalidade educativa, constituída de pessoas que foram alijadas não só da escola, mas também dos espaços sociais em que predomina a cultura escrita. Além disso, é uma constatação muito frequente, em diversos estudos sobre a educação de adultos, que as aprendizagens mais valorizadas pelos educandos que concluem seus estudos encontram-se no terreno das atitudes. Sabendo que os conteúdos atitudinais dependem de as sociais carregadas de afetividade, é inevitável ponderar também os limites de propostas de ensino que não promovem interações sociais (Sarabía 1992). (RIBEIRO, 1999, p. 196)

Os CEMES tinham as mesmas características dos Centros de Estudos Supletivos (CES). Os CES, de acordo com estado da arte sobre EJA de Haddad (2002), são apontados em estudos como propostas inadequadas às necessidades educativas de jovens e adultos, uma vez que os cursos modelados segundo a instrução dirigida negligenciam os tempos e processos de aprendizagem dos educandos, a importância da coletividade e vinculação do estudante com o 
espaço escolar.

Torres (1997) conclui que os CES se configuram como uma proposta mediadora diante da extinção dos movimentos educativos e culturais reprimidos pelo regime autoritário. A proposta dos CES supervalorizou o aspecto individual, sendo negligenciados aspectos como capacitação de professores, material didático adequado e legislação específica. $\mathrm{O}$ aluno não está situado dentro do contexto escolar. O ilimitado tempo fixado nos CES representa um descompromisso da instituição com o aluno, sendo necessária uma frequência mínima que descaracterize a fluidez de que se revestem os Centros. (HADDAD, 2002, p.93)

Nesse período, os CEMES foram implantados, tendo em vista a confluência de problemas semelhantes àqueles percebidos na gestão anterior, no entanto, o fluxo das soluções e da política, são distintivos e sua reconfiguração desvirtua a proposta original.

Na gestão de Paulo Maluf, observamos, ainda, investimentos no Teleducar e a criação do Centro Municipal de Capacitação e Treinamento (CMTC), aprovados pelo parecer CEE 501/1995. Os CMTCs foram idealizados para qualificação profissional de jovens e adultos.

Instituído pelo Decreto no 35.456 de 30 de agosto de 1995, os cursos do Teleducar funcionariam em parceria com a Federação das Indústrias do Estado de São Paulo (FIESP), Centro das Indústrias do Estado de São Paulo (CIESP), o Serviço Social da Indústria (SESI) e o Serviço Nacional da Aprendizagem Industrial (SENAI).

Eles podiam ser implementados em escolas, empresas ou entidades conveniadas, disponibilizando-se as salas de aulas equipadas de TV e vídeo em que para transmitir os filmes do Telecurso da Fundação Roberto Marinho (SME, 1998, p. 4) e também se destinavam à qualificação profissional, tendo se restringido a iniciativas isoladas.

Indicado por Paulo Maluf, Celso Pitta $^{28}$ (PP) foi eleito prefeito da cidade em 1996, vencendo em segundo turno a ex-prefeita Luíza Erundina do PT. Na sua gestão, verificamos a permanência das propostas educativas da gestão de Paulo Maluf, promovendo os cursos semipresenciais e com baixo investimento nas EMEFs para a modalidade.

O impacto negativo FUNDEF no número de matrículas de EJA, devido à desvinculação de recursos para essa modalidade, pode explicar também a priorização dos cursos semipresenciais, em tese, mais baratos.

\footnotetext{
${ }^{28}$ O ex-prefeito Celso Pitta foi denunciado por corrupção, chegando a ter seu mandato como prefeito cassado em 1998, devido ao "Escândalo dos precatórios", em que foram desviados milhões de reais quando era Secretário das Finanças na sua gestão de seu antecessor, Paulo Maluf.
} 


\subsection{A gestão de Marta Suplicy (PT) e a idealização do CIEJA (2001-2004)}

Após o conturbado período da gestão de Celso Pitta na prefeitura de São Paulo (19972000), Marta Suplicy (PT) foi eleita em 2000. Sua candidatura anunciava o "governo da reconstrução", respondendo à indignação da população com os escândalos de corrupção nas duas gestões precedentes e ao descontentamento com a restrição dos espaços participativos na cidade.

Observa-se em sua administração uma clara referência à gestão anterior do PT - de Luíza Erundina (1989-1992). A nova gestão do PT na cidade também buscaria dialogar com as comunidades escolares na definição das políticas educacionais.

A exemplo de Freire, que se dirigiu aos educadores da rede municipal através de uma carta intitulada Aos que fazem a Educação conosco em São Paulo, quando assumiu a SME em 1989, o Secretário da Educação Dr. Fernando José de Almeida também lhes direcionou uma carta no documento Retomando a Conversa: construção da política educacional da Secretaria Municipal de Educação (SME-DOT, 2001, p. 3).

Não apenas o termo "retomando a conversa" apontava a pretensão de dar continuidade aos trabalhos desenvolvidos na gestão de Luíza Erundina (1989-1992), recuperava-se também a maioria de suas prioridades: "democratização do acesso e permanência”, "democratização da gestão" e "democratização do conhecimento - qualidade social da educação", com exceção da Alfabetização de Jovens e Adultos. Esse fator denota que a EJA ainda ocuparia lugar secundário entre as prioridades do governo.

A “democratização do conhecimento - qualidade social da educação” desdobrava-se em duas estratégias: Reorientação Curricular e Formação Permanente do Educador. Contrapondo-se à qualidade total, do governo Maluf (1993-1996), o adjetivo "social" indicava uma concepção de qualidade da educação que buscaria, segundo os discursos, desenvolver ações intersecretariais e proclamavam uma proposta emancipadora.

\footnotetext{
Defendemos uma ação educativa vinculada a um projeto de sociedade comprometido com a emancipação dos explorados de nossa cidade. Ação que assimila e supera os princípios e conceitos da escola. No processo de construção deste Projeto, a participação de todos os envolvidos é fundamental. Isto quer dizer que também é fundamental o respeito às decisões coletivas alicerçadas nas diretrizes da política educacional de SME, significando a possibilidade de que a identidade do aluno, as características e necessidades da comunidade permeiem o projeto político-pedagógico da escola, dando-lhe sentido e vida. (SME-DOT, 2002, p. 19)
} 
É nesse sentido, que se empreendeu a construção dos Centros Educacionais Unificados (CEUs), que buscavam integrar diferentes setores num projeto pedagógico pela inclusão e melhoria da qualidade de vida das comunidades em que se inseriam. Para constituir a Cidade Educadora $^{29}$, os CEUs articulariam as unidades educacionais de seu entorno, que contribuiriam para a proposição e desenvolvimento de ações esportivas, culturais e educacionais. (PACHECO, 2009)

A proposta de Democratização da Gestão buscaria, então, retomar a participação da comunidade escolar na reflexão sobre o currículo, na elaboração de projetos e na avaliação de suas ações. Visaria também o fortalecimento dos Conselhos de Escola e a rearticulação dos Conselhos Regionais dos Conselhos de Escola (CRECEs).

$\mathrm{Na}$ educação de jovens e adultos, a nova concepção de qualidade da educação seria pautada pelo Movimento de Reorientação Curricular da EJA.

(...) construir um currículo ou currículos emancipatórios para EJA implica, entre outros aspectos, possibilitar a compreensão, o reconhecimento e a consideração dos educandos e dos educadores nos processos vividos. Implica também em incorporar as diferenças como identidade desses sujeitos e buscar o desenvolvimento de práticas que favoreçam a construção do conhecimento, estimulando a autonomia dos educandos, na perspectiva da vivência da cidadania ativa. (POSSANI, 2008, p. 51)

Para Possani (2008), os princípios de autonomia e participação no Movimento de Reorientação Curricular para EJA estariam relacionados às unidades educacionais em um nível,e em outro ao sistema educacional. Nas escolas, refletiam-se na consideração da diversidade dos educandos para configuração de um currículo emancipador. Elas deveriam desenhar propostas a serem experimentadas, avaliadas e refeitas continuamente. Nas políticas, os princípios refletiam em mudanças de diretrizes necessárias para que os sujeitos tivessem o direito à educação com qualidade garantido. Essas diferentes nuances, no entanto, eram marcadas por um descompasso entre os discursos e as práticas das escolas e de SME.

(...) havia uma dificuldade de entendimento e até de resistência dos educadores e uma insegurança por parte da SME. A resistência das escolas se fundamentava na desconfiança em relação aos limites desta autonomia e da própria dificuldade de gerir o processo de construção e assumir os riscos desta experiência de autonomia curricular e, por parte da SME, a insegurança talvez se desse por conta do controle desses currículos. (POSSANI, 2008, p. 46)

\footnotetext{
${ }^{29}$ O movimento internacional das Cidades Educadoras dialoga com o conceito de Escola Cidadã, baseado no pensamento de Paulo Freire. Emergente no início dos anos 1990, o movimento pauta-se na possibilidade de que a escola seja palco de reflexão sobre a cidade, ao mesmo tempo em que a cidade possua um projeto intencional e educativo para os cidadãos, considerando as diversificadas aprendizagens culturais, sociais e políticas que nela se vivencia (GADOTTI, 2003).
} 
Apesar das dificuldades, também devido a elas, seria reestruturado o diálogo com as unidades de ensino através de um novo desenho entre os NAEs, DOT e escolas, de maneira a se orientar os níveis de participação das comunidades escolares de acordo com a política educacional e evitar a fragmentação das ações.

(...) outra iniciativa importante no nível central foi a reestruturação organizacional da Diretoria de Orientação Técnica (DOT) fundamentada na crítica a uma visão fragmentada do Sistema Educacional, à ausência de uma compreensão articulada dos segmentos envolvidos no processo educativo e ao isolamento das escolas (SME-DOT, 2001, p. 5).

Foram criados os Grupos de Formação Permanente (GAAEs), cujo objetivo era promover um espaço de diálogo, estudo e reflexão entre Supervisores Escolares, Diretores, Coordenadores, Professores, Assistentes Técnicos Educacionais e Grupos de Trabalho da DOT. Os GAAEs cumpririam também a função de difundir e promover maior adesão às soluções educacionais propostas por SME.

A frente do funcionalismo foi parcialmente retomada, em que destacamos o Programa Especial de Formação docente ${ }^{30}$ em curso normal em nível médio, promovido pela Secretaria Municipal de Educação de São Paulo para auxiliares de desenvolvimento infantil (ADIs) que atuavam na rede direta de centros de educação infantil e não tinham habilitação para o magistério. (OLIVEIRA et. al., 2004)

Verificamos que dentro de outro contorno das políticas educacionais na cidade, a ascensão da EJA à agenda de prioridades resultaria da confluência do "fluxo de política", "fluxo dos problemas" e "fluxo de soluções" (KINGDON, 2003), que influenciou a idealização e implantação dos CIEJAs nessa gestão.

No fluxo de política, a transição de governo rompia com as decisões políticas anteriores e recuperava as concepções e programas da gestão do Partido dos Trabalhadores entre 1989 e 1992. O objetivo da política educacional "democratização do acesso e permanência" se relacionaria com as discussões sobre a LDB 9394/96, que consolidava a EJA enquanto direito, devendo ser oferecida de acordo com as especificidades dos alunos.

Nesse período, as deliberações da CONFINTEA 1997 ratificavam a importância da EJA nos países emergentes, segundo a perspectiva da educação ao longo da vida. Além disso, o Parecer do Conselho Nacional de Educação 11/2000 (CNE 11/2000), do Relator Jamil Cury,

\footnotetext{
${ }^{30}$ O Programa atendia cerca de 3600 auxiliares de desenvolvimento infantil (ADIs).
} 
estabelecia Diretrizes Curriculares Nacionais para a Educação de Jovens e Adultos, definindo as funções reparadora, equalizadora e qualificadora dessa modalidade de ensino.

Entretanto, o governo de Fernando Henrique Cardoso (FHC), através da Emenda Constitucional 14/96, desobrigou o Estado de aplicar metade dos recursos vinculados à educação no cumprimento das disposições transitórias da Constituição Federal de 1988 para erradicação do analfabetismo no período de dez anos. O veto do ex-presidente Fernando Henrique Cardoso, em 1996, ao cômputo de matrículas de educação de jovens e adultos para obtenção de recursos pelos estados e municípios via FUNDEF também impactou na diminuição da oferta da EJA em diferentes cidades. Concorrentemente, o governo estadual paulista se retirou da oferta do primeiro segmento do Ensino Fundamental para jovens e adultos, delegando tal responsabilidade aos municípios, conforme o Decreto 40.673 (VIEIRA, 2011).

Assim, o "clima" nacional (national mood) e estadual desfavorecia a ascensão da EJA à agenda "decisional". Nos governos de oposição, porém, buscava-se ratificar a EJA enquanto direito, contrariando as políticas que desfavoreciam seu financiamento e a promoção do acesso e permanência dos jovens, adultos e idosos às escolas no cenário nacional.

A crise entre os governos anteriores e as organizações populares que atuavam junto ao MOVA, extinto na administração de Paulo Maluf, davam relevo à questão da alfabetização de jovens e adultos. Os grupos pressionavam a administração petista para retomar as parcerias e posicionar-se contra os mecanismos de marginalização da EJA. De fato, observamos a reestruturação do MOVA a partir da retomada e ampliação dos convênios com diversas organizações sociais. Abbonízio (2007) aponta que a exigência da situação jurídica legalizada para assinatura do convênio com as ONGs, em detrimento da sua aprovação pelo fórum do MOVA, estabelecera novos vínculos de trabalho entre elas e a SME. No lugar da coerência entre a visão e o compromisso político da alfabetização dos jovens e adultos propiciada pela realização dos fóruns MOVA na gestão de Erundina, verificou-se menos articulação entre as ONGs atuantes no movimento. No entanto essa institucionalização do MOVA no município favoreceria sua continuidade nas demais gestões.

Lembramos que a extinção do MOVA no governo Maluf coincidiu com a instalação do ProAlfa e dos CEMES na rede, o que reforçava a percepção negativa sobre eles, que teriam sido "desvirtuados" do projeto original da gestão de Erundina (1992). A fala da entrevistada 
Marisa Darezzo, diretora de DOT-EJA na gestão de Marta Suplicy, deixa transparecer essa percepção, que influenciaria a reformulação do projeto dos CEMES.

Tínhamos o MOVA, que tinha sido criado na gestão da Erundina também, acabaram com o MOVA. Acabaram com o MOVA e foram suprimindo salas, e surgiu uma outra modalidade aí que eles chamavam de CEMES - Centros Municipais de Educação de Adultos, de Ensino Supletivo.(...) Na gestão Erundina tinha essa ideia desses Centros, que seriam para funcionar e atender a uma demanda que às vezes não é contemplada no Ensino Noturno, que são aquelas senhoras, são as pessoas que trabalham em turnos diversos, então teriam a disponibilidade de tentar estudar durante o dia; seria uma alternativa para esses alunos, para essa demanda que fica solta por aí, não tem aonde eles possam recorrer. Então, a ideia tinha um viés, mas depois ela foi implantada como uma oferta no noturno. Então, eram esses plantões, os professores eram contratados e ficavam na sala de aula esperando pelo aluno. (Marisa Darezzo, dezembro de 2012)

A ideia de que os CEMES tinham se desviado do projeto original da gestão petista estava presente, então, entre os próprios técnicos de DOT-EJA. Ela seria reforçada tanto pelas organizações populares que atuavam com o MOVA, quanto pelos profissionais do magistério da rede municipal. Esses atores demandavam o fim daquele modelo.

O relato da Professora Célia Borges, que trabalhava no CEMES da região do Butantã, revela que além da percepção negativa que associava a instalação dos Centros à extinção do MOVA, havia uma visão crítica sobre a condição de trabalho diferenciada dos professores e gestores CEMES, considerada privilegiada por muitos quando comparada à jornada dos demais docentes da rede. A organização da carga horária dos professores era dividida entre os tempos de atendimento aos estudantes (seja de orientação de estudos nos plantões, seja aplicação de provas) e tempo de discussão, estudo e elaboração das avaliações.

E aí quando houve a mudança da gestão, que veio para o governo da Marta, se tentou, eu acredito, retomar um pouco o que era o projeto original; mas, também, o CEMES era mal visto, se falava muito que era cabide de emprego. O nosso, aqui, do Butantã, nunca foi... Então, eu acho que também essa foi uma das maiores motivações. Assim, chegaram e foram avaliar o projeto. (...) Eu acho que a ideia de cabide de emprego que eu tenho é de alguém que está pendurado sem fazer nada; mas no CEMES sempre fizeram, sempre se deu aula e atendeu aluno. Só que tinha uma coisa assim, do tipo: o porquê que a pessoa estava lá, aquela pessoa e não outra. No nosso caso, a gente passava por um processo seletivo, a gente tinha que apresentar um projeto, depois passava por entrevista. As pessoas não vinham para cá porque conheciam alguém; havia, internamente uma avaliação. (...) Eu me lembro que havia muito, assim, aquele "zum-zum-zum”, aquela conversa: "Ah, o Maluf inventou um projeto para acabar com a EJA nas escolas.” Não é? Tinha um pouco esse lado de um certo terrorismo de que a gente estava fazendo alguma coisa para não ter EJA... E também tinha aquela coisa, que o pessoal que ia para lá, não trabalhava. Mas não era um não trabalhar no sentido de não vai dar aula; era assim: não vai enfrentar a dificuldade que é a escola. Isso era mal visto, por exemplo. "Por que aquele pode e eu não?" Enfim, criou uma divisão, né? Agora, eu acho que se você tiver um projeto, uma proposta de trabalho, é mais do que legítimo você trabalhar num jeito diferente, se é projeto, tem que ser diferente. (Célia Borges, 
outubro de 2012)

Essa "divisão" apontada por Célia Borges estaria assentada no fato de que a EJA nas EMEFs era organizada segundo o modelo escolar das crianças e adolescentes e as condições de trabalho docente enfrentavam diferentes desafios. Muitos professores lotados nas unidades escolares completavam sua jornada de trabalho na modalidade por meio do processo de atribuição de aulas da rede, ou seja, tinham parte das aulas no Ensino Fundamental para crianças e parte para jovens e adultos. Para atribuição de aulas, os professores concorriam da seguinte forma: primeiro escolhiam os professores Titulares, depois os Adjuntos e, por último, os Contratados ${ }^{31}$. Em cada etapa, eles eram classificados segundo a pontuação sobre seu período de experiência e sua formação. Esse sistema, para muitos, limitava a escolha de lotação e horários. Por ser um processo anual, também propiciava pouca estabilidade dos docentes nas escolas.

Já os professores dos CEMES não concorriam às vagas que ocupavam dessa mesma forma, sendo professores concursados, que trabalhavam em EMEFs como os demais, passavam por processo seletivo interno às DREs e Centros, que buscariam maior adequação do perfil docente ao projeto desenvolvido nas unidades.

Após serem selecionados, os professores eram designados para a vaga, passavam por avaliação anual que condicionava sua permanência. A designação dos professores seria um recurso da SME para propiciar maior estabilidade do quadro docente daquelas unidades de ensino e compô-lo com profissionais com maior experiência e habilidade para trabalhar com EJA.

A reflexão de Célia Borges sobre as condições de trabalho docente diferenciadas nos CEMES também está relacionada ao período de formação e reuniões de que os profissionais dispunham. Para organização do trabalho coletivo, o projeto original dos CEMES já previa semanalmente um período destinado à reunião dos professores, que seria mantido em sua implementação nas gestões posteriores. Esse horário atenderia às reivindicações docentes que ecoavam já na gestão Erundina (1989-1992) nos Projetos Alternativos das Escolas e Frente do Funcionalismo. Sua existência, porém, reforçaria a "divisão" apontada pela entrevistada, pois os processos de seleção e organização do trabalho teriam sido recebidos com desconfiança da

\footnotetext{
${ }^{31} \mathrm{Na}$ época os titulares eram concursados de acordo com estatuto próprio do magistério. Os professores adjuntos eram contratados por processo seletivo em caráter temporário, e os contratados por contratos emergenciais.
} 
categoria docente quanto aos critérios adotados.

Esses fatores do fluxo das políticas seriam o pano de fundo para a avaliação dos CEMES. No fluxo dos problemas, verificamos que indicadores sobre a condição da EJA e as ações do governo anterior também contribuíam para sua ascensão à agenda decisional.

Constatava-se a defasagem entre os números de matrícula, os baixos índices de conclusão, as altas taxas de reprovação e evasão dos educandos nas diferentes propostas da modalidade na rede. Elas reiteravam a percepção de que os CEMES necessitavam ser revistos. Ao lado dessa avaliação desenhava-se uma nova proposta:

(...) Na nossa projeção de trabalho, nós tínhamos aí o restabelecimento do MOVA, a questão do Noturno, do Projeto do Noturno, e o CEMES para transformar em CIEJA. Quando a gente foca na questão do CIEJA, a primeira coisa, o primeiro princípio era entender que esses alunos, eles tinham direito ao ensino presencial; então, queríamos aí reformar a situação, retirar esses CEMES que funcionavam à noite, e voltar com os espaços no noturno, o Regular Noturno; foi uma das primeiras medidas. Nós visitamos aí as escolas que tinham o CEMES e teve uma escola que foi bastante interessante o processo, porque quando a gente anunciou que não seria mais o CEMES, houve aí toda uma rejeição a essa mudança. Os professores também não concordavam que acabasse com o CEMES, mas nós não queríamos acabar com a Educação de Adultos, nós queríamos que o CEMES fosse colocado no devido lugar dele; ou seja, em anexo às escolas, onde ele pudesse funcionar. (...) Nós fomos até as escolas, e aí nós conversamos com os alunos e explicamos qual que seria a ideia de tornar a Educação de Adultos muito melhor para eles, eles teriam lá o professor todos os dias, para que eles pudessem ter as explicações devidas, um mediador, um professor-mediador mesmo nessa questão do aprendizado. (Marisa Darezzo, dezembro de 2012)

Um ponto a ser destacado no relato de Darezzo é a proposta inicial de SME de "retirar" os CEMES e anexá-los às escolas. Vinculá-los às escolas implicaria em desconstituir os espaços, muitos deles improvisados até então, e o regime diferenciado de trabalho docente. A reação dos professores e alunos diante dessa avaliação induziu a permanência de alguns CIEJAs nos prédios em que estavam que, se por um lado os afastava da realidade das EMEFs, por outro possibilitava que desenvolvessem uma identidade própria.

As entrevistas com Roseli Pereira e Célia Borges revelam a percepção das educadoras de que a avaliação foi usada como uma espécie de justificativa para escolhas já realizadas, que implicariam no fim dos Centros.

De fato, o documento de avaliação dos CEMES seria publicado por SME junto com a proposta dos CIEJAs, cuja justificativa pautava-se na leitura negativa sobre seus dados de evasão. Dessa forma, o uso dos indicadores na política "seria como uma espécie de 'placebo' junto da opinião pública para sustentar a convicção de que as medidas tomadas constituem as 
'terapêuticas' mais ajustadas aos problemas que é preciso resolver" (BARROSO, 2009, p.990).

Nesse período, o SENAC já desenvolvia diferentes projetos de EJA e de educação integrada à qualificação profissional ${ }^{32}$. Vislumbrando-se determinado projeto de integração entre educação básica e profissional é que mais tarde, entre 2001 e 2002, seria realizada uma pesquisa nos CEMES sobre o perfil dos Centros, educadores e educandos.

Então, houve naquela ocasião, na prefeitura da Marta, uma grande interface entre o
SENAC e os órgãos públicos, tanto estaduais, quanto municipais; e o SENAC é uma
instituição, como é que eu vou dizer, muito comprometida com a educação e pessoas
de certo estrato socioeconômico, camadas sociais, não importa. De um modo geral,
no Brasil inteiro, é uma instituição bastante comprometida, e tem esse papel social,
tem que dar resultado bom para a vida das pessoas, não importa o partido político,
independe de tudo isso. Então, como Agência Social de Educação Profissional, ela
sempre faz esses contatos. Nessa ocasião, havia uma história de insucesso, na
Educação de Jovens e Adultos; e também, grande evasão e um desestímulo por parte
dos alunos, porque não estava acontecendo nada, além de não estar ensinando coisa
nenhuma, também não os preparava para coisa nenhuma; então, vamos dizer assim,
o resultado social era muito frágil e negativo. Então, a gente fez algumas reuniões, e
tal; e qual era a expectativa? Porque não fazermos Educação Profissional junto?
(Maria Teresa Nori, dezembro de 2013)

Embora Darezzo apontasse a importância do professor mediador nos Centros e Tereza Nori confirmasse a percepção de que os CEMES "não estavam ensinando coisa nenhuma", o descompasso entre as necessidades educativas dos jovens e adultos e a metodologia dos cursos semipresenciais também já era motivo de reflexão e ação dos próprios Centros, que desenvolviam arranjos específicos para dar sentido a suas práticas. Grupos de alfabetização e pós-alfabetização foram constituídos ao longo do tempo em diferentes unidades e em formatos também diversificados, surgiram ainda aulas temáticas, oficinas de arte, de redação, matemática, artesanato, entre outros. É o que expressam as entrevistadas Célia Borges e Roseli Pereira, respectivamente professora e orientadora pedagógica do CIEJA Butantã, além de Êda Luiz, coordenadora geral do CIEJA Campo Limpo.

Arte, a gente nunca fez à distância... isso foi uma das condições. Olha que gente tinha certa liberdade de impor condições. "Se for para fazer prova, eu não vou ficar”. Umas coisas assim. A gente montou oficinas; que, na verdade, não eram muito oficinas não, eram aulas mesmo, porque tinha uma estrutura, a gente fazia a sensibilização, depois o desenvolvimento de alguma prática e avaliação no final. A aula tinha sempre uma mesma estrutura, era uma hora e meia. Os alunos, quando

\footnotetext{
${ }^{32}$ Programa Profissão era realizado com parceria entre o SENAC-SP, SENAI, Centro de Educação Tecnológica Paula Souza e da Secretaria de Educação do Estado de São Paulo. O programa visava preparar os jovens da rede pública para o mercado de trabalho. O Programa SENAC-SP de Educação e Cidadania: Alfabetização de Jovens e Adultos visava promover alfabetização até a antiga $4^{a}$ série, desenvolvido em diferentes cidades do estado de São Paulo. Os dois programas variavam não só em relação ao público a que se dirigiam, como também em relação aos referenciais adotados, enquanto o programa de alfabetização pautava-se nas concepções freirianas, o programa de profissionalização se aproximava do currículo por competências.
} 
entravam aqui, já tinham que escolher as oficinas em Arte... Então, eles faziam sempre Arte e mais uma disciplina para começar, a outra eles podiam escolher. E aí eles iam criando vínculo com a escola; às vezes, tinha turma, que não era turma, era individualizado o atendimento, mas eles se conheciam aqui no pátio e eles faziam a aula já sempre juntos.(Célia Borges, outubro de 2012)

A única coisa que tinha presencial eram as aulas de Alfabetização e Módulo 2 e 2-A, na pós alfabetização, e as Oficinas de Arte, porque as professoras de Arte se reuniram e falaram: Não dá para a gente dar aula de Arte com apostila. (Roseli Pereira, novembro de 2012)

E aí o quê que os alunos começaram... Aluno, né, sabiamente: você tem 10 minutos para tirar a dúvida, o outro tem mais 10, mais 10 e fizeram assim, o que o Paulo Freire fala tanto, que é o que? Você só aprende na troca, na discussão, na reflexão, em um determinado posicionamento de todos no grupo. Então eles fizeram assim, juntavam seis, dava 60 minutos, e você estava dando uma aula de 60 minutos. Porque antes era para tirar a dúvida, era 10 minutos cada um. Tinha até um tipo de um reloginho que marcava os 10 minutos. Acabou, tchau. Feito. Fazia a sua avaliação. E era incrivelmente difícil assim. E os alunos ainda falavam que eles aprendiam melhor quando tinha esse professor. Eu falei: Gente, então... Aí independente de SME, eu fiz o primeiro grupo de alfabetização, porque alfabetização não dava para funcionar assim. ( $\hat{E}$ da Luiz, dezembro de 2012)

Os relatos apontam que alunos, professores e gestores reconheciam as dificuldades de manter a metodologia dos CEMES, em que se estudava individualmente as Unidades de Estudo e se frequentava os Centros para tirar dúvidas e fazer provas. Nesse sistema, imperava a concepção de que educação era a transmissão de conhecimento, relacionava-se à memorização de conceitos.

Amparados na autonomia escolar, os CEMES Campo Limpo e Butantã, enfrentavam as deficiências dessa concepção, fomentando alternativas que a superassem. A "solução" encontrada pelos estudantes para "aprender melhor" confirmava a importância da formação de grupos para aprendizagem, ratificando, como citou Êda Luiz que "só aprende na troca, na discussão, na reflexão, em um determinado posicionamento de todos no grupo".

Alguns dos arranjos das próprias unidades de CEMES contribuiriam, portanto, para promover maior aceitação das soluções que seriam propostas por DOT/SME, como a necessidade de formar grupos-classe. A mudança do ensino semipresencial para o presencial, então preconizada por aquela gestão, seguia também as diretrizes de democratização do acesso à educação como direito, como revelou a entrevista com Marisa Darezzo.

A adesão dos educadores dos Centros ao Projeto CIEJA não deixou de ser conflitante. Roseli Pereira apontou que havia uma visão da DOT EJA de que a mudança não poderia ocorrer com os mesmos atores nas unidades de ensino. De fato, observamos que parte das equipes dos CEMES não permaneceu nos CIEJAs, pois as designações de seus profissionais 
foram cessadas, sendo necessário que todos passassem novamente por processos seletivos. Essa ação respondia tanto às acusações de favorecimento na seleção de docentes e nas suas condições de trabalho em relação aos processos seletivos anteriores, quanto à necessidade de montar um quadro de profissionais mais afinados à nova proposta.

Uma vez que diversas características dos CEMES eram percebidas como problemas, foi necessária a escolha de alternativas para solucioná-las. Elas remontavam, em grande parte, àquelas modificações estruturais, organizacionais e pedagógicas para EJA na gestão de Erundina (1989-1993) ${ }^{33}$, como também revelam os discursos das entrevistadas e documentos da SME.

Flexibilidade na duração dos cursos e tempo de aula diária, autonomia da escola para compor a jornada de trabalho dos docentes, incluindo espaços de formação coletiva, entre outros aspectos, eram apontados como soluções desejáveis no Projeto CIEJA (SME, 2001, p. 18). Essas soluções estariam disponíveis junto a comunidades políticas e atores que participaram da primeira gestão do PT na cidade, como a própria diretora de DOT EJA à época, Marisa Darezzo e demais entrevistadas. Organizações sociais como Veredas, Ação Educativa e Instituto Paulo Freire também propunham soluções para a modalidade de ensino, pois atuavam na formação de professores do MOVA e participavam dos debates para reorganização curricular da EJA.

O SENAC-SP também contribuiria significativamente para a constituição dos CIEJAs, já que desde o início da gestão de Marta Suplicy mantinha-se em contato com a SME-DOT e redigia grande parte dos documentos que dariam corpo ao projeto. A instituição agregaria o olhar sobre os estudantes enquanto trabalhadores, atribuindo à formação dos Centros a função de prepará-los e integrá-los no mercado de trabalho. No início das conversas entre SME e SENAC-SP, Teresa Nori destaca:

A ideia inicial é muito parecida com o que o ProJovem propõe hoje.Veja, o CIEJA foi um inspirador do ProJovem, ele vem antes... Então, porque a ideia deles era fazer o que eles fizeram, né, bota aqui o curso profissional, e depois junta mais uma parte, tipo Lego; mas, aí a gente fez uma contraposta. Eu não acredito em Currículo Lego, então a gente começou a dizer: Olha, a gente precisa estruturar o currículo de forma integrada, não juntada, mas integrada; então, vamos rever a legislação de EJA e vamos ver. Primeiro, fazer uma grande pesquisa, para ver as demandas, (...)fazendo uma pesquisa de mercado a gente vê onde eles poderão entrar no mercado de trabalho com mais chances. À medida que a gente faz o Itinerário, que é essa a proposta da legislação, a gente vai, pode antecipar, com sucesso, a entrada no

\footnotetext{
${ }^{33}$ Elencamos no capítulo 3, as alternativas propostas à EJA na gestão de Luiza Erundina.
} 
mercado de trabalho, porque ele vai se formando gradualmente, diferentes qualificações, até que ele possa chegar ao estágio que ele quiser. (Maria Teresa Nori, dezembro de 2013).

A comparação que Nori faz entre o Projeto CIEJA e o Projovem embasa sua percepção de que o CIEJA teria inspirado outros programas que articulam EJA e qualificação para o trabalho nos últimos anos, citando também o PROEJA. Nessas comparações, Maria Teresa Nori destaca que o CIEJA teria avanços consideráveis em procurar integrar a formação básica à qualificação profissional, em vez de concebê-las como eixos complementares, mas fragmentados.

A assessoria do SENAC-SP compreendia que a concepção da educação ao longo da vida seria vinculada à necessidade de articular os conhecimentos escolares com as necessidades de aprendizagem constantes devido às mudanças no cenário do trabalho e emprego em meio à intensificação da economia globalizada.

As transformações sociais e tecnológicas em curso no mundo globalizado levam, necessariamente, a uma reorganização do mercado de trabalho que, por sua vez, interfere diretamente na vida social, econômica e afetiva dos jovens e adultos, obrigando-os a atender às novas exigências de perfil profissional que o mercado impõe - um profissional com maior formação, flexibilidade, qualificação e educação geral, que reflita sobre seu trabalho e que tenha iniciativa e criatividade ${ }^{34}$. (SME, 2002, p.2)

A formação profissional era compreendida de maneira aproximada às demandas do mercado de trabalho, ou seja, preparação dos estudantes para ocupar os postos de serviço. A integração entre educação básica e educação profissional era um desafio que trazia diferentes conflitos, inclusive, entre SME e o SENAC-SP, conforme expressam as entrevistas com Maria Teresa Nori e Darezzo. Havia uma clara tensão sobre a realização do convênio com o SENACSP para desenvolvimento de atividades educativas na rede pública.

(...)Porque, o mercado, ele vem modificando muito, e naquela época a gente já tinha bem essa avaliação da necessidade das pessoas se prepararem para os postos de serviço, buscar alternativas de profissionalização, para ser inserido realmente no mercado. Então, nós fizemos todo o possível para tentar articular a Educação Profissional, nós tínhamos o SESC, tínhamos o SENAC, e nós acabamos por optar pelo SENAC, que já tem um histórico; e aí foi também muito complicado, porque tem aquela coisa do Sistema $S$. "Ah, o Sistema $S$, que pega todas as verbas do governo". Então, foi difícil das pessoas poderem entender; mas, por outro lado, a Secretaria, e nem os educadores tinham aí essa habilidade, essa competência de trabalhar com a Educação Profissional. Então para a gente também era um aprendizado, e foi aí que a gente começou a trabalhar com isso... foi contratada a assessoria do SENAC. Os técnicos mesmo da Educação Profissional, e eles começaram a se informar, a pensar quais seriam os itinerários formativos, e como que se daria essa articulação com os novos professores; porque os CIEJAs foram lá para começar a funcionar nos

\footnotetext{
${ }^{34}$ Justificativa do Projeto CIEJA, 2002.
} 
espaços, que até hoje eles existem... (Marisa Darezzo, dezembro de 2012)

A impressão que tinha o pessoal do DOT, assim que começaram os primeiros contatos, é que o SENAC era uma instituição burguesa, neoliberal; e nada os convencia de que o SENAC não tem nada a ver com isso. Não é que é apolítico, nada é, mas que não tinha esse tipo de opção. A opção é atender a todos, porque é uma Agência de Educação, é uma Agência Social, comprometida com a sua missão; mas, quando eles faziam o lado político, eles deixavam a ideológica, que deveria estar unindo todo mundo, então foi muito difícil. (...) Então, a nossa proposta, o trabalho preponderante era "vamos garantir acesso à possibilidade de se formar e a oportunidade de sobreviver, de viver com dignidade da sua profissão, isso é um direito de todos; vamos, né, abrir para todo mundo, trabalhando com profissões das quais eles realmente tinham chance de trabalhar, e não uma coisa artificial”. Eu me lembro que numa das reuniões com o pessoal da Secretaria, quando nós dissemos quais eram as profissões, garçom, manicure... “Ah, mas essas profissões?” Eles olharam com desdém, sabe; me estranhou muito, porque eles eram petistas, eu não esperava por isso. Esperava menos preconceito (Maria Teresa Nori, dezembro de 2013).

A fala de Nori denota que sua compreensão sobre qualificação profissional alicerçavase na ideia de que prover condições de os estudantes ingressarem no mercado de trabalho era melhorar sua qualidade de vida. Ela ainda revela a percepção de que membros da SME não valorizavam determinadas profissões, o que compreende como "preconceito".

Os cursos de qualificação profissional oferecidos para os CIEJAs alimentavam as discussões acerca das profissões e seu status na sociedade. Nori citou que determinadas profissões, muitas vezes não bem reconhecidas, oferecem salários equivalentes às demais. Nota-se que a desvalorização de profissões pelos sujeitos envolvidos na idealização dos CIEJAs refletia também sua desvalorização financeira no mercado competitivo e uma divisão social do trabalho que, de certo modo, reforçaria a desigualdade entre as classes.

Em cada unidade de CIEJA seria inserido um Itinerário Formativo diferente, buscandose atrelar os cursos aos arranjos produtivos locais. A qualificação profissional concentrava-se em cinco setores, a cada módulo do Ensino Fundamental correspondia um curso.

Quadro 2 - Cursos dos Itinerários Formativos

\begin{tabular}{|c|c|c|c|c|c|}
\hline Módulo & $\begin{array}{c}\text { Serviços de Atendimento e } \\
\text { vendas }\end{array}$ & Serviços Domiciliares & Alimentação & $\begin{array}{c}\text { Lazer e } \\
\text { Desenvolvimento Social }\end{array}$ & Beleza \\
\hline I & Telefonista (básico) & Porteiro & Auxiliar de cozinha & $\begin{array}{c}\text { Monitor de oficinas de } \\
\text { lazer }\end{array}$ & Manicure e pedicure \\
\hline II & $\begin{array}{c}\text { Vendedor- atendente de } \\
\text { estabelecimentos } \\
\text { comerciais }\end{array}$ & $\begin{array}{c}\text { Auxiliar de serviços } \\
\text { gerais - pequenos reparos }\end{array}$ & $\begin{array}{c}\text { Atendente de } \\
\text { lanchonete/ } \\
\text { lancheiro-chapista }\end{array}$ & $\begin{array}{c}\text { Monitor de recreação } \\
\text { e cultura }\end{array}$ & $\begin{array}{l}\text { Auxiliar de } \\
\text { cabeleireiro }\end{array}$ \\
\hline III & $\begin{array}{l}\text { Recepcionista de clínicas } \\
\text { e consultórios }\end{array}$ & $\begin{array}{c}\text { Prestador de serviços de } \\
\text { manutenção de } \\
\text { edificações }\end{array}$ & $\begin{array}{l}\text { Preparador de } \\
\text { atendente de buffet }\end{array}$ & $\begin{array}{c}\text { Cuidador de crianças e } \\
\text { idosos }\end{array}$ & Cabeleireiro - cortes \\
\hline IV & $\begin{array}{l}\text { Atendente de } \\
\text { telemarketing }\end{array}$ & Zelador & $\begin{array}{c}\text { Cozinheiro } \\
\text { (básico) confeiteiro }\end{array}$ & $\begin{array}{c}\text { Agente comunitário } \\
\text { para saúde e qualidade } \\
\text { de vida }\end{array}$ & Cabeleireiro penteados \\
\hline
\end{tabular}

Fonte: CIEJA. Relatório de Implantação Currículo Integrado Ensino Fundamenta e Profissional (SME, 2003) 
A oferta de cursos remeteria à interseção entre as demandas do mercado de trabalho local; as legislações trabalhistas sobre requisitos de escolaridade das categorias profissionais; a infraestrutura dos Centros e a mão de obra qualificada para educar os estudantes. Essa interface teria sido bastante desafiadora, segundo Nori, já durante o engendramento da proposta dos CIEJAs, que ofereceriam os cursos aos jovens e adultos analfabetos e com baixa escolaridade.

Na Área de Saúde, por exemplo, você não pode oferecer qualificação profissional no nível que os CIEJAs atendem. Eles exigem um grau [de escolaridade] um pouco maior por questão de legislação. Você tem que adequar uma legislação a outra; quer dizer, educação geral e profissional. Quando o projeto foi estruturadinho, arrumadinho e ia começar realmente, a pessoa que veio do Ministério da Educação e a do Trabalho, ficaram encantadas, o pessoal gostou demais da proposta e pediu para não divulgar, porque eles queriam fazer em âmbito nacional. (Maria Teresa Nori, dezembro de 2013).

A observação de Maria Teresa Nori sobre a recepção ao projeto no momento de seu engendramento pode ter reforçado sua visão de que ele influenciaria os programas nacionais ${ }^{35}$, conforme citado anteriormente, justamente, porque equacionava as demandas do mercado de trabalho, a legislação referente à regulamentação das profissões e os níveis de escolaridade dos educandos.

Observamos até esse ponto, portanto, a confluência entre o fluxo da política, o fluxo dos problemas e o fluxo das alternativas. Nesse período de transição entre CEMES e CIEJAs, a implementação das alternativas era realizada concomitantemente à redação do Projeto CIEJA, que seria publicado por SME em junho de 2002, enquanto o decreto que autorizava seu funcionamento seria publicado apenas em 2003.

Esse fato nos revela que as decisões políticas sobre as soluções que seriam adotadas no Projeto CIEJA eram feitas "no meio do caminho" de discussão e transformação dos CEMES, embora estivessem presentes em diferentes comunidades políticas e experiências de EJA há mais tempo.

Vivenciar novas formas de fazer educação de jovens e adultos tem sido um desafio
para muitos, seja para aqueles que formulam políticas educacionais, seja para aqueles
que a constroem, no cotidiano escolar, no contato com os educandos e com a
comunidade educativa. Experiências inovadoras em educação aparecem, em
diferentes instâncias, como respostas para problemas encontrados por educadores e
equipes técnicas no cotidiano escolar e por equipes de órgãos centrais preocupados
com a qualidade da educação oferecida a crianças, adolescentes, jovens e adultos. A
tomada de decisão por mudanças pressupõe colocar em pauta, para discussão, pelo
menos três elementos: clareza dos objetivos a serem alcançados; conhecimento da

${ }^{35}$ Nori faz alusão ao ProJovem e PROEJA. 
realidade social e educacional onde a atividade pedagógica se desenvolve, bem como os sujeitos com os quais se trabalha; e decisão pela mudança. Outro elemento importante, a partir destes três primeiros é a implementação destas mudanças, que traz desafios para o desenvolvimento das ações. (SME, 2003, p.6)

A implementação dos CIEJAs concorrentemente à elaboração do projeto contribuía para diversificação entre essas unidades de ensino desde o início de seu funcionamento. A Revista do CIEJA (2004), publicação que visava fazer um balanço da implementação dos Centros na cidade de São Paulo e condensava relatos de prática de cada unidade, revelava que nesse processo, as mudanças implantadas nos Centros abarcavam diferentes soluções. Elas estariam presentes na gestão de Erundina, seriam provenientes das discussões do GT de avaliação do CEMES, da assessoria do Senac-SP, ou advindas da formação dos educadores. Cada centro escolheria variavelmente algumas delas: a polivalência, a pesquisa de temas geradores na comunidade escolar, a integração entre mundo da cultura e do trabalho, entre outros.

Caberia ao Conselho Municipal de Educação avaliar a implantação do Projeto CIEJA em cada um dos Centros, validando e gerando recomendações para o cumprimento dos objetivos comuns a todos eles. A trajetória dos CIEJAs também revela outros efeitos do descompasso entre a escolha das soluções e sua concretização, como a demora em iniciar os Itinerários Formativos.

Os relatos de Roseli Pereira, Êda Luiz e Célia Borges revelam que contratação da assessoria se traduzia na responsabilização do SENAC-SP pela formulação e execução dos Itinerários Formativos. Essa percepção configuraria atuação da instituição mais como prestadora de um serviço, que propriamente como assessora para os técnicos e docentes integrarem "educação e trabalho". O relato da orientadora pedagógica do CIEJA Butantã naquele período sintetiza algumas das perspectivas colhidas durante as entrevistas:

De certa forma, eles entregaram ao SENAC a formação dos professores, a formação dos alunos e não equiparam os Centros, não formaram os professores no aspecto do inserir o Ensino Fundamental mesmo, as suas áreas, o que as áreas teriam a contribuir. (Roseli Pereira, novembro de 2012)

Essa percepção de Roseli Pereira justifica-se pelo fato de que o SENAC-SP elaborou o material didático dos Itinerários Formativos, que tinham proposta pedagógica diferente daquela até então utilizada nas Unidades de Estudos. 


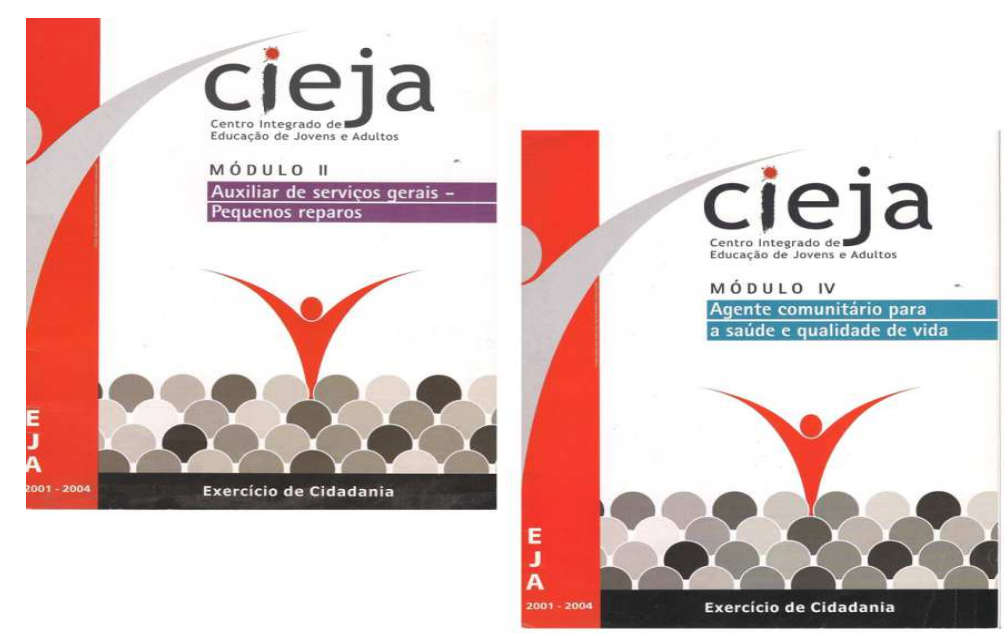

Figura 2 - Apostilas dos Itinerários Informativos

Para cada curso dos Itinerários Formativos foram desenvolvidas apostilas formuladas pela instituição, considerando-se o nível de ensino e qualificação profissional do trabalhador. A assessoria também influenciaria o currículo da formação geral quando o desenvolveu a partir de competências para EJA.

É claro, que a proposta do projeto não era mexer na Educação Geral, mas o que a gente fez foi trazer as competências, porque eles não trabalhavam por competência; e as competências propostas para a EJA, nós não criamos nada, nós pegamos as competências de EJA, vimos onde as competências profissionais podiam melhorar as competências para a cidadania, e onde aquelas competências de cidadania podiam também melhorar a Educação Profissional, essa é a ideia de integração, que foi isso que a gente criou, que eu acho que esse é o grande diferencial, o CIEJA. (...) E por outro motivo, a gente criou um material didático numa proposta pedagógica diferente daquilo que se tem; por exemplo, uma Cartilha, eles tinham um problema tremendo na alfabetização. Depois, nosso material ajudaria, seria até mesmo usado para alfabetização porque alguns professores gostaram da proposta. (Maria Teresa Nori, dezembro de 2013)

Por imposição da legislação, a prefeitura de São Paulo não poderia contratar educadores para EJA que não tivessem licenciatura e, conforme apontou Nori, grande parte dos profissionais que eram instrutores de dos cursos de qualificação para o trabalho não tinham essa formação. O SENAC-SP teria intermediado a contratação dos monitores para resolver esse conflito.Apostava-se em sua dupla docência com os professores dos CIEJAs para integrar o ensino escolar e a qualificação profissional. No entanto, a integração desses monitores também foi desafiadora, conforme os relatos coletados. Para Nori, havia uma percepção dos professores do CIEJA de que o monitor de qualificação profissional não teria requisitos suficientes para dar aulas. Ao mesmo tempo, o SENAC-SP acreditava que a formação pedagógica dos professores não era suficiente para qualificar o trabalhador. 
“Olha, vocês percebem, vocês estão pensando, vocês acham que manicure é inferior
a professor. Bom, vocês sabem que uma manicure pode até ser melhor remunerada”
Porque uma proposta que eles fizeram, é que eles tinham professores ociosos, então
eles queriam que a gente desse um curso de 15 dias para esses professores, para
eles serem professores no Curso de Manicure. Aí, definitivamente, a gente ficou
irritado; e eu disse claramente o seguinte: "Você faria as unhas com uma manicure
que tem só 15 dias de curso, sem nenhuma experiência? Embora conheça História,
Geografia, Português, Matemática, seja Alfabetizadora, etc. e tal, você daria a sua
mão para manicure?” Na hora, o que estava sentado com a mão na mesa puxou a
mão, foi muito espontâneo. Eles não estavam entendendo muito bem, a despeito de
ter uma ideologia tão similar à nossa - acesso a todos, democracia de verdade,
oportunidade - ainda havia muitos preconceitos. (Maria Teresa Nori, dezembro de
2013).

Esse impasse seria reproduzido nos Centros e solucionado também de maneiras diversas. Segundo a educadora entrevistada Célia Borges, que trabalhava nos CIEJA Butantã, enquanto as discussões sobre a integração entre o mundo da cultura e o mundo do trabalho ocorriam nos CIEJAs para integração da qualificação profissional no currículo, o material referente aos Itinerários Formativos era elaborado independentemente pelo SENAC-SP e tardaria a chegar aos Centros, bem como os instrutores contratados. Célia Borges comparou os cursos do Itinerário Formativo com "uma espécie de treinamento para os alunos", devido ao curto período e maneira como transcorreu no centro.

Foi no fim [do ano letivo] que eles chegaram, eu acho que lá para setembro, outubro, entendeu? E aí, naquele ano, o que aconteceu? O que a gente tinha que fazer já tinha sido bastante encaminhado e meio que tentamos acompanhar no processo o que eles trouxeram pronto. Não houve esse diálogo, não houve um "Vamos preparar". A gente ajudava, às vezes dava certo, às vezes não dava, dependia muito do professor. (...) Ficou como se fosse um treinamento para os alunos, acho que foi bem isso, um treino, né? E a nossa proposta era mais formação e quando a gente fala em formação é mais amplo do que treinar. (Célia Borges, outubro de 2012)

Na entrevista, Célia Borges faz uma distinção entre o "treinamento" e a "formação". Entendemos que essa distinção se refere às bases do Projeto CIEJA, que no plano dos discursos pretendia que os Itinerários Formativos fossem desenvolvidos em contínuo diálogo com os temas trabalhados no Ensino Fundamental, não como um curso extra, conforme também apontou Teresa Nori quando se referiu à necessidade de evitar um currículo "do tipo lego".Segundo o depoimento de Célia, o descompasso entre a idealização dos Itinerários Formativos e sua implantação teve efeito contrário. No entanto, a educadora também considerou que, apesar dos atrasos e falhas no diálogo com o SENAC-SP, foi importante discutir a relação entre escolarização e trabalho durante esse período. Também deixou claro que, dependendo da postura profissional e afinidades entre os monitores do Itinerário 
Formativo e os docentes, os cursos tiveram maior ou menor sucesso.

Marisa Darezzo (diretora da DOT EJA) reconhece em sua entrevista a difícil articulação entre os professores dos CIEJAs e os monitores contratados, em parte devido à novidade daquela proposta, em parte por certa resistência de alguns docentes trabalharem conteúdos diferentes e com profissionais que não eram do magistério público municipal. A entrevistada ainda citou que a dupla docência idealizada foi bastante difícil de ocorrer, pois requeria um planejamento prévio das ações educativas.

Êda Luiz, do CIEJA Campo Limpo também avaliou em seu relato que houve a carência de um tempo de planejamento de como se efetuaria a dupla docência. Revela que diferentes Agentes Comunitários, que ainda atuam em sua região, foram formados pelos Itinerários Formativos no CIEJA, mas o material do SENAC "veio pronto" e foi um desafio integrá-lo ao planejamento que já estava sendo desenvolvido naquela unidade.

Outro problema apontado por Marisa Darezzo e Maria Teresa Nori, que impactou na implantação dos Itinerários Formativos nos CIEJAs, refere-se à falta de recursos para equipar os Centros para oferta de cursos. Não havia infraestrutura e investimento suficientes para que desde o início a integração entre educação geral e profissional pretendida transcorresse de maneira adequada.

Uma coisa que a gente alertou bastante. Primeiro, você não pode oferecer um Curso de Natação, se você não tiver uma piscina. Não é isso? Pois bem, eles não tinham cozinha; veja, ainda hoje a Área de Alimentação é uma área que tem grande oferta de emprego, certo? Profissionais bem preparados se saem bem, têm oportunidade de carreira. No entanto, só algumas escolas oferecem condições, de estrutura mesmo, instalações, e tudo mais; são cursos caros, porque embora a profissão não seja glamourosa e "limpa", como eles falavam, ela é cara. A formação é mais cara que na Área de Informática, por exemplo; com a Informática você tem alguns computadores, você faz; mas, em cozinha, você tem que ter além das instalações adequadas, toda a higiene e a infraestrutura necessárias, você tem que ter os insumos e assegurar que sejam armazenados corretamente e tudo mais e eles não tinham essa infraestrutura. (...) A previsão do projeto foi feita, mas aí é que está, em contrapartida, de providenciar cabia a eles, nós não podíamos interferir. (...) E eu sei que de lá para cá, desde que a gente implantou os Itinerários, e tudo mais, acabou mudando, até por conta das instalações. (...) Me diziam "Olha, o pessoal escolheu a Área de Alimentação e não tem cozinha, arranjaram um fogão Dako para botar numa copa. Isso não pode. Não dá como a gente dar conta de um Curso de Gastronomia, gente!” (...) Então, havia muita precariedade no início; e também, no início, nós não trabalhávamos com Informática, simplesmente, porque não havia rede, era impossível dar qualquer coisa de Informática. (Maria Teresa Nori, dezembro de 2013)

Segundo Marisa Darezzo, a não renovação da parceria com o SENAC- SP no final de 2004 foi devida à falta de verbas, e à dificuldade de manter cursos sem a infraestrutura 
adequada. Os Itinerários Formativos passaram a depender da mobilização de novas parcerias pelos próprios CIEJAs e da atuação dos próprios educadores. Roseli Pereira também revela que essa tarefa seria cada vez mais desafiadora e, ao longo do tempo, acabaria abandonada.

Então, como ele foi tão assim repentino, do mesmo jeito que veio, foi, né? A impressão que nós tivemos é assim: Pronto. No ano seguinte, já não renovaram o contrato com o SENAC, porque uma das coisas que colocaram em dúvida, foi o valor que esse convênio estava. E o SENAC deixou, mais ou menos, claro: "O nosso papel era esse, fazer o diagnóstico, montar o material e formar. Agora, é com vocês...” Aí eles fizeram até uma tentativa de fazer uma seleção na rede dos professores que tinham alguma qualificação outra que não fosse pedagógica. Então, tem um professor que dá aula de Ciências, mas ele é químico, ele pode fazer o Itinerário Formativo de Beleza, que era para trabalhar essa questão de composição de produtos, essa questão toda. Tem professor que tem uma empresa, então ele pode dar Itinerário de Vendas. Aí foram muito poucos. (...) O que sobrou [dos Itinerários] foi o que os nossos professores estariam capacitados a fazer; que aí ficou o Itinerário Formativo de Informática. E também foi pensado pela Equipe do SME como Itinerário; ou seja, eu parto das noções básicas e chego a software, hardware; e consigo, nos quatro anos de trajetória do aluno do CIEJA, que ele amplie o seu conhecimento, até poder trabalhar com isso. Mas nunca aconteceu. (Roseli Pereira, novembro de 2012)

No final da gestão de Marta Suplicy, tinham sido implantadas treze unidades de CIEJAs na cidade, cada uma desenvolvia as alternativas propostas de maneira singular, guardavam, porém, identidade estrutural, organizacional e pedagógica, visando integrar "o mundo da cultura" ao "mundo do trabalho".

Bem como ocorrera na gestão de Luíza Erundina, buscava-se a descentralização das decisões e respeito à autonomia. Caberia a cada unidade avaliar e desenvolver as alternativas propostas, encontrando diferentes formas de empreendê-las e atribuir sentido às práticas.

Cada um dos Centros, embora com referenciais teórico-metodológicos e objetivos comuns, foi criando formas de desenvolver o trabalho, de modo a melhor atender os jovens e adultos que buscam este espaço de formação. (...) Muitas foram as dúvidas que surgiram durante o processo de implementação dos CIEJA, mas a busca por respostas deu-se sempre no coletivo, seja nos espaços de cada Centro, seja na relação com os demais, numa troca de informações e de conhecimentos construídos a partir da prática de cada um. (SME/DOT, 2004, p.6-7)

Durante a implementação do Projeto CIEJA, a realidade dos Centros e dos estudantes fariam emergir outras necessidades, dificuldades e soluções para modalidade no município. As experiências desse processo deveriam compor, na gestão seguinte, o Novo Projeto CIEJA, conforme o Parecer n. 34 do Conselho Municipal de Educação (CME, 2004). 


\subsection{Gestão de José Serra (PSDB) e Gilberto Kassab (DEM) (2005-2008)}

Após uma acirrada disputa com Marta Suplicy (PT), que buscava a reeleição em São Paulo, José Serra,do Partido da Social Democracia Brasileira (PSDB), assume a Prefeitura em 2005, com o médico José Aristodemo Pinotti ${ }^{36}$ para dirigir da SME, por força de alianças partidárias.

A gestão de Serra buscaria diminuir despesas e aperfeiçoar resultados. Observa-se nesse sentido, a reestruturação e redução das Coordenadorias da Saúde e Educação junto às Subprefeituras.O "diagnóstico"da SME sobre o cenário educacional encontrado na cidade, relatado após seis meses de gestão de Pinotti, indicava que medidas eram necessárias para melhorar a eficácia das ações educativas. O relatório traduzia uma visão gerencialista de qualidade da educação, ao apontar um paradoxo, segundo o qual as escolas possuiriam boas condições estruturais, mas resultados precários no que se refere ao desempenho dos estudantes nas avaliações de larga escala, como o SAEB e o PISA.

Essas condições demonstram claramente as razões do paradoxo entre boas condições e resultados precários. Elas são a base das correções que iniciamos a partir do segundo mês de gestão, com projetos executivos baseados direta ou indiretamente na correção de toda essa problemática. (SME, 2005, p.17)

A "correção" a que se refere o excerto acima remetia à reorientação do gerenciamento dos recursos humanos para resolver o "problema da qualidade da educação". Esse problema foi evidenciado por oito indicadores que seriam as causas do paradoxo apontado: a predominância de um conceito de educação como transferência de conhecimento; a ausência de avaliação e controle social; a demanda não atendida nas creches; a saúde precária das crianças como uma das causas do fracasso escolar; os gastos com os Programas de Formação de Professores; a falta de professores e professores que faltavam; os 70\% das escolas com três turnos diurnos; o "caos administrativo, falta de priorização e interferências externas fora de controle.” (SME, 2005, p.12-17). Neste último ponto, faz-se referência à atuação das ONGs que possuíam projetos e parcerias com as unidades escolares "sem qualquer autorização do nível central ou até das Coordenadorias" (SME, 2005, p.12-17).

\footnotetext{
36 José Aristodemo Pinotti pertencia ao partido da base aliada do governo. Foi indicado pelo Partido da Frente Liberal (PFL), do vice-prefeito eleito na chapa de Serra, o então deputado federal Gilberto Kassab.
} 
Como alternativas para o problema da "falta de professores", o documento também apresentava a diminuição das Coordenadorias Regionais de 31 para 13, o que implicou numa maior centralização administrativa.Nesse período, notamos uma concepção de qualidade de educação bastante aproximada da administração empresarial, mais do que embasada em concepções pedagógicas, fundamentavam-se no controle dos recursos humanos, aumento de carga horária dos estudantes, centralização de decisões, avaliação de resultados.

Empenhou-se em fazer um reconhecimento da realidade encontrada, detectando a
necessidade de transformar essa situação, implicando também refletir sobre as
instâncias deste sistema educacional, em sua estrutura e funcionamento, mecanismos
que podem contribuir para o êxito de nossos projetos, estabelecendo diretrizes
políticas para executá-los. Acompanhamento conjunto e articulado da Proposta de
Formação da DOT 2005, com Círculo de Leitura e Escrita, Divisão do Ensino
Fundamental e Médio, Divisão de Educação Infantil. GESTÃO PEDAGÓGICA -
Aprendizagem na Escola: ponto de partida e ponto de chegada em parceria com as
Coordenadorias de Educação e o Trio Gestor: Supervisor Escolar, Coordenador
Pedagógico e Diretor de Escola. (SME, 2005, p. 44)

A situação de que trata o excerto acima não explicita os problemas que conduziriam à necessidade de transformação, no entanto, aponta para o estabelecimento de novas diretrizes políticas para o "êxito" dos projetos em funcionamento. A mudança de governo propiciava novos rumos das políticas de EJA. No entanto, o relato de Darezzo confirma a continuidade das propostas para modalidade no município em reconhecimento às soluções escolhidas e implantadas na gestão anterior para aquela modalidade. A continuidade do MOVA era também reflexo de sua institucionalização, já a permanência dos CIEJAs justificava-se pelo "feedback" positivo de diferentes grupos.

Mas, depois que terminou a Administração, aí a gente acabou voltando para a escola. Antes de eu voltar para a escola, eu tive um tempo para tentar trocar com a Administração que estava chegando à época, e eu acho que foi uma coisa muito legal para a gente ali de DOT. (...) Você ter uma avaliação positiva do trabalho que foi feito e um reconhecimento. E acho que foi muito bom para a gente ouvir dizer que eles acharam que teve um movimento muito bacana e continuaram com isso, com esse projeto, mudaram algumas coisas, mas o MOVA está continuando aí, o Noturno, o CIEJA. (Marisa Darezzo, dezembro de 2012)

Importa observarmos, portanto, que condições específicas da EJA seriam transformadas em problemas naquela e na próxima gestão, apontando concepções, demandas e caminhos diferentes do governo anterior para as mesmas propostas de ensino. Os índices de aprovação, reprovação e evasão dos cursos na modalidade e a fragmentação das ações sustentariam as mudanças previstas, recorrendo a soluções relacionadas ao currículo e à organização da EJA.

Para concorrer às eleições do governo de Estado, José Serra (PSDB) deixou o mandato 
da prefeitura em 2006, assumindo seu vice-prefeito, Gilberto Kassab do Partido Democratas (DEM), que nomeou Alexandre Schneider como Secretário Municipal de Educação.

A entrevistada Romy Schinzare revelou que passaria a integrar a DOT EJA como técnica no final da gestão de José Serra e em pouco tempo assumiria a direção de DOT EJA. Segundo Schinzare, a percepção de que a EJA era "tratada como 50\% do Ensino Regular" em muitas escolas, a caracterizava como mera aceleração dos estudos. A semestralidade era compreendida como barreira para o desenvolvimento dos projetos pedagógicos de forma mais contínua. A ex-diretora de DOT EJA também menciona a dificuldade burocrática para a constituição de turmas nas escolas e sua avaliação final.

O professor levava quase um mês para receber os documentos oficiais, como o diário de classe, lista de alunos então, você levava ali uma média de quase 30 dias para botar o negócio para funcionar, e mais 30 para fechar, porque tinha as comissões finais de classe, fecha o diário, fecha isso, tinha toda uma burocracia, que se repetia a cada seis meses. (Romy Schinzare, março de 2013)

De fato, o caráter semestral do curso, embora favorecesse o acesso dos jovens e adultos ao ensino, que teriam duas oportunidades de ingresso nas escolas durante o ano, dificultava o seguimento dos mesmos padrões para atribuição de aulas e administração escolar do Ensino Fundamental das crianças. No meio do ano, muitos estudantes jovens e adultos desistiam das escolas, fechando-se turmas. O fato resultava na redução da possibilidade dos professores complementarem sua jornada no período noturno e reforçava a percepção de que era necessária uma administração escolar padronizada, em que a organização pedagógica da EJA se submetesse ao sistema burocrático para atribuição de aulas, e não o contrário.

Outro indicador levantado por essa gestão era que a duração do período de aulas nas EMEFs era excessiva para jovens e adultos trabalhadores que não conseguiriam frequentar as escolas por tantas horas. Indicavam-se como problemas a falta de flexibilidade de horário, a permanência de uma concepção compensatória da EJA, a falta de articulação entre escolarização e mundo do trabalho, a necessidade de considerar a experiência dos estudantes e outros espaços de formação como integrantes do conhecimento, a incipiência da interdisciplinaridade (SME, 2008), reiterando os mesmos problemas indicados em governos anteriores.

Essas questões seriam reforçadas pelo "feedback" dos professores e gestores escolares e se pautariam nas bases que levaram à constituição do Projeto CIEJA, impactando nas escolhas das soluções para a modalidade na cidade. 
Romy Schinzare esclarece que, como coordenadora pedagógica e supervisora de EJA na região de Campo Limpo, já conhecia o Projeto CIEJA desde o início de seu funcionamento e tinha uma avaliação bastante positiva sobre ele.

Eu acho o Projeto CIEJA um excelente projeto; tanto eu acho bom, que quando a
gente começou a se reunir... Eu digo "a gente", como Diretora, não trabalha nunca
sozinha, e não é demagogia, não trabalha mesmo, a gente trabalha com equipe e
com assessoria e com as redes, as Ongs e com os sindicatos, e com todo esse outro
universo que acopla, onde está inserido... E o CIEJA era um projeto que eu já
conhecia no Campo Limpo; eu conheci o surgimento do CIEJA muito assim na fase
de elaboração, quando ele surgiu; porque uma professora da escola que eu era CP,
que eu era Coordenadora, que foi convidada para ajudar a escrever esse projeto e
ela saiu, a Êda. Então, eu já conhecia o projeto. Só que quando eu cheguei na SME,
eu fui ler esse projeto com mais calma, e tem um outro lado que é a sistematização.
Eu sempre achei que era um projeto bom, a Êda já me falava dele e depois quando li,
eu cheguei a essa conclusão. (Romy Schinzare, março de 2013)

A fala de Romy Schinzare deixa transparecer que sua percepção positiva sobre o Projeto CIEJA refletia a ideia de diferentes atores: aquelas atuantes nas ONGs, sindicatos, entre outros, o que influiria nas decisões políticas em relação à EJA.

No entanto, as condições problemáticas relacionadas ao CIEJA, especificamente, remontam à situação do Projeto no final da gestão de Marta Suplicy. Desde o início do funcionamento dos Centros, o Conselho Municipal de Educação da cidade emitiria pareceres regulando e autorizando a continuidade do Projeto CIEJA. O Parecer CME n ${ }^{\circ}$ 34/04 recomendava a elaboração de uma nova versão do Projeto CIEJA, agregando as experiências de sua implementação. Já o Parecer 10/02, que autorizava o funcionamento Projeto CIEJA, recomendava "que estude a possibilidade de criação de módulo específico de qualificação em Informática, para permitir acesso autônomo de interessados, além de estar presente nos itinerários deste projeto e nos dos demais cursos a serem propostos". (PMSP/CME, 2002).

Os pareceres indicavam, ainda, a necessária adequação dos CIEJAs em termos de carga horária, cumprimento dos 200 dias letivos e formulação do Novo Projeto. O cumprimento dos dias letivos dependia da validação das atividades complementares e extraescolares pelo CME. Elas ocorriam, muitas vezes, às sextas-feiras, quando determinado período era destinado à reunião dos professores para planejamento e sistematização das experiências e as aulas para algumas turmas eram oferecidas em horários diferentes daqueles que frequentavam de segunda à quinta-feira, antes ou após as reuniões ou, ainda, em atividades diferenciadas durante a semana.

A consideração de que os dias letivos deveriam coincidir com o horário fixo de todas as 
turmas faria com que, ao longo dos anos, o período das reuniões coletivas fosse diminuído nas sextas-feiras. Verifica-se também que em muitos Centros essa demanda significou a fragmentação da reunião coletiva em pequenos horários nos outros dias da semana, já não sendo possível reunir toda a equipe docente.

Alguns Centros optaram por fechar as turmas do primeiro período vespertino (13:00 às 15:15), em que a demanda dos estudantes era menor, o que propiciaria o encontro dos docentes no mesmo horário. Os CIEJAs Butantã e Campo Limpo mantiveram os horários de sexta-feira em período menor, porém garantindo a presença de todos os docentes.

Nota-se, novamente, que embora os CIEJAs buscassem constituir um modelo educativo específico para jovens e adultos, constantemente eram avaliados sob o modelo escolar da rede. A organização das aulas, dos módulos de aprendizagem, era avaliada segundo o cumprimento do ano letivo nas escolas para crianças. A atribuição de aulas e o horário de formação docente continuavam sendo comparados aos das EMEFs. Verificamos, então, uma constante tensão entre a inovação pedagógica pretendida e a administração burocrática do sistema de ensino.

Nos dois últimos anos dessa gestão, a EJA também passou por uma reorganização, autorizada pelo Parecer CME nº 96/07, em que define suas diretrizes. A Reorganização da EJA trazia como alternativas características do modelo dos CIEJAs.Como possíveis soluções aos problemas apontados, mantinha-se a proposta de democratização do acesso à EJA, que seria buscada através do pleno atendimento da demanda nas escolas e oferta de educação profissional em pólos regionais. Desse modo, a Reorganização da EJA na gestão Kassab (2006-2009):

Contém um sentido geral de flexibilidade, tanto de tempo e de espaço, quanto de estrutura curricular, tendo sido considerados os pontos críticos assinalados, o que conduz às seguintes linhas de ação: - Rompimento da simetria da EJA com o ensino regular para crianças e adolescentes, de modo a permitir percursos individualizados e conteúdos significativos para os jovens e adultos. - Adoção de organização curricular flexível, mantendo-se a desejada unidade da Rede, não baseada na uniformidade, mas, sim, na duração do curso e em padrão mínimo, constituído por expectativas de aprendizagem comuns. (SME-DOT, 2008, p.13)

Mantendo quatro frentes de atendimento aos jovens e adultos na cidade - EJA nas unidades escolares (EMEFs), CIEJAs, MOVA e CMTCs - observa-se que a "unidade" almejada para a modalidade pretenderia a aproximação entre as escolas de EJA e CIEJAs.

Para promover a flexibilidade do tempo, em 2008, os quatro anos de escolarização 
passariam a ser desenvolvidas em etapas com um ano de duração, cada uma com 200 dias letivos, 500 horas anuais, sendo 450 obrigatórias e 50 de intervalos: alfabetização; básica (pósalfabetização); intermediária e final. A mudança nos tempos nos cursos, que deixavam de ser semestrais para serem anuais, condensando dois termos em um mesmo ciclo ou módulo, decorria de uma percepção sobre a especificidade da EJA em relação ao Ensino Fundamental e também sobre os entraves burocráticos para o desenvolvimento dos cursos semestrais.

A Reorganização da EJA empreendida trouxe como solução que os cursos exigissem a presença obrigatória em duas horas e meia de aula, sendo o restante destinado a projetos específicos (SME-DOT, 2008).

O currículo foi, então, dividido em Eixo Central, que correspondia às disciplinas com carga horária obrigatória e Eixo variável, em que se desenvolveriam projetos e Orientações de Estudos $^{37}$ aos alunos. Também no Eixo variável é que seria possível criar parcerias e convênios para articulação do currículo com a qualificação profissional. A proposta dessa integração curricular entre o Ensino Básico e a Qualificação Profissional também é apresentada no documento de Reorganização da EJA tomando-se o exemplo do convênio realizado pelo Projeto CIEJA com o Senac - SP, mas não chegou a se efetivar. O convênio também terminara no ano anterior, indicando um descompasso entre as diretrizes no plano dos discursos e sua aplicação prática.

As "Expectativas de Aprendizagem" para EJA, assim como para demais modalidades da cidade, guiariam o trabalhado das EMEFs e CIEJAs a partir de diretrizes comuns. Formuladas para cada disciplina do Ensino Fundamental, desenhavam o plano de curso, encaminhavam formas de avaliação do aluno e do trabalho docente. (SME/DOT, 2008).

Esse desenho para EJA na cidade orientava que a "unidade" das iniciativas voltadas para a modalidade seguiriam as características do Projeto CIEJA, principalmente no que tange à organização de orientações de estudos e projetos.

A concepção de EJA desta proposta aproveita a experiência inovadora dos CIEJAs, incorporando aspectos, tais como, anualidade de etapas, menor tempo diário de aula, orientação de estudos, oferta de Qualificação Profissional Inicial, valorização das experiências dos alunos, trabalho coletivo dos professores. (SME /DOT, 2008, p.23)

A fala da ex-diretora de DOT EJA ratifica essa ideia:

O CIEJA foi a inspiração da reorganização, sem dúvida. Foi que deu o próprio foco.

\footnotetext{
${ }^{37}$ Também chamadas de Oficinas de Estudos, as Orientações de Estudos são atendimentos individuais ou em pequenos grupos para tirar dúvidas e orientar projetos.
} 
E tem que ser. Eu penso, né, que não adianta você ter um projeto, se não for para ele inspirar uma ampliação para uma rede maior.. É como se fosse um projeto-piloto de EJA. E eu tive, precisava aproveitar essa experiência para que toda rede, para que tivesse uma harmonia nessa rede, porque não precisa ter CIEJA, EJA, EJA Modular, EJA não modular, isso é uma loucura, né?(Romy Schinzare, março de 2013)

O relato de Schinzare também reforça a ideia, de certo modo recorrente, de que o Projeto CIEJA deveria alcançar as EMEFs. No entanto, se nas gestões petistas pensava-se em anexá-los às escolas, na gestão de Kassab idealizava-se que as escolas se aproximassem de suas características.

É relevante notar, então, que percebido e estruturado enquanto projeto, os CIEJAs "nasceram para acabar", como narrou Roseli Pereira. Isso nos revela que os diferentes governos, antes de pensarem no modelo de escolarização específico para jovens e adultos, buscavam experimentar um modelo de EJA que pudesse ser enquadrado na organização escolar tradicional.

Ainda em 2006, os Coordenadores Gerais (gestores) dos CIEJAs foram chamados a participar, num primeiro momento, de algumas reuniões junto à Diretoria de Orientações Técnicas de EJA (DOT/EJA) para reorientação da EJA na cidade, mas em meados desse ano deixaram de ser convocados para elas.

Compreendendo o Projeto CIEJA como “projeto-piloto", a aplicação de suas características na rede poderia conduzir à sua desconstituição. Essa era a percepção da Professora Célia Borges e da Orientadora Pedagógica Roseli Pereira, que participaram daquelas reuniões.

Nessa parte burocrática eu não sou muito boa, mas eu acho que a ideia era fechar o CIEJA. Mais para frente, com certeza, ele seria mesmo fechado. Mas nessa época, eu acho que já tinha essa ideia. Assim, a gente vai deixar a EJA na escola mais parecido com o que vai no CIEJA e aos poucos teria uma... o que eles chamavam de... ai eu já não sei se é incorporação. Como é que era o nome? CIEJA ia ficar meio que pendurado dentro na escola. (Célia Borges, outubro de 2012)

Se a EJA atender, para que CIEJA? Então, qual era a proposta inicial? Quando a pessoa descobriu que estava tendo essa ideia? Acabava a questão do CIEJA, $e$ ficavam as classes vinculadas a uma EMEF. No nosso caso, a gente ficaria vinculado ao Marechal (EMEF). E aí o que acontecia? Não tinha Coordenação Geral, não tinha mais Orientação Pedagógica, não tinha nada, mas as salas que estariam funcionando aqui, ficariam sob a orientação da Diretora da Escola, os professores seriam de lá, tudo ficaria ali. (Roseli Pereira, novembro de 2012)

Os pareceres do CME indicavam a necessária adequação dos CIEJAs ao projeto original e demandava a melhoria dos índices de aprovados e concluintes. No ano de 2007, o relatório anual de desenvolvimento do Projeto CIEJA, elaborado pelas unidades e sintetizado 
pelos técnicos da DOT, não foi apresentado ao CME. A DOT-EJA justificou que esse fato era devido à elaboração da Reorganização da EJA na cidade, o que reforçaria a ideia de que o CIEJA seria fechado.

Na oportunidade [Parecer CME $n^{\circ} 81 / 06$ ], este Colegiado assim se manifestou: "Em caso de as novas propostas para a educação de jovens e adultos não mais responderem às finalidades educacionais contidas no Parecer CME $n^{\circ} 10 / 02$, não há que se falar em flexibilização na organização curricular do Projeto CIEJA, mas de um novo Projeto para a educação de jovens e adultos (PARECER CME 96/07).

A percepção de diferentes atores sobre o encerramento do Projeto CIEJA após sua possível integração na rede teria sido confirmada para Êda Luiz por um profissional da própria SME. A notícia gerou uma mobilização das equipes técnicas e estudantes dos Centros contra essa possibilidade. Marcadamente, em 2007 houve uma manifestação de estudantes do CIEJA Campo Limpo diante do Secretário Municipal de Educação, em que reclamavam a manutenção do Projeto tal como funcionava. Após essa manifestação, o então Secretário Municipal de Educação Alexandre Schneider lançaria à Êda Luiz o desafio de que os profissionais do CIEJA redigissem o Novo Projeto:

Então, foi dia 27 de agosto de 2007, quando nós fomos avisadas que o CIEJA
poderia terminar aquele ano, que ele não seria mais aprovado para o ano de 2008,
porque tinha muita diferença em termo quantitativo, de evasão, de manutenção. Não
perceberam o que estava gerando isso, recebemos uma quantidade enorme de
inclusão, e você não pode correr com essa inclusão, você tem que repensar o ritmo,
um número crescente de adolescentes... Muitas questões. E eu fiquei sabendo que nós
não teríamos o CIEJA, aí fiquei sabendo também da visita do Secretário e do
Prefeito aqui na nossa região e fomos nós conversar com eles. E eles vieram, nos
desafiaram... Na época, quando o Secretário conheceu o projeto, eu acho que foi
interessante e antes de assinar qualquer coisa, ele teve a oportunidade de conhecer.
Então, desafiou quem estava aqui, a escrever o CIEJA; o novo projeto que atendesse
todas as questões que foram levantadas pelo Conselho Municipal da Educação. (...)
Nós tínhamos, na época, mais ou menos, de 1.400 a 1.500 alunos. E quando ele nos
desafiou... Vamos embora! Aí, eu acho que a grande tacada que nós demos, foi todos
nós nos reunirmos e fazermos uma escrita coletiva.

Observamos que as equipes dos CIEJAs se articulam contra o encerramento da proposta e atuam como grupo de pressão sobre as decisões de SME, a partir da mobilização dos estudantes e população.

Nota-se que o protesto do CIEJA Campo Limpo, direcionado ao Secretário Municipal de Educação, introduz na discussão desse problema um agente político que, de outra forma, poderia decidir baseado nas decisões de seus assessores e técnicos. Sua visita ao CIEJA Campo Limpo também o aproxima da realidade dos Centros e da EJA.

O Secretário lança o desafio de escrever o novo Projeto CIEJA aos próprios Centros, 
de um lado desobrigando os técnicos de SME de executar a "tarefa" do CME, de outro propiciando que os CIEJAs tivessem diálogo mais direto com sua realidade e com a própria Secretaria.

A atuação dos educadores dos CIEJAs e a mobilização dos alunos para influenciar as políticas, garantir o funcionamento dos Centros ou demandar a ampliação do atendimento ao Ensino Médio se desenvolveria durante as gestões de Kassab na cidade (2006-2011).

Embora o art. 211 da Constituição federal estabeleça que é função da rede estadual “assumir os encargos pela manutenção e expansão do Ensino Médio público, visando a sua progressiva universalização", observamos na última década uma política de crescente fechamento das turmas de EJA no Estado de São Paulo (VIEIRA, 2011). Além disso, a falta de propostas para EJA aproximadas do modelo dos CIEJAs conduz os estudantes a requisitarem do governo municipal a oferta desse nível de ensino nos Centros que frequentam. A flexibilidade de horários, as alternativas de frequência e reposição de aulas são vistas, por esses estudantes, como essenciais para dar continuidade aos estudos.

Na rede municipal, a proposta de "Reorganização da EJA", em 2008, contribuiria para respaldar o desenho do Novo Projeto CIEJA, uma vez que compartilhavam princípios e formas de organização. Nesse sentido, também eram desenhados os Cadernos de Orientações Didáticas para Educação de Jovens e Adultos (publicados em 2010), por meio de um GT com professores de EJA na rede, assessorado, entre outros especialistas, por Luis Percival Britto, cujas concepções de EJA afastavam-se daquelas compensatórias e se aproximavam do paradigma da Educação Popular e de educação ao longo da vida já presentes no Projeto CIEJA.

\begin{abstract}
A educação de adultos não deve ser pensada como um processo de recuperação de algo que tenha sido perdido ou não aprendido no momento adequado. Tampouco deve seguir os mesmos critérios e referenciais da educação regular de crianças e adolescentes. $\mathrm{O}$ adulto não volta para a escola para aprender o que deveria ter aprendido quando criança e não aprendeu. Ele busca a escola para aprender habilidades necessárias para ele no momento atual. Sempre a partir daquilo que ele, enquanto sujeito histórico, sabe e é. (BRITTO, 2003, p. 204)
\end{abstract}

Notamos a Reorganização da EJA (2008) fomentaria a atuação dos sindicatos dos professores $^{38}$. Nas EMEFs ela traria dificuldades relacionadas à atribuição de aulas para os docentes e articulação do currículo transdisciplinar.

\footnotetext{
${ }^{38}$ Selecionamos os discursos do Sindicato dos Profissionais da Educação do Ensino Municipal (SINPEEM) por ser aquele com maior representatividade dos servidores da educação no município de São Paulo.
} 


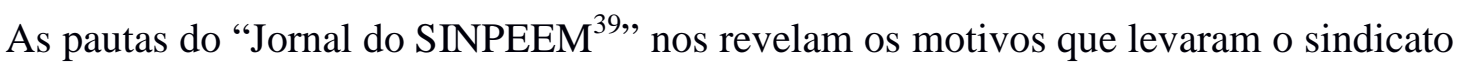
dos profissionais da educação da cidade de São Paulo a se posicionar contra a mudança da Reorganização da EJA proposta por SME. A diminuição do período de aulas obrigatórias nas EMEFs fez com que na muitos professores que complementavam a carga horária na EJA perdessem as aulas nessa modalidade. Eles ficaram obrigados a reduzir a jornada de trabalho, da Jornada Especial Integral de Formação (Jeif) para Jornada Básica Docente (JBD) ${ }^{40}$, o que impactava em sua pontuação na carreira e remuneração. Apontava-se, ainda, que os horários destinados às Orientações de Estudos eram pouco aproveitados pelos estudantes, já que eram de frequência optativa. Destacamos, nesse ponto, que cada unidade educacional poderia desenvolver as Orientações de Estudos de acordo com projetos próprios, bem como nos CIEJAs se articulam, nesse período, a reposição de aulas, plantão de dúvidas e projetos diversos. No entanto, segundo os discursos do "Jornal do Sinpeem" esses períodos alternativos e optativos de aula assumiram caráter precário nas unidades.

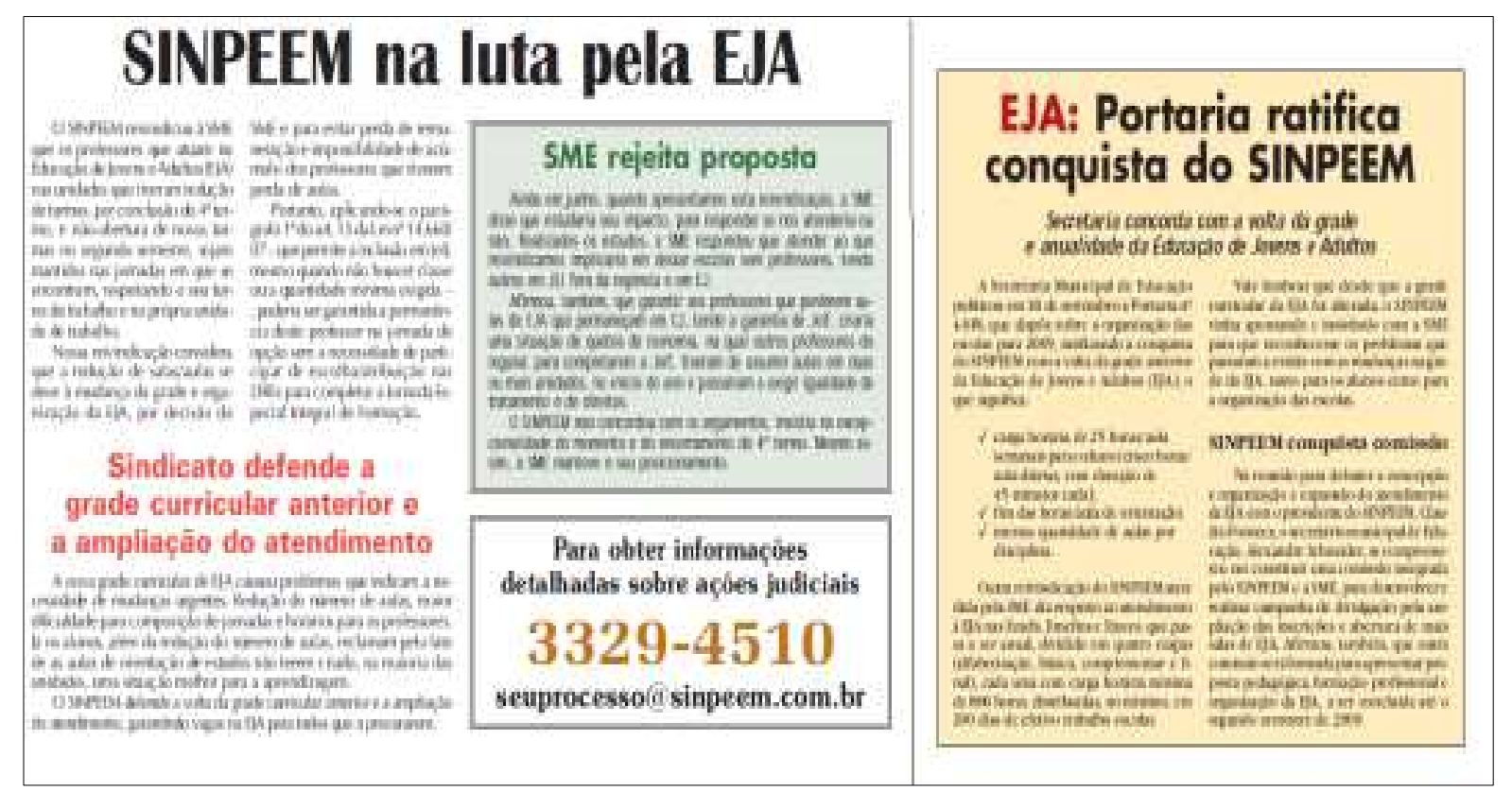

Figura 3- Jornal do SINPEEM ${ }^{41}$, edições de setembro e de dezembro de 2008

Durante o ano de 2008, esses conflitos marcaram o diálogo entre o sindicato e SME,

\footnotetext{
${ }^{39}$ Jornal do Sinpeem n ${ }^{\circ} 103$ e n ${ }^{\circ} 104$ de 2008.

${ }^{40}$ A Jornada Especial Integral de Formação (Jeif) corresponde a 40 horas/aula semanais, sendo 25 horas/aula de regência, 11 cumpridas obrigatoriamente na escola e 04 em local de livre escolha. Apenas podem optar por essa jornada os docentes que têm 25 horas/aulas de regência. A participação dos professores nas formações da Jeif confere-lhes pontuação na carreira e remuneração pelos horários de formação no trabalho, sendo mais vantajosa que a Jornada Básica Docente (JBD) que integra.

${ }^{41}$ Os dois trechos estão reproduzidas, também, nos anexos.
} 
que manteve a proposta de "Reorganização da EJA" intacta até novembro desse mesmo ano eleitoral. É relevante notar que o presidente do SINPEEM, Claudio Fonseca, foi eleito como vereador pelo Partido Popular Socialista (PPS) no final de 2008. Seu partido negociava compor a bancada de apoio ao governo de Gilberto Kassab (DEM) em 2009, ao mesmo tempo em que o vereador pressionava aquele mesmo governo a recuar na proposta para EJA. De fato, logo no período de negociações entre os partidos do governo e aqueles que iriam compor a base aliada na Câmera, a SME retrocedeu em suas decisões sobre a "Reorganização da EJA", em relação carga horária das aulas, organização de projetos nas Orientações de Estudos, atribuição de aulas ao professor.

Romy Schinzare avalia que a pressão de diferentes atores impediu que se avaliasse adequadamente aquela experiência antes de a SME voltar atrás em relação às mudanças empreendidas, destacando a atuação dos sindicatos de professores. Marcamos que desde o início de sua entrevista, cuja pauta "CIEJAs" era de seu conhecimento, ressaltou que o Projeto CIEJA tinha um modelo próprio de organização que enfrentaria entraves na organização burocrática das EMEFs.

Eu acho que é uma alternativa para a EJA, não se aplica $100 \%$, porque a rede tem outro desenho, são professores concursados naquela área, com aquela carga horária, com aquela jornada de trabalho, e o CIEJA tem uma liberdade maior nesse sentido; então, você não consegue pegar um projeto como o CIEJA, e do jeito que ele está transportar para a rede inteira; pelo menos, não se consegue com o desenho que se tem de rede, a não ser que a própria Secretaria mudasse com esse desenho de professores de Educação de Jovens e Adultos. Teria que rever toda essa parte, entendeu? Do jeito que está fica difícil, é como se um quadrado não coubesse dentro do outro, entendeu? Por isso que quando reorganizamos a EJA, eu peguei essa experiência junto com o Grupo de CIEJA, junto com os representantes das DREs, e a gente discutiu a partir daí, como fazer. Teria só um pequeno ajuste disso para a rede, não só porque o CIEJA era bom projeto, quer dizer, por que era um bom projeto para a EJA? Porque ele atendia algumas demandas da Educação de Jovens e Adultos, desse universo em que está inserido esse aluno, de que a EJA às vezes não dá conta, né? Então, por isso eu achava um bom projeto, continuo achando. (Romy Schinzare, março de 2013)

O desenho da atribuição de aulas e perfil dos educadores da EJA teriam, então, contribuído para que o modelo dos CIEJAs não "coubesse" nas EMEFs. Quando se refere à "liberdade" na organização do trabalho docente, inferimos que as atribuições de aulas e designações de professores para trabalho exclusivo nos Centros facilitariam o desenvolvimento dessa proposta.

O relato de Schinzare também revela sua percepção positiva do Projeto CIEJA pautava-se na avaliação de que ele atendia as necessidades dos jovens e adultos, portanto, 
deveria estender-se a toda rede, entendimento que se afastava das prioridades do sindicato em atender as demandas de professores pela manutenção do período e atribuição de aulas nas EMEFs.

Com os retrocessos em relação às propostas de Reorganização da EJA, no final da primeira gestão Kassab, a modalidade continuaria a ser ofertada em quatro modalidades diferentes: EJA, MOVA, CIEJA e CMTC, que compartilhariam, em tese, os pressupostos curriculares e pedagógicos expressos nas "Orientações Curriculares para EJA”.

A escrita coletiva do Novo Projeto CIEJA seria estendida de 2007 até 2009. Verificamos mudanças em relação à organização curricular e carga horária em cumprimento às demandas do Conselho Municipal de Educação. Para tanto, os Itinerários Formativos também seriam colocados fora dos horários de aula e da carga horária obrigatória do aluno, passando a ter frequência opcional.

Verificamos que o novo projeto possui, até determinado ponto, a mesma estrutura de redação do documento do projeto original, no entanto, há maior detalhamento sobre as matrizes curriculares e maior pluralidade entre concepções metodológicas. Acrescentam-se, ainda, determinações quanto ao seu quadro de pessoal, matrícula, classificação e reclassificação de alunos. A fala da Coordenadora Geral do CIEJA Campo Limpo Êda Luiz ilumina o processo e os sentidos da redação coletiva do Novo Projeto CIEJA.

Íamos a cada CIEJA conhecer a comunidade, professor, horário e tudo. Discutindo por que fizemos o CIEJA? O quê que a gente poderia criar que seria legal para a reorganização dele? Então, o Projeto foi escrito da base mesmo. E foi muito interessante, porque, na época, 12 CIEJAs imediatamente foram envolvidos, só tivemos um que não quis entrar, porque ficou preocupado com grade e tudo, que nós estaríamos indo para outro Governo, qualquer coisa assim... E nós falamos: Olha, nós vamos escrever! Levamos um ano, realmente foram dois anos, mas em um ano e pouco, nós percorremos todos os CIEJAs, eu conheço todos. Eu levava todo mundo, teve choro, teve alegria, teve brigas, mas foi um lindo trabalho. Eu acho que é o grande diferencial desse projeto é ser visto por nós, que nós podemos servir, dar oportunidade de escrever aquilo por quem praticava, quem sabia, quem estava lá na base todo dia, né, com os alunos, com a comunidade. E aí saiu, nós entregamos para o Secretário, e saiu, pelo Conselho Municipal de Educação, o Novo CIEJA, com muito poucas mudanças, mas de uma maneira mais clara, porque... não teve antes. Nós estávamos nos organizando na saída de um parceiro para o itinerário formativo. Até a gente ser desafiado a escrever, cada um seguiu, porque tinha que se organizar. Então cada um seguiu meio do seu jeito. Assim, eu acho que foi a melhor época, porque cada um atendeu a sua comunidade realmente, porque cada um se organizou para atender seus alunos, né, todos os atores que apareceram naquele momento. Mas aí nós precisávamos de uma linha, né, pelo menos um fio condutor para ser um projeto, e aí foi aprovado com o compromisso do Secretário de tornar lei, porque tornando lei, nós não dependemos mais das autoridades fazerem concessões: Ah, eu quero, eu não quero. ( $\hat{E} d a$ Luiz, dezembro de 2012) 
O relato de Êda Luiz deixa clara a necessidade que gestores e professores tinham de obter maior institucionalização do Projeto CIEJA, de modo a garantir sua continuidade independentemente do governo que assumisse a cidade. Os CIEJAs encontravam o desafio de dar corpo à pluralidade de suas práticas em um mesmo projeto e de responder às demandas do CME. As especificidades de cada centro desenvolveram-se durante sua implementação, reafirmando a diversidade entre eles desde sua origem enquanto CEMES.

O desafio proposto pelo Secretário da Educação propiciaria que, em busca de garantir sua continuidade entre as iniciativas de EJA na cidade, fossem encontradas as "linhas condutoras" que teceriam o Projeto, a partir daqueles que o vivenciavam com os estudantes. 


\section{OS SUJEITOS E O MODELO DE ORGANIZAÇÃO ESCOLAR DOS CIEJAS}

As escolas são equipamentos públicos, mas são constituída sobretudo pelas pessoas que nelas convivem, concedendo-lhes determinado modo de funcionar, certo "clima" e identidade. No capítulo anterior, observamos que entre as justificativas que sustentaram a continuidade do Projeto CIEJA em diferentes governos está sua adequação às condições e necessidades estudantis, conforme a LDB 9394/96.

Neste capítulo, lançamos um olhar ao perfil dos educandos que frequentaram os Centros ao longo dos anos e ao modelo de organização escolar, constituído para atendê-la.

\subsection{O Perfil dos Educandos}

Considerar a diversidade dos sujeitos da EJA, seja em relação à sua origem, faixa etária, seja em relação à experiência social de mulheres e homens, é essencial para definição de políticas que alcancem a todos.

Essa diversidade também esteve presente na trajetória dos CIEJAs e para abordá-la, consultamos os dados $^{42}$ sobre os estudantes de Suplência I de 1989; a pesquisa ${ }^{43}$ sobre o perfil dos estudantes nos antigos CEMES em 2002 e os dados de matrícula nos CIEJAs em 2012. Eles nos aproximam das mudanças e permanências entre as características dos jovens, adultos e idosos da EJA em São Paulo, que teriam norteado a configuração do Projeto CIEJA.

De acordo com o Relatório de Pesquisa Caracterização dos alunos dos CEMES em 2002, ano que antecede sua transição para CIEJAs, 28\% dos estudantes tinham nascido no município de São Paulo e 2,9\% em outros municípios da Região Metropolitana, cerca de 70\% vinham de Centros menores, dos quais aproximadamente 50\% eram do Norte e do Nordeste, em especial da Bahia e de Pernambuco. (DOT-EJA/SENAC-SP, 2002, p. 6).

\footnotetext{
${ }^{42}$ Os dados foram coletados com os educandos da Suplência I dos NAEs 1 e 4, correspondentes, respectivamente, à região de Vila Mariana, Sé, Pinheiros, Ipiranga e à região de Perus, Pirituba, Jaraguá, Lapa e Butantã em 1989. Estão apresentados no Caderno 3 "Alfabetização de Adultos: um desafio pedagógico, político, social" (SME, DOT-EDA, 1992).

${ }^{43}$ Pesquisa realizada pela DOT-EJA em parceria com o SENAC-SP durante a gestão de Marta Suplicy (20012005).
} 
O traço da migração entre a maioria dos jovens e adultos dos CEMES reiterava o dos alunos de Suplência I em $1989^{44}$, em que 66,67\% eram do Nordeste, 15,5\% de outras regiões, restando apenas 22,5\% estudantes cuja origem era o Sudeste (SME/ DOT-EDA, 1992, p.10). As regiões Norte e Nordeste do país, de onde veio grande parte desses estudantes, ainda apresentavam os maiores índices de analfabetismo do Brasil nos anos de 2010 (IBGE, 2010), refletindo na baixa escolaridade dos migrantes na cidade de São Paulo.

A origem desses jovens e adultos nos revela muito mais que a desigualdade entre as oportunidades educacionais e econômicas no país, que persistem há mais de uma década. Os alunos migrantes enfrentam também a necessária adaptação de seus costumes e vivências, frequentemente em comunidades pequenas em que a cultura oral e popular predomina, para sobreviverem na metrópole mergulhada na cultura letrada. (FROCHTENGARTEN, 2006).

O tempo de escolaridade dos jovens e adultos antes de frequentarem os cursos de EJA também demonstra a persistência das condições precárias de acesso e permanência nas escolas e a repetida negação do direito à educação a essa parcela da população.

Dos estudantes que frequentaram a escola antes de chegarem aos CEMES em 2002, $36 \%$ havia interrompido os estudos havia mais de onze anos e 30\% interromperam estudos havia cinco anos ou menos. As dificuldades de permanência dos estudantes na escola continuam a ser verificadas mais atualmente, fazendo com que diferentes gerações convivam nos bancos escolares da EJA. Esses fatores ratificam a importância do ensino presencial, em que o educador seja um mediador entre o conhecimento científico e a vivência dos educandos nos CIEJAs.

As tabelas seguintes tratam da modalidade EJA em 1989 e 2002, apontam também a importância da relação entre gêneros para explicar a falta ou dificuldade de acesso e permanência de jovens, adultos e idosos na escola; refletindo os papéis sociais que tradicionalmente homens e mulheres desempenham.

Tabela 5 - Porcentagem de estudantes de EJA segundo gênero e faixa etária - 1989

\begin{tabular}{lll}
\hline Faixa etária & Homem(\%) & Mulher $(\%)$ \\
\hline Até 20 anos & 19,2 & 18,9 \\
De 20 a 30 anos & 22,6 & 17,1 \\
Acima de 30 anos & 6,1 & 15,9 \\
\hline Tabela adaptada do Relato de Práticas Pedagógicas, SME/ DOT-EDA, 1992.
\end{tabular}

\footnotetext{
${ }^{44}$ Pesquisa realizada com os estudantes das NAEs 1 e 4, publicada documento "Reorientação Curricular do Ensino Noturno" (SME, 1992).
} 
Tabela 6 - estudantes dos CEMES segundo gênero e faixa etária - 2002

\begin{tabular}{ccccccc}
\hline $\begin{array}{c}\text { Faixa } \\
\text { etária }\end{array}$ & \multicolumn{2}{c}{ Homem } & \multicolumn{2}{c}{ Mulher } & \multicolumn{2}{c}{ Total } \\
& $\mathrm{n}$ & $\%$ & $\mathrm{n}$ & $\%$ & $\mathrm{n}$ & $\%$ \\
\hline Até 17 & 240 & 10,4 & 185 & 6,2 & 425 & 8 \\
18 a 25 & 672 & 29 & 614 & 20,7 & 1286 & 24,3 \\
26 a 30 & 430 & 18,6 & 381 & 12,8 & 811 & 15,4 \\
31 a 35 & 337 & 14,5 & 428 & 14,4 & 765 & 14,5 \\
36 a 45 & 404 & 17,5 & 657 & 22,1 & 1061 & 20,1 \\
46 a 55 & 157 & 6,8 & 554 & 15 & 602 & 11,4 \\
56 e mais & 72 & 3,1 & 257 & 8,7 & 329 & 6,2 \\
Sem & 0 & 0,1 & 0 & 0 & 2 & 0,1 \\
resposta & & & & & & \\
total & 2314 & 43,8 & 2957 & 56,2 & 5281 & 100 \\
\hline Fonte: Relatório de Pesquisa Caracterização dos alunos. DOT-EJA/SENAC-SP, 2002.
\end{tabular}

Atentemos para que, em relação à faixa etária, as tabelas anteriores utilizam recortes diversos, cujas escolhas não foram explicitadas. A delimitação de uma faixa de idade, como sabemos, engloba determinada visão sobre os grupos. O IBGE, por exemplo, delimita três $\operatorname{agrupamentos}^{45}$ que, diante do aumento de expectativa de vida da população e da complexidade em se delimitar os ciclos de vida na sociedade pós-moderna (POCHMANN, 2005), são insuficientes para refletirmos sobre os dados anteriores. Segundo esses agrupamentos, a maioria dos estudantes dos CEMES em 2002 seria de adultos (de 19 a 59 anos).

Tratando-se de um intervalo temporal bastante grande e, por consequência, que abrange necessidades muito variadas entre os sujeitos, apenas a consideração do critério utilizado pelo IBGE, nos conduziria a desviar a atenção sobre um traço relevante: a concentração do número de adultos jovens entre as idades de 18 a 45 anos, que coincide com os tempos de buscar trabalho ou melhores oportunidades profissionais. Segundo o Estatuto da Juventude, Lei 12.852/2013, são consideradas jovens as pessoas entre 15 e 29 anos.

As pesquisas e diretórios de matrículas dos estudantes de EJA utilizam indicadores e critérios não esclarecidos e distintos. $\mathrm{O}$ uso de diferentes recortes etários nas pesquisas sobre o perfil dos estudantes da EJA e do CEMES dificulta a comparação entre os dados e uma análise mais aprofundada sobre as permanências e mudanças nos perfis ao longo do tempo. No

\footnotetext{
45 Segundo o IBGE, as pessoas de 12 a 18 anos são consideradas adolescentes, de acordo com o Estatuto da Criança e do Adolescente (Lei $n^{\circ} 8.069$ de 13 de julho de 1990). As pessoas com 60 anos ou mais são consideradas idosas, conforme o Estatuto do Idoso (Lei $\mathrm{n}^{\mathrm{o}} 10.741$ de 01 de outubro de 2003). Já o grupo de pessoas na, faixa de idade intermediária, de 19 a 59 anos, é considerado como de pessoas adultas.
} 
entanto, os dados nos permitem notar o decréscimo no número de mulheres que frequentam a EJA após os 20 anos em 1989 e que freqüentavam os CEMES entre 26 e 35 anos em 2002. Percebe-se também maior o número de mulheres entre 36 e 45 anos nos CEMES neste período.

$\mathrm{O}$ afastamento e retorno das mulheres às escolas em determinadas faixas etárias pode ser explicado devido à dificuldade de conciliarem a maternagem ${ }^{46}$ com a vida escolar. A gravidez na adolescência pode também explicar o fato de que as mulheres abandonem a escola ainda no Ensino Fundamental e retornem após determinada idade, em que os filhos já frequentam as escolas.

Essa indicação permeou a escolha das soluções para EJA em São Paulo que teriam impacto na idealização do CIEJA, conforme revelou a entrevista com Marisa Darezzo, diretora de DOT EJA entre 2001 e 2004:

O objetivo era atender as demandas, no período da manhã, da tarde, porque nós tínhamos muito essa leitura: A mãe que às vezes leva o filho para estudar no período da manhã, se tiver um projeto que tem condições, onde ela possa frequentar as aulas; com certeza, nós iríamos conseguir atender muitas mães, muitas senhoras nesse outro projeto. (Marisa Darezzo, dezembro de 2012)

O retorno das mulheres à escola, na modalidade de educação de jovens e adultos, pode refletir, ainda, a importância de concluir os estudos para acessar o mercado de trabalho, num cenário em que as mulheres ampliam sua participação. No entanto, estudos apontam que a presença das mulheres no mercado de trabalho ainda ratifica as divisões de gênero em ocupações tradicionalmente consideradas femininas, frequentemente com menores remunerações e grau de formalidade, sobretudo, nos serviços domésticos. (SEADE, 2010)

As tabelas 5 e 6 também apresentam a maioria de mulheres em relação aos homens nas escolas, acompanhando a distribuição da população por gênero nas diferentes épocas ${ }^{47}$, e uma mudança no número de homens em pouco mais de uma década: no final dos anos de 1980, sua presença nos CEMES diminuía consideravelmente após os 30 anos de idade; já em 2002, essa queda ocorre após os 45 anos.

Apesar de a escolaridade relacionar-se ao acesso a melhores condições de trabalho, os

\footnotetext{
${ }^{46}$ Utilizamos o termo "maternagem" para designar o cuidado com os filhos, que ainda recai predominantemente sobre as mulheres mães.

${ }^{47}$ O número de mulheres em 1991 era também superior ao número de homens no município, em todas as faixas etárias, 4.992.977 mulheres e 4.653.208 homens (IBGE, 1989). Ainda nos anos 2000, verificam-se mais mulheres residentes no município que homens, respectivamente, 5461574 e 4972 678. (IBGE, 2000)
} 
dados ainda confirmam a tendência nacional de que entre os jovens, a média de anos de estudo é menor para os homens que para mulheres (CARVALHO, 2003).

Além das relações entre gênero e escolarização, em que pesam a gravidez precoce e posição social das mulheres, o Relatório de Pesquisa de Caracterização dos alunos (2002) depreende desses dados que "as pessoas vão à escola quando jovens e, próximas aos 20 anos, se retiram, talvez em decorrência de compromissos familiares ou de trabalho ou mesmo por desinteresse, retornando à escola após os 30 anos de idade" (DOT-EJA/SENAC-SP, 2002, p.5). No entanto, são os jovens, de 18 a 25 anos, que representavam a maior concentração de estudantes (24,3\%) nos CEMES em 2002, integrando grande parcela das pessoas que buscavam uma alternativa para conclusão dos estudos naquela proposta de EJA na cidade.

Os dados sobre a idade dos estudantes acompanhavam também os índices de escolaridade daquele período, uma vez que as maiores taxas de analfabetismo estavam entre os adultos com mais de 30 anos e idosos (IBGE, 2003) e que "somente a metade do total da população juvenil estudava, sendo a maior parte fora da série escolar correspondente à faixa etária" (POCHMANN, 2005, p.386).

A concentração de jovens nos CIEJAs continuaria significativa na última década, refletindo a realidade constatada nas outras propostas de EJA na cidade de São Paulo e apontada em estudos que tratam da "juvenilização" dessa modalidade de ensino no cenário nacional (SPÓSITO, 2006; ABRAMOVAY; CASTRO; ESTEVES, 2007; CARRANO, 2007).

Tabela 7- Número de alunos por faixa etária nos CIEJAs em 2013

\begin{tabular}{|c|c|c|c|c|c|c|c|c|c|c|}
\hline \multirow{2}{*}{$\begin{array}{l}\text { Faixa } \\
\text { etária }\end{array}$} & \multicolumn{2}{|c|}{ MOD. I } & \multicolumn{2}{|c|}{ MOD. II } & \multicolumn{2}{|c|}{ MOD. III } & \multicolumn{2}{|c|}{ MOD. IV } & \multicolumn{2}{|c|}{ TOTAL } \\
\hline & $\mathbf{N}^{\circ}$ & $\%$ & $\mathbf{N}^{\circ}$ & $\%$ & $\mathbf{N}^{\circ}$ & $\%$ & $\mathbf{N}^{\circ}$ & $\%$ & $\mathbf{N}^{\circ}$ & $\%$ \\
\hline 15 & 2 & $0 \%$ & 6 & $0 \%$ & 16 & $0 \%$ & 9 & $0 \%$ & 33 & $0 \%$ \\
\hline 16 & 5 & $0 \%$ & 26 & $0 \%$ & 125 & $1 \%$ & 251 & $3 \%$ & 407 & $4 \%$ \\
\hline 17 & 15 & $0 \%$ & 41 & $0 \%$ & 168 & $2 \%$ & 415 & $4 \%$ & 639 & $7 \%$ \\
\hline 18 & 14 & $0 \%$ & 35 & $0 \%$ & 124 & $1 \%$ & 343 & $4 \%$ & 516 & $5 \%$ \\
\hline 19 & 17 & $0 \%$ & 39 & $0 \%$ & 98 & $1 \%$ & 237 & $2 \%$ & 391 & $4 \%$ \\
\hline 20 a 24 & 79 & $1 \%$ & 119 & $1 \%$ & 295 & $3 \%$ & 599 & $6 \%$ & 1092 & $11 \%$ \\
\hline 25 a 29 & 81 & $1 \%$ & 121 & $1 \%$ & 212 & $2 \%$ & 310 & $3 \%$ & 724 & $8 \%$ \\
\hline 30 a 34 & 103 & $1 \%$ & 189 & $2 \%$ & 320 & $3 \%$ & 397 & $4 \%$ & 1009 & $10 \%$ \\
\hline 35 a 39 & 165 & $2 \%$ & 237 & $2 \%$ & 366 & $4 \%$ & 435 & $5 \%$ & 1203 & $12 \%$ \\
\hline mais de 39 & 623 & $6 \%$ & 886 & $9 \%$ & 1010 & $10 \%$ & 1169 & $12 \%$ & 3688 & $38 \%$ \\
\hline total & 1104 & $11 \%$ & 1699 & $18 \%$ & 2734 & $28 \%$ & 4165 & $43 \%$ & 9702 & $100 \%$ \\
\hline
\end{tabular}

Fonte: PMSP. SME. CI. Sistema Escola On-Line e Sistema SIGPEC (RH). Data Base: 30/Março/2013 
Como mostram os dados anteriores, somando-se o número de educandos de 18 a 24 anos dos CIEJAS em 2013, chegamos a 20,6\% do total de matrículas. Ainda nesse ano, os adolescentes de15 até 17 anos são cerca de 11\%, enquanto eram 8\% em 2002.

Segundo Pesquisa Nacional sobre Perfil e Opinião dos Jovens Brasileiros 2013, 65\% dos jovens ingressam no mercado de trabalho antes dos 18 anos de idade. Entre os meninos, verifica-se que 40\% tiveram o primeiro emprego antes dos 15 anos (ABRAMO, 2013, p.50). A relação entre juventude e trabalho também demonstra desigualdades sociais, conforme Abramo, entre os jovens que trabalham:

Nos estratos mais altos de renda quase o total dos jovens estão ou estiveram em empregos formais, enquanto nos extratos mais baixos a informalidade é superior em $10 \%$ à formalidade no trabalho. Jovens de cor branca têm $30 \%$ mais chances de ter emprego formal do que os jovens negros. E de mesmo modo, vemos que homens jovens possuem $25 \%$ mais chances de ter uma ocupação formal do que as mulheres jovens. (ABRAMO, 2013, p. 52).

Além disso, apenas $16 \%$ dos jovens que trabalham, o fazem por meia jornada (correspondente a 24 horas semanais), enquanto quase a metade trabalha mais de 40 horas semanais. Resguardado o fato de que a pesquisa reflete trajetórias não lineares, aponta para a realidade de que o ingresso no mercado de trabalho na juventude pode dificultar a continuidade dos estudos.

O número de jovens que não completam a escolaridade também se relaciona ao denominado "fracasso escolar".

Isso é preocupante porque a grande maioria desses jovens analfabetos são pessoas que passaram pela escola, que tiveram uma trajetória escolar marcada pela repetência, pela evasão, que vão e voltam ao sistema de ensino e não conseguem se apropriar da ferramenta da leitura e escrita. Esse é um indicador muito forte de que a escola está fracassando perante um grupo grande de jovens e este grupo concentra uma maioria de pessoas do sexo masculino (CARVALHO, 2003, p.186).

A tabela anterior também nos traz à luz uma realidade bastante importante nos CIEJAs, a porcentagem de estudantes no módulo IV, correspondente às $8^{\mathrm{a}}$ e $9^{\mathrm{a}}$ séries do Ciclo II é de $42,9 \%$, bastante superior àquela dos estudantes de módulo I e II juntos (28,9\%), que correspondem a todo Ciclo I.

Também é no Módulo IV que se concentram a maior parte dos adolescentes matriculados, o que corrobora a hipótese levantada ainda em 2002 no Relatório de Pesquisa caracterização de alunos, de que eles procuravam a aceleração escolar. As unidades de CIEJA podem estar absorvendo, então, assim como as demais propostas para EJA na cidade, a demanda criada no interior da própria rede de ensino municipal ou no Ensino Fundamental de 
outras redes. O chamado "fracasso escolar" marca as trajetórias de estudantes jovens que possuem, muitas vezes, interesses e expectativas bastante diferentes dos adultos e idosos.

Se, por um lado, o encontro de diferentes gerações na EJA constrói espaços que podem ser enriquecedores, permitida a troca de conhecimentos de vida e visões de mundo, de outro esse diálogo pode ser desafiador para as unidades escolares, como apontou a entrevistada Êda Luiz, Coordenadora Geral do CIEJA Campo Limpo:

“Daí você tem uma pessoa dentro da sala da aula, com 60 anos, que viveu a
ditadura, mas eu tenho menino que fala: O que é isso? Sabe?! (...) Então, como é que
se pode fazer para isso ser harmonioso? É difícil, não é nada fácil. Então, eu acho
que a outra coisa que a gente também vai pensar muito é esse adolescente muito
jovem, que está vindo para uma escola, que acha que é oba-oba, assim no sentido:
Ah, duas horas e quinze de aula, eu não vou e posso repor.. Sabe?! Como é que vai a
importância do conhecimento, para eles, na vida deles, na comunidade deles. E
como é que você faz um tema ser interessante, de uma maneira que um conta a
história para que o outro também entenda, se faça uma troca legal?” (Êda Luiz,
dezembro de 2012)

As questões lançadas por Êda Luiz podem estar presentes no cotidiano das demais unidades de CIEJA e EJA na cidade. Elas remontam à difícil e tão necessária tarefa de articular a convivência harmônica e o currículo escolar significativo para sujeitos da EJA tão diversos.

Os jovens, mesmo aqueles das periferias onde cidade não rima com cidadania, são
mais plurais do que aquilo que a instituição escolar deseja receber. A escola espera
alunos e o que chega são sujeitos com múltiplas trajetórias e experiências de vivência
do mundo. São jovens que, em sua maioria, estão aprisionados no espaço e no tempo
- presos em seus bairros e incapacitados para produzirem projetos de futuro. Sujeitos
que, por diferentes razões, têm pouca experiência de circulação pela cidade e se
beneficiam pouco ou quase nada das poucas atividades e redes culturais públicas
ofertadas em espaços centrais e mercantilizados das cidades. Jovens que vivem em
bairros violentados, onde a violência é a chave organizadora da experiência pública e
da resolução de conflitos. (CARRANO, 2007, p-65)

Se a diversidade de gênero e faixa etária marca os sujeitos da EJA e necessita ser considerada na constituição das propostas educativas, a identidade de classe desses educandos é importante ponto de encontro das trajetórias de vida e escolaridade variadas. Não apenas os estudantes adolescentes, como também adultos e idosos, mulheres e homens compartilham experiências de exclusão, vivenciam a difícil realidade das periferias da cidade, com moradias precárias, baixo acesso aos bens e equipamentos culturais, da carência de serviços de saúde e transporte na cidade. Eles frequentemente ocupam posições subalternas e possuem relações de trabalho informais com baixos rendimentos. Sofrem e testemunham violência e preconceitos.

No cenário em que os direitos não são plenamente concretizados pelo Estado, essas experiências se associam às suas expectativas sobre o trabalho como via de acesso a serviços 
como saúde, educação, transporte, lazer. Associam-se também à relação entre escolarização e empregabilidade. O perfil ocupacional dos estudantes dos CEMES em 2002 e suas expectativas de qualificação profissional também subsidiariam a concepção do Projeto CIEJA. Segundo o Relatório de Pesquisa de caracterização de alunos, 63\% dos estudantes trabalhavam fora, sendo que 75,3\% eram homens e 53,8\%, mulheres. Dentre os alunos trabalhadores 49,5\% tinham carteira assinada e 32,5\% não possuíam registro. Dos empregados e autônomos, $8 \%$ não declararam se a relação de trabalho era formalizada.

Quanto ao rendimento, $32 \%$ dos estudantes possuíam rendimento de 1 a 2 salários mínimos e $24 \%$ de 2 a 3 salários mínimos, que correspondia à época ao valor de duzentos reais. O relatório apontava, ainda, que $36 \%$ não estavam ocupados, incluídos os desempregados, as donas de casa, aqueles que não haviam ingressado no mercado de trabalho, os aposentados, licenciados por doença, os que recebiam algum tipo de benefício de programas governamentais e os que não responderam. (DOT-EJA/SENAC-SP, 2002, p.8-9).

Entre a população economicamente ativa (PEA), os jovens eram os mais atingidos pelo desemprego, reforçando os mecanismos de exclusão social (SPÓSITO, 2003, p.7). A situação da juventude diante do mercado de trabalho pode ser um dos fatores que ao mesmo tempo justifica seu afastamento da escola para trabalhar e seu retorno aos estudos para buscar a formação escolar básica para atender às oportunidades de emprego cada vez mais seletivas.

Tabela 8- Alunos dos CEMES ocupados segundo o setor de atividade

\begin{tabular}{|c|c|c|}
\hline Setor de atividades & $\mathbf{n}^{\mathbf{o}}$ & $\%$ \\
\hline Total & 3339 & 100 \\
\hline Serviços domiciliares & 1033 & 31 \\
\hline Comércio de mercadorias & 504 & 15,1 \\
\hline Outras indústrias, mal ou não definidas & 247 & 7,4 \\
\hline Serviços pessoais & 202 & 6,1 \\
\hline Serviços de alojamento e alimentação & 176 & 5,3 \\
\hline Indústrias metalúrgicas e mecânicas & 178 & 5,3 \\
\hline Indústria da construção civil & 153 & 4,6 \\
\hline Transportes & 147 & 4,4 \\
\hline Ensino público e privado & 81 & 2,4 \\
\hline Outras atividades sem especificação & 77 & 2,3 \\
\hline Serviços na reparação e conservação & 74 & 2,2 \\
\hline Indústrias no domicílio & 73 & 2,2 \\
\hline Telefonia & 64 & 1,9 \\
\hline Serviços auxiliares e de escritório & 60 & 1,8 \\
\hline Administração pública & 56 & 1,7 \\
\hline
\end{tabular}


(continuação)

\begin{tabular}{llll}
\hline Setor de atividades & $\mathbf{n}^{\mathbf{0}}$ & $\mathbf{\%}$ & \\
\hline Indústrias gráficas & 52 & & 1,6 \\
Serviços de diversão, radiodifusão, TV. & 21 & & 0,6 \\
Sem resposta & 18 & & 0,5 \\
Serviços comunitários e sociais & 12 & 0,4 \\
\hline
\end{tabular}

Fonte: Adaptada do Relatório de Pesquisa Caracterização de alunos (DOT-EJA/SENAC-SP, 2002).

Comparando a tabela anterior à caracterização dos educandos de Suplência I em 1989, constatamos também as condições dos jovens e adultos no mercado de trabalho, em que predominam as ocupações nos setores de serviços, comércio e indústrias, verificando-se entre 1989 e 2002, a ocupação nas indústrias diminui, enquanto no comércio aumenta.

\section{Tabela 9 - Profissão dos estudantes de Suplência I em 1989}

\begin{tabular}{rccc}
\multicolumn{1}{c}{ Profissão } & Homens & Mulheres & Total \\
\hline Domésticos & $18,40 \%$ & $21, \& \%$ & $40,19 \%$ \\
Operários & $17,30 \%$ & $9,90 \%$ & $27,22 \%$ \\
Desempregados & $12,50 \%$ & $10 \%$ & $22,50 \%$ \\
Comerciários & $4 \%$ & $1,90 \%$ & $6 \%$ \\
Autônomos & $1,80 \%$ & $1,40 \%$ & $3,20 \%$ \\
Ambulantes & $0,50 \%$ & $0,40 \%$ & $0,90 \%$ \\
\hline
\end{tabular}

Fonte: Relato de Práticas Pedagógicas, SME/ DOT-EDA, 1992

Os números dos anos de 1989 e de 2002 nos dão pistas de que, embora a ampliação da escolaridade dos educandos se apresente como fator importante para o acesso a oportunidades de trabalho, não necessariamente se traduziram na modificação dos setores que as classes mais pobres ocupavam. Segundo Pochmann (2005):

De certa forma, ampliou-se consideravelmente o processo discriminatório no interior do mercado de trabalho, sobretudo entre distintas faixas etárias (jovens e adultos), raças e gênero. Tal círculo vicioso impediu que a educação revelasse o seu potencial transformador das relações humanas e da agregação de valor à produção no Brasil. (POCHMANN, 2005, p- 384)

As características relativas à ocupação, gênero e faixa etária entre os estudantes da EJA denotam, ao longo da história, que a diversidade entre esses sujeitos, potencialmente enriquecedora e transformadora das relações sociais, ratifica traços de discriminação.

Essa diversidade também é composta pelo grande número de estudantes com necessidades educacionais especiais matriculados nos CIEJAs, como já apresentavam os 
pareceres $^{48}$ do Conselho Municipal de Educação (CME), apontando que algumas unidades “atenderam a um grande número de estudantes com necessidades educacionais especiais e foram acompanhados por professores das salas de apoio pedagógico (SAAI) ${ }^{49}$ ". (CME, PARECER 144/2009). Nos últimos anos apresenta-se bastante superior ao restante das unidades que ofertam a modalidade EJA na cidade.

Em 2011, esse fato se confirma, sendo que "o atendimento aos alunos com necessidades educacionais especiais aumentou consideravelmente e alguns CIEJA não conseguiram absorver a demanda por falta de espaço para abertura de novas salas". (CME, PARECER228/11).

Tabela 10 - Matrícula de estudantes com necessidades educacionais especiais no Ensino Fundamental/ EJA Total (Inclusão)

\begin{tabular}{|c|c|c|c|c|c|c|c|c|c|c|c|c|c|c|c|}
\hline \multicolumn{16}{|c|}{$\begin{array}{c}\text { Necessidades Educacionais Especiais - Ensino Fundamental/ EJA Total (Inclusão) } \\
\text { EJA }\end{array}$} \\
\hline \multirow[b]{2}{*}{$\begin{array}{c}\text { Necessidade } \\
\text { especial }\end{array}$} & \multicolumn{3}{|c|}{ TOTAL- EJA } & \multicolumn{4}{|c|}{ EMEFs } & \multicolumn{4}{|c|}{ Modular } & \multicolumn{4}{|c|}{ CIEJA } \\
\hline & Total & $\begin{array}{c}\text { EJA } \\
\mathbf{I}\end{array}$ & $\begin{array}{c}\text { EJA } \\
\text { II }\end{array}$ & $\begin{array}{c}1^{\mathrm{a}} \\
\text { Etapa }\end{array}$ & $\begin{array}{c}2^{\mathbf{a}} \\
\text { Etapa }\end{array}$ & $\begin{array}{c}3^{\mathbf{a}} \\
\text { Etapa } \\
\end{array}$ & $\begin{array}{c}4^{\mathbf{a}} \\
\text { Etapa }\end{array}$ & I & II & III & IV & $\begin{array}{c}\text { Mód. } \\
\text { I }\end{array}$ & $\begin{array}{c}\text { Mód. } \\
\text { II }\end{array}$ & $\begin{array}{l}\text { Mód. } \\
\text { III }\end{array}$ & $\begin{array}{l}\text { Mód. } \\
\text { IV }\end{array}$ \\
\hline $\begin{array}{l}\text { Altas Habilidades/ } \\
\text { Superdotação }\end{array}$ & 6 & 1 & 5 & & & 1 & 4 & & & & & & 1 & & \\
\hline Autismo & 31 & 13 & 18 & & 2 & & 4 & & & & & 4 & 7 & 5 & 9 \\
\hline $\begin{array}{l}\text { Baixa Visão/Visão } \\
\text { Subnormal }\end{array}$ & 28 & 7 & 21 & & 3 & 2 & 8 & & & & 1 & 1 & 3 & 5 & 5 \\
\hline Cegueira & 16 & 7 & 9 & & & & & & & & & 3 & 4 & 3 & 6 \\
\hline $\begin{array}{l}\text { Condutas Típicas } \\
\text { Deficiência } \\
\text { Auditiva }\end{array}$ & 0 & & & & & & & & & & & & & & \\
\hline $\begin{array}{l}\text { Def. Física/ Não } \\
\text { cadeirante }\end{array}$ & 78 & 28 & 50 & 3 & 4 & 4 & 12 & & & & & 3 & 18 & 19 & 14 \\
\hline $\begin{array}{l}\text { Def. Física/ } \\
\text { Cadeirante }\end{array}$ & 30 & 17 & 13 & & 1 & & 1 & & & & & 8 & 8 & 4 & 8 \\
\hline Def. Intelectual & 946 & 411 & 535 & 13 & 42 & 53 & 76 & 2 & 2 & 8 & 10 & 127 & 225 & 220 & 168 \\
\hline Def. Múltipla & 73 & 44 & 29 & 1 & 3 & 1 & 7 & 1 & & & & 17 & 22 & 13 & 8 \\
\hline Def. Visual & 0 & & & & & & & & & & & & & & \\
\hline Síndrome de Down & 0 & & & & & & & & & & & & & & \\
\hline $\begin{array}{l}\text { Surdez } \\
\text { Leve/Moderada }\end{array}$ & 24 & 10 & 14 & & 1 & 1 & 5 & & & & 1 & 2 & 7 & 2 & 5 \\
\hline $\begin{array}{l}\text { Surdes } \\
\text { Severa/Profunda }\end{array}$ & 40 & 27 & 13 & & 1 & 1 & 4 & & & 1 & & 4 & 22 & 5 & \\
\hline Surdocegueira & 2 & 1 & 1 & & & & & & & & & & 1 & 1 & 2 \\
\hline
\end{tabular}


(continuação)

\begin{tabular}{|c|c|c|c|c|c|c|c|c|c|c|c|c|c|c|c|}
\hline \multirow[b]{2}{*}{$\begin{array}{c}\begin{array}{c}\text { Necessidade } \\
\text { especial }\end{array} \\
\end{array}$} & \multicolumn{3}{|c|}{ TOTAL- EJA } & \multicolumn{4}{|c|}{ EMEFs } & \multicolumn{4}{|c|}{ EJA Modular } & \multicolumn{4}{|c|}{ CIEJA } \\
\hline & Total & $\begin{array}{c}\text { EJA } \\
\mathbf{I}\end{array}$ & $\begin{array}{c}\text { EJA } \\
\text { II } \\
\end{array}$ & $\begin{array}{c}1^{\mathrm{a}} \\
\text { Etapa }\end{array}$ & $\begin{array}{c}2^{\mathbf{a}} \\
\text { Etapa }\end{array}$ & $\begin{array}{c}3^{\mathbf{a}} \\
\text { Etapa }\end{array}$ & $\begin{array}{c}4^{\mathrm{a}} \\
\text { Etapa }\end{array}$ & I & II & III & IV & $\begin{array}{c}\text { Mód } \\
\text { I }\end{array}$ & $\begin{array}{c}\text { Mód. } \\
\text { II }\end{array}$ & $\begin{array}{c}\text { Mód. } \\
\text { III }\end{array}$ & $\begin{array}{c}\text { Mód. } \\
\text { IV }\end{array}$ \\
\hline Síndrome de Rett & 10 & 4 & 6 & 2 & 1 & 2 & 2 & & 1 & 1 & & & & 1 & \\
\hline $\begin{array}{l}\text { Transf. } \\
\text { Desintegrativo } \\
\text { Infância }\end{array}$ & 12 & 1 & 11 & & & 5 & 5 & & & & & 1 & & & \\
\hline $\begin{array}{l}\text { Síndrome de } \\
\text { Asperger }\end{array}$ & 0 & & & & & & & & & & & & & & 1 \\
\hline TOTAL & 1296 & 571 & 725 & 19 & 58 & 70 & 128 & 3 & 3 & 101 & 12 & 170 & $318 \quad 2$ & 278 & 226 \\
\hline
\end{tabular}

Fonte: PMSP. SME. CI.Sistema Escola On-Line e Sistema SIGPEC (RH). Data Base: 30/Março/2013

Em 2013, os dados apresentam que a concentração desses alunos nos CIEJAs é bastante superior à sua distribuição no restante das unidades da rede que atendem a essa modalidade de ensino. Soma-se a isso, o fato de que nas salas de aula pequenas a proporção desses alunos é maior do que aqueles sem necessidades educacionais especiais diagnosticadas, uma vez que em espaços improvisados, por vezes a lotação da turma é bem inferior a 35 alunos. Assim, a observação da tabela acima revela uma espécie de "inclusão" às avessas, em que algumas salas de aula dos CIEJAs mais parecem salas especiais.

Esses dados suscitam perguntas que fogem ao recorte de nossa pesquisa, no entanto, são tangenciadas nas entrevistas realizadas e vivenciadas intensamente no cotidiano dessas unidades. Por que os jovens e adultos com necessidades educacionais especiais estão concentrados nos CIEJAs da cidade? Quais políticas educacionais ou de inclusão justificariam essa realidade? Qual o objetivo dessa concentração ou, ainda, que outros espaços e políticas de inclusão atendem a esses estudantes?

Podemos questionar ainda a alta concentração de pessoas com deficiência intelectual na EJA, quando comparada com a presença de pessoas com outros tipos de deficiência, o que indica maior dificuldade dos sistemas escolares em integrarem e desenvolverem práticas escolares condizentes às necessidades e tempos de vida das pessoas com deficiência intelectual, que chegam à idade adulta sem escolaridade básica.

A entrevistada Êda Luiz, Coordenadora Geral do CIEJA Campo Limpo trata dessa realidade como um dos desafios do trabalho nos CIEJAs. A fala da educadora revela que além da necessária inclusão dos estudantes nas salas de aula é preciso refletir sobre a qualidade da educação para os jovens e adultos com necessidades educacionais especiais. 
Essa qualidade ultrapassaria as ações da escola e requer a articulação de diferentes atores e programas para que os alunos possam continuar os estudos, sob pena de que a ideia de inclusão passe a significar a reiteração da discriminação quando reduzem as expectativas de aprendizagem ou participação desses sujeitos para além das salas de aula. É nesse sentido que a diversidade apresentada pelos estudantes da EJA necessita ser consideradas de maneira integrada por políticas públicas de diferentes setores.

Outro dia passaram por aqui uma porção de programas ${ }^{50}$, eu fico escrevendo na
lousa, eu acho que tinha mais de 15 programas, que estavam aqui, que cuidam de
pais, adolescentes, e ninguém conversa, né? (...) Falei: Não, pode parar. Gente, eu
vou chamar todos os programas e a gente vai se achar nessa história toda. (...)
Porque, assim, tem um esforço enorme, mas está desarticulado. Então, eu vou trazer
a Saúde, a Assistente Social, para ver direito como é que está a família, porque às
vezes se faz uma coisa em casa e aqui é outra. Será que essa família também não
precisa de ajuda? E onde está? (Êda Luiz, dezembro de 2012)

Nota-se também em sua fala, que a escola possui um papel importante na viabilização do acesso aos diversos programas e atores voltados à questão da inclusão, uma vez que se torne espaço de encontro e reflexão coletiva.

As práticas de ensino também poderiam cumprir papel relevante na integração entre o conhecimento escolar e participação social, como aponta a Professora Célia Borges do CIEJA Butantã ao tratar das aulas de "Itinerário Formativo em Agente Cultural de Mídia Rádio", em que os estudantes levantam, estudam e promovem discussões:

Existe toda uma aparelhagem pública do país, eu acho que a gente ainda se
relaciona pouco com ela, poderia fazer mais isso, tem condição de fazer, de interferir
mais, de criar projetos que saíssem do escolarizado. Assim, eu acho que a gente
trabalha com adulto e a gente tem que ser escolar, porque é escola, tá; mas pode
propor práticas que, ao mesmo tempo respeitam todo o processo pedagógico de
aprendizado e se efetivem na realidade. É assim que eu vejo o Projeto da Rádio.
(Célia Borges, outubro de 2012)

A proposta curricular dos CIEJAs pretende abranger as especificidades dos educandos, com tempos, espaços e currículos que integrem a formação profissional e cidadã. Aponta-se, porém, que as políticas educação precisam de articulação com as demais, para que as escolas não sejam espelho de conflitos sociais e discriminação, mas espaço de integração e transformação social.

\footnotetext{
${ }^{50}$ Êda se referia a programas e projetos sociais e da SME que tinham como público-alvo os estudantes com necessidades educacionais especiais.
} 


\title{
3.2 O modelo de organização escolar CIEJA: tempo, currículo e espaço
}

O perfil dos estudantes foram indicadores importantes para o redimensionamento das políticas públicas de EJA e constituição dos CIEJAs na cidade de São Paulo. Vimos que os dados de 1989 subsidiaram as propostas da gestão de Luíza Erundina (1989 a 1992) para a modalidade de ensino, inclusive para o desenho original dos CEMES no final de seu mandato (1992).Do mesmo modo, os perfis dos estudantes dos CEMES foram utilizados como indicadores importantes para realizar escolhas políticas na gestão de Marta Suplicy, orientando a avaliação das unidades educacionais, os "itinerários a serem implantados em cada unidade escolar e outras decisões relativas ao currículo, operacionalização e concepção dos Novos Centros" (DOT-EJA/SENAC-SP, 2001, p.5). Também na gestão de Kassab (2006-2009), a diversidade dos sujeitos da EJA e as condições de jovens e adultos enquanto trabalhadores justificaram a Reorientação Curricular da EJA e impactaram na percepção de que o modelo dos CIEJAs atenderia às necessidades dos estudantes.

A condição dos educandos enquanto jovens e adultos trabalhadores, pais e mães com diferentes responsabilidades familiares, origens e trajetórias de vida provocaram um sentido de flexibilidade do tempo e currículo escolar, confirmando a conclusão de Haddad (2007) sobre os estudos que abordam propostas diferenciadas para a EJA no âmbito nacional:

\begin{abstract}
A flexibilidade nos horários de entrada e saída, a não-cobrança de presença, a frequência de acordo com o desempenho e/ou interesse em uma disciplina ou projeto, ou campo de interesse, tudo isso aponta para uma forma de conceber a escola e o seu currículo que, no limite, indicam sinais para uma nova forma de fazer EJA, superando o modelo tradicional, cuja reposição acelerada do currículo do ensino regular é a principal característica, e os alunos tratados de forma homogênea, classificados por série. Dar atenção a essas diferenças e tratá-las a partir da diversidade de necessidades de aprendizagem são condições necessárias para oferecer aos educandos uma escola voltada aos seus interesses. (HADDAD, 2007, p. 17)
\end{abstract}

Nota-se que, no momento da implantação dos CEMES na cidade de São Paulo, durante o governo Maluf (1993-1996), a flexibilidade de organização do tempo, currículo e espaços fora concebida sob a lógica da instrução individualizada.

\section{Objetivo do CEMES}

- Oferecer o ensino fundamental na modalidade supletiva cuja metodologia concilie qualidade e flexibilidade, proporcionando condições para que o aluno adquira autonomia na busca do conhecimento.

- Proporcionar um processo de escolarização que respeite a identidade cultural do 
aluno e que contribua para reorganização do conhecimento construído ao longo de sua vida. (SME/DOT, 1994, p. 07)

Muito embora conste no projeto do CEMES a diferenciação necessária entre o ensino de adultos e crianças, esse discurso se esvaziava diante da visão de currículo baseada na tradição do Ensino Supletivo, ou seja, de reposição dos conteúdos escolares do Ensino Fundamental. A fragmentação das disciplinas em Unidades de Estudos e a organização de módulos de aprendizagem baseavam-se no conglomerado de créditos a serem cumpridos em cada unidade disciplinar. Assim, o currículo não apenas mimetizava aquele da escola básica de maneira acelerada, como implicava a individualização do ensino. Como observou Êda Luiz, primavase pela memorização de conteúdos e não propriamente por sua apreensão crítica, reduzindo o processo de ensino e aprendizagem à transmissão e reprodução de conhecimentos. Desse modo, mais do que a flexibilização do currículo escolar, observamos a flexibilidade do tempo de estudo, alicerçado em práticas que tendiam à minimização da importância do professor enquanto mediador do conhecimento e a aceleração dos cursos.

O professor no CEMES:

- facilitador do autodesenvolvimento

- humano, capaz de sentir o outro aluno - como alguém "dotado de dons ou talentos"

- predisposto a auxiliá-lo na identificação dos próprios talentos

- respeitador da individualidade, contribuindo para o alcance da maestria pessoal

- estimulador, favorecendo a caminhada e predispondo o aluno a:

- aplicar-se - estudo individual

- persistir - vencer etapas - fascículos

- reinspirar-se - a cada dificuldade vencida, passar para a outra (SME/ DOT, 1994, p. 05)

Durante a vigência dos CEMES, prevalecia uma visão compensatória da EJA que conferia aos estudantes a responsabilização por sua formação. O respeito à individualidade era o mote do projeto implantado e relaciona-se à visão do aluno como um cliente, cujo aprendizado resultava de mérito individual.

(...) as modalidades de ensino a distância que não provêm o suporte regulador do educador e de um grupo de colegas não parece ser o mais adequado para o ensino fundamental, não menos para a grande maioria dos que necessitam essa modalidade educativa, constituída de pessoas que foram alijadas não só da escola, mas também dos espaços sociais em que predomina a cultura escrita. (RIBEIRO, 1999, p. 196)

Desconsiderando os limites da autonomia estudantil para o estudo, principalmente nos módulos III e IV, em que não havia grupos-classe, a adoção dessa metodologia também facilitava a desresponsabilização do município em realizar maiores investimentos nessa modalidade de ensino.

O sentido de flexibilidade então adotado justificava a redução do número aulas, de 
professores e até mesmo de infraestrutura, já que ao promover o atendimento individualizado, os espaços de funcionamento dos Centros eram também improvisados.

Os CEMES no Campo Limpo, conforme relato de Êda Luiz, funcionava em um centro evangélico, cujo espaço era cedido. Com o tempo, o conflito entre as atividades escolares e da Igreja pressionaram pelo aluguel de um prédio residencial na mesma região.

Já para o CEMES Butantã, o espaço de funcionamento foi reduzido a pequenas salas em diferentes escolas durante os primeiros anos. Inicialmente, os professores preparavam materiais de avaliação por não terem condições de atendimento ao estudante. Após os primeiros anos de CEMES é que se alugou também uma casa residencial no bairro.

Como observamos, a acepção da flexibilidade nos CEMES seria modificada no momento da criação do Projeto CIEJA, no governo de Marta Suplicy (2001-2004). Passava-se a promover o direito ao ensino presencial. Reconhecia-se também a necessidade de que as condições de acesso e permanência dos educandos na escola demandavam uma diferente ordenação dos espaços, dos tempos de estudo e um currículo apropriado.

No intuito de promover maiores possibilidades para os educandos frequentarem a escola, não somente o tempo de aula diário foi diminuído, como se distribuiu de maneira que fosse possível realizar a reposição de aulas em períodos diferentes. A reordenação do tempo estaria atrelada ao redimensionamento curricular. Passava-se a contabilizar atividades extraescolares na carga horária. O modelo do Projeto CIEJA seria organizado da seguinte maneira:

O curso é presencial e os encontros são organizados de modo que os educandos
matriculados nos Centros permanecem 2 horas e 15 minutos/dia, durante 4 dias na
semana. Visando atender ao educando trabalhador, os encontros foram organizados
nos seguintes horários: das $7 \mathrm{~h} 30$ às $9 \mathrm{~h} 45$; das $10 \mathrm{~h} 00$ às $12 \mathrm{~h} 15$; das $13 \mathrm{~h} 00$ às $15 \mathrm{~h} 15$;
das $15 \mathrm{~h} 30$ às $17 \mathrm{~h} 45$; das $17 \mathrm{~h} 45$ às $20 \mathrm{~h} 00$ e das $20 \mathrm{~h} 15$ às $22 \mathrm{~h} 30$. Os educadores
atendem a duas turmas de educandos/dia e, durante 4 dias da semana (de segunda a
quinta-feira) e, às sextas-feiras, todos participam do horário coletivo de formação.
(SME/DOT, 2004, p.6)

Destaca-se na organização acima, a manutenção de horários diferenciados para atendimento dos estudantes, durante o dia todo, não apenas à noite como tradicionalmente são ofertadas as propostas de EJA. Esse fato advinha da percepção de que muitos estudantes, trabalhadores de turno, oudo setor de serviços no período noturno (como os garçons, cozinheiros, porteiros, manobristas) necessitavam de horários alternativos para o estudo. Além disso, os idosos e mulheres que trabalhavam em casa também frequentariam os períodos diurnos, devido ao transporte, segurança e tempo livre, como informou a ex-diretora de DOT 


\section{Marisa Darezzo.}

Também é relevante destacar a organização do trabalho dos professores, que assumiam duas turmas de educandos por dia e tinham a sexta-feira livre para o horário coletivo de formação. Isso demonstra que os educadores não só voltavam a ocupar papel central no processo de ensino-aprendizagem, como se considerava fundamental a sua formação coletiva e condições de trabalho para desenvolver uma nova proposta curricular.

Se desde o CEMES, os professores já tinham uma organização de trabalho diferenciada, com tempo para elaboração das avaliações das Unidades de Ensino, nos CIEJAs essa organização deixa de enfatizar a avaliação de conteúdos transmitidos aos estudantes, para enfocar a elaboração de um currículo diferenciado e seu desenvolvimento mediante metodologias de ensino apropriadas.

A busca pela construção de uma nova forma de fazer educação que pudesse fazer a integração do Ensino Fundamental e a Educação Profissional Básica exigiu um olhar mais atento dos educadores para a prática pedagógica e a sua relação com as teorias que a fundamentam e isso exigiu, por parte da SME/DOTEJA, um investimento na formação dos educadores dos Centros. (SME/DOT, 2004, p.7)

O currículo dos CIEJAs continuaria organizado em módulos de aprendizagem, recuperava-se, porém, a concepção de EJA sob o paradigma da Educação Popular, tal como o projeto inicial do CEMES postulava em 1992, no final da gestão Erundina. Observamos, abaixo, que os objetivos do CIEJA mantêm no segundo ponto o mesmo objetivo do CEMES, em relação ao respeito à identidade cultural do estudante e seus saberes. No entanto, os sentidos de flexibilidade passavam a se modificar, na medida em que se concebia o conhecimento como construção coletiva, devendo mirar compromissos sociais e políticos, tais como a solidariedade e participação democrática.

Art. $7^{\circ}$ - No âmbito educacional os CIEJAS têm por objetivo:

I. oferecer uma escola cuja flexibilidade democratize o acesso e a permanência dos jovens e adultos, promovendo a construção coletiva do conhecimento e a orientação para o mundo do trabalho e o mundo da cultura;

II. oferecer um processo de escolarização que respeite a identidade cultural do educando e que contribua para a reorganização do conhecimento construído ao longo de sua vida;

III. propiciar aos jovens e adultos condições para a construção coletiva do conhecimento, de modo que a sua inserção no mundo do trabalho favoreça o prosseguimento dos seus estudos em outros graus ou modalidades de ensino, assim como a outras oportunidades de desenvolvimento cultural;

IV. contribuir para a formação da consciência social, crítica, responsável, solidária e democrática, para que o educando, gradativamente, se perceba sujeito de sua própria educação e participante do processo de transformação da sociedade. (SME/DOT, 2002, p-5) 
O esforço em restabelecer o currículo escolar emancipatório, articulado à vivência dos estudantes e à "formação da consciência social, crítica, responsável, solidária e democrática", aparece em diferentes documentos do CIEJA, associado à metodologia de ensino construtivista sociointeracionista, além da priorização da interdisciplinaridade em oposição à fragmentação das disciplinas em Unidades de Estudo.

A metodologia a ser adotada no CIEJA atenderá aos princípios do paradigma do
construtivismo sócio-interacionista, que envolve dialogicidade, projetos,
problematização, interação grupal, integração curricular e autonomia operatória e que
pressupõe: uma práxis que compreenda o movimento de ação-reflexão-ação, a partir
da articulação entre o saber popular e o saber elaborado como espaço de luta pelos
direitos civis, políticos, sociais e econômicos; a orientação para o mundo do
trabalho, desenvolvida de formas integrada entre os componentes curriculares que
comporão os Itinerários Formativos (articulando Educação Fundamental e
Profissional); o respeito à identidade cultural dos educandos, numa relação de troca
de experiência e de diálogo, momento de reelaboração do conhecimento;
reconhecimento de que professores e alunos trazem saberes diferentes e que precisam
ser explicitados para superar o senso comum, valendo-se dos saberes já acumulados e
sistematizados pela humanidade; o estímulo à curiosidade e à criatividade de todos os
envolvidos no processo;o desenvolvimento de um trabalho coletivo permanente que
atenda à autonomia e à recuperação do papel do educador pesquisador da realidade, à
reflexão e à intervenção sobre a construção coletiva; o exercício da cidadania por
meio da interação escola - comunidade, das relaçães de parceria, da articulação com
os diversos segmentos da sociedade. (DOT, 2003, p.5)

Lembramos que o projeto original do CEMES era permeado da proposta de interdisciplinaridade, um dos eixos de formação docente no período de atuação de Paulo Freire na SME. Essa recuperação da proposta interdisciplinar basearia a organização das disciplinas em áreas do conhecimento: Linguagens e Códigos, Ciências da Natureza e Matemática e Ciências Humanas. A distribuição da carga horária por área de conhecimento e não por disciplinas individualizadas, mirava que cada área pudesse desenvolver um projeto de aprendizado articulado com diferentes campos do conhecimento.

Esse sistema visaria que o estudante vivenciasse a investigação, a proposição de soluções e acessasse o conhecimento formal de maneira significativa, com respeito ao seu conhecimento prévio e seu tempo de aprendizagem. Os Centros organizavam seu espaço e tempo, tendo em vista o tempo de ensinar, o tempo de aprender, o tempo da convivência, da pausa, da recreação.

Os estudantes poderiam, também, optar por extrapolar as horas de estudo com as chamadas Orientações de Estudo (OE), em que era possível tirar dúvidas, aprofundar-se em algum tema, desenvolver ou participar de projetos diferenciados. A atribuição de aulas aos professores por turmas, períodos e áreas de conhecimento permitia que houvesse 
periodicamente pelo menos um docente livre para ministrar as OEs.

Observamos também que a articulação entre "o mundo da cultura" e o "mundo do trabalho" subsidiaria a integração dos Itinerários Formativos de Qualificação Profissional ao currículo escolar e agregaria o ensino por competências.

Art. 54 - O currículo é parte integrante na ação educacional desenvolvida nos CIEJAs, voltada para os objetivos educacionais na perspectiva de educação integral e transformadora, e tem como base, em sua organização, os seguintes princípios:

I. construtivismo sócio-interacionista - concebe-se a educação como uma prática que tem a possibilidade de criar situações em que o conteúdo, visto como insumo, seja trabalhado de forma contextualizada e significativa. Os conhecimentos e habilidades prévios dos alunos são ponto de partida para a resolução de problemas, cabendo ao professor estimular a pesquisa, a descoberta e a construção de instrumentos de compreensão da realidade e participação em relações sociais, políticas e culturais diversificadas e cada vez mais amplas;

II. ênfase no desenvolvimento de competências - entendidas como capacidade pessoal de articular e colocar em ação os saberes inerentes às situações concretas da vida social e do trabalho, refletindo um paradigma educacional com foco no processo de aprendizagem e no aluno como sujeito deste processo;

III. itinerário formativo atuando como fio condutor para a articulação entre a educação básica e a profissional e envolvendo as competências básicas e específicas das diferentes qualificações oferecidas:

IV. organização do currículo em módulos flexíveis, sequenciais e progressivos, podendo esses módulos ser constituídos a partir de projetos e outras situações de aprendizagem que articulem e mobilizem os componentes necessários para o desenvolvimento das competências;

V. flexibilidade - organizar o currículo dentro de uma estrutura de tempo e espaço que atenda às necessidades e características da clientela da Educação de Jovens e Adultos, de maneira a viabilizar os objetivos dos CIEJAs;

VI. diálogo e interação grupal - as diversas experiências dos alunos, professores e demais participantes da vida escolar devem contribuir para constituição de identidades afirmativas, persistentes e capazes de protagonizar ações autônomas e solidárias em relação aos conhecimentos e valores indispensáveis à vida cidadã;

VII. interdisciplinaridade - indo além da justaposição de disciplinas, evita sua diluição na generalidade e as integra através de atividades, projetos, pesquisa e ações, numa prática pedagógica adequada à Educação de Jovens e Adultos. (SME/DOT,2002, p.17)

Constata-se que o currículo possui certo hibridismo entre o paradigma de Educação Popular e a concepção de educação ao longo da vida. Fazer convergir as duas vertentes ficaria, então, a critério de cada Centro e suas práticas. Se de fato o conceito de educação ao longo da vida contempla a formação dos sujeitos, atendendo as necessidades e trajetórias individuais, compromisso social e político de solidariedade e democratização, pode ser compreendida como sinônimo de qualificação profissional voltada ao atendimento dos interesses de mercado, conforme alerta Lima (2005).

Lima (2005) destaca que a constituição de currículos por competências revela que o campo pedagógico tem sido permeado pelas lógicas da economia, ou seja, as políticas 
educacionais são regidas pela política econômica, imperando a competição como fundamento das mudanças curriculares. É o que observa no uso do termo "competência para competir" utilizado em diferentes propostas educativas de Portugal.

\begin{abstract}
Creio que, muito mais do que simbolicamente, o lema político-pedagógico da «aquisição de competências para competir» remete para o protagonismo do mercado, da privatização e dos processos de individuação, acentuando o carácter pragmático, instrumental e competitivo da educação e da formação. Neste sentido, como tenho chamado à atenção, a expressão «competências para competir » não deixa de ser pleonástica, acentuando ainda mais os elementos de competição e de emulação que são já inerentes ao próprio vocábulo competência. De facto, competência significa também disputa, luta e conflito na busca da mesma coisa por parte de dois ou mais sujeitos competidores, que assim rivalizam, e desta forma implica hostilidade em vez de cooperação e de solidariedade. (LIMA, 2005, p. 84)
\end{abstract}

O conceito de educação ao longo da vida abordado por Delors (1996) reafirma a necessidade de equalizar a competição que estimula, a cooperação que reforça e a solidariedade que une. Desse modo, a formação profissional não poderia ser desarticulada da propedêutica e restrita à competição de mercado.

Superar a tensão entre a mão direita e esquerda da educação ao longo da vida (LIMA, 2007) era desafio posto ao currículo dos CIEJAs na cidade. Os documentos de SME apontam para um sentido diferente do currículo por competências, referindo- se às práticas educativas que levem os conhecimentos teóricos à aplicação na social. A formação para o mundo do trabalho, enquanto lugar de constituição da identidade e cultura é fundamental para que se amplie a formação dos cidadãos para economia sustentável, não puramente capitalista.

Obviamente que não concebemos um sistema educativo que não tenha em
consideração o mundo laboral, que não se preocupe por oferecer a cada estudante a
preparação necessária para participar activamente na sua comunidade, para trabalhar
nela e para ela. A perspectiva crítica que temos vindo a desenvolver refere-se a que
não assumimos que o sistema educativo só tenha sentido para preparar trabalhadores
e trabalhadoras para um mercado no qual a desigualdade de oportunidades e a
repartição da riqueza se produz de maneira muito injusta; um mundo no qual, dia a
dia, se reduzem as possibilidades de participar democraticamente na definição do
tipo de sociedade que mais pode beneficiar a todos, na qual a igualdade de
oportunidades seja real e não um mero slogan que serve para ocultar um mundo não
solidário e injusto, um mundo no qual as cartas estão distribuídas de modo muito
desigual. (SANTOMÉ, 2001, p. 58)

De fato, quando o Projeto CIEJA enfatiza, ao lado do currículo por competências, pressupostos da Educação Popular, aponta para a potencialidade de formar sujeitos participantes "do processo de transformação da sociedade". Verifica-se, porém, o permanente conflito entre os sentidos dessa participação: podia ser compreendida como impulsionadora da cidadania ativa, ou como adaptação dos indivíduos à realidade social e econômica neoliberal. 
O Regimento do Projeto CIEJA possibilitava diferentes interpretações dos conceitos polissêmicos de "participação" e "democratização", ora apontando a preconização de mecanismos que favorecessem a gestão democrática, ora a necessidade de atender às demandas econômicas.

Art. 53 - No âmbito do Currículo, os CIEJAs têm por objetivo:

I. resgatar o papel transformador da escola e toda sua potencialidade no sentido de construir o cidadão atuante, crítico e em reais condições de buscar novas alternativas de se inserir na economia e de participar do processo sociocultural;

II. desenvolver ação educacional que permita o acesso de jovens e adultos a um conjunto de informações e o pensar questões contemporâneas e emergentes, pela utilização de instrumentos que os levem a participar politicamente e dar conta das exigências educacionais, para encontrar novas alternativas de inserção na economia e na vida social;

III. desenvolver ações educacionais integrando a educação básica e a educação profissional para proporcionar aos jovens e adultos condições de laborabilidade, de forma que possam manter-se em atividade produtiva e geradora de renda em contextos socioeconômicos, facilitando a mobilidade e aumentando as oportunidades de trabalho;

IV. promover ações educacionais para jovens e adultos que permitam o diálogo, a criatividade e a auto-estima por meio da construção de espaços onde o aluno possa refletir sua condição e pensar alternativas de sobrevivência, para entender e participar do mundo do trabalho e da cultura. (SME/DOT, 2002, p.12)

Esse conflito entre os sentidos, amparados em diferentes projetos políticos e de sociedade, seria solucionado de maneira diversa nas unidades de CIEJA, que dariam significados distintos aos conceitos a partir de suas práticas.

Nossa pesquisa não alcançou, no entanto, verificar as nuances dessas interpretações em cada unidade de ensino. O exame dessas práticas fogem ao nosso escopo de pesquisa, porém destacamos que a priorização da participação da comunidade escolar nas decisões locais, incentivando o pleno funcionamento dos espaços de participação estudantil, é considerado essencial para que se constitua o currículo da escola democrática.

Assim, entre as diretrizes do modelo CIEJA consta a gestão democrática das unidades e a participação ativa da comunidade escolar no processo de elaboração curricular. Os CIEJAs do Campo Limpo e Butantã, cujos profissionais alcançamos entrevistar, revelam algumas práticas que delineiam a participação dos discentes nos momentos de avaliação e reelaboração do projeto, tais como o fortalecimento dos Conselhos e a criação das Assembleias Estudantis. Nessas assembleias não apenas as questões de organização cotidiana são debatidas e têm resoluções encaminhadas, como também levantam necessidades de mudanças políticas, como é o caso da reivindicação da instalação do Ensino Médio nos CIEJAs.

A reclamação dos estudantes por um modelo de escola que seja parecido com aquele 
que vivenciam, ratifica sua maior adequação aos interesses e às condições reais de seu acesso e permanência nos Centros. Ao mesmo tempo, denuncia que o Estado carece de investimentos apropriados para essa modalidade de ensino.

Como fortalecimento dos espaços participativos e da criação de um currículo mais aproximado das demandas discentes, podemos destacar também o horário de formação docente nos Centros. As sextas-feiras, dedicadas inicialmente para formação dos professores em parceria com o SENAC-SP para elaboração coletiva da proposta curricular dos CIEJAs, tornaram-se efetivamente o momento de troca e autoformação, de estudo de casos e (re)invenção das próprias práticas.

Nota-se que o primeiro Projeto CIEJA, elaborado na gestão de Marta Suplicy, determinava que os Centros cumprissem os duzentos dias letivos, porém caso não coincidissem com o calendário escolar da rede, que se mantivesse a proporcionalidade. Se as atividades extraescolares formalizadas eram contabilizadas na carga horária, era possível, por exemplo, incorporar saídas culturais aos sábados e trabalhos escolares diferenciados em outros horários, além daqueles fixos da turma, para que as sextas-feiras pudessem ter livre o período intermediário (vespertino) destinado à formação docente.

Com o passar dos anos, a gestão tecnocrática dos Centros por SME questionaria a variação das atividades escolares em dias não acadêmicos ou horários diferenciados para as turmas. O CME julgaria que os CIEJAs não cumpriam os 200 dias letivos, devido a sua distribuição desatrelada dos horários e calendário do Ensino Fundamental para o restante da rede. Os problemas para fazer o registro das atividades extraescolares e as recomendações do CME pressionariam os Centros a diminuírem cada vez mais o horário coletivo de formação para ampliar o número de oficinas oferecidas às sextas-feiras nos horários vespertinos.

Se por um lado, isso significava a maior diversificação de possibilidades de frequência dos estudantes na escola, por outro, era um retrocesso na formação docente e na organização curricular.

Na gestão de Gilberto Kassab (2006-2012), verificamos que a problemática da distribuição de carga horária dos cursos atrelava-se, ainda, ao sistema informatizado de atribuição de aulas, em que prevalece a hierarquização das disciplinas, sendo destinado mais ou menos tempo de aula para cada um dos componentes curriculares. Desse modo, o número de aulas varia entre os docentes de diferentes disciplinas. O sistema de atribuição de aulas 
comum para toda rede municipal foi, por vezes, compreendido por DOT como incompatível com o modelo de organização dos CIEJAs, mobilizando uma série de discussões e justificativas dos Centros perante o órgão.

Destaca-se ainda, que o número de estudantes por sala de aula e a organização da distribuição de aulas por período, desde o início de funcionamento dos CIEJAs, relacionava-se à realidade local, tal como espaços disponíveis nas salas de aula improvisadas e organização dos períodos de atendimento diversificados.

O rearranjo da organização dos períodos e distribuição das aulas foi bastante diverso durante a gestão Kassab (2006-2012). Dependendo do entendimento e relação dos Centros com a Diretoria Regional de Ensino e com os Supervisores Escolares, as unidades de CIEJA rebatiam ou cediam às recomendações de "regularização" do sistema de atribuição de aulas. Dessa forma, em algumas unidades passou-se a compartimentar o período de $2 \mathrm{~h} 15 \mathrm{em}$ aulas de 45 minutos por disciplina; em outras, as turmas do primeiro período vespertino foram fechadas, pela inviabilidade do número de professores as atenderem (designada a quantidade de professores em relação ao número de horas das disciplinas e número de alunos).

Além disso, observa-se que nos Centros que dividiram as aulas por disciplina, os docentes não mais se responsabilizavam pelo atendimento de um só turno (manhã, tarde ou noite), mas passavam a atender, por vezes, os três.

Nossa pesquisa alcançou aferir a resistência dos CIEJAs Campo Limpo e Butantã; à regulação puramente tecnocrática da distribuição das aulas e organização curricular, articulando-se alternativas que possibilitassem a duração das aulas de $2 \mathrm{~h} 15$ e o trabalho docente por áreas de conhecimento. Entre elas, verifica-se a diversificação e ampliação das atividades de sexta-feira, o fortalecimento das Orientações de Estudos e atribuição de 3 horasaulas seguidas a um mesmo professor.

O Novo Projeto CIEJA $^{51}$ buscaria consolidar a atribuição de aulas docente, propiciando a manutenção da metodologia de ensino, flexibilidade de tempo e currículo do projeto original. Sobre a Equipe de Ensino, estabelece: “A designação deverá ocorrer de forma a garantir no mínimo um professor de cada disciplina dentro das Áreas do Conhecimento, a cada turno de funcionamento" (DOT/EJA/CIEJA, 2008, p. 31). Isso viabilizaria que em todos

\footnotetext{
${ }^{51}$ Lembramos que tivemos acesso ao Novo Projeto CIEJA encaminhado e aprovado por CME em documento original, cedido pelo CIEJA Butantã, devido sua não publicação por SME até o momento final da pesquisa.
} 
os períodos houvesse um professor de cada área, promovendo aos estudantes a possibilidade de repor aulas de determinada área de conhecimento em horário diferente daquele da turma que frequenta, ou seja, ampliava a flexibilidade do currículo e tempo de estudos.

O Novo Projeto inclui na matriz curricular as Orientações de Estudos e ainda sobre o horário dos educadores, determina:

O Horário dos Educadores de Módulo I e II dar-se-á em dois períodos preferencialmente seqüenciais, e deverão organizar-se dentro do turno para atender as Oficinas de Estudo. O Horário dos Educadores de Módulo III e IV - Áreas do Conhecimento - dar-se-á em períodos, preferencialmente seqüenciais, e deverão organizar-se dentro do turno para atender as Oficinas de Estudo e a demanda dos Módulos I e II, em extra classe - oficinas / aulas temas, quando esta se fizer necessário. O professor de Educação Física montará grupos de atendimento fora do horário regular para atendimento do alunado na forma da legislação vigente. $\mathrm{O}$ Horário Coletivo, obrigatório, composto de oito horas-aula semanais, deverá ser organizado de forma a garantir a participação de todos os docentes no mínimo de quatro horas-aula e as demais horas-aula serão destinadas ao desenvolvimento dos projetos, objetivando a consecução das metas do CIEJA. (DOT/EJA/CIEJA, 2008, p. 33)

O Novo Projeto CIEJA incorporaria também, entre suas concepções pedagógicas, os pressupostos da Educação Popular e da Aprendizagem ao longo da vida, novamente promovendo uma hibridização entre elas no que tange à organização do currículo que, ao mesmo tempo declarava-se interdisciplinar e por competências.

\begin{abstract}
A articulação entre a educação geral e a educação profissional básica, fundamentada na interdisciplinaridade, na dialogicidade e na interação grupal, permite a unidade do presente projeto, contribuindo para que o jovem e o adulto retomem seu potencial, confirmem competências adquiridas na educação extra-escolar e na própria vida e desenvolvam novas competências, possibilitando um nível profissional qualificado para o mercado de trabalho. (SMEQDOT/EJA, 2008, p.7)
\end{abstract}

Aproximando-se das diferenciações entre os Centros e divergências entre as metodologias e concepções adotadas em cada um, o Novo Projeto CIEJA compila as variadas realidades para a organização curricular, sem deixar de ratificar a importância de incorporar a diversidade e as demandas educativas dos estudantes em seu modelo.

Uma prática curricular consistente somente pode ser encontrada no saber dos sujeitos praticantes do currículo, sendo, portanto, sempre construída e reconstruída em todos os momentos. Elencado o objeto do conhecimento, é preciso que seja tratado por meio de um processo que considere a interação e mediação entre educador $\Leftrightarrow$ educando, como uma via de "mão dupla" em que as relações de ensinoaprendizagem ocorram dialeticamente. (CIEJA, 2008) ) $^{52}$

Desse modo, observamos na nova versão do Projeto CIEJA uma série de mecanismos para defesa da flexibilidade de tempo, currículo e organização do trabalho docente, visando

\footnotetext{
${ }^{52}$ Novo Projeto CIEJA - Documento não publicado, redigido coletivamente pelos gestores e professores dos CIEJAs, encaminhado e aprovado pelo CME em 2009, versão final fornecida pelo CIEJA Butantã.
} 
assegurar que os Centros possam, de fato, atender aos sujeitos que os procuram para concluir os estudos de maneira a democratizar não somente o acesso à educação, mas a concretização da educação democrática.

Além da flexibilidade do currículo compor a reordenação dos tempos, também refletiria na utilização dos espaços educativos, não apenas escolares, mas também extraescolares.

É relevante destacarmos, nesse sentido, que até a produção de nossa dissertação, os dois Centros enfocados permaneciam instalados em imóveis alugados, adaptados com várias reformas para o atendimento ao estudantes ao longo dos anos. Êda Luiz relatou que, na medida em que a procura pelo CIEJA crescia, articulava a construção de um "puxadinho aqui e ali". No CIEJA Butantã, as salas foram divididas e ampliadas.

Na prática, as casas possuem um aproveitamento peculiar do espaço, que se por um lado retrata os baixos investimentos em infraestrutura adequada, por outro, retratam que o espaço escolar incorpora características pedagógicas de seu uso.

A utilização dos espaços nos Centros obedece às necessidades e peculiaridades dos processos de ensino aprendizagem, não são prédios amplos e projetados para a grande circulação de pessoas, mas adaptados às necessidades de seus sujeitos, gerando também outra relação dos estudantes com a escola, de maior proximidade e cuidado coletivo.

A reflexão de Miguel Arroyo ratifica a importância da organização do tempo e espaço escolar atrelar-se ao desenvolvimento do trabalho pedagógico, não o oposto:

A organização de nosso trabalho é condicionada pela organização escolar que, por
sua vez, é inseparável da organização curricular. O que ensinamos, como ensinamos,
com que ordem, sequiência, lógicas e em que tempos e espaços são os condicionantes
de nossa docência, realizam-nos como profissionais ou limitam-nos e escravizam-nos
a cargas horárias, a duplicar turnos, a trabalhar com centenas de alunos por semana.
Sermos fiéis ao currículo, às competências que prioriza, às precedências e hierarquias
e a toda essa engrenagem montada em nosso trabalho tem estreita relação com os
conteúdos privilegiados e selecionados, sobretudo, com as lógicas em que indagações
sobre currículo estão organizados no currículo (ARROYO, 2007, p.19).

As imagens a seguir mostram que a configuração espacial dos centros Campo Limpo e Butantã resulta de uma concepção de educação popular própria das unidades. 


\section{Figura 4 - CIEJA Campo Limpo}

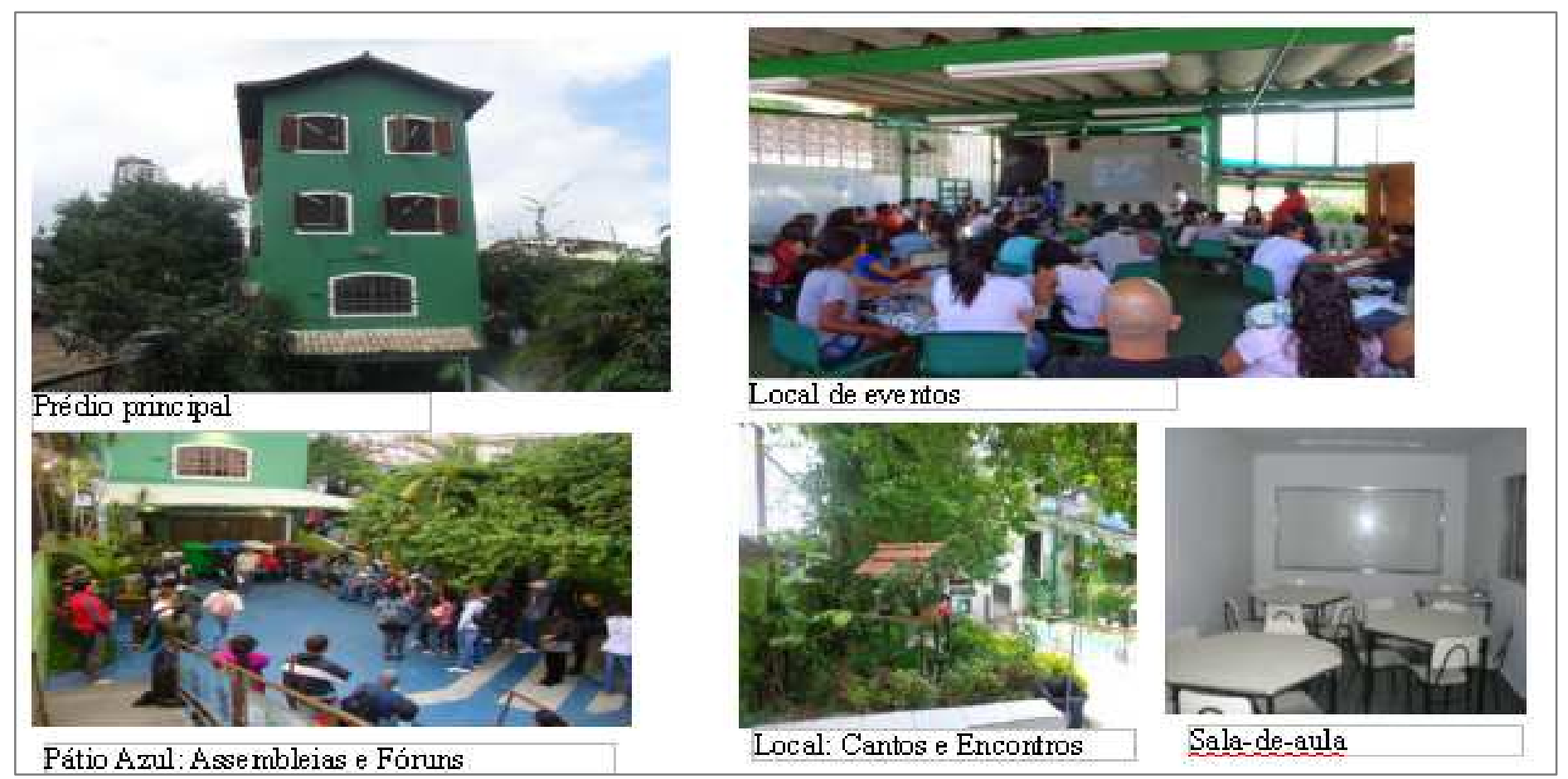

Fonte: Blog do CIEJA Campo Limpo.

Figura 5- CIEJA Butantã

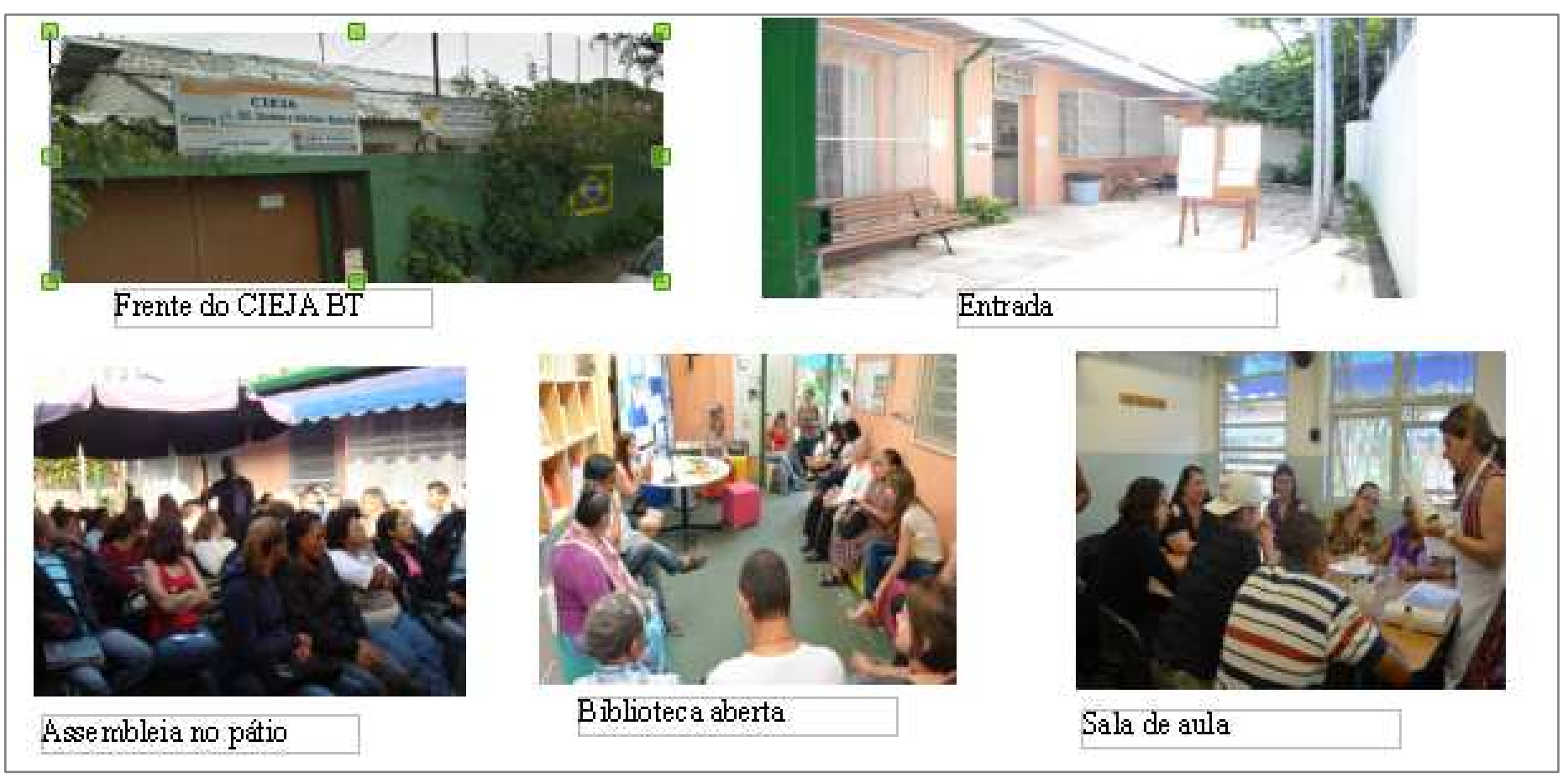

Fonte: Imagens fornecidas pela Coordenação Geral do CIEJA Butantã 
As salas de aula, por exemplo, na primeira unidade recebem como mobiliário, as mesas sextavadas ou grandes para que os estudantes se sentem em grupo, reiterando a importância da mediação do saber individual com o saber do outro, do diálogo, como explicitou Êda Luiz, Coordenadora Geral da unidade.

No Butantã, esse fato se repete na maioria das salas, restando algumas que utilizam as carteiras individuais também em disposição diferente daquela tradicional nas salas de aula das escolas: em semi-círculos, os estudantes sentam-se de modo a privilegiar o diálogo e sua integração.

O Pátio Azul no CIEJA Campo Limpo também demarca território de diálogo e participação democrática, é onde os estudantes vão às assembléias e atividades que visam alcançar mais estudantes. Do mesmo modo, o pequeno pátio do CIEJA Butantã ganha novos contornos nos dias de assembléia, enfileirando os bancos de madeira dispostos usualmente de maneira espaçada pelo local, propiciando os encontros e conversas dos estudantes enquanto não começam as aulas.

Destaca-se também a importância que os espaços demonstram às áreas de convívio social, como demonstra o denominado "Cantos e Encontros" no CIEJA Campo Limpo, ou as mesas sobre guarda-sol no Butantã. Os lugares apontam a concepção de que a vinculação dos estudantes à escola atrela-se à sua vinculação às pessoas, ao ambiente acolhedor que propiciam.

Nos dois centros, os quadros de avisos, murais e meios diversos de comunicação são dispostos de modo a atingir o estudante, mas também acolher suas produções. No CIEJA Campo Limpo, muros externos estão grafitados com frases e imagens dos próprios alunos, favorecendo sua identidade com o espaço.

No Butantã, mosaicos realizados pelos educandos com necessidades educacionais especiais colorem e dão identidade às salas. Há também uma biblioteca adaptada no corredor de passagem, visando aproximar os livros do cotidiano. Dispostos em casulos abertos, disponíveis para quem interessar, bastando assinar nome e data de empréstimo, os jovens, adultos e idosos podem acessá-los mais livremente, mesmo que apenas para folheá-los nos "puffs" e cadeiras ali presentes.

Dessa forma, destacam-se cuidado com as áreas de convivência e investimento das gestões locais para o melhor acolhimento dos estudantes, os arranjos para acessibilidade das 
pessoas com necessidades especiais, a demarcação de espaços para promoção da gestão democrática.

Nas unidades, os espaços de aprendizado e de aula extrapolam as salas fechadas, permeiam os corredores, pátios, jardins, hortas e expandem-se à rua, ao bairro, à cidade, uma vez que atividades em museus, teatros, associações comunitárias, centros de lazer, pontos históricos, entre outros, integram os currículos. Nesse sentido, esses lugares são cenários da construção do conhecimento e cidadania, de ampliação do sentido de pertencimento daqueles que, tantas vezes excluídos, passam ocupar os espaços e interagir com eles.

Concluímos que quanto à organização do modelo escolar dos CIEJAs ao longo dos anos, há uma tensão entre a vivência dos sujeitos dos centros e a tradição escolar. Persiste o conflito entre a pretensão de desenvolver lógicas inovadoras de articulação entre tempo, currículo, espaço, formação docente e a organização administrativa da rede municipal de ensino, que tende a estender a uniformização do calendário escolar, períodos e atribuição de aulas aos Centros.

Nesse sentido, a dissolução dessa tensão acabava gerando a reavaliação do modelo dos Centros, que ora buscavam se adaptar, ora lutavam para manter a coerência entre seu modelo, propósitos de criação e atendimento específico a jovens, adultos e idosos.

Quanto às concepções pedagógicas e organização curricular, apontamos que a hibridização de conceitos é comum em diferentes documentos dos Centros, bem como nos documentos de referência para organização escolar em âmbito nacional. Os próprios Parâmetros Curriculares Nacionais (PCNs) tratam da interdisciplinaridade como complementar ao ensino por competência, reafirmando um sentido de educação ao longo da vida que guarda o compromisso pela participação democrática e transformação social, através da formação de estudantes críticos e reflexivos.

Muito embora os discursos possam convergir, eles dão margem à redução do currículo escolar aos interesses do mercado capitalista, sem considerar o trabalho numa perspectiva mais ampla de fundamentação das relações sociais e, portanto, da cultura.

Desse modo, embora a flexibilidade seja a tônica dos CIEJAs, a construção dos currículos escolares ainda é lugar de luta entre diferentes projetos político-pedagógicos. Luta essa que se faz diariamente pelos sujeitos que constituem cada um dos 14 Centros na cidade 


\section{CONSIDERAÇÕES FINAIS}

Iniciamos nossa pesquisa com a reafirmação de que as lutas pela concretização dos direitos de jovens e adultos à educação são históricas, mas ponderamos que as leis por si mesmas não bastam, necessitam ser traduzidas em políticas públicas efetivas.

Apesar dos elevados índices de pessoas com quinze anos ou mais analfabetas ou sem escolaridade básica, vimos que conforme a tendência de todo o Estado de São Paulo, as matrículas de EJA na capital paulista vem decrescendo progressivamente durante as últimas décadas (1992-2012). Esse fato espelha o papel secundário que essa modalidade de ensino ocupa entre as políticas educacionais, num cenário de racionalização dos gastos públicos e redefinição do papel do Estado na provisão dos serviços sociais básicos.

Analisamos, ainda, que para além da democratização do acesso às oportunidades educativas, é desafiadora a constituição de modelos de ensino mais adequados às especificidades dos jovens, adultos e idosos dos grupos sociais de baixa renda e escolaridade para garantir melhores condições de permanência e continuidade nos estudos.

Apontamos que a descontinuidade das políticas públicas para a modalidade de ensino na cidade de São Paulo reflete as variadas concepções de EJA que nortearam os modelos de organização escolar ao longo dos anos. Os sujeitos que compõem e implementam essas políticas estão emersos numa crise discursiva, segundo o que Dagnino (2004) nomeia como "confluência perversa". Servindo-se de termos comuns como "democratização", "participação", "qualidade de ensino" e "flexibilidade", justificam e implementam ações diversas, cujo sentido pode ser até mesmo contraditório.

Ao lado de modelos tradicionais de ensino, emergiram propostas educativas diferenciadas que apontam para um novo paradigma nos modos de fazer a EJA, em modelos mais flexíveis e que se norteariam pelas peculiaridades dos estudantes tal como o CIEJA, que sobreviveu de 2001 a 2009 até ter suas diretrizes regulamentadas por lei em 2012. Esses fatores nos levaram a pesquisar como foi construído o Projeto CIEJA ao longo dos anos. O Modelo de Múltiplos Fluxos de Kingdon (2003) foi uma importante ferramenta de análise sobre sua constituição, que sofreu modificações constantes nos momentos em que a EJA entrava na agenda política educacional, marcadamente, no período de transição dos governos.

Subsidiados pelo Modelo de Kingdon (2003), avaliamos que a construção da política de EJA no interior da agenda educacional na cidade de São Paulo no período analisado foi 
feita através da seleção dos problemas a serem tratados e a escolha de suas soluções, dependendo do cenário político mais amplo, do posicionamento dos empreendedores e das comunidades políticas que intervieram no processo (partidos políticos posicionados no governo, técnicos de carreira, sindicatos docentes, movimentos e ONGs de educação popular, serviços paraestatais de qualificação profissional, dentre outros).

Avaliamos que a constituição das políticas não é linear ou, ou seja, o levantamento de problemas, a escolha de soluções, a implantação da política e sua avaliação não são ações propriamente sequenciais, podendo desenvolver-se independentemente. A confluência entre o fluxo dos problemas, das soluções e da política abriu as "janelas de oportunidade" para formulação das propostas e modificações nos CIEJAs.

Analisamos que a cada governo que assumia a cidade de São Paulo, problemas crônicos da EJA integravam a agenda decisional: os elevados contingentes de analfabetos e a baixa escolaridade média da população, os indicadores negativos sobre matrículas, aprovação, reprovação e evasão dos estudantes nessa modalidade de ensino, além do perfil dos educandos, repondo constantemente as necessidades de formação dos trabalhadores.

A existência de determinado conjunto de soluções precondicionava o reconhecimento público dos problemas recorrentes da EJA, isto é, os governos primeiro selecionavam as ideias a serem implantadas para depois recolocarem a modalidade de ensino em foco entre $2001 \mathrm{e}$ 2009.

Isso aponta a importância do fluxo da política na montagem da agenda decisional. Conforme os governos necessitam incorporar as reivindicações de determinados grupos e selecionam as soluções entre aquelas então disponíveis, escolhem os problemas que são prioridade. É, portanto, um processo conflitante, permeado pela atuação de diferentes grupos de interesse, que entraram em jogo na definição da agenda política e, por conseguinte, influenciaram o desenho dos CIEJAs.

Dessa maneira, observar como foram formuladas as soluções e recepcionadas pelos educadores nos forneceu pistas importantes sobre a constituição do modelo dos Centros. Para compreendermos o jogo de maior ou menor adesão dos sujeitos a elas, comparamos os discursos dos documentos que apresentavam os CIEJAs e os discursos das entrevistadas.

Daí que nos tenha sido caro o pensamento de Bourdieu (2008) sobre a constituição da legitimidade dos discursos, que implica uma forma de dominação de um indivíduo e suas ideias ou as de um grupo sobre as demais. Ela provém tanto da dominação e autoridade que 
esse grupo recebe no mercado linguístico, estreitamente ligado à estrutura social, como do uso linguístico de termos com valor mais ou menos reconhecidos pelos seus interlocutores, tais como "democratização do acesso à educação", "participação", "autonomia", "flexibilidade".

Destacamos que entre 1989 e 1992, as propostas de ensino municipal foram redirecionadas tanto em relação à estrutura da rede escolar e às parcerias com as organizações não governamentais (com a implantação do MOVA e transição do Programa EDA da Secretaria do Bem Estar Social para SME), como em relação à reorganização curricular e pedagógica.

É também nesse período que observamos dois fatores destoantes na constituição das políticas de EJA em relação àquelas dos vinte anos subsequentes: o primeiro é que a EJA figurava como uma das prioridades da educação na cidade, o segundo é que as soluções foram constituídas conjuntamente entre os decisores políticos e as comunidades políticas, não apenas "transplantadas" de um âmbito a outro.

Isso se verificou tanto no que concerne à estruturação do MOVA, em constante diálogo com as organizações não governamentais, como no que se refere à transição do Programa EDA da SEBES para SME, em que os educadores participaram das formações para o magistério e da constituição das novas propostas para modalidade EJA. Já nas EMPSGs, foi um período em as próprias unidades de ensino necessitavam identificar seus problemas e propor mudanças em diálogo com os educadores e educandos. Desse diálogo, floresceram diferentes soluções para EJA articuladas nos "Projetos Especiais de EJA", que variavelmente previam a rearticulação do tempo, reorganização do trabalho docente e flexibilização do currículo.

O desenho das soluções com participação ativa dos sujeitos que Kingdon (2003) designa de "atores invisíveis", ou seja, com os sujeitos "da ponta", gestores e professores que executam as políticas nas unidades educacionais, também enfrentara desafios diversos, como vimos no capítulo 3. No entanto, o sentido dessa participação, fazendo emergir também dos professores e gestores escolares as soluções educacionais, seria caro para sua adesão às mudanças então propostas nas décadas seguintes. Conforme apontamos, as soluções desenhadas nos Projetos Especiais das EMPSGs seriam compiladas na formulação dos CEMES no final da gestão Erundina (PT).

Identificamos também que durante as gestões de Maluf e Pitta (1993-2000) na cidade de São Paulo, os documentos que apresentavam as propostas para EJA e os CEMES 
incorporavam pressupostos comuns do governo de Luíza Erundina (1989-1992), tais como "flexibilidade", "participação" e "autonomia", então assumindo diferentes sentidos pela coexistência com soluções de instrução programada individual e à distância.

Se o uso de termos comuns auxiliava de algum modo a SME, neste período, a conseguir adesão dos docentes e gestores que iriam compor os CEMES na cidade de São Paulo, na prática, os Centros arranjariam soluções diferenciadas para superar as dificuldades para manutenção da metodologia então adotada. Eles utilizariam o espaço de estudo docente para organizar modelos de atendimento e de avaliação mais aproximados das necessidades estudantis observadas cotidianamente. Assim, formaram-se as turmas para realização de oficinas de alfabetização, artes ou outras em grupos-salas e foram renovados os sentidos de "flexibilidade" e "autonomia". Os arranjos dos educadores dos CEMES para ressignificar o trabalho pedagógico com os estudantes abriria espaço favorável às mudanças propostas pelo governo seguinte.

Vimos que, na idealização dos CIEJAs entre 2001 e 2004, as soluções adotadas remontavam às experiências dos CEMES desde o governo de Luíza Erundina (1989-1992), com Paulo Freire à frente da Secretaria Municipal de Educação (1989-1991), devido à afinidade política e ideológica de técnicos educacionais servidores municipais e acadêmicos que participaram da primeira gestão petista na cidade e que ocupariam cargos de decisão na gestão de Marta Suplicy (2001-2004). Respondiam também às pressões de diferentes grupos para reestruturação do MOVA e revisão do CEMES.

No que tange à seleção das soluções para EJA no governo de Marta Suplicy, vimos que ao lado daquelas resgatadas da gestão Erundina, mais afeitas ao paradigma da Educação Popular, encontravam-se também aquelas adotadas pelo SENAC-SP para qualificação profissional, baseadas na concepção de educação ao longo da vida. Como denotou a entrevista com Teresa Nori, o grupo do SENAC-SP também circundava os agentes de decisão política na gestão petista de 2001 a 2004.

O novo Projeto CIEJA buscaria, então, a integração entre a educação propedêutica e a formação profissional dos educandos, num cenário de altas taxas de desemprego e baixa escolaridade das pessoas com quinze anos ou mais no município.

Essas soluções foram adotadas no meio do caminho de implementação do Projeto e das políticas para EJA na cidade, como ocorrera na implantação dos CIEJAs (2001 - 2004) e na Reorganização da EJA entre 2006 e 2008. 
Além dos evidentes problemas relacionados ao investimento e infraestrutura dos Centros para realização dos Itinerários Formativos do SENAC- SP, ficou latente um conflito político tanto entre os servidores da DOT-SME e os técnicos do SENAC, quanto deles com os educadores dos CEMES - CIEJAs. As falas das educadoras dos CIEJAs confirmam que no início da avaliação dos CEMES houve várias reuniões dos Grupos de Trabalho (GTs) para elaborar as propostas do projeto dos novos Centros, mas questionam, por exemplo, a chegada dos Itinerários Formativos nas unidades. Expressões como "chegou pronto", de Célia Borges, foram recorrentes nas entrevistas e apontam a carência de diálogo entre as soluções já adotadas por SME para a formação profissional nos CIEJAs no início do governo Marta (2001) e a expectativa dos educadores em participar ativamente da constituição do currículo profissionalizante.

Também em relação ao próprio Projeto CIEJA, tal como seria implantado em 2003, observamos na fala dos educadores dos Centros certa restrição em relação à sua participação mais ampla, uma vez que os docentes então designados nos CEMES perderam suas designações e tiveram que passar por outro processo seletivo. Em algumas unidades, as equipes foram quase completamente reconfiguradas, como é o caso da unidade de Ermelino Matarazzo, em que $90 \%$ dos professores seriam novos em relação ao quadro anterior.

Isso conota a necessidade da SME, naquele período, de constituir um "novo" quadro de servidores para os Centros. Por um lado, respondia às pressões dos sindicatos pela transparência na constituição das equipes dos CIEJAs, por outro servia para compô-los com membros mais afeitos às novas propostas, em detrimento de constituí-las com o quadro de docentes já existente.

Concluímos desses fatores que, tendo sido delineado o problema dos CEMES e já prédeterminadas as propostas do modelo dos CIEJAs, os professores e gestores influenciaram mais na adesão ou bloqueio das soluções a serem implantadas no projeto, que na idealização das mesmas.

Observa-se que em alguns CIEJAs houve maior permanência de professores dos antigos CEMES, sendo que no Mandaqui e Jardim Adhemar de Barros (que viria a ser o CIEJA Butantã), respectivamente, 42,4\% e 53,8\% estavam nos Centros havia de 2 a 3 anos. Já no Jardim Consórcio, cerca de 33\% dos entrevistados tinham em média mais de 5 anos de experiência na unidade. (DOT-EJA, SENAC-SP, 2002, p.9).

A permanência desse grupo de professores, ainda que minoritário, na transição entre 
CEMES e CIEJAs é significativa se considerarmos as suas vivências, seus conhecimentos sobre suas comunidades escolares e a formação profissional continuada nas unidades.

A organização do tempo de trabalho docente, que garantia período de estudo e discussão dos professores nos Centros, fazia com que as soluções propostas no modelo CIEJA fossem constantemente analisadas pelos educadores e recebessem seu "feed-back". Além disso, os gestores e professores dos CEMES se organizariam como um coletivo nas reuniões do GT e, informalmente, para além delas. De fato, o grupo de gestores e docentes que permaneceu nos Centros passaria a atuar ativamente na formação do GT, repudiando, inclusive, a proposta inicial de SME: anexar os CIEJAs às EMEFs, desconstituindo seus espaços e atrelando a gestão dos projetos às direções das unidades escolares.

Observamos ainda que entre as premissas que integravam os documentos do Projeto CIEJA, entre 2001 e 2004, permanecem no discurso das entrevistadas: a gestão democrática das unidades de ensino, o desenvolvimento da autonomia estudantil, a flexibilidade do currículo e tempos de aula, e a importância de considerar os conhecimentos prévios e condições de vida dos educandos. Ou seja, são as premissas incorporadas na primeira gestão petista na cidade que mais ecoaram nas entrevistas dos gestores e docentes para caracterização dos Centros.

Já as soluções que tangenciavam a formação profissional e o currículo por competências, embora sejam integradas aos documentos oficiais que norteiam o funcionamento dos CIEJAs e também apareçam na fala das entrevistadas, não surgem em seus discursos para caracterizar o Projeto. Seja porque as experiências dos Centros em implantar os itinerários de formação profissional tenha sido, majoritariamente, precária, seja porque os discursos do SENAC- SP tenham obtido pouca adesão entre os docentes e gestores dos Centros.

Portanto, a incorporação dos discursos ou soluções de SME no modelo dos CIEJAs é bastante vinculada à atuação dos sujeitos "invisíveis" na agenda decisional, que concretizam as políticas. São esses sujeitos que resguardariam determinadas características do modelo CIEJA na gestão seguinte.

Observamos que as soluções para EJA na cidade durante o governo de Serra-Kassab (2005-2009) seriam norteadas por algumas experiências dos CIEJAs e de seus profissionais. Nesse período, os gestores dos Centros também foram chamados a compor um GT para Reorientação da modalidade de ensino na cidade, mas como vimos deixaram de ser 
convidados em determinado momento em que teria sido prevista a desconstituição dos CIEJAs para aplicação de parte de seu modelo às EMEFs.

Uma visão simplista sobre os Centros teria sido expandida à rede sem considerar elementos essenciais para o seu funcionamento, tais como: o horário coletivo dos docentes para planejamento e organização do currículo e projetos educativos; a estabilidade da equipe gestora e docente devido sua designação; a variedade de horários disponíveis aos estudantes para frequentarem ou repor aulas; a gestão democrática dos Centros, pautada no diálogo com a comunidade escolar e no atendimento às necessidades estudantis. Também se deixava de lado, novamente, a qualificação profissional dos educandos, então reduzidas aos Itinerários Formativos de Informática e às parcerias que as próprias unidades educacionais viessem a fazer.

Além desses elementos, verificamos a dificuldade de transferir o modelo CIEJA à rede, sem considerar as diferentes culturas escolares nos Centros e EMEFs no que se refere ao atendimento aos educandos. Nos CIEJAs havia três turnos de funcionamento, secretaria aberta ao atendimento estudantil no período de funcionamento da unidade, matrículas abertas durante o ano todo, aproveitamento de estudos dos ingressantes, atribuição de aulas diferenciada, por exemplo. Nas EMEFs verificavam-se a oferta da EJA apenas no período noturno, o funcionamento das secretarias e instâncias administrativas em horários restritos, a execução de matrículas também em períodos específicos e limitados, a burocratização para inserção do educando em determinado estágio de aprendizagem, professores que complementavam pouca carga horária no período noturno.

Esses fatores também impactariam de modo negativo na adesão dos professores da rede à proposta de Reorganização da EJA neste período, mas fortaleceria o modelo dos CIEJAs preservando a necessidade de manter uma estrutura própria e alternativa de atendimento aos jovens, adultos e idosos.

Êda Luiz, do CIEJA Campo Limpo articularia os gestores e professores dos CIEJAs, resistindo à possibilidade de encerramento dos CIEJAs, organizando manifestações, reunindo as comunidades escolares diante do Secretário Municipal Alexandre Schneider, sendo desafiada a escrever o novo projeto para os Centros.

Nesse momento, as soluções propostas para os CIEJAs seriam então desenhadas pelos sujeitos das próprias unidades de ensino, permanecendo em seu modelo as características que assegurariam a continuidade do trabalho que já se desenvolvia nelas. 
É importante observarmos que o primeiro Projeto CIEJA possuía diretrizes mais abertas, formulados majoritariamente por SME, com respeito à autonomia dos Centros, para alcançar maior adesão das soluções e para acolher a diversidade das unidades e seus arranjos organizacionais. Já o Novo Projeto CIEJA "amarrava" alguns pontos frequentemente questionados por SME e CME em diretrizes mais restritas, para ao mesmo tempo resguardar seu modelo de funcionamento e responder às demandas dos técnicos educacionais da SME, buscando sua adesão.

Entre o primeiro Projeto CIEJA e o Novo Projeto CIEJA na cidade, bem como reafirmaram as educadoras entrevistadas, verificamos poucas mudanças, as principais correspondem à redução dos Itinerários Formativos de qualificação profissional, ao rearranjo da carga horária por disciplinas, à atribuição de aulas aos docentes e organização de seu horário de trabalho coletivo.

O horário coletivo seria constantemente questionado durante o funcionamento dos CIEJAs, justamente pela percepção de que manter um período destinado ao estudo e planejamento que reunisse todo o corpo docente seria como uma espécie de "privilégio" dos Centros em relação às demais unidades de ensino e inviabilizaria o atendimento dos estudantes em horários fixos.

No entanto, como relata a entrevistada Célia Borges (CIEJA Butantã) para constituir um projeto diferenciado, com reordenação do currículo e práticas pedagógicas era preciso "ser diferente", ou seja, destinar ao coletivo de educadores das unidades um tempo adequado de formação e planejamento. Além disso, a flexibilidade de horários, própria dos CIEJAs, favoreceria que as atividades fossem distribuídas em horários alternativos, garantindo o atendimento aos estudantes.

Concluímos, portanto, que o Projeto CIEJA nasceu de soluções propostas para EJA desde a gestão de Luíza Erundina (1989-1993), que conferiram um sentido de flexibilidade às práticas educativas nos Centros, atendendo as peculiaridades dos estudantes, incentivando sua participação e autonomia. Essas soluções, associadas às propostas do SENAC-SP, seriam tanto mais consolidadas, quanto mais adesão tivessem dos gestores e educadores dos Centros.

Esse jogo de adesão ou bloqueio de soluções educacionais propostas por diferentes governos, bem como sua experimentação nos Centros favoreceu que o corpo docente dos CIEJAs e seus gestores guardassem o conhecimento sobre a própria prática, determinado "know-how", que os posicionou não apenas como expectadores ou executores das políticas de 
EJA, mas empreendedores políticos. O Novo Projeto CIEJA carrega, portanto, a marca das vivências educativas nos Centros e a regulação dos CIEJAs em lei revelam a possibilidade da constituição de políticas a partir das bases e por movimentação delas, conforme observamos.

Cabe destacar que o CME, ao avaliar o desenvolvimento das práticas nos Centros, provocava mudanças efetivas no seu funcionamento, pois solicitava que fossem cumpridos os pressupostos do Projeto CIEJA de integrar a escolarização básica e a formação profissional, e efetivados os dias letivos e carga horária para EJA estabelecidos em regulação nacional e estadual. Caberia à Diretoria de Orientações Técnicas empreender ações que atendessem a essas necessidades sem que isso significasse as recorrentes tentativas de uniformização dos sistemas de atribuição de aulas e dias letivos entre os CIEJAs e as EMEFs ou colocasse em risco a sobrevivência dos Centros como alternativa diferenciada de atendimento aos jovens adultos e idosos, como de fato ocorreu. Também à DOT caberia a atuação mais crítica para evidenciar o descompasso entre a exigência de amplas cargas horárias nos cursos de EJA e os tempos disponíveis pelos estudantes, marcando que a burocratização excessiva das cargas horárias desconsidera os próprios tempos de aprendizagem dos jovens, adultos e idosos e, muitas vezes, bloqueia a continuidade de seus estudos.

Nesse sentido, o CME teve o papel de órgão regulador, que imprimia adaptações nos CIEJAs, mas era também espaço para avaliar e garantir a promoção da educação com qualidade, espaço que deveria ser mais amplamente ocupado e aproximado da realidade dos Centros por meio dos técnicos de DOT.

Desse modo, os "sujeitos invisíveis" são de extrema importância para seleção e sobrevivência das propostas educativas. O delineamento dessas propostas em conjunto com as escolas é, assim, fundamental para concretização das políticas e continuidade entre diferentes governos.

A educação proporciona mudanças efetivas na vida dos jovens, adultos e idosos, propicia a participação dos estudantes na esfera do trabalho e da cultura de modo mais abrangente e justo. Concretizar o direito à educação para a parcela da população exige reconhecer sua diversidade e implementar lógicas organizacionais que não reproduzam a escola regular, mas articule modelos educativos adequados à sua realidade.

Entre a mão esquerda e direita de Miró (LIMA, 2005), a concepção de educação ao longo da vida e "flexibilidade" que nortearam o modelo CIEJA ao longo anos revelam a importância de reordenar tempos, espaços e currículo escolar, propiciando o diálogo entre os 
docentes, suas práticas e as demandas estudantis. Diversificação de horários e atividades educativas; interdisciplinaridade; orientações de estudos; reconhecimento de saberes estudantis; horário de planejamento coletivo docente; fortalecimento de espaços participativos foram elementos fundamentais para o desenho dos CIEJAs, que definiram maior sucesso na promoção do acesso e permanência de jovens, adultos e jovens no município.

Apontamos, no entanto, a necessidade dos CIEJAs e demais oportunidades educativas para EJA não somente articularem, mas integrarem a educação propedêutica e profissional, promovendo maiores possibilidades de qualificação e atuação dos educandos no mundo do trabalho. Se essa tarefa foi bastante desafiadora no início do Projeto, também apontou caminhos possíveis para ampliar o sentido da educação na vida dos estudantes: práticas que considerem os arranjos e desenvolvimentos locais, pautadas na sistematização e elevação dos saberes do trabalho e promoção de melhores condições de vida.

Consideramos que é através da gestão democrática da educação que se pode alcançar a maior adequação dos modelos escolares à realidade discente. Nossa análise é de que o diálogo constante das práticas educativas as suas expectativas e condições de vida estudantis é fortalecido em espaços participativos nas próprias unidades de ensino, mas deve abranger também as relações entre as escolas e as instâncias administrativas da rede municipal.

Em outras palavras, é necessário recuperar a radicalidade política da gestão democrática, tal como aponta Arroyo (2008), de modo que não se reduza à gestão rotineira e burocrática das unidades de ensino, mas se possibilite o desenho de políticas públicas inovadoras para EJA, em constante diálogo com a realidade das escolas.

A atuação dos gestores e professores dos CIEJAs na trajetória dos Centros reforça, portanto, a necessidade de ampliar o sentido político da gestão democrática, como apontou Arroyo (2005), de modo que participem ativamente das agendas decisionais, não como apenas como receptores, consultores ou executores das políticas, mas como fomentadores delas.

Foi o exercício da gestão democrática nos próprios CIEJAs que garantiu o diálogo das práticas educativas com as peculiaridades dos educandos, concedendo-lhes voz, inclusive, para clamarem mudanças e participarem politicamente, como no caso das mobilizações estudantis pela continuidade dos Centros ou pela implantação do Ensino Médio no mesmo modelo.

Nesse sentido, consideramos importante conferir relevo ao papel fundamental da formação dos professores e gestores, "sujeitos invisíveis" na constituição das políticas. O termo "sujeitos invisíveis" nos parece bastante pertinente quando observamos o desenho da 
agenda decisional, que tende a retirar ou minimizar sua participação na definição das soluções e políticas educacionais.

Nóvoa (2012) chama atenção para "a ilusão da racionalização do ensino, da pedagogia por objetivos, do esforço para prever, planificar, controlar". Concordamos com a afirmação do autor de que a atuação de diferentes especialistas na formação de professores por um lado traz enriquecimento ao campo, por outro marginaliza os docentes, reduzindo seu papel de reflexão, decisão e ação. Seria preciso, portanto, uma formação docente horizontal, que devolvesse a formação em serviço aos professores, uma autoformação que valorizasse o conhecimento docente, criasse uma nova realidade organizacional e reforçasse o espaço público da educação (NÓVOA, 2012).

Ressaltamos, no entanto, que a vivência das entrevistadas na rede e nas formações docentes durante a gestão Erundina (1989-1992), nos GTs para implantação dos CIEJAs (gestão de Marta Suplicy- 2001-2004) e nos horários coletivos das unidades reverberou nos anos seguintes, configurando determinada identidade de suas práticas e percepções sobre a trajetória dos Centros.

Consideramos que a existência do Horário Coletivo nos CIEJAs garantiu não apenas a organização de práticas pedagógicas reflexivas, como fortaleceu gestores e professores para apresentarem ou resguardarem as características do modelo CIEJA que consideravam mais importantes frente a questionamentos diversos. Seria, portanto, um espaço fundamental para implementação das políticas. Conforme, Nóvoa:

Nada será conseguido se não se alterarem as condições existentes nas escolas e as
políticas públicas em relação aos professores. É inútil apelar à reflexão se não houver
uma organização das escolas que a facilite. É inútil reivindicar uma formação mútua,
interpares, colaborativa, se a definição das carreiras docentes não for coerente com
esse propósito. (NÓVOA, 2012, p.18)

A organização de um modelo escolar que privilegiava a formação e atuação docente em constante reflexão para atendimento às demandas estudantis, fomentou a constituição de um grupo de gestores e professores que passou a deter o conhecimento e experiência sobre as soluções educacionais adequadas à sua realidade. Foi também a formação de uma rede entre esses sujeitos dos CIEJAs que propiciou, como vimos, não apenas a continuidade dos Centros durante diferentes governos, mas a sua institucionalização em lei em 2012.

Concluímos, assim, que a medida em que o princípio da gestão democrática da educação permeie desde as práticas escolares até o desenho das políticas públicas, elas se aproximarão dos jovens, adultos e idosos que voltam aos bancos escolares como sujeitos de 
direitos, sujeitos concretos, com necessidades e interesses diversos, sujeitos do tempo presente, da vida presente.

Nesse sentido, as políticas públicas de EJA necessitam considerar os sujeitos que se sentam nos bancos escolares e aqueles que se encontram cotidianamente com eles para ensinar e aprender, não podem se afastar deles ou reduzir sua participação, sob pena de idealizar a educação para um futuro que não chega, em vez de promover a todos a educação ao longo da vida. 


\section{REFERÊNCIAS BIBLIOGRÁFICAS}

ABBONíZIO, Aline Cristina de Oliveira.Orientações da parceria entre poder público e organizações sociais no MOVA-SP. 2007. Dissertação (Mestrado em Educação) - Faculdade de Educação, Universidade de São Paulo, São Paulo, 2007. Disponível em: <http://www.teses.usp.br/teses/disponiveis/48/48134/tde-09102007-093437/>. Acesso em: 16 out. 2011.

ABRAMO, Helena Wendel et al. Pesquisa Agenda Juventude Brasil: pesquisa nacional sobre o perfil e opinião dos jovens brasileiros 2013. Brasília: SNJ, 2013. 116 p.

ABRAMOVAY, Miriam; ANDRADE, Eliane Ribeiro; ESTEVES, Luiz Carlos Gil (Orgs). Juventudes: outros olhares sobre a diversidade. Brasília: Ministério da Educação, Secretaria de Educação Continuada, Alfabetização e Diversidade; UNESCO, 2007.

ALVES, ROSILENE MORAES. Comunicação, educação e consumo: a circulação de práticas de consumo na intraficção e a sua apropriação por estudantes. 2012. Dissertação (Mestrado em Comunicação e Práticas de Consumo) - Escola Superior de Propaganda e Marketing, São Paulo, 2012. Disponível em: <http://www2.espm.br/banco-dedissertacoes/defesas-em-2012>. Acesso em: 03 set. 2013.

ALVES, Mariana Gaio. Aprendizagem ao longo da vida: entre a novidade e a reprodução de velhas desigualdades. Revista Portuguesa de Educação, v. 23, n. 1, p. 7-28, 2010.

ARROYO, M. G. Educação de jovens e adultos: um campo de direitos e de responsabilidade pública. IN: SOARES, Leôncio José Gomes; GIOVANETTI Maria Amélia; Gomes, Nilma Lino (Orgs.).Diálogos na educação de jovens e adultos. Belo Horizonte: Autêntica, 2005. p. 19-50.

Indagações sobre currículo: educandos e educadores: seus direitos e o currículo. Brasília: Ministério da Educação, Secretaria de Educação Básica, 2007.

Gestão Democrática: recuperar sua radicalidade política? In: CORREA, B. C.; GARCIA, T. O. (Orgs.). Políticas Educacionais e organização do trabalho na escola. São Paulo: Xamã, 2008. p. 39-56.

BARRETO, Vera; CARLOS, José. Dois alfabetizadores antes do golpe de 64. 1992. (mimeo.)

BARROSO, João. A utilização do conhecimento em política: O caso da gestão escolar em Portugal. Educação e Sociedade. Campinas, vol. 30, n. 109, p. 987-1007, set./dez. 2009. Disponível em <http://www.cedes.unicamp.br> Acesso em: 17 ago. 2012

BEISIEGEL, C. R. Estado e Educação Popular. Um estudo sobre a educação de adultos. São Paulo: Livraria Pioneira Editora, 1974.

. Política e Educação Popular (A teoria e a prática de Paulo Freire no Brasil). $3^{\text {a }}$. ed. São Paulo: Ática, 1982. 
Considerações sobre a política da União para a educação de jovens e adultos analfabetos. Revista Brasileira de Educação, São Paulo, jan./abr. 1997, nº 4, p. 26-34.

BOURDIEU, Pierre. A economia das trocas linguiísticas. São Paulo: Edusp, 2008.

BRANDÃO, C.R. Educação popular. São Paulo: Brasiliense, 1984.

BRITTO, L. P. L. Educação de adultos trabalhadores na sociedade industrial. In: Contra o consenso: cultura escrita, educação e participação. Campinas: Mercado de Letras, 2003, p. 195-209.

CAPELLA, Ana Cláudia Niedhardt. Perspectivas teóricas sobre o processo de formulação de políticas públicas. Revista Brasileira de Informação Bibliográfica em Ciências Sociais BIB, 2006, n.61, p. 25-52.

CAMARGO, Ruth Aurora da Silveira. A alfabetização de jovens e adultos no Município de São Paulo na gestão da Prefeita Luíza Erundina de Sousa(1989-1992). Dissertação (Mestrado em Educação, Supervisão e Currículo) - Pontifícia Universidade Católica de São Paulo, São Paulo, 1996.

CARRANO, Paulo. Educação de Jovens e Adultos e Juventude: o desafio de compreender os sentidos da presença dos jovens na escola da "segunda chance". Revista de Educação de Jovens e Adultos, v. 1, p. 55-67, 2007.

CARVALHO, Marília Pinto de. Sucesso e fracasso escolar: uma questão de gênero. Educação e Pesquisa[online]. 2003, vol.29, n.1, pp. 185-193 Disponível em <http://dx.doi.org/10.1590/S1517-97022003000100013>. Acesso em: 21 out. 2011.

COUTINHO, Joana Aparecida. A participação popular na gestão da saúde de São Paulo. Lutas Sociais, São Paulo, v. 2, p. 125-140, 1997.

DAGNINO, Evelina. (2004). ¿Sociedade civil, participação e cidadania: de que estamos falando? In: MATO, Daniel (coord.), Políticas de ciudadanía y sociedad civil en tiempos de globalización. Caracas: FACES, Universidad Central de Venezuela, p. 95-110.

DI PIERRO, Maria Clara. Descentralização, focalização e parceria: uma análise das tendências nas políticas públicas de educação de jovens e adultos. Educação e Pesquisa, São Paulo, v.27, n.2, p.321-337, jul./dez. 2001

. Notas sobre a redefinição da identidade e das políticas públicas de educação de jovens e adultos no Brasil. Educação e Sociedade, Campinas, vol. 26, n. 92, p. 1115-1139, Especial 2005.

Luta social e reconhecimento jurídico do Direito Humano dos jovens e adultos à educação. Educação. Santa Maria, v. 33, n. 3, p. 395-410, set./dez. 2008.

; JOIA, Orlando; RIBEIRO, Vera Masagão. Visões da Educação de Jovens e Adultos no

Brasil. Cadernos Cedes, ano XXI, $\mathrm{n}^{\circ}$ 55, novembro/2001. Disponível em <http://www.scielo.br/pdf/ccedes/v21n55/5541.pdf $>$. Acesso em 29 set. 2011. 
; GALVÃO, Ana Maria de Oliveira. Preconceito contra o analfabeto. São Paulo: Cortez, 2007.

; XIMENES, Salomão Barros. Políticas e direitos educativos dos jovens e adultos no estado de São Paulo: notas de Pesquisa e relato de intervenção. Anais do $25^{\circ}$ Simpósio Brasileiro e $2^{\circ}$ Congresso Ibero-Americano de Política e Administração da Educação. São Paulo, 2011. São Paulo: ANPAE, 2011. CD-ROM.

DRUMMOND, Carlos de Andrade. Nosso tempo. In: A rosa do povo. Rio de Janeiro: Nova Aguilar, 1992, p.158-159

FELIPE, Glaucia Ribeiro. Na morada da diversidade: a tessitura teatral como instrumento democrático. 2010. Dissertação (Mestrado em Pedagogia do Teatro) - Escola de Comunicações e Artes, Universidade de São Paulo, São Paulo, 2010. Disponível em: <http://www.teses.usp.br/teses/disponiveis/27/27155/tde-19112010-114713/>. Acesso em: 20 set. 2013.

FROCHTENGARTEN, Fernando. Educação de adultos migrantes: a experiência de um professor nativo. Travessia, São Paulo, v. 56, p. 41-45, 2006.

FUNARI, Sueli. Caminhos da educação de adultos no município de São Paulo: o livro didático e a abordagem do texto literário. 2008. Dissertação (Mestrado em Educação) Faculdade de Educação, Universidade de São Paulo, São Paulo, 2008. Disponível em: <http://www.teses.usp.br/teses/disponiveis/48/48134/tde-09102008-145516/>. Acesso em: 08 ago. 2011

GADOTTI, Moacir. Escola cidadã, cidade educadora: projetos e práticas em processo. Da escola cidadã a cidade educadora: a experiência de Porto Alegre. Porto Alegre: Prefeitura Municipal de Porto Alegre, Secretaria Municipal de Educação, 2003.

Freire, 2009.

- Educação de Adultos como Direito. São Paulo: Editora e Livraria Instituto Paulo

GHANEM, Elie. Educação escolar e democracia no Brasil. São Paulo, 2000. Tese (Doutorado) - Faculdade de Educação, Universidade de São Paulo, São Paulo, 2000.

GÓES, Moacir. De pé no chão também se aprende a ler (1961-1964): uma escola democrática. Rio de Janeiro: Civilização Brasileira, 1980.

GRINKRAUT, Ananda; NAKAGAWA, Carolina; CAMPAGNUCCI, Fernanda; SILVA Uvanderson. Panorama das desigualdades na cidade de São Paulo. Em questão. São Paulo, n. 8, p. 25-114, 2013. $1^{\mathrm{a}}$ Edição.

HADDAD, Sérgio. (Coord.). Educação de jovens e adultos no Brasil (1986-1998). 2002 (Estado do Conhecimento, 8). Brasília: MEC/INEP/COMPED,

Novos Caminhos em educação de Jovens e Adultos - EJA: um estudo de ações do 
poder público em cidades de regiões metropolitanas brasileiras. São Paulo: Global Editora, 2007.

. Educação e exclusão no Brasil. Em Questão. São Paulo, v. 3, p.5, 2008. Publicado originalmente no jornal Le Monde Diplomatique Brasil Disponível em: <http://www.acaoeducativa.org.br> Acesso em: 12 set. 2012.

KINGDON, John. Agendas, alternatives and public policies. 2. ed. New York: Addison Wesley, 2003.

LIMA, Licínio C. Do aprender a ser à aquisição de competências para competir. In: Margem Esquerda. Ensaios marxistas. São Paulo: Boi Tempo, 2005.

Cidadania e educação: adaptação ao mercado competitivo ou participação na democratização da democracia. Educação, Sociedade \& Culturas, v. 23, p. 71-90, 2005.

.Políticas de Formação ao Longo da Vida. Formação Contínua e Qualidade da Escola. Actas do IX Congresso Nacional de Centros de Formação de Associações de Escolas Guimarães, 2007.

MOREIRA, Evaldo de Assis. Políticas públicas para a educação básica de jovens e adultos na Região Metropolitana de São Paulo - RMSP: o caso do ProJovem (2005-2007). 2009. Dissertação (Mestrado em Geografia Humana) - Faculdade de Filosofia, Letras e Ciências Humanas, Universidade de São Paulo, São Paulo, 2009. Disponível em: <http://www.teses.usp.br/teses/disponiveis/8/8136/tde-20082009-144320/>. Acesso em:3 out. 2012.

OLIVEIRA, Z. M. R. ; BAZZONI, C. ; CARVALHO, D. L. ; MARINO, D. ; Narciso Jr, Jorge; MELlO, A. M. ; AUGUSTO, S. ; CARDOSO, F. ; OLIVEIRA, J. M. R.; VITORIA, T. Desafios no planejamento curricular de programa de formação pedagógica de educadores de creches em curso normal de nível médio. Contrapontos (UNIVALI), v. 4, p. 43-56, 2004.

PACHECO, Reinaldo Tadeu Boscolo. O espetáculo da educação: os Centros Educacionais Unificados do Município de São Paulo como espaços públicos de lazer. 2009. Tese (Doutorado). Universidade de São Paulo, São Paulo, 2009.

PONTUAL, Pedro de Carvalho. Desafios pedagógicos na construção de uma relação de parceria entre movimentos populares e o governo municipal da cidade de São Paulo na gestão de Luiza Erundina: a experiência do MOVA - SP, 1989-1992. Dissertação (Mestrado em Educação)- Pontifícia Universidade Católica, São Paulo, 1996.

POCHMANN, Márcio. Educação e Trabalho: como desenvolver uma relação virtuosa? Educação e Sociedade, Campinas, vol. 25, n. 87, p. 383-399, maio/ago, 2005. Disponível em <http://www.cedes.unicamp.br>. Acesso em 08 set 2011.

POSSANI, Lourdes de Fátima Paschoaletto. Currículos emancipatórios para a educação de jovens e adultos na perspectiva das políticas públicas: resistências e esperanças. Dissertação (Doutorado)- Pontifícia Universidade Católica, São Paulo, 2008. 
RIBEIRO, Vera Masagão. A formação de educadores e a constituição da educação de jovens e adultos como campo pedagógico. Educação \& Sociedade, v. 20, n. 68, p. 184-201, 1999.

RODRIGUES, Thiago Donda. A Etnomatemática no contexto do ensino inclusivo:Possibilidades e Desafios. 2008. Dissertação (Mestrado em Educação Matemática) Instituto de Geociências e Ciências Exatas, Universidade Estadual Paulista Júlio de Mesquita Filho, 2008.

RUMMERT, Sonia Maria. A "marca social” da educação de jovens e adultos trabalhadores/The "social stamp" of the young and adults workers education. Trabalho \& Educação, v. 17, n. 3, p. 13-29, 2010. Disponível em: <http://www.portal.fae.ufmg.br/seer/index.php/trabedu/article/> Acesso em: 03 out. 2011.

SANTOMÉ, Jurjo Torres. A construção da escola pública como instituição democrática: poder e participação da comunidade. Currículo sem Fronteiras, v. 1, n. 1, p. 50-88, 2001.

SILVA, Rogério Bezerra da; DAGNINO, Renato. O enfoque de análise de políticas e a política pública do pólo e parque de alta tecnologia de Campinas. Revista. Sociologia e Política, Curitiba, v. 19, n. 40, Oct. 2011. Disponível em <http://www.scielo.br/scielo.php?script=sci_arttext\&pid=S010444782011000300013>.Acesso em 13 abr. 2012.

SOUZA, Celina. Políticas Públicas: uma revisão da literatura. Sociologias, Porto Alegre, ano $8, \quad \mathrm{n}^{\mathrm{o}} \quad 16, \quad \mathrm{jul} / \mathrm{dez} \quad 2006, \quad$ p. 20-45. Disponível em <http://www.scielo.br/pdf/soc/n16/a03n16.pdf $>$. Acesso em 13 abr. 2012

SPOSITO, Marília. et. al. Juventude, escolarização e poder local. Relatório da primeira fase da pesquisa: Políticas públicas de educação de jovens e adultos e Juventude na região metropolitana de São Paulo. São Paulo: Ação Educativa, 2005. Disponível em <www.bdae.org.br>. Acesso em 28 set. 2011

VENTURA, Jaqueline. Educação ao longo da vida e organismos internacionais: apontamentos para problematizar a função qualificadora da Educação de Jovens e Adultos.Revista Brasileira de Educação de Jovens e Adultos, Vol. 1, nº 1, 2013.

VIANA, Kety. As canções e filmes como recursos codificadores e descodificadores no currículo da EJA. 2011.Dissertação (Mestrado em Educação) - Instituição de Ensino: Pontifícia Universidade Católica de São Paulo. São Paulo, 2011.

VIEIRA, Rosilene Silva.As relações federativas e as políticas de EJA no Estado de São Paulo no período de 2003-2009. 2011. Dissertação (Mestrado em Educação) - Faculdade de Educação, Universidade de São Paulo, São Paulo, 2011. Disponível em: <http://www.teses.usp.br/teses/disponiveis/48/48134/tde-04102011-095459/>. Acesso em: 04 abr. 2008. 


\section{FONTES E DOCUMENTOS}

BRASIL. Constituição (1988). Constituição da República Federativa do Brasil. Brasília, DF: Senado, 1988. Disponível em: <https://www.planalto.gov.br/ccivil_03/Constituicao〉. Acesso em: 21 jun. 2011.

BRASIL. Lei de Diretrizes e Bases da Educação Nacional. Lei nº 9394. 20 de dezembro de 1996. Estabelece as diretrizes e bases da educação nacional.

BRASIL. Parecer 11/2000 (CNE/CEB). Diretrizes curriculares nacionais para a Educação de jovens e adultos. Brasília. DF; Congresso Nacional, 10 de maio de 2000.

FUNDAÇÃo SISTEMA ESTADUAL DE ANÁliSE DE DADOS (SEAD). Pesquisa de Emprego e Desemprego Região Metropolitana de São Paulo. BOLETIM ANUAL 2000. Disponível em: <http://www.seade.gov.br/produtos/ped/index.php> Acesso em: 12 mai. 2013.

Trabalho e Desigualdades de Gênero na Região Metropolitana de São Paulo.

Mulher e Trabalho. São Paulo, març. de 2010, no 21. Disponível em http://produtos.seade. gov.br/produtos/mulher/boletins/resumo_boletim_MuTrab21.pdf> Acesso em 12 mai. 2013

INSTITUTO BRASILEIRO DE GEOGRAFIA E ESTATÍSTICA. Síntese de Indicadores Sociais: Uma Análise das Condições de Vida da População Brasileira 2010. Rio de Janeiro: IBGE, 2010.

MARE. Plano diretor da reforma do aparelho do Estado. Documento da Presidência da República: Câmara da Reforma do Estado. Versão 9.8.95. Brasília: 1995.

SINPEEM. Jornal do SINPEEM. São Paulo. Setembro de 2008, ano 12, № 103.

Jornal do SINPEEM. São Paulo. Dezembro de 2008, ano 12, Nº 104.

PREFEITURA DE SÃO PAULO. DECRETO No 35.134, DE 17 DE MAIO DE 1.995 Institui o Programa de Gestão da Qualidade Total na Administração Pública Direta e Indireta no Município de São Paulo e dá outras providências.

. DECRETO No 43.052, DE 4 DE ABRIL DE 2003. Cria os Centros Integrados de Educação de Jovens e Adultos - CIEJAs.

. LEI ORGÂNICA MUNICIPAL, de 4 de abril de 1990. Tribunal de Contas do Município de São Paulo. Disponível <http://www.tcm.sp.gov.br/legislacao/lomun/lom_t1.htm> Acesso em: 10 set. 2011.

Conselho Municipal de Educação. Parecer CME n 105/07 - CEB - Aprovado em 13/12/07. Diretoria de Orientação Técnica da Educação de Jovens e Adultos da Secretaria 
Municipal de Educação (DOT/SME) Relatório de desenvolvimento do Projeto CIEJA em 2006

. Parecer CME n ${ }^{\circ}$ 81/06- CEB - Aprovado em 24/08/06. DOT-EJA da Secretaria Municipal de EducaçãoRelatório de desenvolvimento do Projeto CIEJA no ano de 2004.

Secretaria Municipal de Desenvolvimento Urbano. Departamento de estatística e produção de informação. Infocidade. Disponível em <http://infocidade. prefeitura.sp.gov.br>. Acesso em: 12 set. 2012

. Secretaria Municipal de Educação. CIEJA - Centro Integrado de Educação de Jovens e Adultos. Relatório de Pesquisa. Perfil do contexto dos Centros. São Paulo, 2002.

. Secretaria Municipal de Educação. CIEJA - Centro Integrado de Educação de Jovens e Adultos: Regimento escolar. São Paulo, 2003.

. Secretaria Municipal de Educação. Continuando a Conversa. Revista EducAção No 02, maio. 2002,

- Secretaria Municipal de Educação. Aos que fazem a educação conosco em São Paulo. DOM, 1989. Disponível em <acervo.paulofreire.org>. Acesso em: 21 jun. 2012.

- Secretaria Municipal de Educação. Cadernos de Formação - Reorientação Curricular do Ensino Noturno - Construindo um Novo Ensino Noturno: Sistematização dos Projetos elaborados pelas Escolas. Série: Construindo a Educação do Jovem e Adulto Trabalhador. Caderno 3, 1992.

Secretaria Municipal de Educação. Cadernos de Formação 2: Reorientação Do Ensino Noturno - Diretrizes Para Elaboração de Projetos Pelas Escolas. Série: Construindo a Educação do Jovem e Adulto Trabalhador- Caderno 2. São Paulo, 1991.

- Secretaria Municipal de Educação. Centro Municipal De Ensino Supletivo capacitação inicial. 1996.

- Secretaria Municipal de Educação. Diretoria de Orientações Técnicas. CIEJA Centro Integrado de Educação de Jovens e Adultos. Relatório de Implantação Currículo Integrado - Ensino Fundamental/EJA e Educação Profissional. São Paulo, março de 2003.

Secretaria Municipal de Educação. Diretoria de Orientações Técnicas. CIEJA Centro Integrado de Educação de Jovens e Adultos. Relatório de Pesquisa. Caracterização dos Professores. São Paulo, 2002.

Secretaria Municipal de Educação. Diretoria de Orientações Técnicas. CIEJA Centro Integrado de Educação de Jovens e Adultos. Relatório de Pesquisa. Condições atuais dos Centros. 2002

- Secretaria Municipal de Educação. Diretoria de Orientações Técnicas. CIEJA Centro Integrado de Educação de Jovens e Adultos: Plano de Curso. São Paulo, 2003.

- Secretaria Municipal de Educação. Diretoria de Orientações Técnicas CIEJA Centro Integrado de Educação de Jovens e Adultos: Projeto. São Paulo, 2002. 
. Secretaria Municipal de Educação. Diretoria de Orientações Técnicas. CIEJA Centro Integrado de Educação de Jovens e Adultos.Relatório de Pesquisa. Caracterização dos alunos. Dados gerais.São Paulo, 2002.

1992.

. Secretaria Municipal de Educação. Construindo a Educação Pública e Popular,

Secretaria Municipal de Educação. Contexto, Abril de 1994.

. Secretaria Municipal de Educação. Continuando a Conversa. Revista EducAção No 01, jan. 2001.

. Secretaria Municipal de Educação. Diretoria de Orientação Técnica. Orientações Curriculares: expectativas de aprendizagem para Educação de Jovens e Adultos - EJA. São Paulo: SME / DOT, 2008.

1994.100p

Secretaria Municipal de Educação. Encontro - PROALFA - Orientações Básicas.

Secretaria Municipal de Educação. Itinerário Formativo. Auxiliar de Serviços Gerais. Pequenos Reparos. Módulo II. São Paulo, 2003.

. Secretaria Municipal de Educação. Reestruturação e Reorientação Curricular da Educação de Jovens e Adultos. Primeiro e Segundo Segmento do Ensino Fundamental. São Paulo, 2003.

. Secretaria Municipal de Educação. Relatório dos Primeiros Seis Meses de Gestão de José Aristodemo Pinotti. São Paulo, 2005. Disponível em:<http://portalsme.prefeitura.sp.gov.br/Projetos/memoria/Documentos/Arquivos/20052008S ME/Relatorioprim6meses.pdf > Acesso em 15 fev. 2012.

Adultos, 1998.

Secretaria Municipal de Educação. Reorganização da EJA - Educação de Jovens e

- Secretaria Municipal de Educação. Revista do CIEJA.Diferentes olhares sobre a prática curricular no CIEJA. São Paulo, 2004.

. Secretaria Municipal de Educação. Revista EducAção No 03, fev. 2003

- Secretaria Municipal de Educação. Traçando o perfil de alunos e professores da EJA. Coleção Uma nova EJA para São Paulo. Caderno 3. São Paulo: Divisão de Orientação Técnica da Educação de Jovens e Adultos - DOT/EJA e ONG Ação Educativa, 2004.

.Secretaria Municipal de Educação. UNESP. CEMES. Unidade de estudo 08. Português. São Paulo, 2000.

. Secretaria Municipal de Planejamento. Globalização e Desenvolvimento Urbano, São Paulo, 2000. 


\section{APÊNDICE A - Quadros de Confluências entre os Fluxos da Política, dos Problemas e das Soluções}

Quadro 1 - A confluência dos fluxos na Gestão Erundina (PT) - 1989-1992

\begin{tabular}{|c|c|c|}
\hline \multicolumn{3}{|c|}{ Gestão de Luíza Erundina (PT) 1989-1992 } \\
\hline Problemas & Soluções & Política \\
\hline $\begin{array}{l}\text { > Indicadores } \\
\text { Grande demanda de pessoas não } \\
\text { alfabetizadas ou com escolaridade } \\
\text { incompleta; índices de evasão e } \\
\text { aprovação da EJA; perfil do estudante e } \\
\text { do professor. } \\
>\text { Apontamento de problemas pelas } \\
\text { escolas }\end{array}$ & $\begin{array}{l}\text { Fontes: Experiências dos Movimentos de } \\
\text { Cultura Popular; Frente do Funcionalismo; } \\
\text { Projetos Especiais das EMEFs. }\end{array}$ & $\begin{array}{l}\text { "Feedback" das políticas } \\
\text { anteriores }\end{array}$ \\
\hline Organizacionais & Organizacionais & Clima Nacional (C.F. \\
\hline $\begin{array}{l}\text { Rigidez de horários; fragmentação das } \\
\text { disciplinas; falta dos professores; } \\
\text { merenda escolar. }\end{array}$ & $\begin{array}{l}\text { Flexibilidade de horários; polivalência e/ou } \\
\text { dupla docência; professor volante; aulas } \\
\text { duplas ou triplas; formação docente; } \\
\text { redução de alunos/turma }\end{array}$ & 1988) \\
\hline Estruturais & Estruturais & Comunidades Políticas \\
\hline $\begin{array}{l}\text { Carga horária; organização curricular; } \\
\text { periodização do ano letivo; repetência e } \\
\text { abandono }\end{array}$ & $\begin{array}{l}\text { Mudança na distribuição da carga horária; } \\
\text { integração de componentes curriculares; } \\
\text { semestralidade; avaliação por conceito; } \\
\text { gestão democrática. }\end{array}$ & $\begin{array}{l}\text { (Paradgma da Educação } \\
\text { Popular - Paulo Freire e } \\
\text { Vera Barreto) }\end{array}$ \\
\hline Metodológicas & Metodológicas & Criação do MOVA \\
\hline $\begin{array}{l}\text { Currículo; dificuldades de ensino- } \\
\text { aprendizagem; relação entre aluno, } \\
\text { professor e escola; falta de } \\
\text { planejamento integrado; distância do } \\
\text { mundo do trabalho. }\end{array}$ & $\begin{array}{l}\text { Planos de aula coletivos; reagrupamento de } \\
\text { alunos; interdisciplinaridade; tema gerador; } \\
\text { atendimento personalizado (plantão de } \\
\text { dúvidas); atividades em espaços educativos } \\
\text { diversificados; articulação com o trabalho. }\end{array}$ & $\begin{array}{l}\text { Diversificação da oferta } \\
\text { de EJA }\end{array}$ \\
\hline
\end{tabular}

Quadro 2 - A confluência dos fluxos na Gestão Maluf (PT) - 1993-1996

\begin{tabular}{|l|l|l|}
\hline \multicolumn{2}{|c|}{ Gestão de Paulo Maluf/ Celso Pitta (PFL) 1993 -2000 } \\
\hline Problemas & Soluçães & Política \\
>Indicadores & Qualidade Total & \\
Índices de reprovação e evasão & Plena utilização de recursos & \\
$\begin{array}{l}\text { Qualidade } \\
\text { >Problemas nas escolas }\end{array}$ & Normatização administrativa & Mudança de governo \\
Estruturais & Módulos de Aprendizagem; Unidades de & Financiamento \\
Ensino presencial; grupos-salas. & Estudo (por disciplinas) \\
Organizacionais & Ensino individualizado e à distância & \\
Rigidez de horários & Avaliação de conteúdos e ensino EJA \\
Metodológicas & dirigido & \\
\hline $\begin{array}{l}\text { Diversidade de projetos; formação de } \\
\text { professores; necessidade de preparar para o } \\
\text { mercado de trabalho; avaliação }\end{array}$ & & \\
\hline
\end{tabular}




\begin{tabular}{|c|c|c|}
\hline \multicolumn{3}{|c|}{ CIEJAs - gestão de Marta Suplicy (PT) - 2001 a 2004} \\
\hline Problemas & Alternativas & Política \\
\hline $\begin{array}{l}\text { >Indicadores } \\
\text { Demanda, evasão, reprovação; } \\
\text { perfil do estudante, professor e } \\
\text { centro. } \\
\text { Feedback: sindicatos, entidades do } \\
\text { MOVA, ONGs. }\end{array}$ & $\begin{array}{l}\text { Fontes: ONGs e Acadêmicos (NAEs), } \\
\text { Experiências dos movimentos de cultura } \\
\text { popular, SENAC-SP. }\end{array}$ & Feedbck das políticas anteriores; \\
\hline$\underline{\text { Organizacionais }}$ & $\underline{\text { Organizacionais }}$ & \\
\hline $\begin{array}{l}\text { Atendimento } \\
\text { ausência de } \\
\text { docente. }\end{array}$ & $\begin{array}{l}\text { Flexibilidade de horários; dupla docência, } \\
\text { "professor volante", aulas duplas ou triplas, } \\
\text { reorganização do trabalho docente e formação } \\
\text { docente. }\end{array}$ & $\begin{array}{l}\text { “Clima Nacional” (LDB 9394/96, Parecer } \\
\text { CNE11/2000, CONFINTEA, 1997, } \\
\text { oposição ao governo FHC). }\end{array}$ \\
\hline Estruturais & $\underline{\text { Estruturais }}$ & Comunidades políticas (SENAC-SP). \\
\hline $\begin{array}{l}\text { Ensino dirigido e à distância. Carga } \\
\text { horária dos cursos, fragmentação } \\
\text { das disciplinas. } \\
\text { Metodológicas } \\
\text { Currículo centrado em transmissão } \\
\text { de conteúdo, avaliação como fator } \\
\text { de exclusão, falta de relação entre } \\
\text { educação e trabalho, dificuldades de } \\
\text { aprendizagem. }\end{array}$ & $\begin{array}{l}\text { Mudanças na distribuição da carga horária das } \\
\text { disciplinas, integração de componentes } \\
\text { curriculares, módulos de aprendizagem. } \\
\text { Metodológicas } \\
\text { Trabalho docente coletivo, ensino presencial, } \\
\text { avaliação por conceito, interdisciplinaridade, } \\
\text { "Oficinas de Estudos" articulação entre } \\
\text { "mundo da cultura" e "mundo do trabalho", } \\
\text { atividades em espaços educativos fora das } \\
\text { escolas. }\end{array}$ & \\
\hline
\end{tabular}

Quadro 3- Confluência dos fluxos na gestão de Marta Suplicy (2001-2004)

Quadro 4- Confluência dos fluxos na gestão de José Serra/ Gilberto Kassab (2005-2009)

\begin{tabular}{|c|c|c|}
\hline \multicolumn{3}{|c|}{ Gestão de José Serra/Gillberto Kassab (PSDB- DEM) 2005 -2009 } \\
\hline Problemas & Alternativas & Política \\
\hline $\begin{array}{l}\text { > Indicadores } \\
\text { Demanda, evasão e reprovação. } \\
\text { "Feedback" de sindicatos, ONGs. } \\
\text { Qualidade }\end{array}$ & & $\begin{array}{l}\text { "Feedback de políticas } \\
\text { anteriores }\end{array}$ \\
\hline$\underline{\text { Organizacionais }}$ & Organizacionais & Nacional" \\
\hline $\begin{array}{l}\text { Itinerários } \quad \text { Formativos; } \quad \text { trabalho } \\
\text { docente; relação de alunos/turma. }\end{array}$ & $\begin{array}{l}\text { Flexibilidade de horários; "Orientações de } \\
\text { Estudos"; atendimento "uniforme" em } \\
\text { todos os dias da semana; rearranjo dos } \\
\text { horários de trabalho coletivo (JEIF) }\end{array}$ & (FUNDEB) \\
\hline Estruturais & Estruturais & Comunidades políticas \\
\hline $\begin{array}{l}\text { Carga horária das disciplinas; atribuição } \\
\text { de aulas; organização dos dias letivos; } \\
\text { semestralidade; falta de "unidade" com } \\
\text { a rede }\end{array}$ & $\begin{array}{l}\text { Mudanças na atribuição da carga horária } \\
\text { das disciplinas; Itinerário Formativo em } \\
\text { Informática e Mídias (Nas Ondas do Rádio); } \\
\text { processo seletivo docente; definição de } \\
\text { quadro pessoal. }\end{array}$ & (sindicato \\
\hline Metodológic & Metodológicas & \\
\hline Avaliação & "Expectativas de aprendizagem" & \\
\hline
\end{tabular}




\section{APÊNDICE B - Roteiros de Entrevista}

Roteiro de Entrevista para Profissionais da SME:

A- Marisa Darezzo - DOT EJA- gestão Marta Suplicy,

B- Romy Schinzare - DOT EJA - Gestão Gilberto Kassab

C - Célia Borges, Êda Luiz, Roseli Pereira - Equipes dos CIEJAs

1) Início- apresentação breve da entrevistadora e pesquisa.

2) Solicitar apresentação do entrevistado. (Para: A,B,C)

Conte um pouco de sua trajetória profissional na EJA e atuação no CIEJA.

3) Como descreveria o Projeto CIEJA entre as demais ações para EJA na cidade? (Para: A,B,C)

4) Como foi a elaboração dos Itinerários Formativos de Qualificação Profissional? (Para: $\mathrm{A}, \mathrm{B}, \mathrm{C})$

5) Como se chegou à decisão de finalizar o convênio dos CIEJAs com o SENAC - SP / Quais seus efeitos nos Centros? (Para A e C)

6) O que motivou e como foi elaborada a proposta de Reorganização da EJA? (Para B e C)

4.1 Houve alguma participação das equipes pedagógicas dos CIEJAs nesse processo? Como ela se realizou? (caso não tenha sido abordado anteriormente)

7) Quais foram as principais orientações dessa Reorganização para os CIEJAs? E como foram recebidas essas orientações nos Centros? (Para B e C)

8) Por que e como foi elaborado o Novo Projeto CIEJA? (Para B e C)

8.1 Houve alguma participação das equipes pedagógicas dos CIEJAs nesse processo? Como ela se realizou? (caso não tenha sido abordado anteriormente)

9) Como você avaliaria o Projeto CIEJA? Quais seriam seus avanços e dificuldades para melhoria do atendimento aos estudantes? (Para A, B e C).

\section{$\underline{\text { Roteiro de Entrevista para profissional do SENAC- SP, Maria Teresa Nori }}$}

1) Início- apresentação breve da entrevistadora e pesquisa

2) Conte um pouco de sua trajetória profissional na educação e como foi seu trabalho no

Projeto CIEJA?

3) Como foi o contato e realização do convênio com SENAC e Prefeitura?

4) Quais eram os objetivos do convênio e responsabilidades do SENAC?

5) Os Itinerários Formativos - cursos já existiam no SENAC? Como foram elaborados?

6) Como eram contratados os monitores e como eram formados?

7)Como era a formação dos professores do CIEJA?

8) Por que o convênio foi extinto?

9) Quais foram os maiores facilitadores e desafios no convênio? 


\section{APÊNDICE C - Exemplo de autorização para utilização de dados coletados em entrevistas.}

TERMO DE CONSENTIMENTO LIVRE E ESCLARECIOO

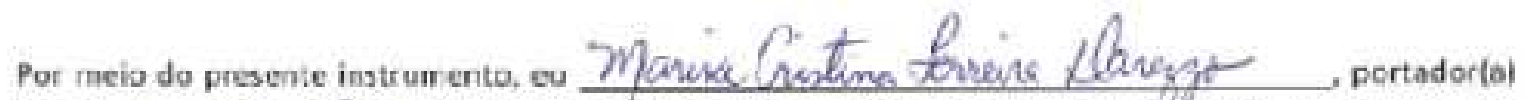

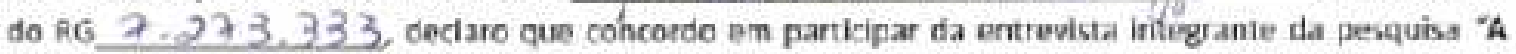
fermaça do Projeto CIEJA: o papel dos atores locais", do Programa de Pds-graduaça em Educaça da Universidade de Sāo Paulo, cuja pesquisadora Vancssa Elsas Porfirie de Faria e arientada peta Profa. Dra. Mana Clara Di Pierio.

A pesquisa tem cemo objetivos sistematitar a historia de formaço do Projeto CIE⿺A, analisar a participaç̃o des atores lacals na formaço do Projeto e avaliar as influências decorrentes das politicas municipais de EIA entre diferentes gestōes.

A metodologie prevê a realizegão de eritrevistas com integrantes dos Gupos de Trabalho que participaram da formaça do Projeto CIEA para análise da atuaça dos atores Iocais na confliguraça do raferido Projeto.

Tenho a ciéncia de que a entrevista realizada serd́d gravada e transcrita para sua posterior análise no estuda, sendo seus dados tratados de acordo com as normas do Comitê de Ética na Pesquisa da FEUSP, considerando-se que nso há riscos previsiveis decorrentes de minha participsȩäo.

Foi me informado que a qualquer tempo poderei solicitar maiores esclarecimentos sobre a pesquisa ou usos de minha entrevista, sendo earantido que poderei recusor ou desstir de partiosar dela a cualquer momento antes da defesa di disscrtoçio, scm que iste acarrete em quaiquer penalidade ou prejuizo, devendo, para tanto apenas contatar a pesq̨uisadora responsivel através de e-mail ou telefone abaixo informados

Apbs ter sido escla recido pela pesquisadora e tendo compreendicio os temos em que se realiza a pesquisa, consinto am participar da citada pesquisa, fornecendo entrevista.
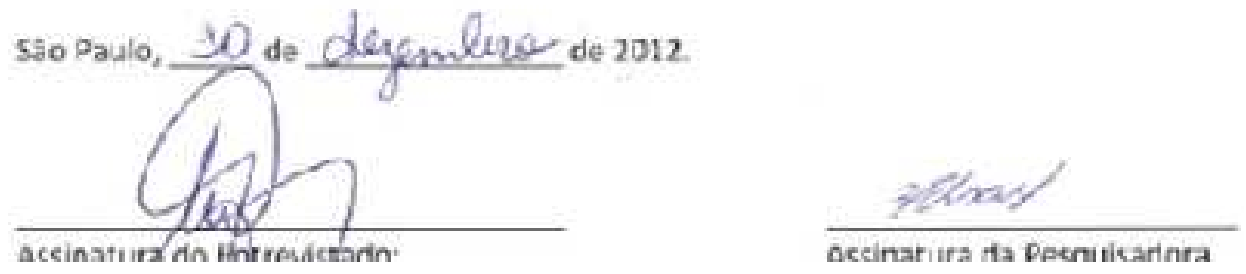
ANEXO A - Modelo das apostilas dos CEMES "Unidade de Estudos"

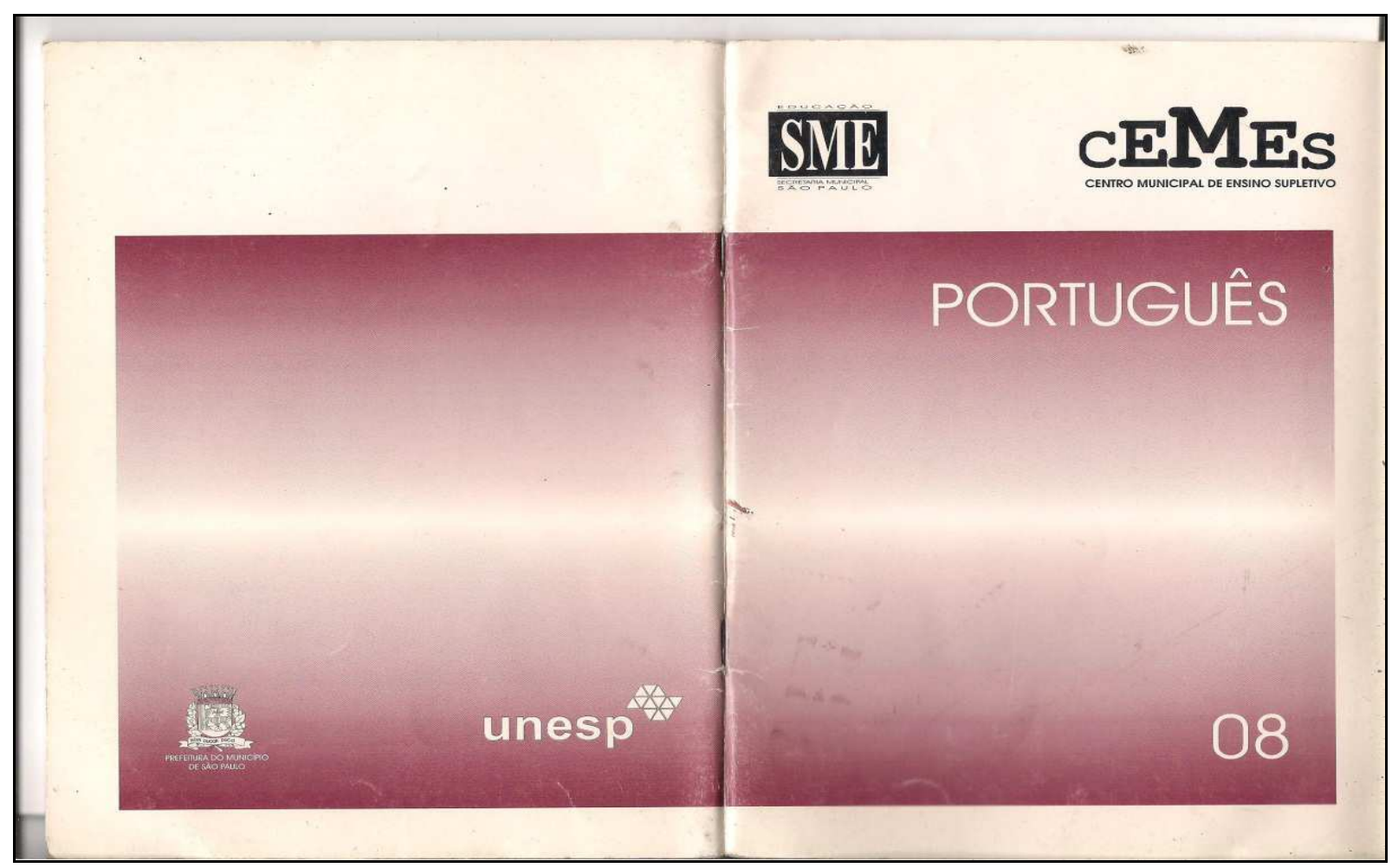

EQUIPES DE TRABALHO DA UNESP

Coordenaçáo Geral Prot. Dr. Romualdo Dias

Fagupe de Ciencias - 1 uiz M. do Carvalbo coord Katia G. Roselli. Mancos Serzedello. Maria fo Campos, María M.P.L. GumeMaria S C. Morini, Rscando Trabeu Santori.

Equipe de Lingax Portagessa-Odetie G. A

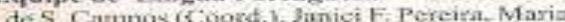
- de R. Rampos Maried T Roso, Rubues D Maia.

Equipe de Histúria - Maria C.S Di Creddes (Coord,). Carlos R Oliveira. Paito Alwes.

Equipe de ingtes Dirve C. Monteino, (Eoond.y. Denise M. A L Limis.

Equipe de Foducasăo Artística - Regina C.C.S. pinto (Coord) Anderson L. F Brandấ, Misriu R. N Campos.

Equipe ste Ceorgrafia - Rosângela D. Almeida

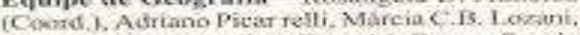
Maria BSS. Carvatho Rasa M Brym, Seruic L. Marandic. Watquiria da C.A. Troppmair.

Eatripe de Fducaçāo Fisica - Marì Aporecida Melo. Deruglas N paricitio de campos.

Equipe de Matematica Anionis $C, C$ Souza (Coord) Cackes A Francisco, Elavio Trombim

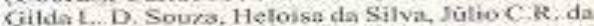
Silva Luciara C M 12zi Marco A. Escher Nadir

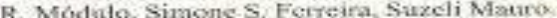

Equipe Módule II-Franetseo Jose Carvaliho Mazrou (Coord Aderril Lores Adtriane Cristina Mero Sellan A gostinho Tisdeu de Figuciredo Menterra Alda Justegeins Marit, Fusúno Maris Me Franca Rumos, Eqhice Martin Ritsmeister Mareil Marie Apurecida Mello Maria Folanda

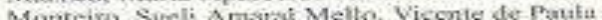
Morriterv, sitet:

\section{Competaç̃o Cirăfliciaz}

Huipe do CLAPIA

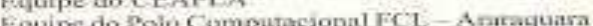
Aquipe do folo Colera (Xrea Extensao F(: L)

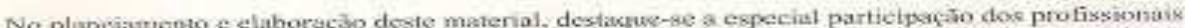
Nares, da Divisto de Orientacibo Teonica-DO'

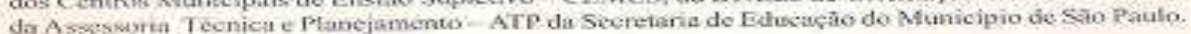




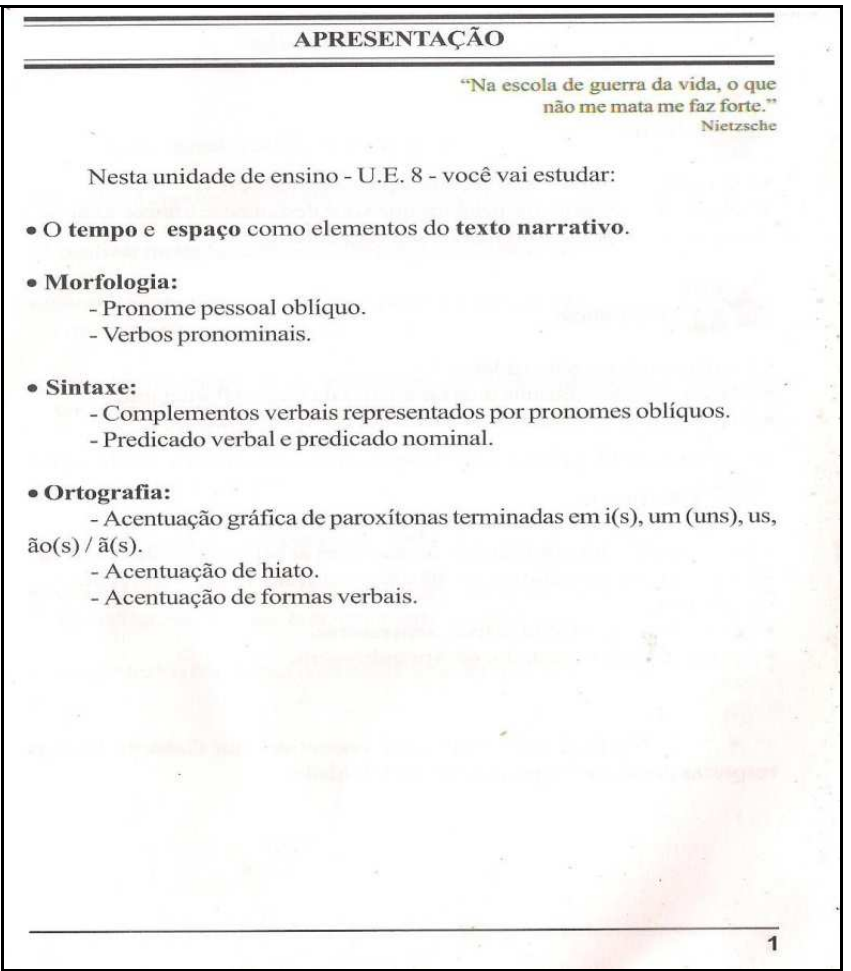

Português Volume 8

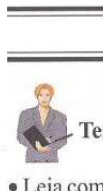

政o e releia para resolver as questões.

- Procure no dicionário as palavras que você desconhece e anote-as no seu caderno. Essa prática ampliará o seu vocabulário.

\section{\%ํ. Gramática:}

- Faça os exercícios no caderno

- Se tiver dúvidas, consulte uma Gramática da Língua Portuguesa.

- Se precisar, converse com o Orientador de Aprendizagem.

\section{Redação:}

- Faça o texto num rascunho, de acordo com as orientações da proposta.

- Leia seu texto e verifique se está claro e correto. Faça as correções necessárias.

- Passe a limpo com letra legivel, sem rasuras.

- Apresente-o ao Orientador de Aprendizagem.

- $\quad$ No final desta U.E. você encontrará um Gabarito com as respostas das questões propostas nas Atividades.
Volume 8

\section{OBJETIVOS ESPECÍFICOS}

Após o estudo da U.E. 8 você deverá ser capaz de:

- Perceber a importância do tempo e do espaço como elementos da narrativa.

- Localizar no texto as referências temporais e espaciais .

- Identificar em texto os pronomes pessoais oblíquos e sua função sintática como complementos verbais.

- Usar corretamente esses pronomes em substituição a nomes e na conjugação de verbos pronominais.

- Reconhecer o predicado verbal e o predicado nominal,distinguindo seus núcleos e sua estrutura.

- Construir orações com predicado verbal e predicado nominal.

- Acentuar corretamente as palavras paroxítonas, os hiatos e as formas dos verbos ter, vir, ver, ler, crer, dar e seus derivados.

- Redigir textos narrativos com referências temporais e espaciais. 
ANEXO B - Modelo das apostilas de Itinerário Formativo dos CIEJAs

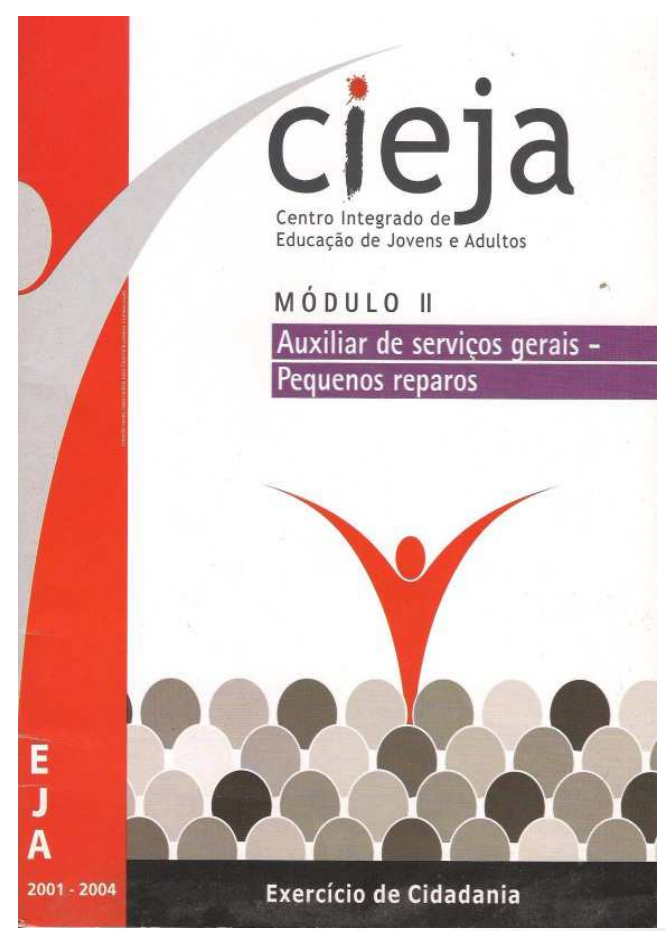

Itinerário Formativo de Serviços Domiciliares Módulo II

Auxiliar de serviços gerais - Pequenos reparos

SENAC-SP
Presidente: Abram Szajman

Diretor Regional: Luiz Francisco de Assis Salgado

Superintendência de Desenvolvimento: Luiz Carlos Dourado

Centro de Tecnologia e Gestão Educacional - CTE/SENAC-SP

Gerente Corporativo: Ulisses Defonso Matanó

Coordenação de edição

Cecilia Reggiani Lopes

Elaboração

Marinilzes Moradillo Mello

Nivia Gordo

Revisão pedagógica

Judite Dare

Revisão técnica

Marcos Robson Lima da Costa

Validação

Equipe DOT/EJA

(Pq. Bristol); 2 (Vila Sabrina); 2 (Mandaqui); 3 (Brasilândia); 6 (Jd. Consórcio); 11 (Guainases)

Projeto gráfico

Eduardo Okuno

Mauricio Negro

llustraçōes

Avelino Guedes

Apoio

André Mendonça da Silva - CTE/SENAC-SP

São Paulo

São Paulo
Janeiro de 2003 


\section{ANEXO C - Jornal do SINPEEM}

Jornal do Sinpeem, setembro de 2008 - Ano 12- ${ }^{\circ} 103$, p. 8 .

\section{SINPEEM na luta pela EJA}

O SINPEEM reivindicou à SME que os professores que atuam na Educação de Jovens e Adultos (EJA) nas unidades que tiveram redução de turmas, por conclusão do $4^{\circ}$ termo, e não-abertura de novas turmas no segundo semestre, sejam mantidos nas jornadas em que se encontram, respeitando o seu turno de trabalho e na própria unidade de trabalho.

Nossa reivindicação considera que a redução de salas/aulas se deve à mudança da grade e organização da EJA, por decisão da

SME e para evitar perda de remuneração e impossibilidade de acúmulo dos professores que tiverem perda de aulas.

Portanto, aplicando-se o parágrafo $1^{\circ}$ do art. 15 da Lei $\mathrm{n}^{\circ} 14.660$ 07 - que permite a inclusão em Jeif, mesmo quando não houver classe ou a quantidade mínima exigida , poderia ser garantida a permanência deste professor na jornada de opção sem a necessidade de participar de escolha/atribuição nas DREs para completar a Jornada Especial Integral de Formação.

\section{Sindicato defende a grade curricular anterior e a ampliação do atendimento}

A nova grade curricular de EJA causou problemas que indicam a necessidade de mudanças urgentes. Redução do número de aulas, maior dificuldade para composição de jornadas e horários para os professores. Já os alunos, além da redução do número de aulas, reclamam pelo fato de as aulas de orientação de estudos não terem criado, na maioria das unidades, uma situação melhor para a aprendizagem.

O SINPEEM defende a volta da grade curricular anterior e a ampliação do atendimento, garantindo vagas na EJA para todos que a procurarem.

\section{CONVENIOS COM UNIVERSIDADES}

Centro Universitário Sant'Anna (Uni Sant'Anna) fone 2175-8040, site www.unisantanna.br/pac

Faculdade Impacta Tecnologia (FIT) - rua Árabe, 71, Vila Clementino, fone 5589-2666, site www.impacta.edu.br

Faculdade Guaianás - fone 6557-9352,

site: www.facul dadeguaianas.com.br

Faculdade Sumaré - rua Capote Valente, 1.121, Sumaré, fones 3067-7999 e 0800-55-1121, site www.facsumare.com.br

Universidade Braz Cubas (UBC) - fone 4791-8213,

site www.brazcubas.br

Universidade de Mogi das Cruzes (UMC) - fone 4798-7000, site www.umc.br

Universidade Bandeirantes (Uniban) - fone 6967-9000, site www.uniban.br

Faculdade Integração Zona Oeste (Fizo) - fone 0800-104242, site www.fizo.edu.br

Centro Universitário Capital (Unicapital) - avenida Paes de Barros, 2.883, Mooca - fone 6165-1000, site www.unicapital.edu.br

Centro Universitário Assunção (Unifai) - unidades: Ipiranga: avenida Nazaré, 993, Ipiranga, fone 6166-8555; Santana: rua Voluntários da Pátria, 1.653, fone 6221-8810; Vila Mariana: rua Afonso Celso, 711 (próximo à Estação Santa Cruz do Metrô), fone 5087-0199, site www.unifai.edu.br

Centro Universitário Nove de Julho (Uninove) - fone 6633-9000, site http://portal.uninove.br

8 Faculdade Método de São Paulo (Famesp) - avenida Jabaquara 1.314, Metrô Saúde, fone 5587-5700, site www.famesp.edu.br

Instituto Nacional de Pós-Graduação (INPG) -

avenida das Nações Unidas, 12.995, fone 3095-8400,

e-mail atendimento@inpg.com.br, site www.inpg.com.br

\section{SME rejeita proposta}

Ainda em junho, quando apresentamos esta reivindicação, a SME disse que estudaria seu impacto, para responder se nos atenderia ou não. Realizados os estudos, a SME respondeu que atender ao que reivindicamos implicaria em deixar escolas sem professores, tendo outros em JEI fora da regência e em CJ.

Afirmou, também, que garantir aos professores que perderem aulas de EJA que permaneçam em $\mathrm{CJ}$, tendo a garantia de Jeif, criaria uma situação de quebra de isonomia, na qual outros professores do regular, para completarem a Jeif, tiveram de assumir aulas em duas ou mais unidades, no início do ano e passariam a exigir igualdade de tratamento e de direitos.

0 SINPEEM não concordou com os argumentos, insistiu na excep cionalidade do momento e do encerramento do $4^{\circ}$ termo. Mesmo as sim, a SME manteve o seu posicionamento.

\section{Para obter informações detalhadas sobre ações judiciais

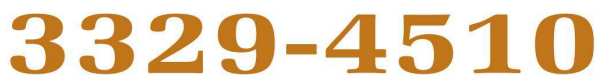 seuprocesso@sinpeem.com.br}


Jornal do Sinpeem, dezembro de 2008 - Ano 12- n 104, p.20.

\section{SINPEEM participa de audiência pública sobre o orçamento de 2009}

Em 17 de novembro, o SINPEEM participou de audiência pública na Câmara Municipal sobre o orçamento de 2009. Além de vereadores, também estavam presentes representantes de outros sindicatos e de organizações sociais, como a Ação Educativa, Fórum de Educação da Zona Leste e Movimento Creche para Todos.

O secretário municipal de Educação, Alexandre Schneider, anunciou as prioridades de sua pasta, ficando clara a expansão do atendimento às crianças de zero a três anos de idade em creches conveniadas. Afirmou que construirá cerca de 30 Emeis, dará continuidade às iniciativas para eliminar o denominado "turno da fome" e a intenção de entregar o leite através dos Correios.

Durante a audiência nos posicionamos, contestando as diretrizes da SME. Defendemos que a ampliação da rede direta deve ter como finalidade a redução do número de alunos por sala de aula. Apontamos a necessidade de logística material, recursos humanos adequado e formação ne- cessária, reorganização do currículo, in centivo e valorização aos projetos de trabalho que tenham como objetivo a qualidade de ensino.

Estamos certos de que, com os recursos existentes e a volta da aplicação de $30 \%$ na manutenção e desenvolvimento do ensino, que exigimos, a Prefeitura pode entregar unidades escolares com total condições de funcionamento, infra-estrutura e material humano, didático e pedagógico necessários.

\section{Sindicato integra a Comissão Executiva \\ que discute \\ Plano Municipal de Educação}

Apesar de estar disposto na Lei Orgânica do Município de São Paulo como exigência para o sistema de ensino, até hoje a cidade de São Paulo não tem seu Plano Municipal de Educação (PME).

Desde a aprovação da referida lei já se passaram cinco governos, sem que o PME ganhasse pelo menos mais espaço nas discussões para elaboração de uma proposta fixe diretrizes e metas para a educação da cidade.

Para o SINPEEM, a elaboração do PME, aprovado depois de ampla discussão, na sociedade, deve considerar a necessidade de contribuir com um novo modelo de educação que se apoie sobre bases coletivas e solidárias, novas formas de desenvolvimento do tempo de trabalho e fixação das respon-

sabilidades, tanto dos governos como da sociedade.

O sindicato está participando do Fórum constituído, que se reúne na SME.

Como entidade representativa dos profissionais de educação e defensora da escola pública, gratuita, laica, para todos, participaremos da Comissão Executiva e promoveremos debates com a categoria e a sociedade.

\section{Alunos da rede municipal farão a Prova São Paulo em dezembro}

Secretaria concorda com a volta da grade e anualidade da Educação de Jovens e Adultos

A Secretaria Municipal de Educação publicou em 18 de novembro a Portaria $n^{\circ}$ 4.618, que dispõe sobre a organização das escolas para 2009, ratificando a conquista do SINPEEM com a volta da grade anterior da Educação de Jovens e Adultos (EJA), o que significa:

$\checkmark$ carga horária de 25 horas/aula semanais para o aluno (cinco horas) aula diárias, com duração de 45 minutos cada);

$\checkmark$ fim das horas/aula de orientação;

$\checkmark$ mesma quantidade de aulas por disciplina.

Outra reivindicação do SINPEEM atendida pela SME diz respeito ao atendimento à EJA nas Emefs, Emefms e Emees, que passa a ser anual, dividido em quatro etapas (alfabetização, básica, complementar e final), cada uma com carga horária mínima de 800 horas, distribuídas, no mínimo, em 200 dias de efetivo trabalho escolar.
Vale lembrar que desde que a grade curricular da EJA foi alterada, o SINPEEM vinha apontando e insistindo com a SME para que reconhecesse os problemas que passaram a existir com as mudanças na grade da EJA, tanto para os alunos como para a organização das escolas.

\section{SINPEEM conquista comissão}

Na reunião para debater a concepção e organização e expansão do atendimento da EJA com o presidente do SINPEEM, Claudio Fonseca, o secretário municipal de Educação, Alexandre Schneider, se comprometeu em constituir uma comissão integrada pelo SINPEEM e a SME, para desenvolver e realizar campanha de divulgação pela ampliação das inscrições e abertura de mais salas de EJA. Afirmou, também, que outra comissão será formada para apresentar proposta pedagógica, formação profissional e organização da EJA, a ser concluída até o segundo semestre de 2009.
A Secretaria Municipal de Educação publicou no DOC de 26 de novembro a Portaria $n^{\circ} 4.689$, que dispõe sobre a realização da Prova São Paulo 2008, em todas as unidades educacionais de ensino fundamental regular. As avaliações de Língua Portuguesa e de Matemática serão aplicadas nos dias 10 e 11 de dezembro de 2008

As provas terão três horas de duração cada. São destinadas a todos os alunos matriculados nos segundos e quartos anos do ciclo I, terceiros e quartos anos -PIC - e segundos anos do ciclo II do ensino fundamental regular da rede municipal de ensino, dos terceiros anos do ciclo I, primeiros, terceiros e quartos anos do ciclo II (por amostragem, definida por sorteio feito entre 35 alunos de cada ano), além dos alunos dos primeiros anos do ciclo II que tiveram desempenho abaixo de 150, na escala de Língua Portuguesa, na Prova São Paulo 2007

Segundo a Portaria, também serão feitos levantamentos de dados dos fatores associados ao desempenho dos alunos, mediante aplicação de questionários aos professores, coordenadores pedagógicos, diretores e supervisores escolares.

A Portaria, a Prova São Paulo 2008 será aplicada por professores da própria unidade educacional. 


\section{ANEXO D - Diretrizes para o funcionamento dos Centros Integrados de Educação de Jovens e Adultos}

LEI N 15.648, DE 14 DE NOVEMBRO DE 2012

(Projeto de Lei n ${ }^{\circ}$ 133/10, do Vereador Gilson Barreto - PSDB)

Estabelece diretrizes para o funcionamento dos Centros Integrados de Educação de Jovens e Adultos - CIEJAs na Rede Municipal de Ensino do Município de São Paulo.

GILBERTO KASSAB, Prefeito do Município de São Paulo, no uso das atribuições que lhe são conferidas por lei, faz saber que a Câmara Municipal, em sessão de 31 de outubro de 2012, decretou e eu promulgo a seguinte lei:

Art. $1^{\circ} \mathrm{O}$ Poder Público Municipal, por meio dos órgãos competentes, observará as diretrizes constantes desta lei para o funcionamento dos Centros Integrados de Educação de Jovens e Adultos - CIEJAs, na Rede Municipal de Ensino do Município de São Paulo.

Art. $2^{\circ}$ Os Centros Integrados de Educação de Jovens e Adultos - CIEJAs estarão diretamente vinculados às Diretorias Regionais de Educação da Secretaria Municipal de Educação.

Art. $3^{\circ}$ Os Centros Integrados de Educação de Jovens e Adultos - CIEJAs deverão promover cursos de Ensino Fundamental, que poderão estar articulados com cursos e programas de formação inicial e continuada de trabalhadores, em consonância com as diretrizes da política educacional da Secretaria Municipal de Educação.

Parágrafo único. Os cursos e programas de formação inicial e continuada de trabalhadores poderão ser desenvolvidos mediante convênios ou acordos com empresas e entidades, públicas ou privadas.

Art. $4^{\circ}$ A Secretaria Municipal de Educação proverá, mediante critérios a serem fixados em regulamento, os recursos humanos necessários ao pleno funcionamento dos Centros Integrados de Educação de Jovens e Adultos CIEJAs, bem como os servidores administrativos e operacionais.

Art. $5^{\circ}$ A supervisão e o acompanhamento administrativo e pedagógico dos Centros Integrados de Educação de Jovens e Adultos - CIEJAs caberão à Secretaria Municipal de Educação, por meio das respectivas Diretorias Regionais de Educação, sob a coordenação e orientação da Diretoria de Orientação Técnica da Secretaria Municipal de Educação.

Art. $6^{\circ} \mathrm{O}$ Executivo regulamentará a presente lei no prazo de 90 (noventa) dias, a contar da sua publicação.

Art. $7^{\circ}$ As despesas decorrentes da execução desta lei correrão por conta das dotações orçamentárias próprias, suplementadas se necessário.

Art. $8^{\circ}$ Esta lei entrará em vigor na data de sua publicação, revogadas as disposições em contrário.

PREFEITURA DO MUNICÍPIO DE SÃO PAULO, aos 14 de novembro de $2012,459^{\circ}$ da fundação de São Paulo.

GILBERTO KASSAB, PREFEITO

NELSON HERVEY COSTA, Secretário do Governo Municipal

Publicada na Secretaria do Governo Municipal, em 14 de novembro de 2012. 
ANEXO E - Cria os Centros Integrados de Educação de Jovens e Adultos - CIEJAs.

DECRETO No 43.052, DE 4 DE ABRIL DE 2003

Cria os Centros Integrados de Educação de Jovens e Adultos - CIEJAs.

MARTA SUPLICY, Prefeita do Município de São Paulo, no uso das atribuições que lhe são conferidas por lei,

CONSIDERANDO as diretrizes da política educacional adotada pela Secretaria Municipal de Educação, consubstanciadas na democratização do acesso e da permanência, democratização da gestão e qualidade social da educação;

CONSIDERANDO a necessidade de ampliar-se o acesso ao ensino fundamental dos jovens e adultos que não tiveram oportunidade de cursá-lo e concluí-lo na idade própria, assim como de implantar-se programas de educação especialmente dirigidos a esses educandos, com ênfase na preparação para o mundo da cultura e na orientação para o mundo do trabalho;

CONSIDERANDO, por fim, o parecer CME $\mathrm{n}^{\circ}$ 10/02, do Conselho Municipal de Educação, aprovado em 7 de novembro de 2002, que autorizou o funcionamento dos Centros Integrados de Educação de Jovens e Adultos - CIEJAs,

D E C R E T A:

Art. $1^{\circ}$. Ficam criados os Centros Integrados de Educação de Jovens e Adultos - CIEJAs, diretamente vinculados aos Núcleos de Ação Educativa - NAEs, da Secretaria Municipal de Educação.

Art. $2^{\circ}$. Os Centros Integrados de Educação de Jovens e Adultos promoverão cursos de ensino fundamental, articulados com a educação profissional de nível básico, atendidos os interesses da comunidade e as peculiaridades locais.

$\S 1^{\circ}$. Os cursos serão organizados em dois ciclos, compostos por quatro módulos, e desenvolvidos em oito semestres.

$\S 2^{\circ}$. A educação profissional de nível básico poderá ser desenvolvida mediante convênios ou acordos com empresas e entidades, públicas ou privadas.

Art. $3^{\circ}$. A supervisão e o acompanhamento técnico-administrativo e pedagógico dos Centros Integrados de Educação de Jovens e Adultos caberão à Secretaria Municipal de Educação, por meio dos Núcleos de Ação Educativa - NAEs, sob a coordenação e orientação da Diretoria de Orientação Técnica - DOT.

Art. $4^{\circ}$. Os Centros Integrados de Educação de Jovens e Adultos serão instalados em prédios municipais, adaptados ou construídos para esse fim, ou em prédios locados ou cedidos por órgãos públicos e entidades particulares, mediante convênios e acordos de cooperação, nos termos da legislação em vigor.

Art. 5 . Para fins de designação de professores do ensino fundamental e demais servidores técnicos, administrativos e operacionais, ficam os Centros Integrados de Educação de Jovens e Adultos equiparados às Unidades Escolares da Rede Municipal de Ensino.

Art. 6 ${ }^{\circ}$. Os atuais Centros Municipais de Ensino Supletivo - CEMEs passam a denominar-se Centros Integrados de Educação de Jovens e Adultos - CIEJAs, que deverão organizar-se e reformular a estrutura de funcionamento dos cursos de acordo com as diretrizes da Secretaria Municipal de Educação e as disposições estabelecidas pelo órgão normativo do Sistema Municipal de Ensino.

Art. $7^{\circ}$. A Secretaria Municipal de Educação, mediante portaria, baixará normas complementares com vistas ao pleno funcionamento dos Centros Integrados de Educação de Jovens e Adultos, dotando-os dos recursos materiais e humanos necessários.

Art. $8^{\circ}$. Os Centros Integrados de Educação de Jovens e Adultos passarão a vincular-se às Coordenadorias de Educação criadas pela Lei $n^{\circ} 13.399$, de $1^{\circ}$ de agosto de 2002, quando forem instaladas, cabendo-lhes a supervisão e o acompanhamento técnico-administrativo e pedagógico dos referidos centros, mantida a coordenação e orientação da Diretoria de Orientação Técnica - DOT, da Secretaria Municipal de Educação.

Art. $9^{\circ}$. As despesas com a execução deste decreto correrão por conta das dotações orçamentárias próprias, suplementadas se necessário.

Art. 10. Este decreto entrará em vigor na data de sua publicação, produzindo efeitos a partir de $1^{\circ}$ de janeiro de 2003 em relação ao disposto no seu artigo $6^{\circ}$, revogados os Decretos $\mathrm{n}^{\circ} 33.894$, de 16 de dezembro de 1993 , $\mathrm{n}^{\circ} 35.456$, de 30 de agosto de 1995 , e n 36.367 , de 6 de setembro de 1996.

PREFEITURA DO MUNICÍPIO DE SÃO PAULO, aos 4 de abril de 2003, 450 da fundação de São Paulo.

MARTA SUPLICY, PREFEITA.

LUIZ TARCISIO TEIXEIRA FERREIRA, Secretário dos Negócios Jurídicos.

JOÃO SAYAD, Secretário de Finanças e Desenvolvimento Econômico. MARIA APARECIDA PEREZ, Secretária Municipal de Educação.

Publicado na Secretaria do Governo Municipal, em 4 de abril de 2003.

RUI GOETHE DA COSTA FALCÃO, Secretário do Governo Municipal 